Coastal and Marine Geology Program

\title{
West Florida Shelf: A Natural Laboratory for the Study of Ocean Acidification
}

With sections on

Surface-Sediment Constituent Data

Sediment Characteristics and Distribution along the West-Central Florida Inner Shelf

Assessing Carbonate and Total Organic Content Trends in Sediments on the West Florida Shelf

West Florida Shelf: A Foraminiferal Perspective Irradiance Data from the West Florida Shelf

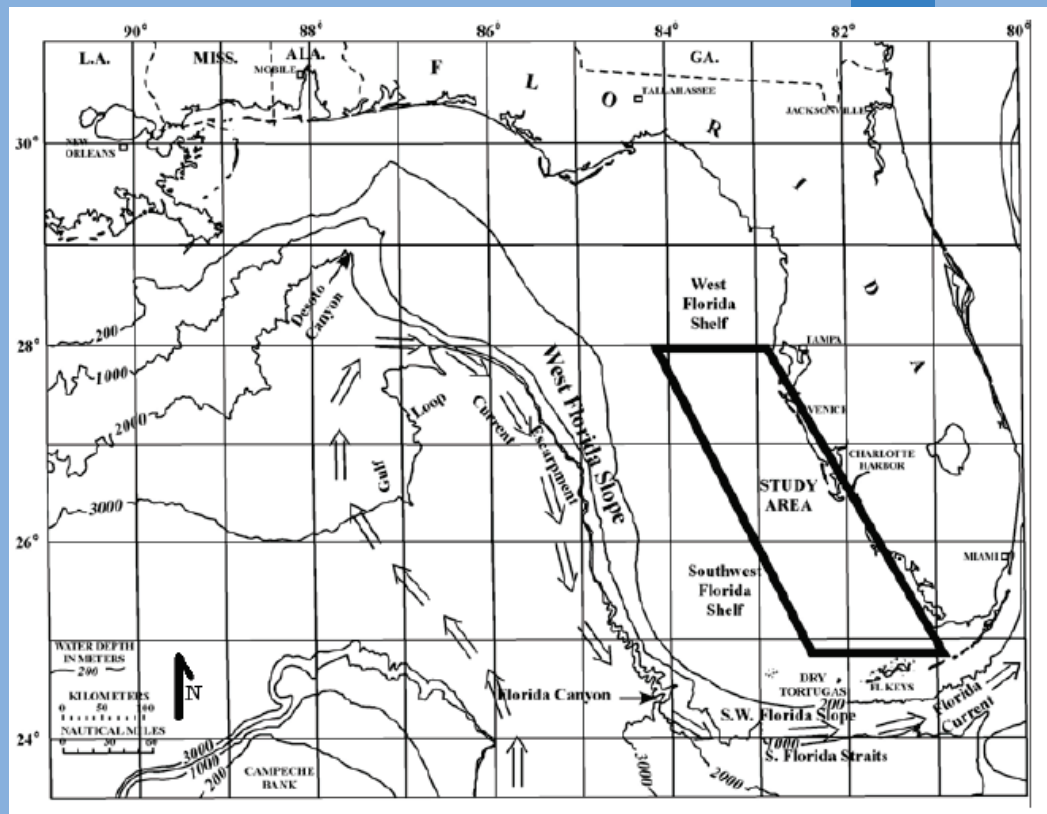

Open-File Report 2010-1134 
Cover: Map of Florida and the Gulf of Mexico showing the study area (modified from Brooks and Holmes, in press; used with permission). 


\section{West Florida Shelf: A Natural Laboratory for the Study of Ocean Acidification}

By Pamela Hallock, ${ }^{1}$ Lisa L. Robbins, ${ }^{2}$ Rebekka Larson, ${ }^{1}$ Tanya Beck, ${ }^{1}$

Patrick Schwing, ${ }^{1}$ Michael Martínez-Colón, ${ }^{1}$ and Brad Gooch ${ }^{1}$

${ }^{1}$ University of South Florida College of Marine Sciences, 140 7th Ave. South, St. Petersburg, FL 33701

${ }^{2}$ U.S. Geological Survey Coastal and Marine Science Center, 600 4th Street South, St. Petersburg, FL 33701

With sections on

Surface-Sediment Constituent Data

By Rebekka Larson ${ }^{1}$

Sediment Characteristics and Distribution along the

West-Central Florida Inner Shelf

By Tanya Beck'

Assessing Carbonate and Total Organic Content Trends in Sediments on the West Florida Shelf

By Patrick Schwing ${ }^{1}$

West Florida Shelf: A Foraminiferal Perspective

By Michael Martínez-Colón ${ }^{1}$

Irradiance Data from the West Florida Shelf

By Brad Gooch ${ }^{1}$

Coastal and Marine Geology Program

Open-File Report 2010-1134

U.S. Department of the Interior

U.S. Geological Survey 


\title{
U.S. Department of the Interior \\ KEN SALAZAR, Secretary \\ U.S. Geological Survey \\ Marcia K. McNutt, Director
}

\section{U.S. Geological Survey, Reston, Virginia: 2010}

\author{
For more information on the USGS — the Federal source for science about the Earth, its natural and living resources, \\ natural hazards, and the environment, visit http://www.usgs.gov or call 1-888-ASK-USGS \\ For an overview of USGS information products, including maps, imagery, and publications, \\ visit http://www.usgs.gov/pubprod \\ To order this and other USGS information products, visit http://store.usgs.gov
}

\begin{abstract}
Any use of trade, product, or firm names is for descriptive purposes only and does not imply endorsement by the U.S. Government.

Although this report is in the public domain, permission must be secured from the individual copyright owners to reproduce any copyrighted materials contained within this report.
\end{abstract}

Suggested citation:

Hallock, Pamela, and others, 2010, West Florida Shelf: A natural laboratory for the study of ocean acidificiation: U.S. Geological Survey Open-File Report 2010-1134, 95 p. 


\section{Preface}

\section{By Pamela Hallock' and Lisa L. Robbins ${ }^{2}$}

In 2007, the United Nations' Intergovernmental Panel on Climate Change (IPCC) released its updated synthesis of climate change research, analysis of potential impacts to society, and options for mitigation. Recently, attention on ocean acidification and its consequences has gained momentum in the public sector, particularly since the release of the Kleypas and others (2006) report (for example, write-ups in Nature, August 2006, and The New Yorker, November 2006 issues). The report identifies declining oceanic pH and carbonate-ion concentrations as a consequence of increased atmospheric and surfaceocean carbon dioxide. The possible impact is providing questions that are amenable to both experimental and field study. Seibel and Fabry (2003, as summarized in Kleypas and others, 2006) postulated "if reduced calcification decreases a calcifying organism's fitness or survivorship, then such calcareous species may undergo shifts in their latitudinal distributions and vertical depth ranges as the $\mathrm{CO}_{2}$ /carbonate chemistry of seawater changes."

To date, very limited quantitative data exist with which to test this hypothesis, particularly in shelf environments. The continental shelves of Florida provide an ideal natural laboratory in which to test latitudinal (and depth) shifts in habitat ranges of calcifying organisms. Both the east and west Florida shelves extend from warm temperate to subtropical latitudes. Along this gradient, carbonate sedimentation changes from predominantly animal-produced shell hashes known as "heterozoan" carbonates that accumulate at rates of centimeters per 1,000 years, to subtropical reef environments where "photozoan" carbonate sediments are produced in association with photosynthesis, at rates that can exceed a meter per 1,000 years (hyper-calcification). Changes in either latitudinal or depth distributions of these benthic assemblages on the Florida shelves would provide convincing evidence of ecosystem-level effects of ocean acidification on calcifying organisms. The following report is a compilation of projects performed by students from the University of South Florida College of Marine Science, who participated in Dr. Pamela Hallock's cruise on the R/V Suncoaster during spring 2008.

\section{References Cited}

Kleypas, J.A, Feely, R.A., Fabry, V.J., Langdon, C., Sabine, C.L., and Robbins, L.L., 2006, Impacts of ocean acidification on coral reefs and other marine calcifiers: A guide for future research: Report of a workshop sponsored by National Science Foundation, National Oceanic and Atmospheric Administration and the U.S. Geological Survey, 88 p.

Seibel, B.A., and Fabry, V.J., 2003, Marine biotic response to elevated carbon dioxide: Advances in Applied Biodiversity Science, v. 4, p. 59-67.

${ }^{1}$ University of South Florida College of Marine Sciences, 140 7th Ave. South, St. Petersburg, FL 33701

${ }^{2}$ U.S. Geological Survey Coastal and Marine Science Center, 600 4th Street South, St. Petersburg, FL 33701 


\section{Contents}

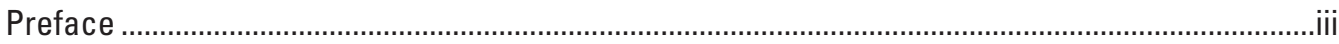

Section 1. Surface-Sediment Constituent Data ........................................................................... 1

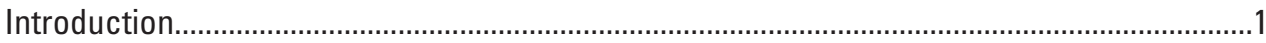

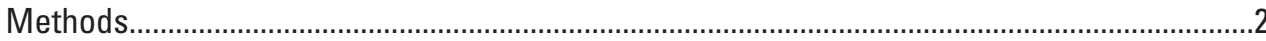

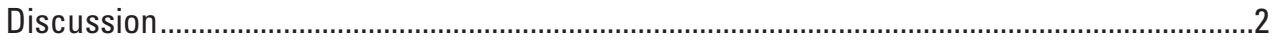

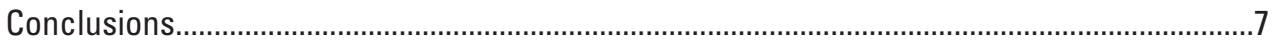

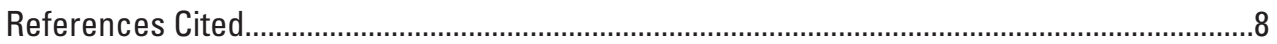

Section 2. Sediment Characteristics and Distribution along the West-Central Florida

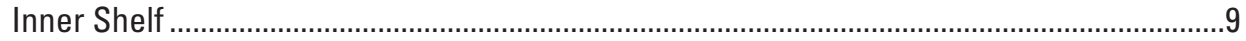

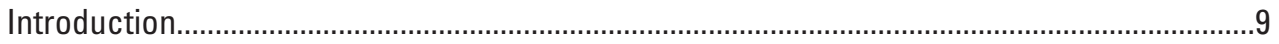

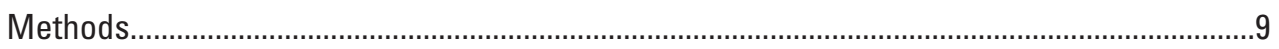

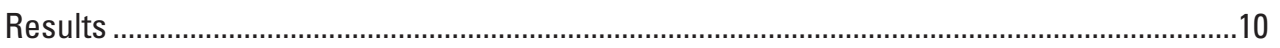

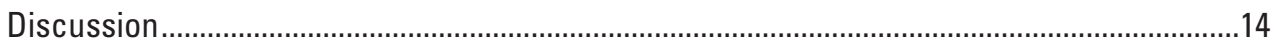

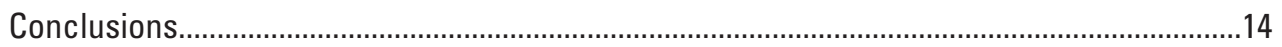

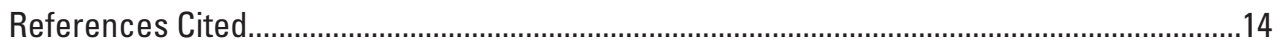

Section 3. Assessing Carbonate and Total Organic Content Trends in Sediments

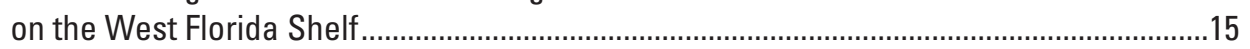

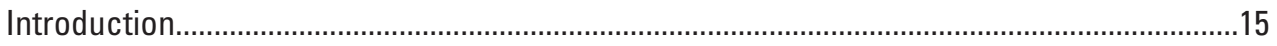

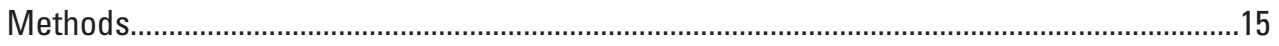

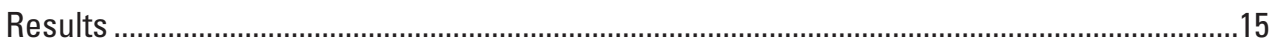

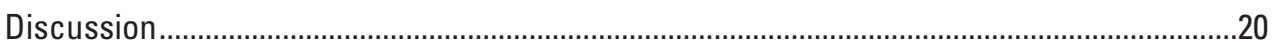

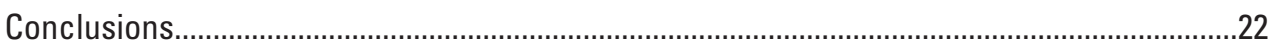

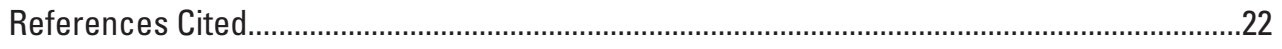

Section 4. West Florida Shelf: A Foraminiferal Perspective ..............................................................23

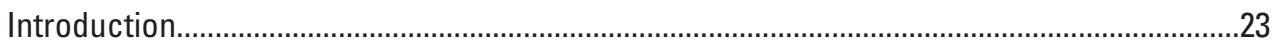

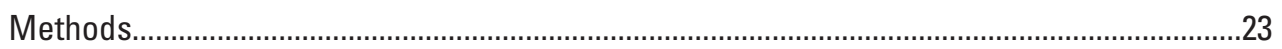

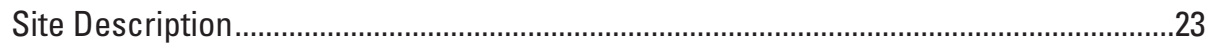

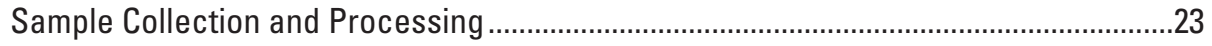

Mathematical Approach .............................................................................................25

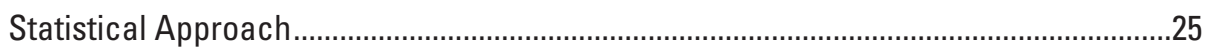

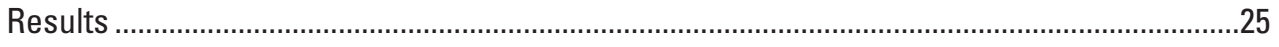

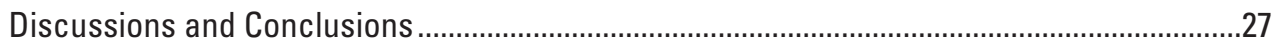

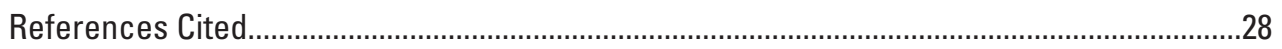

Section 5. Irradiance Data from the West Florida Shelf....................................................................22

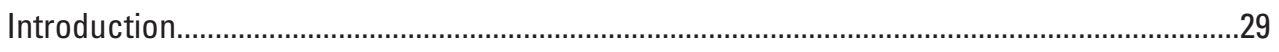

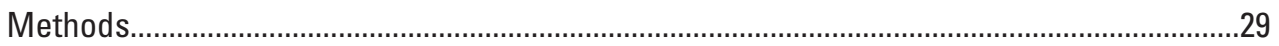

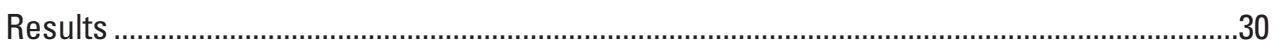

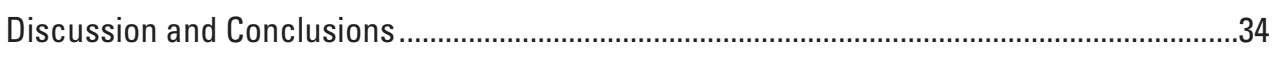

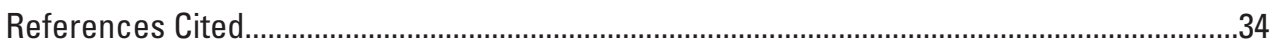

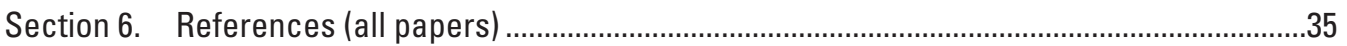

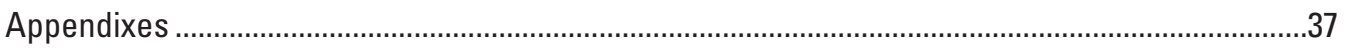




\section{Figures}

1.1. Map of Florida and the Gulf of Mexico showing the study area ...............................1

1.2. Map of west Florida shelf study area showing site locations ....................................

1.3. Graph showing relative abundance of constituents for the $30-\mathrm{m}$ depth-contour sites

1.4. Diagram showing carbonate grain types associated with foramol and chlorozoan assemblages .

1.5. Graph showing point count of percent constituents for $15-\mathrm{m}$ depth-contour sites

1.6. Microscope photographs (2-3 $\Phi$ and 3-4 $\Phi$ photographed under increased magnification) of whole phi intervals for sand and gravel fractions for site 03 along the $15-\mathrm{m}$ depth contour

1.7. Microscope photographs (2-3 $\Phi$ and 3-4 $\Phi$ photographed under increased magnification) of whole phi intervals for sand and gravel fractions for site 08 along the 15-m depth contour

1.8. Sea-surface temperature map of the west and southwest Florida shelves during an event of cold-water transport across the shelf and outcrop-at the coast near Charlotte Harbor and near the Dry Tortugas on May 17, 1998 ...........7

1.9. A cross section of shelf off Sarasota, $\mathrm{FL}$, shows temperature during an upwelling of colder deep water onto the west Florida shelf.

2.1. Map of study area showing station locations highlighted along the 15- and 30 - $\mathrm{m}$ isobaths

2.2. Maps of mean grain size contours across the study site and skewness (based on moment method) contours across the study site.

2.3. Graphs showing examples of typical sediment-fraction distribution; all samples except at site SC0408-3 are negatively skewed or strongly coarse-skewed.

2.4. Representation of gravel and carbonate percent for each sample site and illustration of the gravel, sand, and mud percentage for each sample site.

3.1. Bar graphs of the carbonate and total organic content (TOC) weight percentages at the $15-\mathrm{m}$ and $30-\mathrm{m}$ isobaths arranged from north to south showing the low amounts of carbonate and the rapid decrease-gradual increase trend from north to south

3.2-3.4 Maps Showing-

3.2. Tampa Bay area showing higher carbonate values ( $>80$ weight percent) in the southern part of the study area.

3.3. Nearshore area near Sarasota showing carbonate values of up to 93 weight percent.

3.4. West Florida shelf including samples with brackets denoting the rapid decrease to gradual increase trend from north to south

3.5. Graphs of nitrate and phosphate profiles from the west Florida shelf show a very similar rapid decrease to gradual increase trend in phosphate $\left(\mathrm{PO}_{4}\right)$ from north to south as observed in the TOC and carbonate percentages from the $15-\mathrm{m}$ isobath

3.6. Map of sample sites (yellow dots) and their locations relative to the southwest-striking topographic and bathymetric high between Tampa Bay and Charlotte Harbor Estuaries 
3.7. Microscope photographs showing dominant grain size at site SC0408-15 and SC0408-14, and the grains exhibit the dominant shift from carbonate to quartz (siliciclastic) material over the rapid-decrease trend. 21

3.8. Diagram of April mean current, magnitude, and direction shown by arrows ...........21

4.1. Map of the west Florida shelf study area ............................................................24

4.2. Bar graph showing foraminiferal morphogroup distribution, west Florida shelf......25

5.1. Photograph of a Bus Interface Controller (BIC) series multichannel cosine irradiance spectroradiometer.

5.2. Photograph of a scalar irradiance spectrometer attached to Spectrophotometric Elemental Analysis System (SEAS) instrument platform

5.3-5.8 Graphs Showing-

5.3. Measured versus modeled irradiance values, stations $1,6,7,12$, and $13 \ldots . .31$

5.4. Modeled data at sites $1,6,7,12$, and 13 at the 305 -nm wavelength ...............31

5.5. Modeled data at sites 1, 6, 7, 12, and 13 at the 330-nm wavelength...............32

5.6. Modeled data at sites $1,6,7,12$, and 13 at the 380 -nm wavelength...............32

5.7. Modeled data at sites $1,6,7,12$, and 13 at the Photosynthetically Available Radiation (PAR) band. 33

5.8. Photosynthetically Available Radiation (PAR) data modeled from the scalar irradiance spectroradiometer 33

\section{Tables}

2.1. Sediment characteristics, including sediment percentages and results of the moment method on sediment grain-size analysis, west Florida shelf .................10

2.2. Overall ranges of sediment characteristics, west Florida shelf...............................10

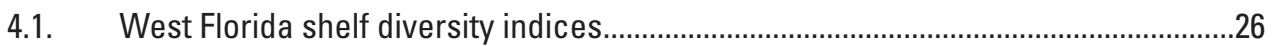

4.2. Pearson correlation factors between foraminiferal morphogroups, physical

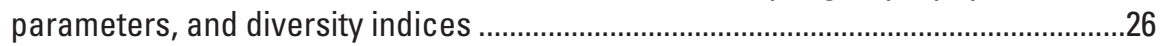

5.1. Cruise data used to derive extinction coefficient $(\mathrm{k})$ and intensity $\left(\mathrm{I}_{\mathrm{z}}\right) \ldots \ldots \ldots \ldots \ldots \ldots \ldots . . . . . . . . .30$

\section{Conversion Factors}

\begin{tabular}{lll}
\hline \multicolumn{1}{c}{ Multiply } & \multicolumn{1}{c}{ By } & \multicolumn{1}{c}{ To obtain } \\
\hline & \multicolumn{1}{c}{ Length } & \\
\hline centimeter $(\mathrm{cm})$ & 0.3937 & inch (in.) \\
millimeter $(\mathrm{mm})$ & 0.03937 & inch (in.) \\
meter $(\mathrm{m})$ & 3.281 & foot (ft) \\
kilometer $(\mathrm{km})$ & 0.6214 & mile (mi) \\
kilometer $(\mathrm{km})$ & 0.5400 & mile, nautical (nmi) \\
meter $(\mathrm{m})$ & 1.094 & yard (yd) \\
\hline
\end{tabular}

Temperature in degrees Celsius $\left({ }^{\circ} \mathrm{C}\right)$ may be converted to degrees Fahrenheit $\left({ }^{\circ} \mathrm{F}\right)$ as follows:

$$
{ }^{\circ} \mathrm{F}=\left(1.8 x^{\circ} \mathrm{C}\right)+32
$$




\section{Abbreviations and Acronyms}

\begin{tabular}{|c|c|}
\hline ASTM & American Society for Testing Materials \\
\hline BIC & Bus Interface Controller \\
\hline $\mathrm{cm} / \mathrm{s}$ & centimeters per second \\
\hline $\mathrm{Cl}$ & contour interval \\
\hline CTD & conductivity, temperature, depth \\
\hline DON & dissolved organic nitrate \\
\hline DOP & dissolved organic phosphate \\
\hline FAl & Fisher's Alpha Index \\
\hline IPCC & Intergovernmental Panel on Climate Change \\
\hline$<$ & less than \\
\hline$>$ & more than \\
\hline LOI & loss on ignition \\
\hline MICA & Multiparameter Inorganic Carbon Analyzer \\
\hline$\mu \mathrm{Em}^{-2} \mathrm{~s}^{-1}$ & microEinsteins per square meter per second \\
\hline$\mu$ Watts $/ \mathrm{cm}^{2} / \mathrm{nm}$ & microWatts per square centimeter per nanometer \\
\hline $\mathrm{Em}^{-2} \mathrm{~s}^{-1}$ & milliEinsteins per square meter per second \\
\hline$\mu \mathrm{m}$ & micrometers \\
\hline $\mathrm{nm}$ & nanometer \\
\hline$\Phi$ & phi size \\
\hline PAR & photosynthetically available radiation \\
\hline$\%$ & percent \\
\hline SEAS & Spectrophotometric Elemental Analysis System \\
\hline TOC & total organic content \\
\hline UVA & ultraviolet $A$ \\
\hline UVB & ultraviolet B \\
\hline
\end{tabular}





\title{
Section 1. Surface-Sediment Constituent Data
}

\author{
By Rebekka Larson'
}

\section{Introduction}

Declining oceanic $\mathrm{pH}$ and carbonate-ion concentrations are well-known consequences of increased atmospheric and surface-ocean partial pressure of carbon dioxide $\left(\mathrm{pCO}_{2}\right)$. The possible subject of shifts in seawater carbonate chemistry on biocalcification and survival rates of marine organisms provides questions amenable to both experimental and field study (Kleypas and Langdon, 2006). To date, limited quantitative data exist with which to formalize and test hypotheses regarding such impacts, particularly in continental-shelf settings. The continental shelves of Florida provide an ideal natural laboratory in which to test latitudinal (and temperature and depth) shifts in habitat ranges of calcifying organisms. Both the east and west Florida shelves extend from warm temperate to subtropical latitudes; additionally, the west Florida shelf has very little siliciclastic influx to mask the carbonate production.

This study utilizes the natural laboratory of the west and southwest Florida shelf (fig 1.1) to examine the transition from foramol (predominately foraminifera and molluscan) carbonate sediments, characteristic of the west-central Florida shelf, to chlorozoan (algal and coral) sediments characteristic of the southwest Florida shelf.

The west Florida shelf is a mixed siliciclastic carbonate ramp that to the south transitions to the carbonate-dominated southwest Florida shelf (Enos, 1977; Brooks and others, 2003). The west Florida shelf is a distally steepened carbonate ramp that is $\sim 250$ kilometers $(\mathrm{km})$ wide (Read, 1985). It is covered by a veneer of unconsolidated sediment consisting of mainly biogenic carbonate and quartz in the near shore, with subordinate amounts of phosphate. The sediment-distribution pattern is largely a function of proximity to source, with physical processes playing a minor role in distribution. The carbonate sand-and-gravel fraction is produced by organisms within the depositional basin of the west Florida shelf (Brooks and others, 2003). The southwest Florida shelf is a rimmed carbonate margin where organisms produce virtually all of the substrate; it also exhibits a greater sediment thickness as compared to the west Florida shelf (Enos, 1977).

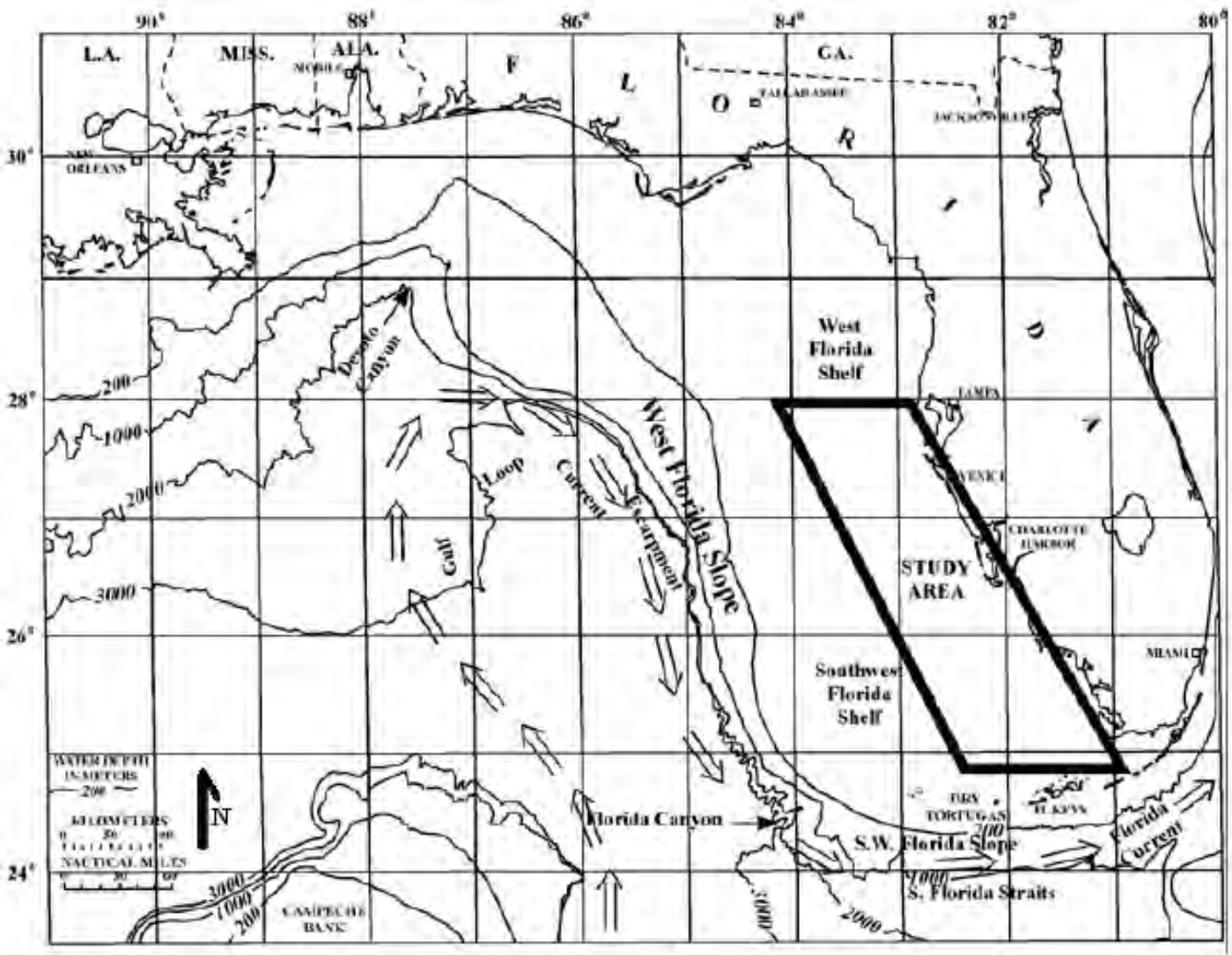

Figure 1.1 Florida and the Gulf of Mexico showing the study area (modified from Brooks and Holmes, in press; used with permission). 
Temperature, which is usually associated with latitude, plays a major role in locations of foramol versus chlorozoan assemblages, but other factors beyond latitude influence temperature on the west and southwest Florida shelves. The potential of cooler, deep-water upwelling and transport over the bottom waters of the shelf may have a significant role in the species assemblage at the sediment/water interface and ultimately on location of foramol versus chlorozoan production. Deep water transported onto and over the shelf may also have environmental ramifications beyond temperature by bringing in water of different chemistry.

\section{Methods}

Sampling was performed April 1-4, 2008, aboard the R/V Suncoaster along the west and southwest Florida shelves from offshore Tampa Bay to the Florida Keys. Surface-sediment samples were collected using a Shipek grab sampler along the 15-meter $(\mathrm{m})$ and 30-m depth contours. Samples were collected at $\sim 3$-hour intervals, beginning south of Tampa Bay. Sites 01-09 followed the 15-m depth contour from north to south. Sites 10 - 18 followed the 30-m depth contour from south to north (app. 1.1, fig.1.2).

Surface-sediment samples were split into an archive bulk sample for laboratory analyses including grain size (see Beck, this report), carbonate content, and total organic content (see Schwing, this report), as well as sediment-constituent analyses described in this report. The onboard sample was sieved through a $1-\Phi(0.5$-millimeter $(\mathrm{mm}))$ screen and analyzed using point counts of $\sim 300$ grains to determine sediment constituents of the coarser than 1- $\Phi$ size fraction (Carver, 1971). The bulk archive sample was transported to the laboratory where it was washed and dried for sieving at whole phi intervals. Each whole phi interval of the sand-andgravel fraction was photographed under the microscope for identification of sediment constituents and constituent fractionation between $\Phi$ sizes. Shipboard and laboratory analyses were compared and analyzed for sedimentconstituent trends and(or) correlations with latitude, depth, and grain size, as well as foramol or chlorozoan associations.

\section{Discussion}

Shipboard point counting of the coarser than 1- $\Phi$ fraction identified quartz, phosphate, mollusk, foraminifers, bryozoan, calcareous and coralline algae, and unidentifiable grains (apps. $1.2,1.3$, and 1.4). Mollusks were in relatively high abundance in all samples, with variations in phosphate as well as minor amounts of calcareous and coralline algae, quartz, foraminifers, bryozoans, and unidentifiable grains. Sites along the 30-m depth contour reflected dominance by mollusks, a lower abundance of phosphate and foraminifers, and even lesser amounts of bryozoans, quartz, and calcareous and coralline algae (fig. 1.3). The phosphate may be an indication of proximity to outcropping phosphate-rich limestones that are bioeroded and thereby have liberated the phosphate grains (Brooks and others, 2003). The highest abundance of foraminifers was located at site 11 , which is near the southern edge of the study area (fig. 1.2). There are no apparent correlations with latitude along the 30-m depth contour, and all samples seem to reflect a foramol assemblage (fig. 1.4) (Lees and Buller, 1972).

Point counting of samples along the 15-m depth contour similarily reflects the dominance of mollusks with variations in phosphate but shows substantial variations in calcareous and coralline algae, bryozoans, and foraminifers, as well as minor abundance of quartz and unidentifiable grains (fig. 1.5). Once again, the phosphate is most likely a function of proximity to outcropping phosphate-rich limestone. The large percentage at site 03 is offshore from the Venice headland, which is a location where phosphate-rich sands crop out along the inner shoreface (Hine and others, 2003). Site 18 off Tampa Bay is the only site with significant amounts of foraminifera. An increase in abundance of calcareous and coralline algae at sites 07, 08, and 09 along the southern section of the $15-\mathrm{m}$ depth contour indicated a transition to a chlorozoan assemblage in the southern sites of this transect (fig. 1.4) (Lees and Buller, 1972). Conversely, site 07 contains a significant amount of bryozoans, which are indicative of a foramol assemblage. The bryozoans are found in large amounts at this site only and decrease to nominal amounts farther south. Therefore, along the 15-m depth contour, the transition occurs from a foramol assemblage dominated by only mollusks to a chlorozoan assemblage with increased calcareous and coralline algae between sites 06 and 07.

Point counting of the coarser than 1- $\Phi$ size fraction indicates that quartz grains are in relatively low amounts or are absent in all samples. Microscope photography revealed that essentially all quartz grains were found in the finer than $1-\Phi$ size fraction, with the majority finer than $2 \Phi$ (fig. 1.6). The quartz is generally well sorted and rounded, and there is a decrease in quartz from the $15-\mathrm{m}$ depth contour to the $30-\mathrm{m}$ depth contour. Quartz grains are commonly found off Tampa Bay with a general increase to the south toward Charlotte Harbor. The majority of quartz is located off Charlotte Harbor, where it makes up most of all grains in the finer than 2- $\Phi$ size fraction. South of site 04, quartz decreases dramatically, with little to no quartz found at the $15-\mathrm{m}$ or $30-\mathrm{m}$ depth contours. This represents the southern extent of quartz sand deposition. These data agree well with previous works by Brooks and others (2003), which stated that the quartz sand is found close to the source (coastline and barrier-island system), and Enos (1977), who defined the quartz sand as terminating just south of the Cape Romano Shoals (N' 25.84205, W' -81.66314).

Identification of carbonate constituents using microscope photography was constrained to the larger size fractions (those coarser than $0 \Phi$ ), because the larger grains are easier to see and identify and because they are less weathered and 


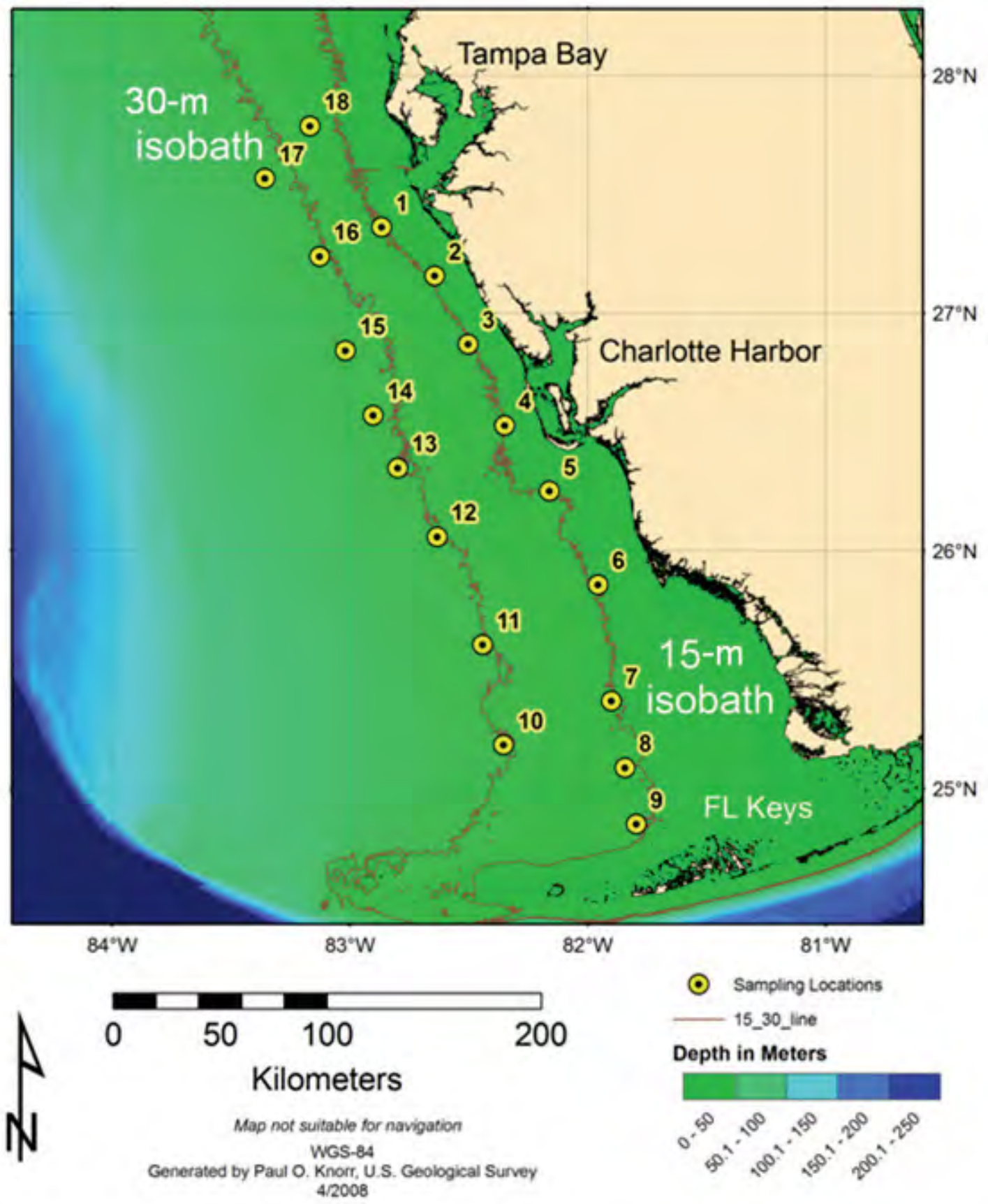

Figure 1.2 West Florida shelf study area showing site locations. 
Sediment Constituents (Deep, 30 m)

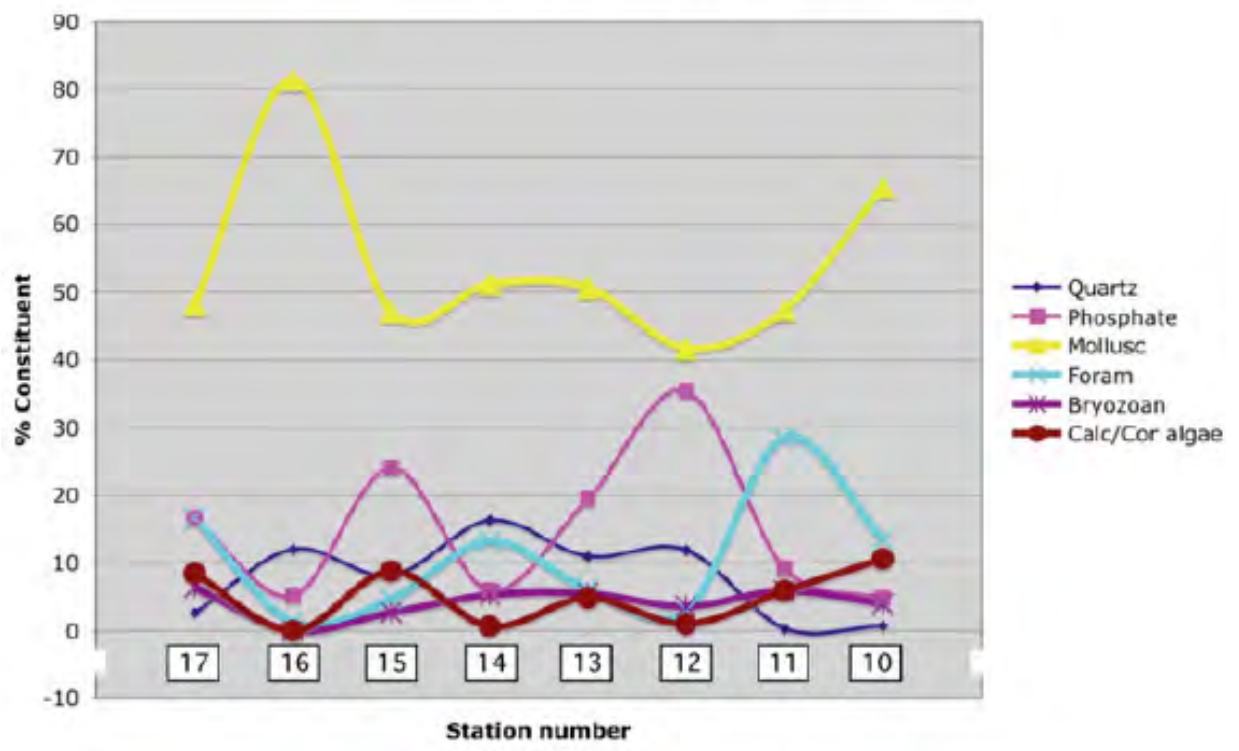

Figure 1.3 Relative abundance of constituents for the $30-\mathrm{m}$ depth-contour sites. Note the nominal calcareous and coralline algae at all sites, determined by point counts of $\sim 300$ samples.
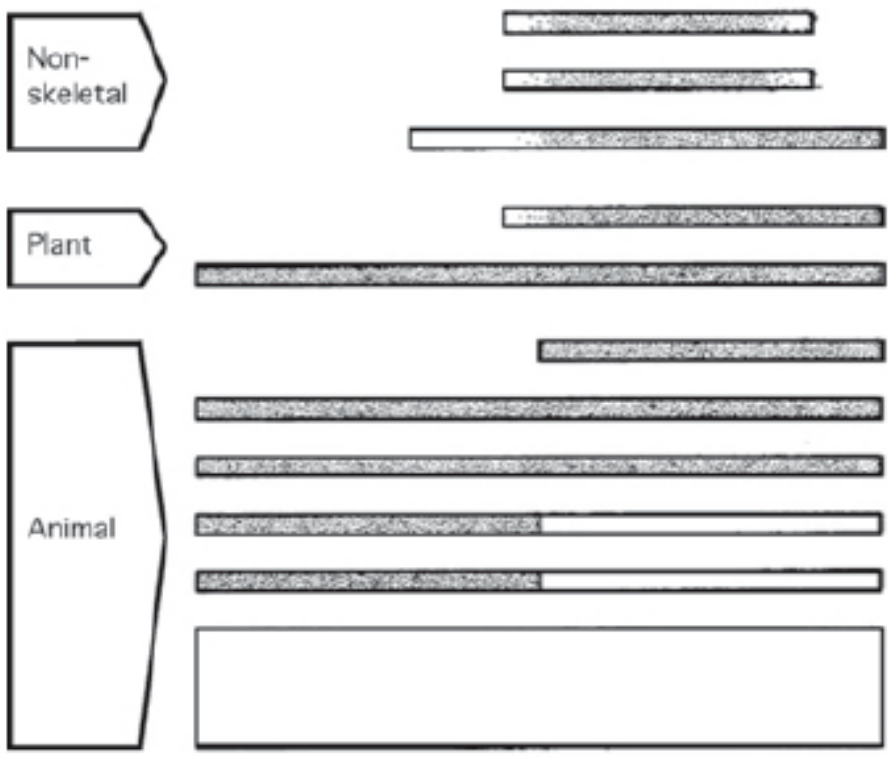

E.
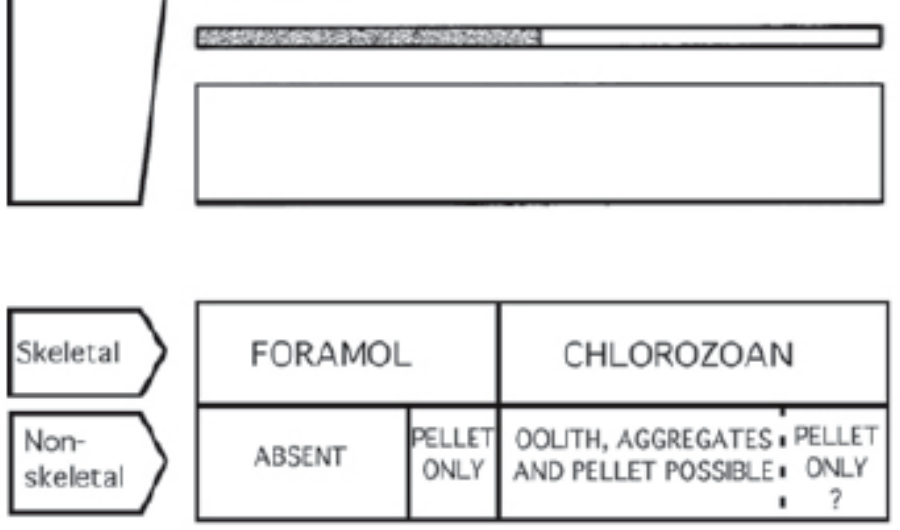

OOLITH

AGGREGATES

PELLET

\section{GREEN CALCAREOUS \\ RED ALGAE}

CORAL (hermatypic)

MOLLUSC

FORAM (benthic)

\section{BRYOZOA}

\section{BARNACLE}

OTHER (echinoderm, ostracod, sponge, spicule, worm tube, ahermatypic corali,

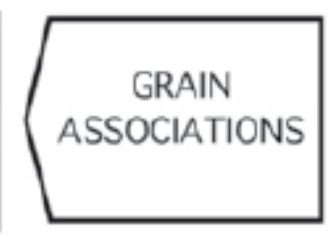

Figure 1.4 Carbonate grain types associated with foramol and chlorozoan assemblages. Shading in bars indicates that the grain type may be important or a dominant constituent (Lees and Buller, 1972). 
Figure 1.5 Point count of percent constituents for 15 -m depth-contour sites. Note the peak in calcareous and coralline algae at sites 07,08 , and 09 .

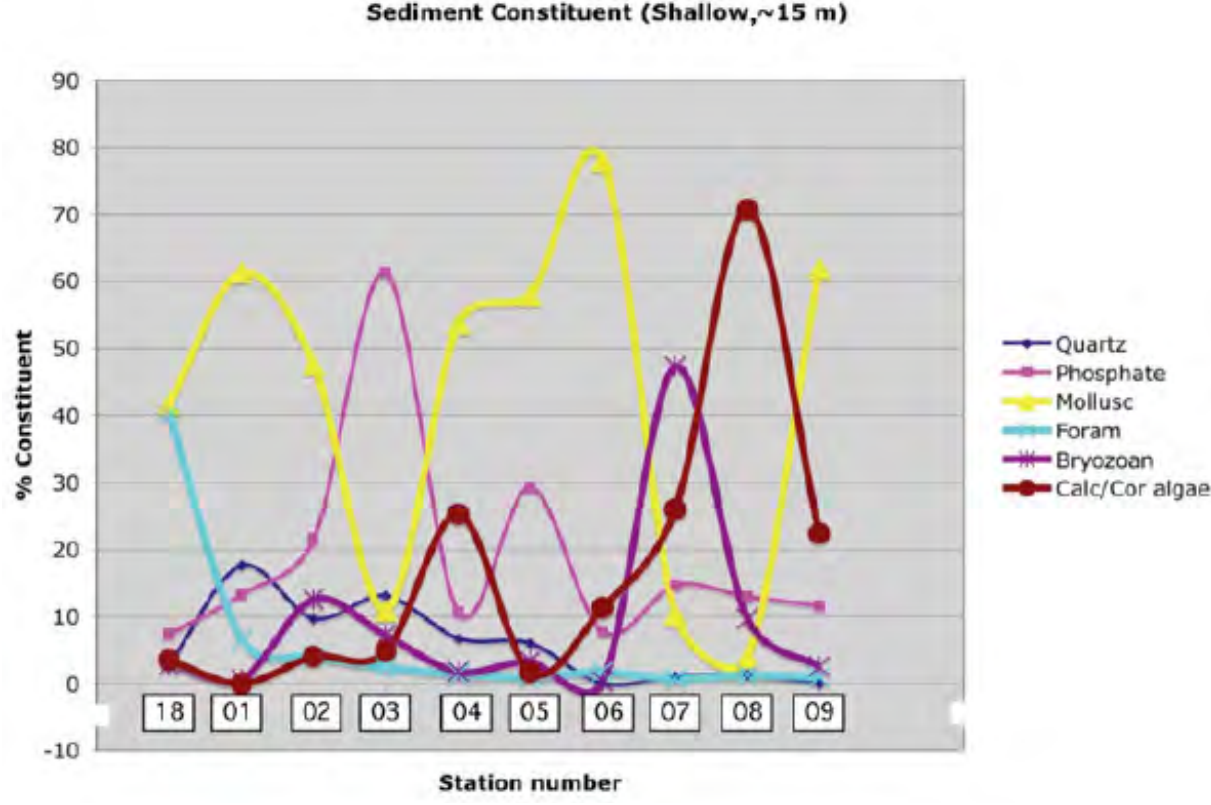

WFS-SC-04-08 Station 03, Shallow ( $15 \mathrm{~m})$

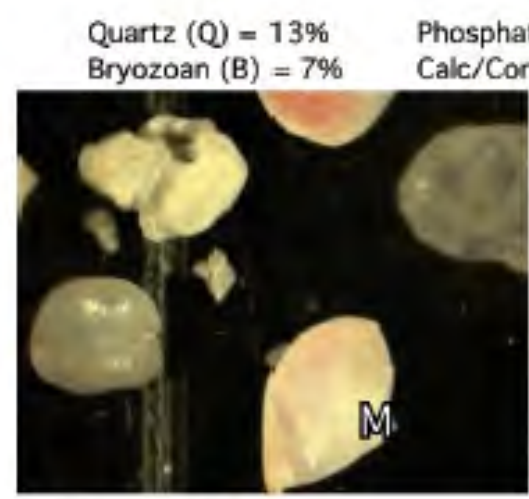

$>-1$ phi $=0.65 \%$

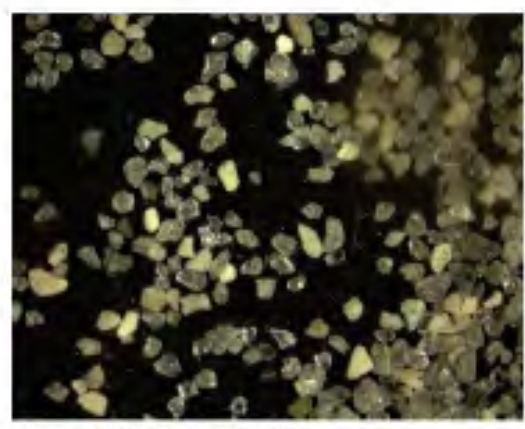

1 to $2 \mathrm{phi}=45.80 \%$ te $(P)=61 \% \quad$ Mollusc $(M)=11$

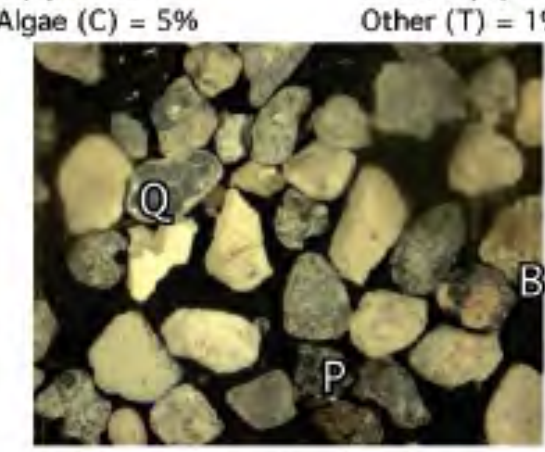

-1 to 0 phi $=5.33 \%$

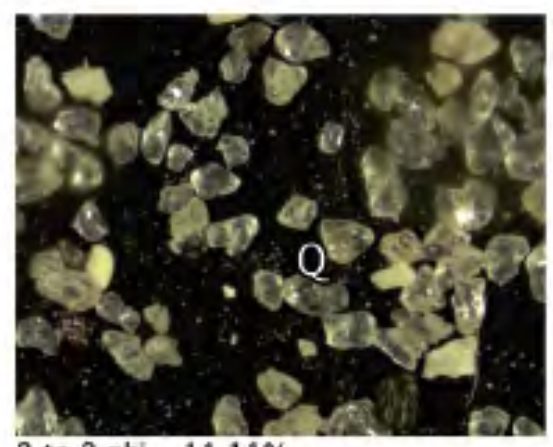

2 to 3 phi $-11.11 \%$

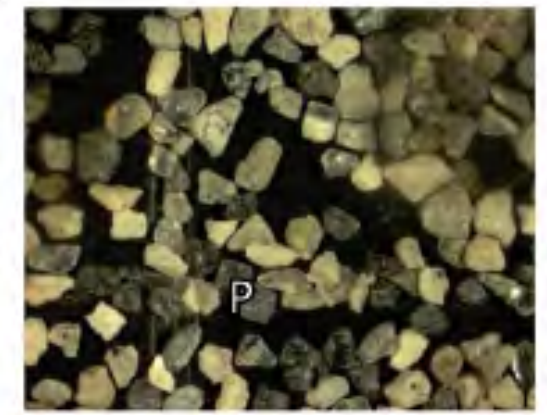

0 to $1 \mathrm{phi}=35.83 \%$

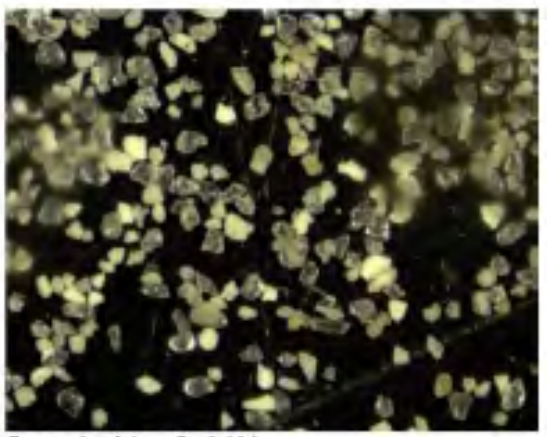

3 to $4 \mathrm{phi}=0.44 \%$

Figure 1.6 Microscope photographs (2-3 $\Phi$ and 3-4 $\Phi$ photographed under increased magnification) of whole phi intervals for sand-and-gravel fractions for site 03 along the 15-m depth contour. Note the worn and rounded nature of the grains and that most quartz grains are $<1 \Phi$. Also note presence of black phosphatic grains. The weight percent of each size fraction from Beck (this volume). Note: this figure also in appendix, where complete sediment data resides. 


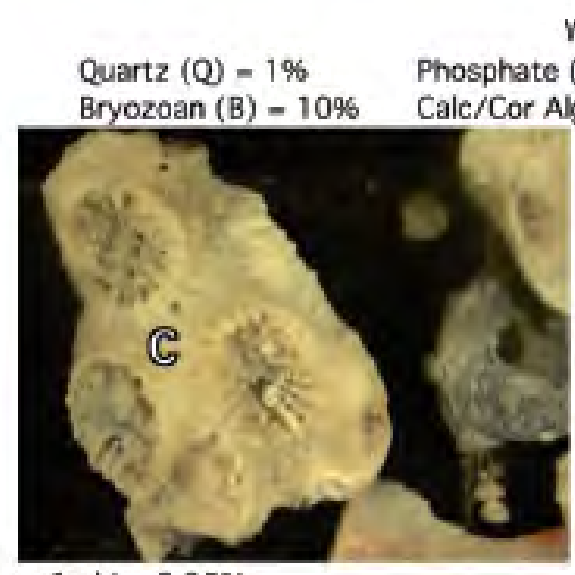

$>-1$ phi $=8.95 \%$

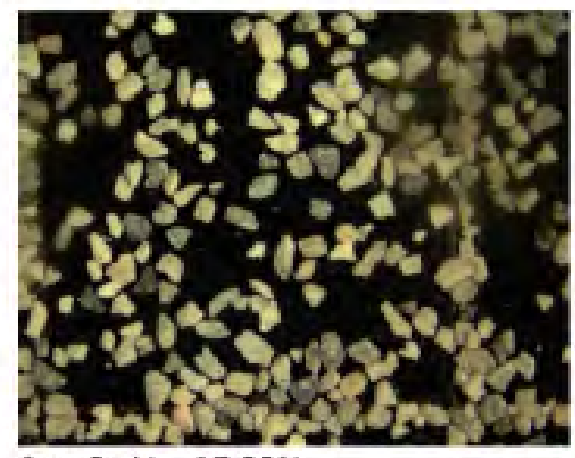

1 to 2 phi $=17,83 \%$
WFS-SC-04-08 Station 08, Shallow $(-15 \mathrm{~m})$

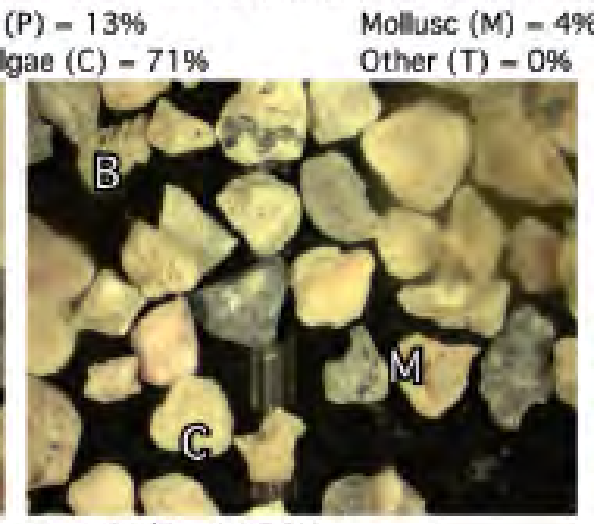

-1 to 0 phi $=14.26 \%$

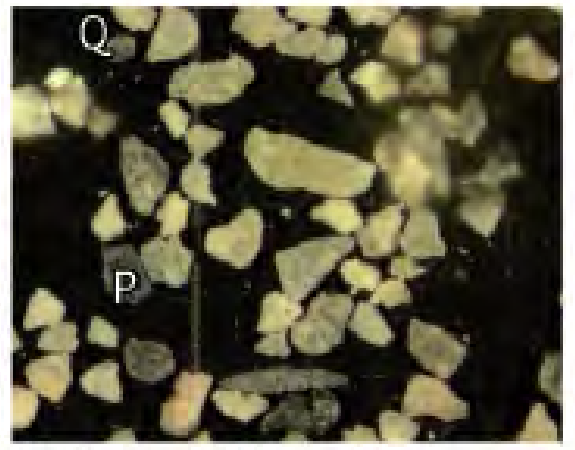

2 to $3 \mathrm{phi}=1.42 \%$
Foram $(F)=1 \%$

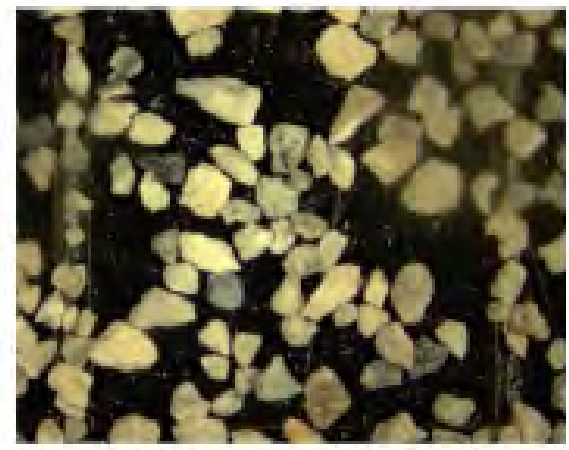

0 to $1 \mathrm{phi}=55.68 \%$

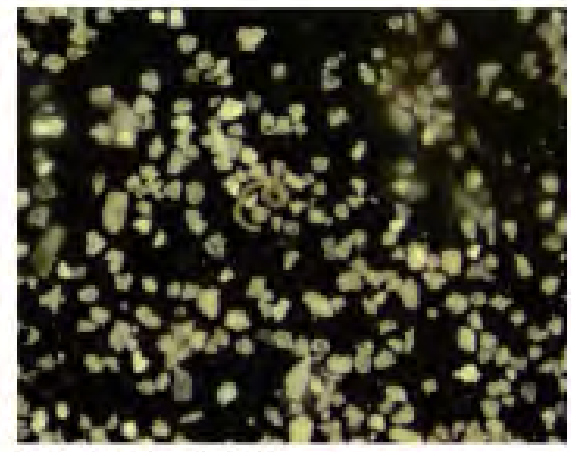

3 to 4 phi $=0.43 \%$

Figure 1.7 Microscope photographs (2-3 $\Phi$ and 3-4 $\Phi$ photographed under increased magnification) of whole phi intervals for sand-and-gravel fractions for site 08 along the $15-\mathrm{m}$ depth contour. Note worn and rounded nature of the grains, lack of quartz grains in any size fraction, as well as presence of chlorozoans in the $<-1 \Phi$ size fraction. The weight percent of each size fraction from Beck (this volume). Note: this figure also in appendix, where complete sediment data resides.

fragmented. Microscope photographs reflect similar trends to the point-count results, with mollusks dominating the majority of sites at the $15-\mathrm{m}$ and $30-\mathrm{m}$ depths. Once again, sites 07, 08, and 09 reflect the presence of calcareous and coralline algae, supporting the transition from a foramol assemblage north of site 07 to a chlorozoan assemblage at site 07 and to the south (fig. 1.7). Although site 10 is at a similar latitude to site 07 , the 30 -m-depth site 10 reflects a foramol assemblage. This may be a product of water temperature variability in this area. Sea surface temperature in the nearshore area north of the Florida Keys reflects warmer water (sites 07, 08, 09), with cooler waters to the north and offshore (site 10) (Weisberg and others, 2004). According to Weisberg and others (2004), there is evidence of Loop Current interactions (fig. 1.1) at the shelf slope break bringing deep, relatively cold water close to the surface north and west of the Dry Tortugas (fig. 1.8).

It is also possible that under certain conditions the oceanographic currents and upwelling of cooler water can affect sites along the 30-m depth contour and potentially the 15 -m depth contour north of site 07 across the whole west Florida shelf, through onshore bottom Ekman layer transport of deep cooler water. This process is reflected on the shelf by sharp thermoclines with up to $8{ }^{\circ} \mathrm{C}$ cooler water than surface temperatures, as well as cooler water upwelling at the surface near the coast (fig. 1.9) (Weisberg and others, 2004). These conditions are not likely persistent but may be sufficient in strength, frequency, and (or) duration to inhibit growth of animals associated with the chlorozoan assemblage north of site 07 and offshore sites 07,08 , and 09 . 


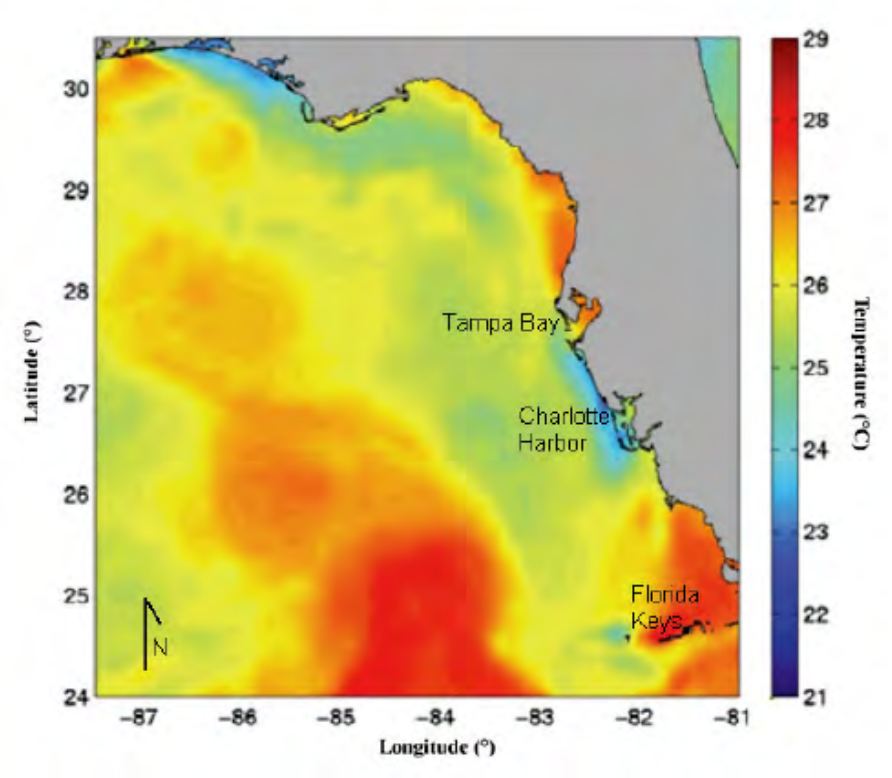

Figure 1.8 Sea-surface temperature map of the west and southwest Florida shelves during an event of cold-water transport across the shelf and outcrop-at the coast near Charlotte Harbor and near the Dry Tortugas on May 17, 1998. Note the warm (red) waters north of the Florida Keys (modified from Weisberg and others, 2004).

\section{Conclusions}

This study provides insight into the transition from foramol to chlorozoan assemblages on the west and southwest Florida shelves, including potential controls of carbonate production. These insights include the following:

1. Quartz sand-grain abundance was underestimated in shipboard point counting due to its presence almost exclusively contained in the finer than 1- $\Phi$ size fraction, with the majority finer than $2 \Phi$. Quartz sand-grain abundance decreases from the $15-\mathrm{m}$ to the 30-m depth contour, with quartz present off Tampa Bay and dominating the finer than 1- $\Phi$ sand fractions off Charlotte Harbor at both depth contours. Quartz sand grains dramatically decrease and become scarce south of Charlotte Harbor (south of site 04).

2. Carbonate-constituent data reflect dominance by mollusks at all sites with no major changes from the 15 -m to 30-m depths with the exception of the southern (sites $07,08,09) 15-m$ depth sites, which show an increase in calcareous and coralline algae.

3. The 15-m-depth transect reflects a shift from a foramol assemblage to a chlorozoan assemblage between sites 06 and 07 , with chlorozoan assemblages in sites 07, 08, and 09. This change may reflect more favorable environmental

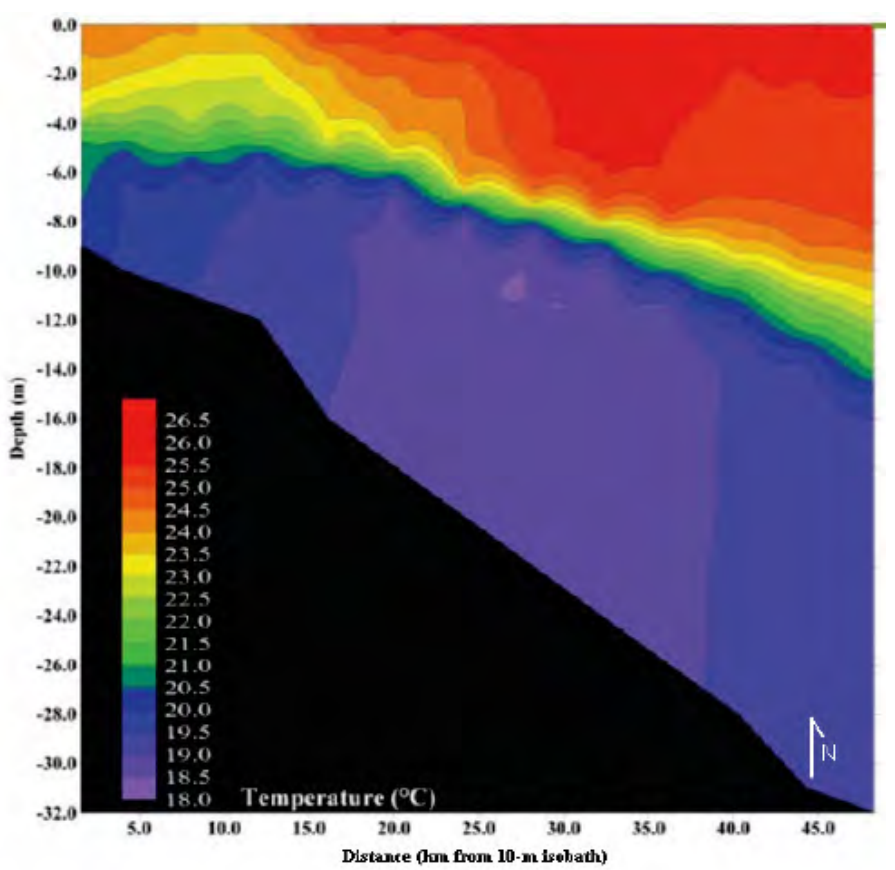

Figure 1.9 A cross section of shelf off Sarasota, FL, shows temperature during an upwelling of colder deep water onto the west Florida shelf. Note the sharp thermocline at the purple/ green contact (modified from Weisberg and others, 2004).

conditions for production by chlorozoan species, likely increased temperature with decreased latitude.

4. A foramol assemblage is associated with all $30-\mathrm{m}$ depth sites even at the southern section of the transect, indicating that these sites are under less favorable conditions for chlorozoan production compared to their inshore site at similar latitude. This factor may be an indicator of deep colder water influence due to oceanographic conditions associated with the Loop Current.

Suggested future work includes increased sampling resolution over the transition from foramol to chlorozoan assemblages, and over latitudinal changes as well as inshore to offshore changes. Understanding present conditions that limit and increase stress on chlorozoan production potentially will aid our understanding of the effects of additional limits and stresses to production associated with changes in water chemistry, particularly decreasing $\mathrm{pH}$. Investigations into the magnitude and frequency of cooler deep-water influence on the shelf over the areas of transition as well as surface-water temperature and its role in foramol versus chlorozoan production may aid in our understanding of the nature of transition from foramol to chlorozoan assemblages, and how the transition has changed in the past and may change in the future in response to alterations in climate, oceanographic currents, and in water chemistry. 


\section{References Cited}

Brooks, G.R., Doyle, L.J., Davis, R.A., DeWitt, N.T., and Suthard, B.C., 2003, Patterns and controls of surface sediment distribution: West-central Florida inner shelf: Marine Geology, v. 200, p. 307-324.

Brooks, G.R., and Holmes, C.W., in press, West Florida Continental Shelf, in Buster, N.A., and Holmes, C.W., eds., Gulf of Mexico, origin, waters, and biota: Volume 3, Geology: College Station, TX, Texas A\&M Press.

Carver, R.E., ed., 1971, Procedures in sedimentary petrology: New York, NY, Wiley, 653 p.

Enos, P., 1977, Holocene sediment accumulations of the South Florida shelf margin, in Enos, P., and Perkins, R.D., eds., Quaternary sedimentation in South Florida: Geological Society of America memoir 147: Boulder, CO, p. 1-130.

Hine, A.C., Brooks, G.R., Davis, R.A., Duncan, D.S., Locker, S.D., Twichell, D.C., and Gelfenbaum, G., 2003, The westcentral Florida inner shelf and coastal system: A geologic conceptual overview and introduction to the special issue: Marine Geology, v. 200, no. 1-4, p. 1-17.
Kleypas, J.A., and Langdon, Chris, 2006, Coral reefs and changing seawater carbonate chemistry, in Phinney, J.T., Hoegh-Guldberg, O., Kleypas, J., Skirving, W., and Strong, A., eds., Coral reefs and climate change: Science and management: Coastal and Estuarine Studies: Washington, D.C., American Geophysical Union, Monograph Series, v. 61, p. $73-110$.

Lees, A., and Buller, A.T., 1972, Modern temperate-water and warm-water shelf carbonate sediments contrasted: Marine Geology, v. 13, p. 67-73.

Read, J.F., 1985, Carbonate platform facies models: American Association of Petroleum Geologists Bulletin, v. 66, no. 1, p. $860-878$.

Weisberg, R.H., He, Ruoying, Kirkpatrick, Gary, MullerKarger, Frank, and Walsh, J.J., 2004, A west Florida case study: Coastal ocean circulation influences on remotely sensed optical properties: Oceanography, v. 17, no. 2, p. 69-75. 


\title{
Section 2. Sediment Characteristics and Distribution along the West-Central Florida Inner Shelf
}

\author{
By Tanya Beck ${ }^{1}$
}

\section{Introduction}

The continental shelf is a unique depositional system where controlling environmental factors are numerous and geologic history is complex and difficult to model. Continental-shelf systems are separated into terrigenous clastic shelves, carbonate platforms, and mixed carbonate/ and siliciclastic depositional systems. The combination of sediment types, both carbonate and siliciclastic, in a mixed depositional system, makes for even greater complexity when considering the environmental controlling factors of sedimentation on the shelf.

Wright (1995) defined the inner continental shelf as the region immediately seaward of the surf zone where the substrate is influenced by waves. This part of the shelf is morphologically important and serves as the conduit for particle transport across the shelf (Brooks and others, 2003). The proximity and direct link to the coast and its sediments provide an ideal environment to study both coastal and carbonate influx from heterozoan and photozoan associations.

The continental shelves of Florida extend from warm temperate to subtropical latitudes. They provide an ideal natural laboratory in which to test latitudinal changes in habitat of calcifying organisms, particularly the west shelf of Florida because of its broad expanse. From north to south, sedimentation changes from predominantly animal-produced heterozoan (shell hash) carbonates to subtropical reef environments, where photozoan (photosynthetic) carbonate sediments are produced. Sediment distribution in either a latitudinal or cross-shelf direction on the west Florida shelf may provide a link to environmental controls on calcifying organisms.

The objectives of this study are to determine the sediment characteristics and distribution across the inner part of the west Florida shelf. Sediment analysis of samples taken along photic isobaths $(15 \mathrm{~m}$ and $30 \mathrm{~m})$ aid in understanding the distribution of sediment across the depositional transition.
The results are compared with current shelf models for the west Florida shelf.

\section{Methods}

Surface-sediment samples were collected at each station location with a Shipek grab sampler. Stations were located along the 15-m and 30-m isobaths (fig. 2.1). Sample locations

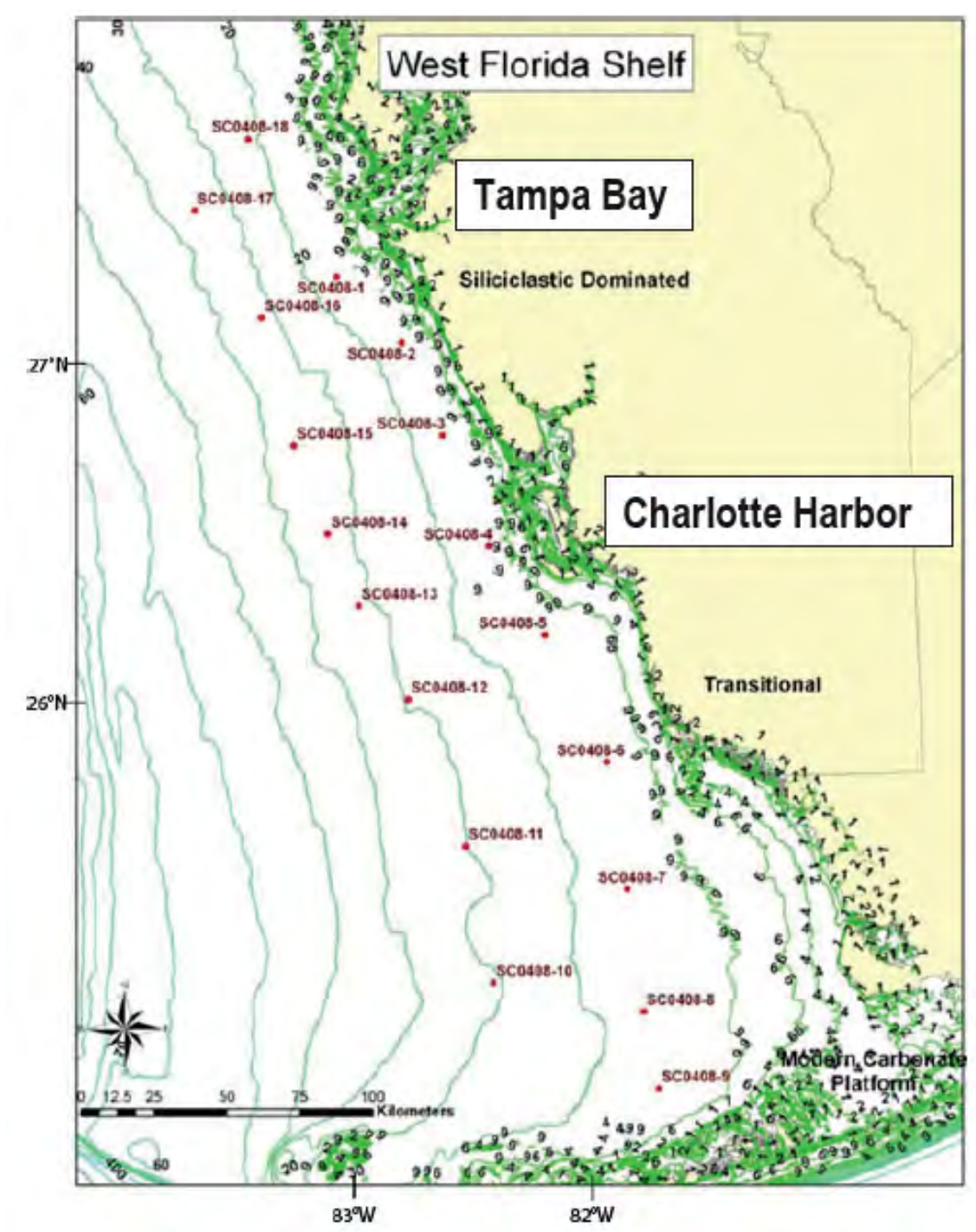

Figure 2.1 Study area showing station locations highlighted along the 15- and 30-m isobaths. Isobaths shown in green. Black numbers 9 and $<9$ represent depths $<10 \mathrm{~m}$. 
were determined on the basis of temporal and spatial conditions. An approximately 3-hour interval separated each site (approximately 30-60 km apart), and stopping location was based on optimal depths at or near the isobaths of interest. The only exception to this pattern was sample site SC0408-18, located offshore from Sand Key (depth $21 \mathrm{~m}$ ).

Sediment analysis was conducted by both wet- and dry-sieve methods (Folk, 1965). The fine fraction $(<62$ micrometers, $\mu \mathrm{m})$ was filtered through a U.S. Standard Sieve \#230 (4 Ф), dried, and weighed. The sand-and-gravel fraction was dried and sieved through $0.5-\Phi$ sieve intervals according to the American Society for Testing Materials (ASTM) Standard Materials Designation D422-63 for particle-size analysis of soils (American Society for Testing Materials, 1989). Grain-size analysis was entered into a standard spreadsheet and calculated on the basis of weight percent on phi intervals. Mean grain-size calculations were based on the moment method, where the cumulative phi were calculated from mid-phi percentages on the basis of the sedimentweighted percent. D50 median grain size is calculated on the basis of the phi sizes greater than and less than the cumulative weight of 50 percent. Standard deviation is calculated in phi scale only or phi standard deviation after Folk (1974).
Splits of each sample were analyzed for carbon with loss on ignition and for $\mathrm{CaCO}_{3}$ with HLC.

\section{Results}

Results of grain size analyses are summarized in table 2.1 and are included in appendix 2.1. Mean grain sizes ranged from $0.4 \Phi$ to $3 \Phi$ or from $0.75 \mathrm{~mm}$ to $0.11 \mathrm{~mm}$. Mean grain sizes ranged from very fine to coarse sand with standard deviations of as much as $1.8 \Phi$. Mean grain sizes along each transect, for example, along the $15-\mathrm{m}$ isobath, from sample site to adjacent site, can range from as much as $1.7 \Phi$.

Sediments that are negatively skewed have a "tail" of excess coarse particles (Boggs, 1987). All samples but one (SC0408-3) were negatively skewed, as evident in the tail of coarse sediment in each sample (fig. 2.2A, B; app. 2.1). Much of the sediment was strongly coarse-skewed, based on the 1974 interpretation of skewness of Folk. This is directly related to the percentage of coarse sand and gravel in the sample (fig. 2.3).

Table 2.1 Sediment characteristics, including sediment percentages and results of the moment method on sediment grain-size analysis, west Florida shelf.

$[\%$, percent; $\Phi$, phi size; D50, median grain size calculated on basis of phi sizes greater than and less than the cumulative weight of 50 percent]

\begin{tabular}{|c|c|c|c|c|c|c|c|}
\hline ID & Gravel (\%) & Sand $(\%)$ & Mud (\%) & Mean ( $\Phi)$ & D50 & $\begin{array}{l}\text { Standard } \\
\text { Deviation }\end{array}$ & Skewness \\
\hline SC0408-1 & 0.648 & 98.746 & 0.606 & 1.589 & 2.231 & 0.851 & -0.629 \\
\hline SC0408-2 & 1.429 & 86.663 & 11.908 & 2.862 & 3.556 & 1.155 & -1.991 \\
\hline SC0408-3 & 0.645 & 98.509 & 0.846 & 1.163 & 1.664 & 0.811 & 0.111 \\
\hline SC0408-4 & 5.626 & 93.572 & 0.802 & 0.706 & 1.208 & 1.081 & -0.052 \\
\hline SC0408-5 & 3.167 & 95.398 & 1.435 & 0.706 & 1.199 & 0.887 & -0.004 \\
\hline SC0408-6 & 1.301 & 97.887 & 0.812 & 1.401 & 1.941 & 0.914 & -0.610 \\
\hline SC0408-7 & 6.992 & 91.398 & 1.610 & 1.029 & 1.589 & 1.365 & -0.644 \\
\hline SC0408-8 & 8.946 & 89.611 & 1.444 & 0.432 & 1.064 & 1.097 & -0.785 \\
\hline SC0408-9 & 4.333 & 66.167 & 29.501 & 1.975 & 2.213 & 1.799 & -0.277 \\
\hline SC0408-10 & 0.840 & 52.464 & 46.696 & 2.987 & 4.002 & 1.411 & -1.031 \\
\hline SC0408-11 & 0.103 & 90.515 & 9.381 & 2.525 & 2.959 & 0.856 & -0.249 \\
\hline SC0408-12 & 4.694 & 93.157 & 2.149 & 1.419 & 2.131 & 1.201 & -1.558 \\
\hline SC0408-13 & 1.971 & 96.038 & 1.990 & 1.801 & 2.468 & 0.982 & -1.204 \\
\hline SC0408-14 & 2.737 & 95.535 & 1.728 & 1.555 & 2.290 & 1.052 & -0.927 \\
\hline SC0408-15 & 0.056 & 89.591 & 10.353 & 2.796 & 3.380 & 0.893 & -0.842 \\
\hline SC0408-16 & 0.360 & 98.018 & 1.621 & 1.765 & 2.298 & 0.696 & -0.265 \\
\hline SC0408-17 & 0.085 & 78.957 & 20.958 & 2.731 & 3.350 & 1.141 & -0.602 \\
\hline SC0408-18 & 0.188 & 98.488 & 1.324 & 2.450 & 2.967 & 0.655 & -1.039 \\
\hline
\end{tabular}

Table 2.2 Overall ranges of sediment characteristics, west Florida shelf.

[Note that the range of the variance range overall is much larger than the maximum site to adjacent site range. $\%$, percent; $\Phi$, phi size; D50, median grain size calculated on basis of phi sizes greater than and less than the cumulative weight of 50 percent]

\begin{tabular}{|c|r|r|r|r|r|r|r|}
\hline Ranges & Gravel (\%) & Sand (\%) & Mud (\%) & Mean (Ф) & \multicolumn{1}{c|}{ D50 } & $\begin{array}{r}\text { Standard } \\
\text { Deviation }\end{array}$ & Skewness \\
\hline Minimum & 0.056 & 52.464 & 0.606 & 0.432 & 1.064 & 0.655 & -1.991 \\
\hline Maximum & 8.946 & 98.746 & 46.696 & 2.987 & 4.002 & 1.799 & 0.111 \\
\hline
\end{tabular}



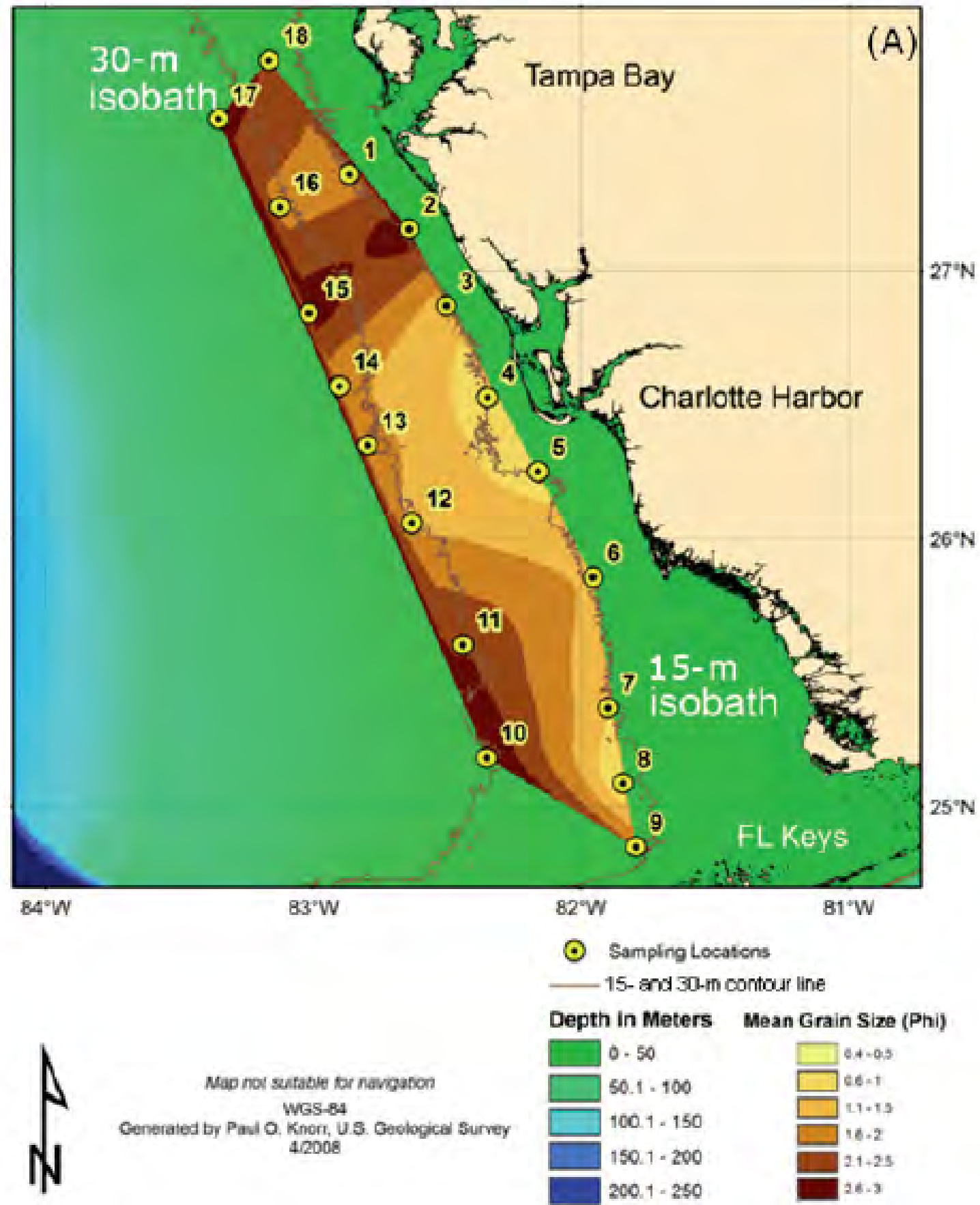

Depth in Meters

Mean Grain Size (Phi)

\begin{tabular}{l}
\hline 0.50 \\
$\square 0.1-100$ \\
$100.1-150$ \\
$150.1-200$ \\
$200.1-250$
\end{tabular}

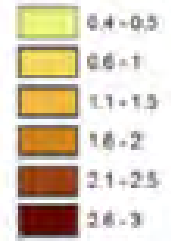

Figure 2.2 Maps of $A$, mean grain-size contours across the study site and $B$, skewness (based on moment method) contours across the study site. 


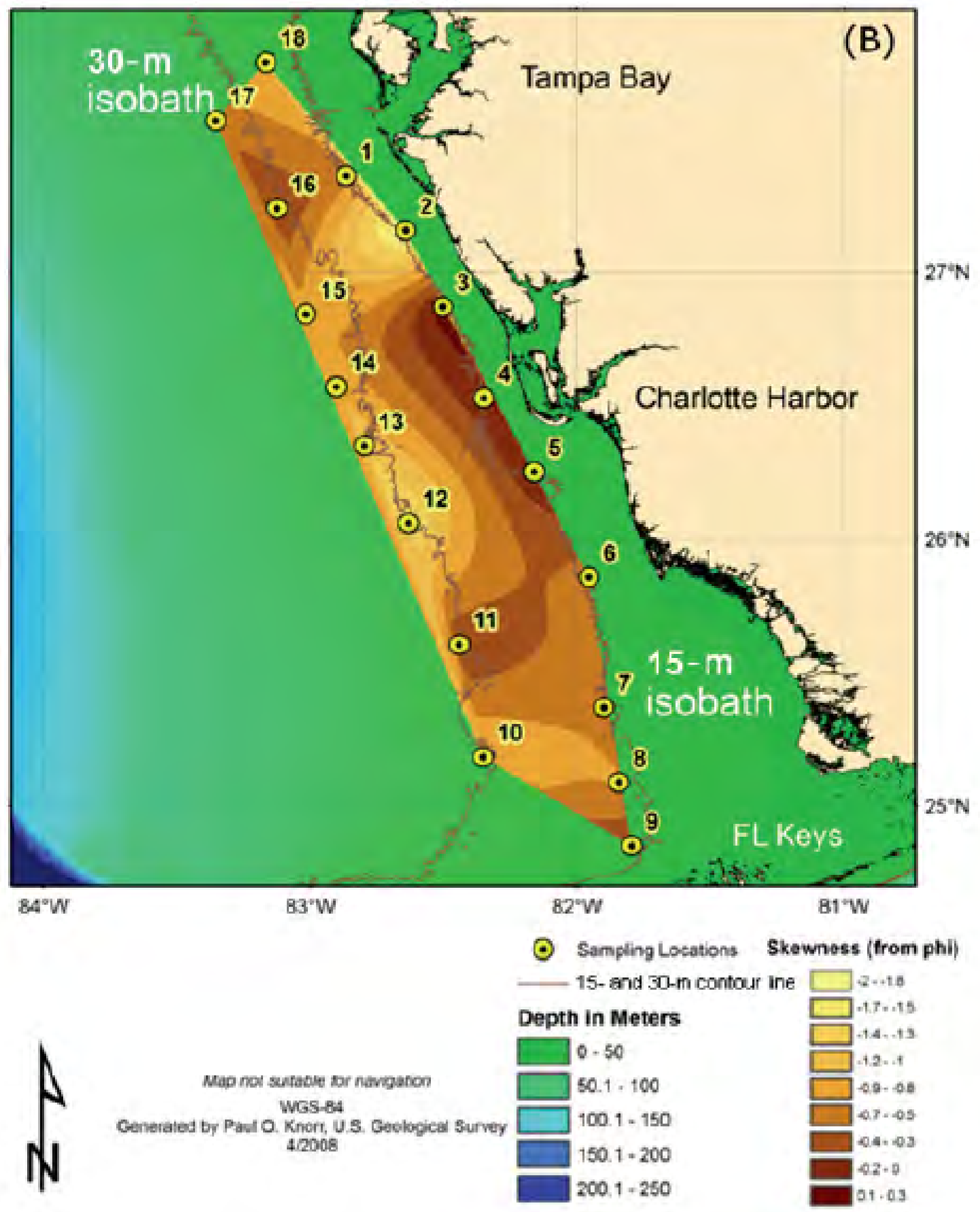

Figure 2.2 Maps of $A$, mean grain-size contours across the study site and $B$, skewness (based on moment method) contours across the study site. 
Sediment at all locations was predominantly sandsized with percentages ranging from 52 to 98 percent (table 2.2). Highest percentages were found closer to the coast along the $15-\mathrm{m}$ isobath and in proximity to the two main estuary systems, Tampa Bay and Charlotte Harbor (fig. 2.4). A higher content of coarse material, consisting of predominantly carbonate constituents, was found on both $15-\mathrm{m}$ and $30-\mathrm{m}$ isobaths. Coarse material was not found at locations with a

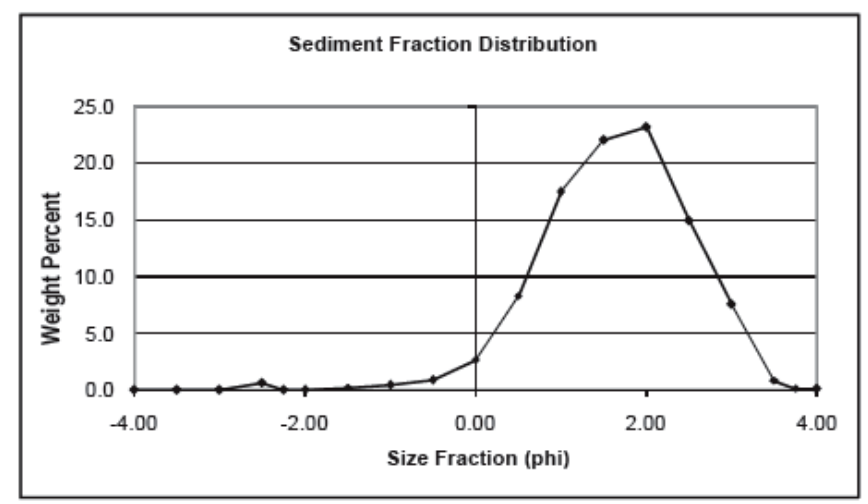

high mud percentage, with the exception of sample SC0408-9, which contained 29.5 percent mud and 4.3 percent gravel.

Significant amounts of mud were found at sites 02,09 , $10,11,15$, and 17 (table 2.1). Site 17, located off the Tampa Bay Estuary at the $30-\mathrm{m}$ isobath, is $>50 \mathrm{~km}$ off Egmont Key and is therefore out of depositional reach of estuarine sediments. Sites 02 and 15, located at the $15-\mathrm{m}$ and $30-\mathrm{m}$ isobaths, respectively, are offshore Venice Beach. Sites 09 and 10 , located at the $15-\mathrm{m}$ and $30-\mathrm{m}$ isobaths, respectively, are

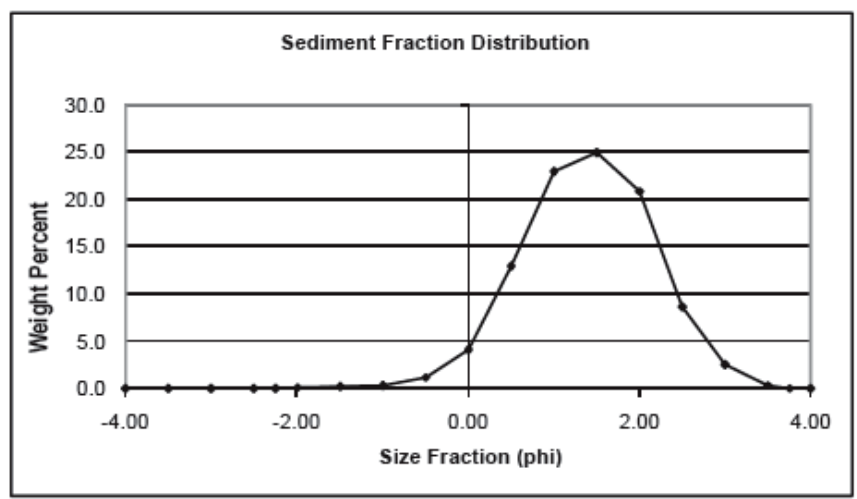

Figure 2.3 Example of typical sediment-fraction distribution (left); all samples, except at site SC0408-3 (right), are negatively skewed or strongly coarse-skewed.

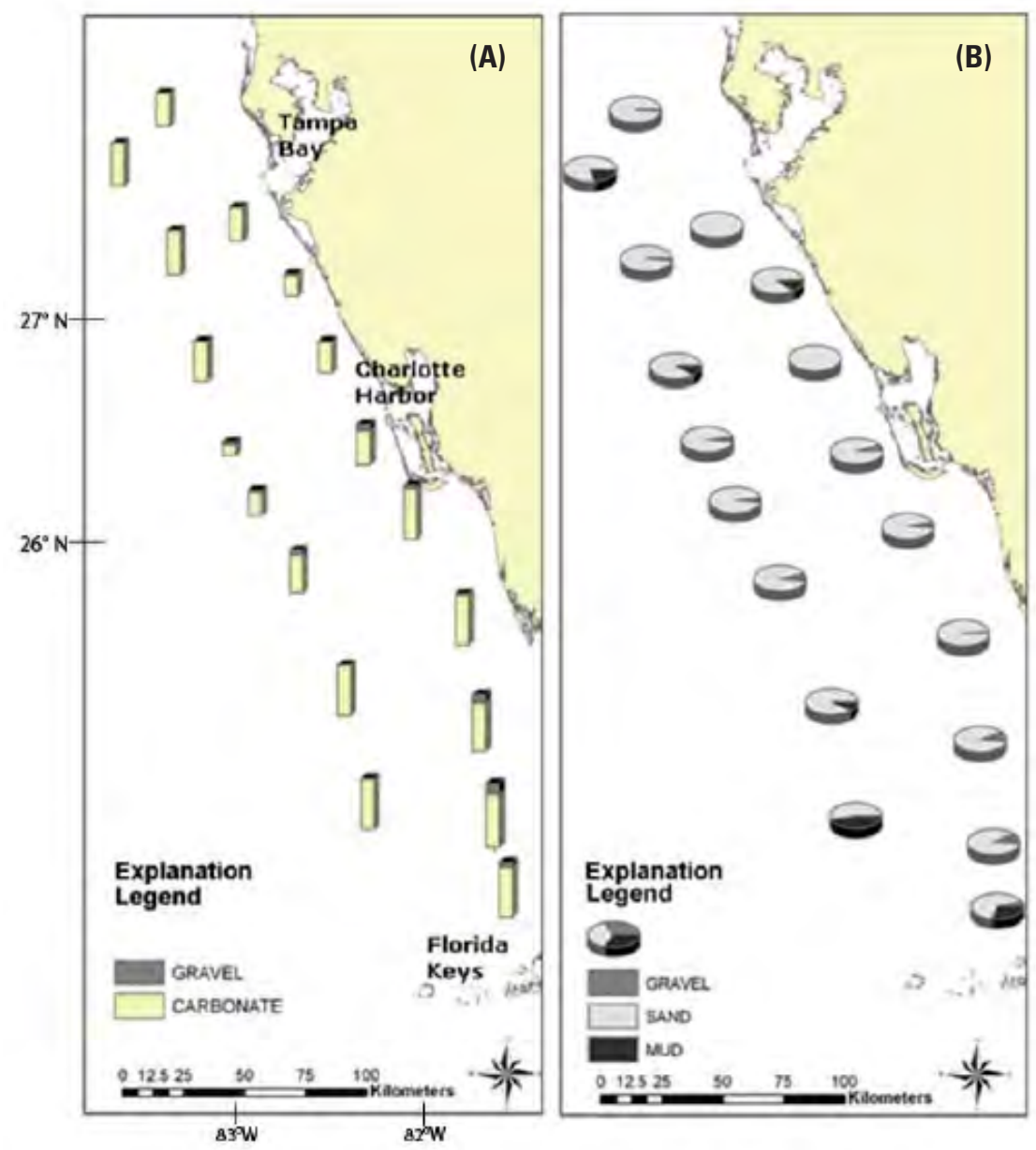

Figure 2.4 Representation of $A$, gravel and carbonate percent for each sample site and $B$, illustration of the gravel, sand, and mud percentage for each sample site. 
well within the bounds of the south Florida carbonate platform. Sample SC0408-11 (30-m isobath) as well as samples SC0408-09 and SC0408-10 were noted in the field as containing a significant amount of lime mud.

\section{Discussion}

It is assumed that the size and sorting of grains reflect the modes of sedimentation and depositional conditions. Therefore, grain-size data are important for environmental interpretation, as well as for discussing sediment sources and sinks, cycles, and sediment budgets (Boggs, 1987). Brooks and others (2003) found that south of Anna Maria Island, carbonate-rich sediment dominates and quartz-rich sediment is scarce. However, on a kilometer scale, sediment distribution varies significantly with respect to carbonate percent, and only on a regional scale $(>10 \mathrm{~km})$ is there a notable trend. Brooks and others (2003) found that the pattern is subtle.

The largest variance in mean grain size, found from site to adjacent site, is located between the two main estuaries (significant sources of sediment) (fig. 2.2B). Variance around the Tampa Bay Estuary at nearshore $(15-\mathrm{m})$ isobaths is observed in both the mean value and the variance of the skewness of adjacent sites. Both reflect significant regional differences in mud percentage as well as in gravel to coarse sand percentages. This variance represents the transition from nearshore sediment sources to offshore, and an overall latitudinal transition from a heterozoan, mixed siliciclastic and carbonate facies to a photozoan-carbonate facies.

Distribution and sorting of sediments found north of sites 09, 10, and 11 compare well with results of sediment analysis of the west Florida shelf by Brooks and others (2003). A sedimentalogical model presented by Brooks and others (2003) describes the west-central Florida inner shelf as containing carbonate-producing biota, nearby ancient quartz-sand deposits, and the underlying limestone platform. Because west Florida is a low-energy microtidal coast with mean annual wave heights of 25-30 centimeters (cm) (Tanner 1960; Davis 1989), tidal and wave processes are ineffective at redistributing sediment. The lack of dominance of these two elements, as well as the various sediment sources, is reflected in the variance in sediment type as well as in the spatial distribution.

\section{Conclusions}

The west Florida inner shelf is characteristic of a complex mixed siliciclastic and carbonate system. The latitudinal transition from warm temperate to subtropical water is reflected in the sediment transition from mixed to a carbonate assemblage with a high mud proportion (fig. 2.4). Sediment distribution from the nearshore isobath $(15 \mathrm{~m})$ to the deeper isobath $(30 \mathrm{~m})$ is reflected in decreasing mean sediment grain size and a significant variance of grain size around the two major estuarine systems, Tampa Bay and Charlotte Harbor. Sediment results compare well with those of previous studies and follow current sedimentological models for the west Florida shelf (Brooks and others 2003).

\section{References Cited}

American Society for Testing and Materials, 1989, Standard test method for particle size analysis of soils, Designation D 422-63, Annual Book of ASTM Standards: Philadelphia.

Boggs, S., Jr., 1987, Sedimentary textures, in, eds., Principles of sedimentology and stratigraphy: Englewood Cliffs, NJ, Prentice-Hall, p. 64-71.

Brooks, G.R., Doyle, L.J., Davis, R.A., DeWitt, N.T., and Suthard, B.C., 2003, Patterns and controls of surface sediment distribution: West-central Florida inner shelf: Marine Geology, v. 200, p. 307-324.

Davis, R.A., Jr., 1989, Morphodynamics of the west-central Florida barrier system: The delicate balance between waveand tide-domination, in, eds., Coastal Lowlands, Geology and Geotechnology: Dordrecht, Kluwer, p. 225-235.

Folk, R.L., 1965, Some aspects of recrystallization in ancient limestones, in Pray, L.C., and Murray, R.C., eds., Dolomitization and limestone diagenesis: SEPM Special Publication 13: Tulsa, OK, Society of Economic Paleontologists and Mineralogists, p. 14-48.

Folk, R.L., 1974, Petrology of sedimentary rocks: Austin, TX, Hemphill, 182 p.

Tanner, W.F., Jr., 1960, Florida coastal classification: Transactions, Gulf Coast Association of Geological Societies, v. 10, p. 259-266.

Wright, L.D., 1995, Morphodynamics of inner continental shelves: Boca Raton, FL, CRC Press, 241 p. 


\title{
Section 3. Assessing Carbonate and Total Organic Content Trends in Sediments on the West Florida Shelf
}

\author{
By Patrick Schwing ${ }^{1}$
}

\section{Introduction}

The west Florida shelf is a carbonate platform that is $900 \mathrm{~km}$ long and ranges from $25 \mathrm{~km}$ to $250 \mathrm{~km}$ wide (Hine and others, 2008). The platform, commonly referred to as the Florida Platform, began to form during the Jurassic period (199-145 million years ago, Ma). Carbonate production ceased in the Oligocene due to the rejuvenation of the Appalachian orogeny, which caused a huge influx of terrigenous sediment onto the platform (Hine and others, 2008). The shelf trends north to south from a ramp to ridge morphology and includes sections of homoclinal and distally steepening morphologies. With a large carbonate platform, the bathymetry in this area is primarily controlled by large- and small-scale karstic collapses upon subsurface dissolution of the carbonate material. Large-scale features, such as the Tampa Bay and Charlotte Harbor estuaries, and small-scale features, such as ledges (scarps on the west-central shelf) are all in some way a result of karstic collapse (Obrochta and others, 2003; Hine and others, 2008).

The sedimentary setting on the west Florida shelf has two dominant trends:

1. From north to south is a transition from terrigenous siliciclastic dominance to carbonate dominance, and

2. From east to west (onshore to offshore) is a transition from relict siliciclastic dominance to carbonate dominance (Brooks and others, 2003; Hine and others, 2008).

The transition in the latter trend can be seen at about $30 \mathrm{~km}$ offshore, with seaward pulses of siliciclastic dominance at the mouths of the Tampa Bay and Charlotte Harbor estuaries (Brooks and others, 2003).

The subject of ocean acidification has gained more attention along with rising ocean temperatures especially since the publication of Kleypas and Langdon (2006). However, there have been relatively few studies that quantify the changes in ocean acidification and its effects on the carbonate biota.

The carbonate $\left(\mathrm{CO}_{3}\right)$ fraction of sediment samples on the west Florida shelf represents the amount of carbonate-shell production in the area. The west Florida shelf offers a natural laboratory for assessing the latitudinal changes in biocalcification and for identifying trends of carbonate material in the sediments.
Total organic content (TOC) of sediment samples on the west Florida shelf is an indicator of the amount of primary production in the area. TOC measurements indicate how nutrients are being utilized biogenically. Absorption of sunlight within the water column by photosynthetic organisms will also be reflected in TOC measurements from bottom sediments. The objective of this study is to determine the amount of calcium carbonate and TOC within sediment grab samples and to relate these trends to the transition from heterozoan to photozoan biota, productivity, and terrestrial influence.

\section{Methods}

Surface-sediment grab samples were taken from the west Florida shelf, April 1-4, 2008, at 18 sites along the 15-m and the 30-m isobaths using a Shipek grab sampler (fig. 1.2). Sediments from each site were washed with deionized water and dried in an oven at $105^{\circ} \mathrm{C}$ for 24 hours. About 1 gram of each dried sample was placed in a crucible and weighed. The samples were transported by desiccator to make sure the sediments were not affected by humidity. The samples were then put into a muffle furnace at $550{ }^{\circ} \mathrm{C}$ for 4 hours and weighed after cooling to determine the loss on ignition (LOI) of TOC using the following equation (DW= dry weight):

$$
\mathrm{LOI}_{550}=\left(\left(\mathrm{DW}_{105}-\mathrm{DW}_{550}\right) / \mathrm{DW}_{105}\right) * 100
$$

The samples were then placed in the muffle furnace for 1 hour at $1000{ }^{\circ} \mathrm{C}$ to determine the carbonate fraction by the following equation $(\mathrm{DW}=$ dry weight):

$$
\mathrm{LOI}_{1000}=\left(\left(\mathrm{DW}_{550}-\mathrm{DW}_{1000}\right) / \mathrm{DW}_{550}\right) * 100
$$

The LOI method was chosen over the acid-leaching method because the acid method can leach terrigenous clays as well. The effect overestimates the amount of carbonate in the sample (Dean, 1974; Heiri and others, 2001).

\section{Results}

The carbonate values from all samples were lower than values in previous studies conducted on the west Florida shelf.

${ }^{1}$ University of South Florida College of Marine Sciences, 140 7th Ave. South, St. Petersburg, FL 33701 

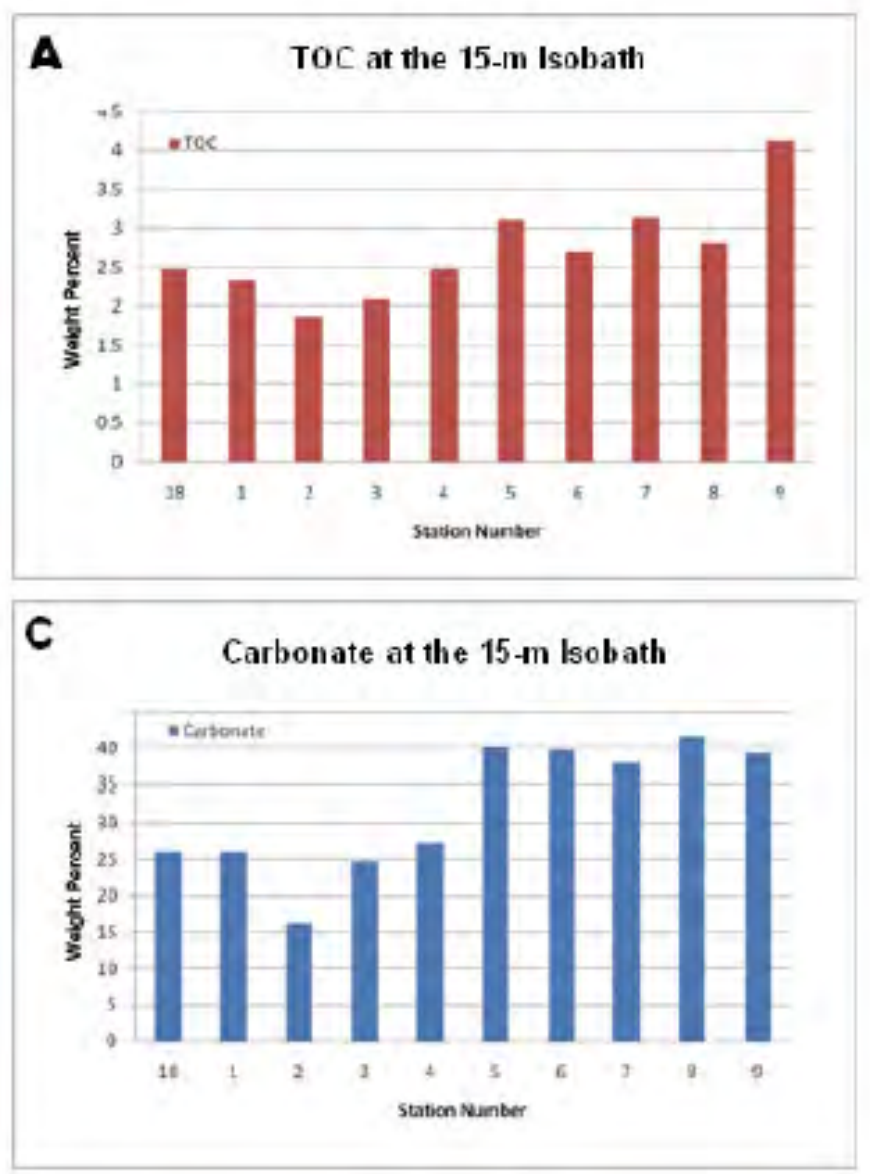
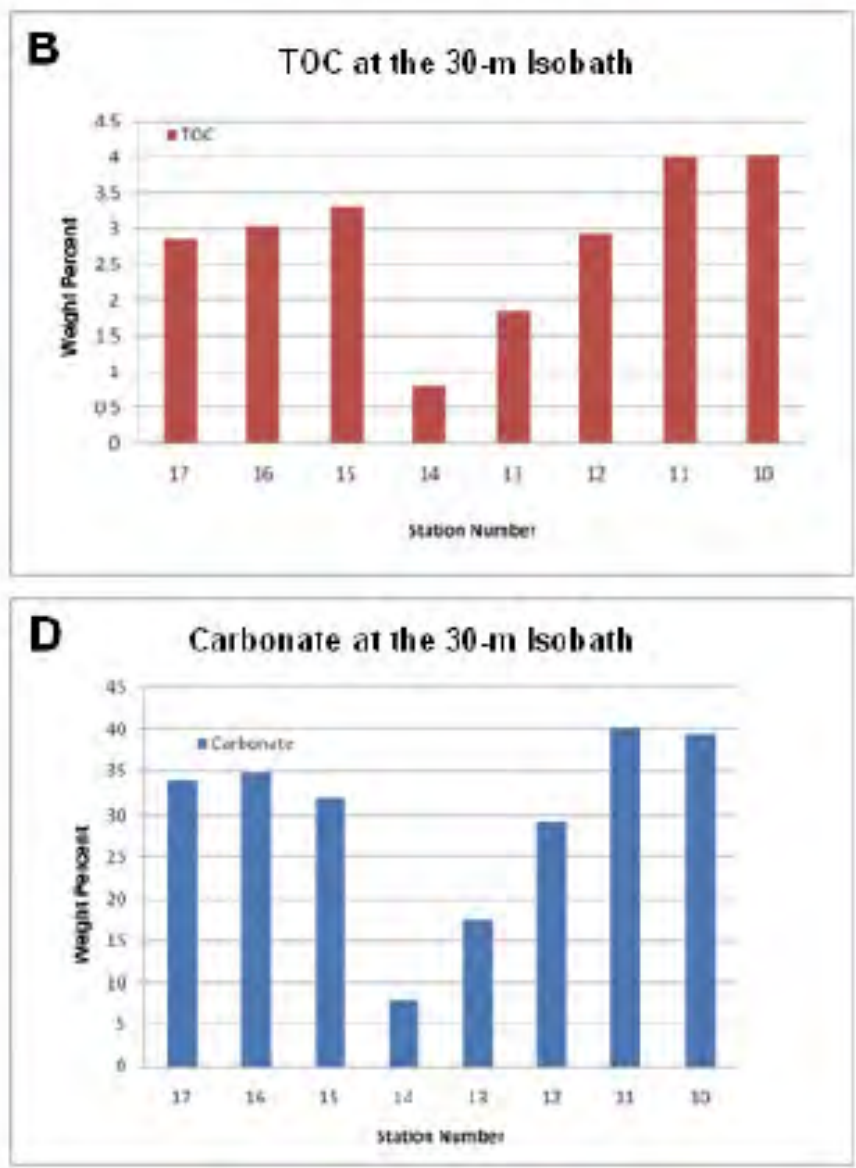

Figure 3.1 Calcium carbonate and total organic content (TOC) weight percentages at the 15-m and 30-m isobaths arranged from north to south (along the $\mathrm{x}$-axis) showing the low amounts of carbonate and the rapid decrease-gradual increase trend from north to south.

The average values at the $15-\mathrm{m}$ and $30-\mathrm{m}$ isobaths were 31.9 weight percent and 29.4 weight percent, respectively (fig. 3.1A-D). The highest carbonate-weight percentage recorded was 41.4 weight percent at site 8 . In earlier studies, Brooks and others (2003) determined there were several sites with a carbonate fraction above 80 weight percent, and Force (1969) determined there were many nearshore sites that had a carbonate composition of well over 50 weight percent (figs. 3.2 and 3.3).

Overall, the carbonate fraction was lower in the north and higher in the south along both isobaths, as expected (fig. 3.4). The northern 15-m isobath sites SC0408-18 and SC0408-01 both had 26.1 weight percent carbonate, whereas the southern 15-m-isobath sites SC0408-08 and SC0408-09 had 41.5 and 39.3 weight percent carbonate, respectively. The northern 30-m-isobath sites SC0408-17 and SC0408-16 had values of 33.9 and 34.9 percent carbonate, respectively, while the southern 30-m-isobath sites SC0408-11 and SC0408-10 had carbonate percentages of 40.0 and 39.4 percent, respectively. The increase in the carbonate fraction from north to south was greater along the 15-m isobath than along the $30-\mathrm{m}$ isobath.
TOC was also generally lower to the north and higher to the south. The northern 15-m-isobath sites SC0408-18 and SC0408-01 had 2.5 and 2.3 percent TOC, whereas the southern 15-m-isobath sites SC0408-08 and SC0408-09 had 2.8 and 4.1 percent TOC, respectively. The northern $30-\mathrm{m}$-isobath sites SC0408-17 and SC0408-16 had values of 2.9 and 3.0 percent TOC, respectively, while the southern $30-\mathrm{m}-$ isobath sites SC0408-11 and SC0408-10 both had TOC percentages of 4.0 percent.

The trend that dominated both the carbonate and TOC fraction from north to south was the rapid decrease in both constituents between sites SC0408-01 (26.1\% $\mathrm{CO}_{3}, 2.3 \%$ TOC) and SC0408-02 (16.2\% $\mathrm{CO}_{3}, 1.9 \%$ TOC) along the 15-m isobath and between sites $\mathrm{SC} 0408-15$ (32.0\% $\mathrm{CO}_{3}$, $3.3 \%$ TOC) and SC0408-14 (7.9\% $\mathrm{CO}_{3}, 0.8 \%$ TOC) along the $30-\mathrm{m}$ isobath. This rapid decrease was followed from north to south by a gradual increase over the next three sites (SC040803, 04, 05) along the 15-m isobath and (SC0408-14, 13, 12) along the $30-\mathrm{m}$ isobath (fig. 3.1A-D).

With regards to the rapid decrease and gradual increase of both constituents on both isobaths from north to south, one major discrepancy occurred between the records of each isobath. The rapid decrease and gradual increase trend observed 


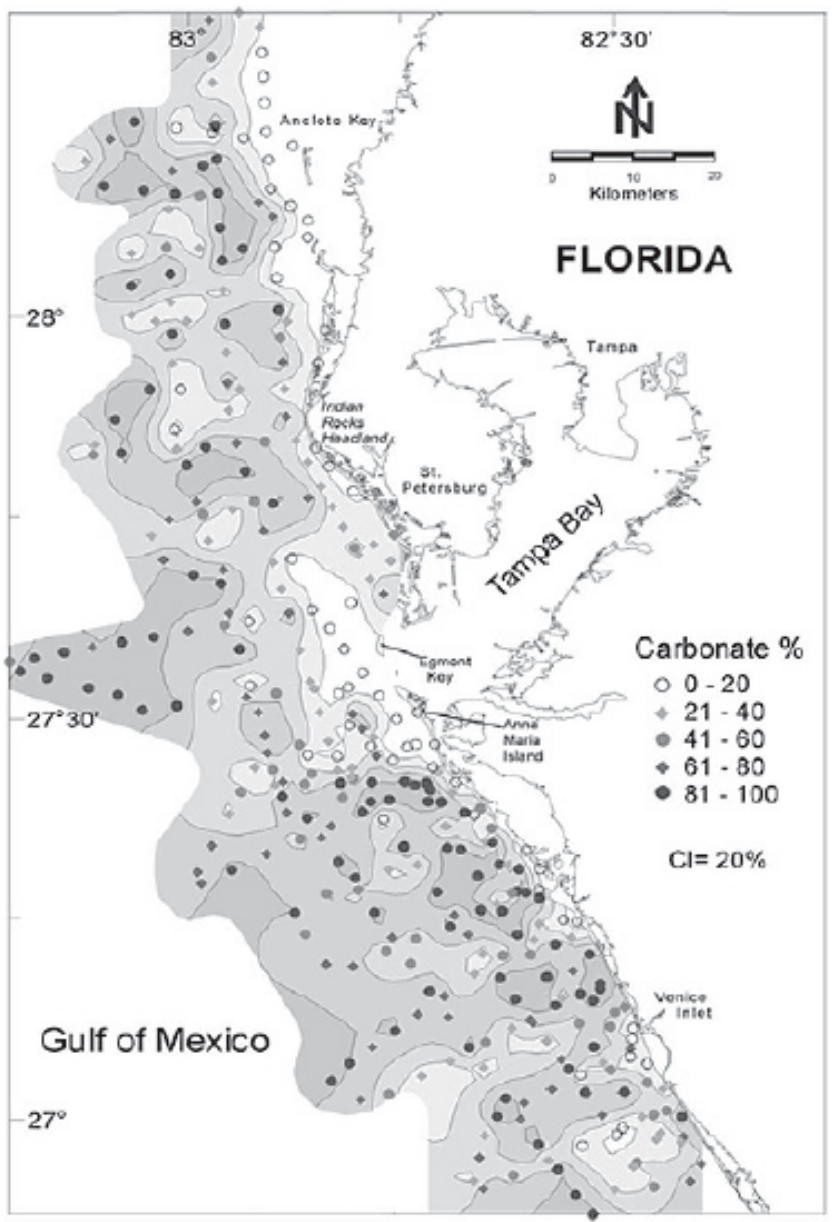

Figure 3.2 Tampa Bay area showing higher carbonate values $(>80 \%)$ in the southern part (versus northern part) of the study area (contour interval $(\mathrm{Cl})$ is $20 \%$ carbonate) (modified from Brooks and others, 2003).

Figure 3.3 Nearshore area near Sarasota showing carbonate values of up to $93 \%$ (modified from Force, 1969).

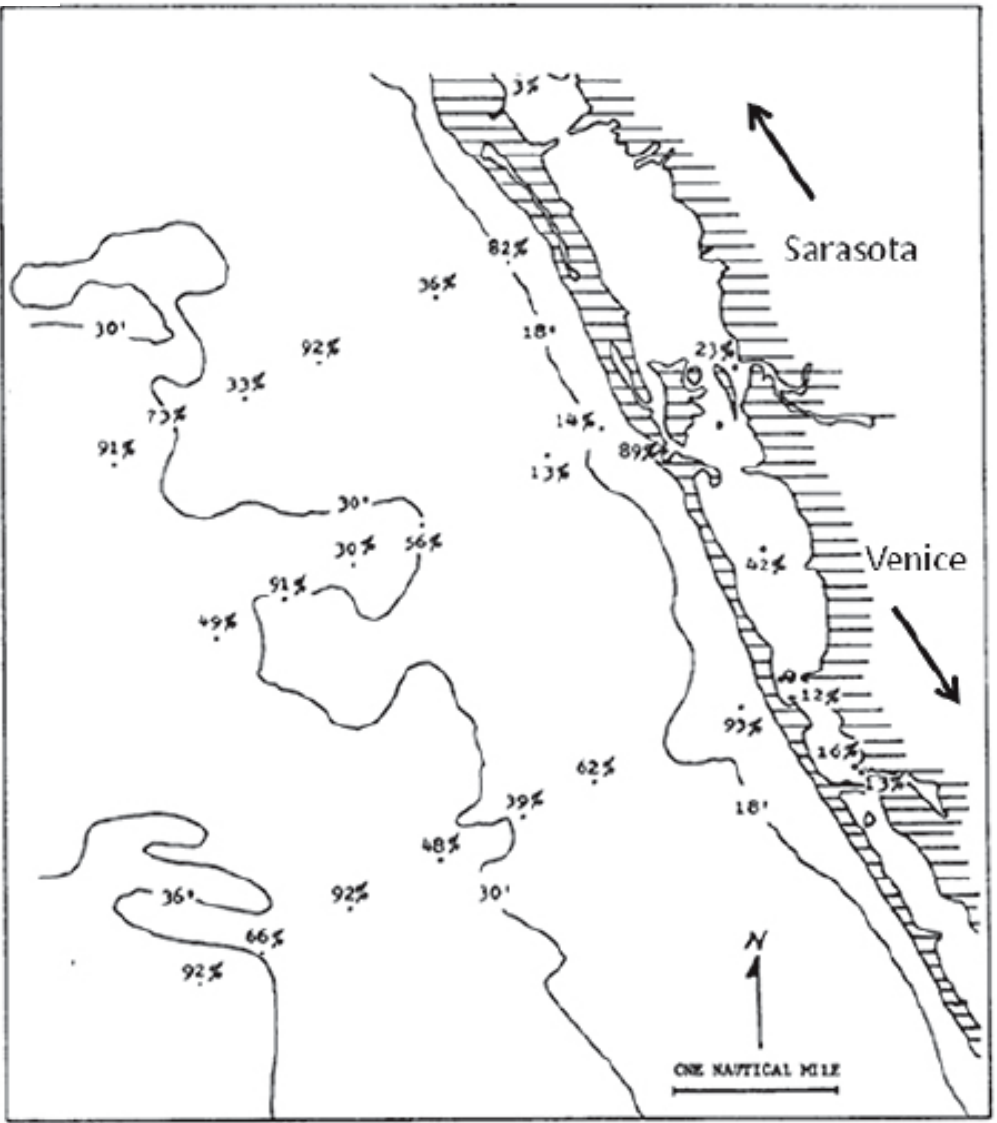




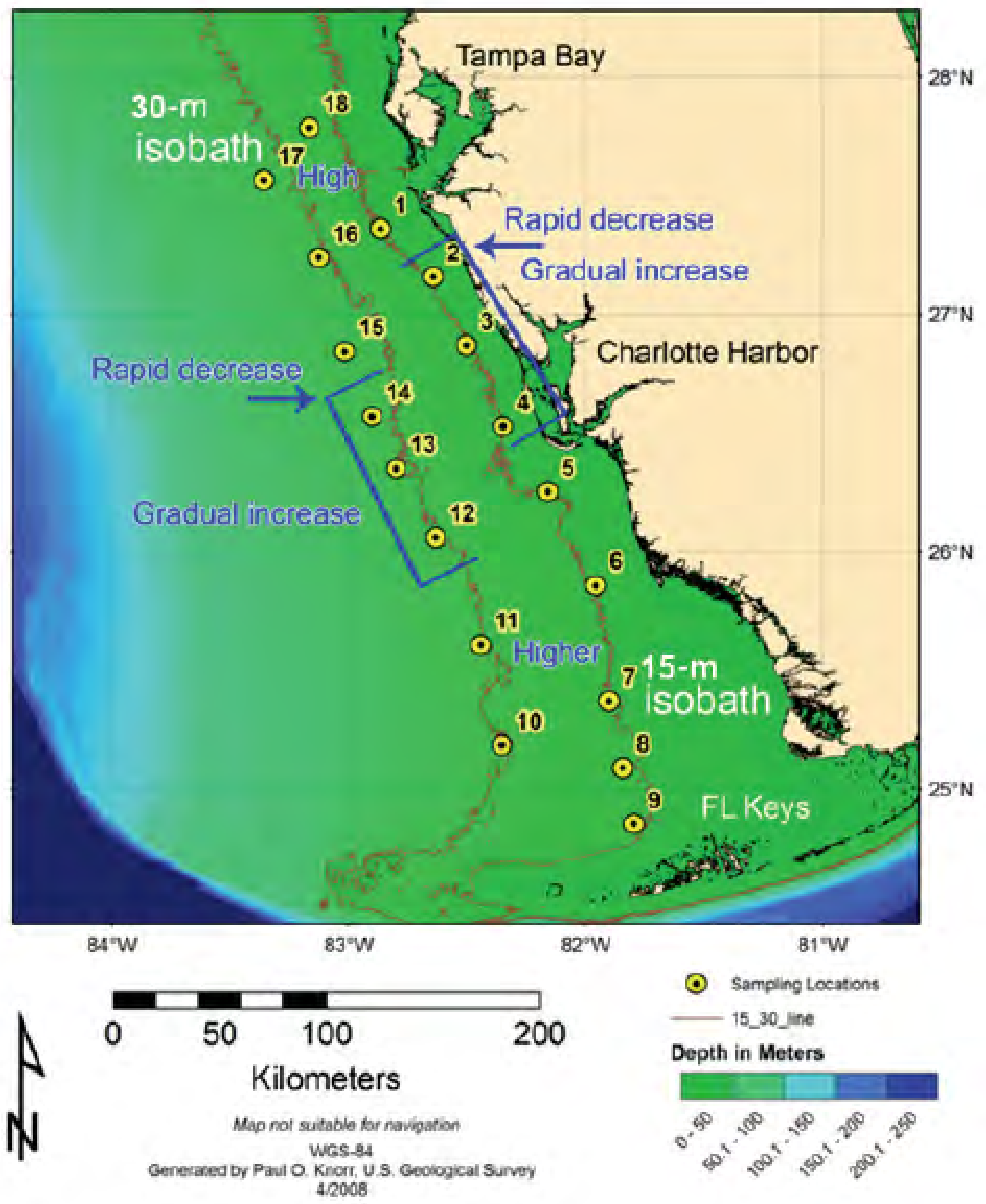

Figure 3.4 West Florida shelf including samples with brackets denoting the rapid decrease to gradual increase trend from north to south. Note north offset of the trend at the $15-\mathrm{m}$ isobath and south offset along the $30-\mathrm{m}$ isobath. 


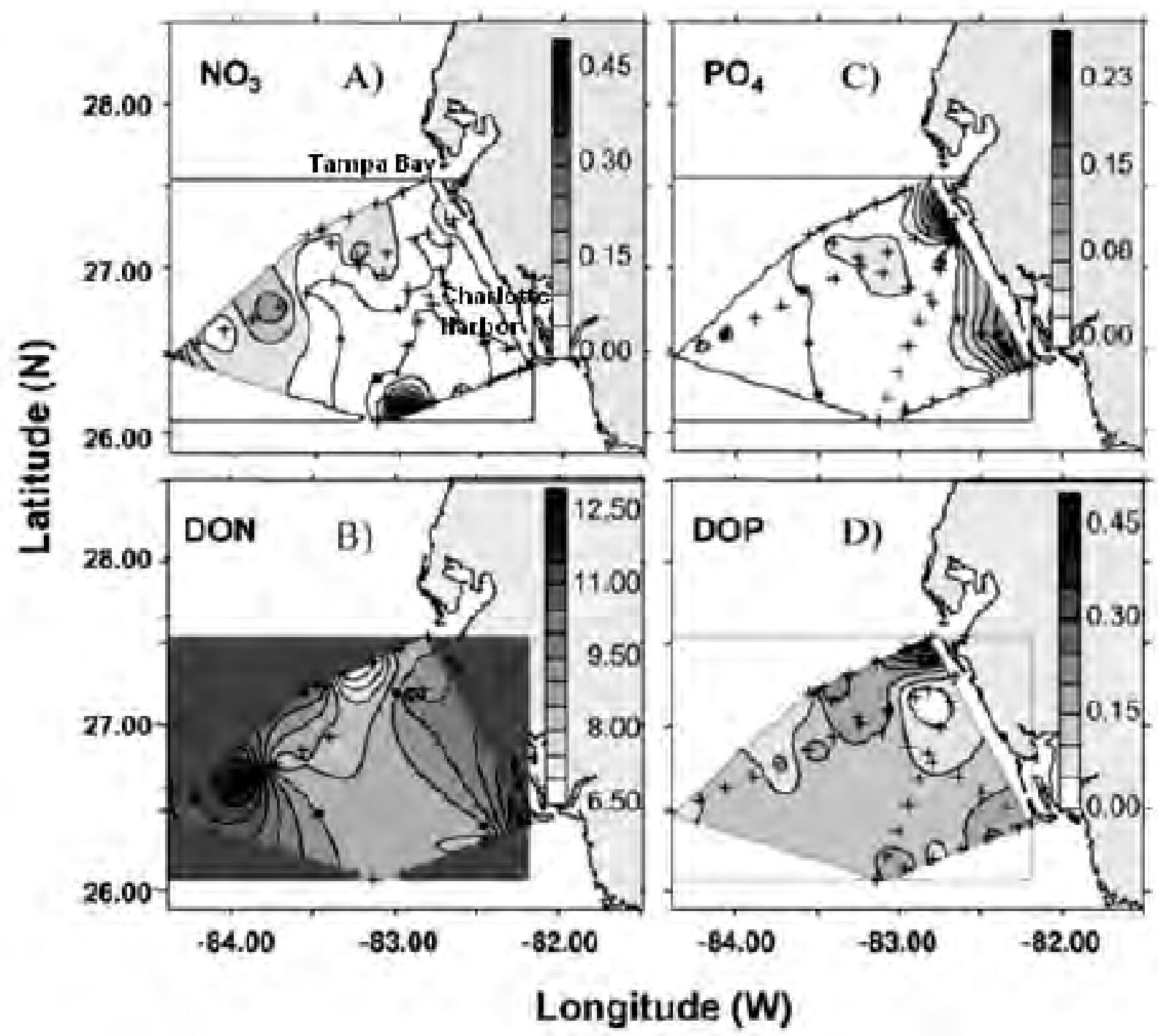

Figure 3.5 Nitrate $\left(\mathrm{NO}_{3}\right) /$ dissolved organic nitrate $(\mathrm{DON})$ and phosphate $\left(\mathrm{PO}_{4}\right) /$ dissolved organic phosphate (DOP) profiles from the west Florida shelf show a rapid decrease and gradual increase from north to south as observed in the TOC and carbonate percentages from the 15-m isobath (modified from Walsh and others, 2006). 


\section{Florida Topography and Bathymetry for West FLorida Shelf Cruise SC0408}
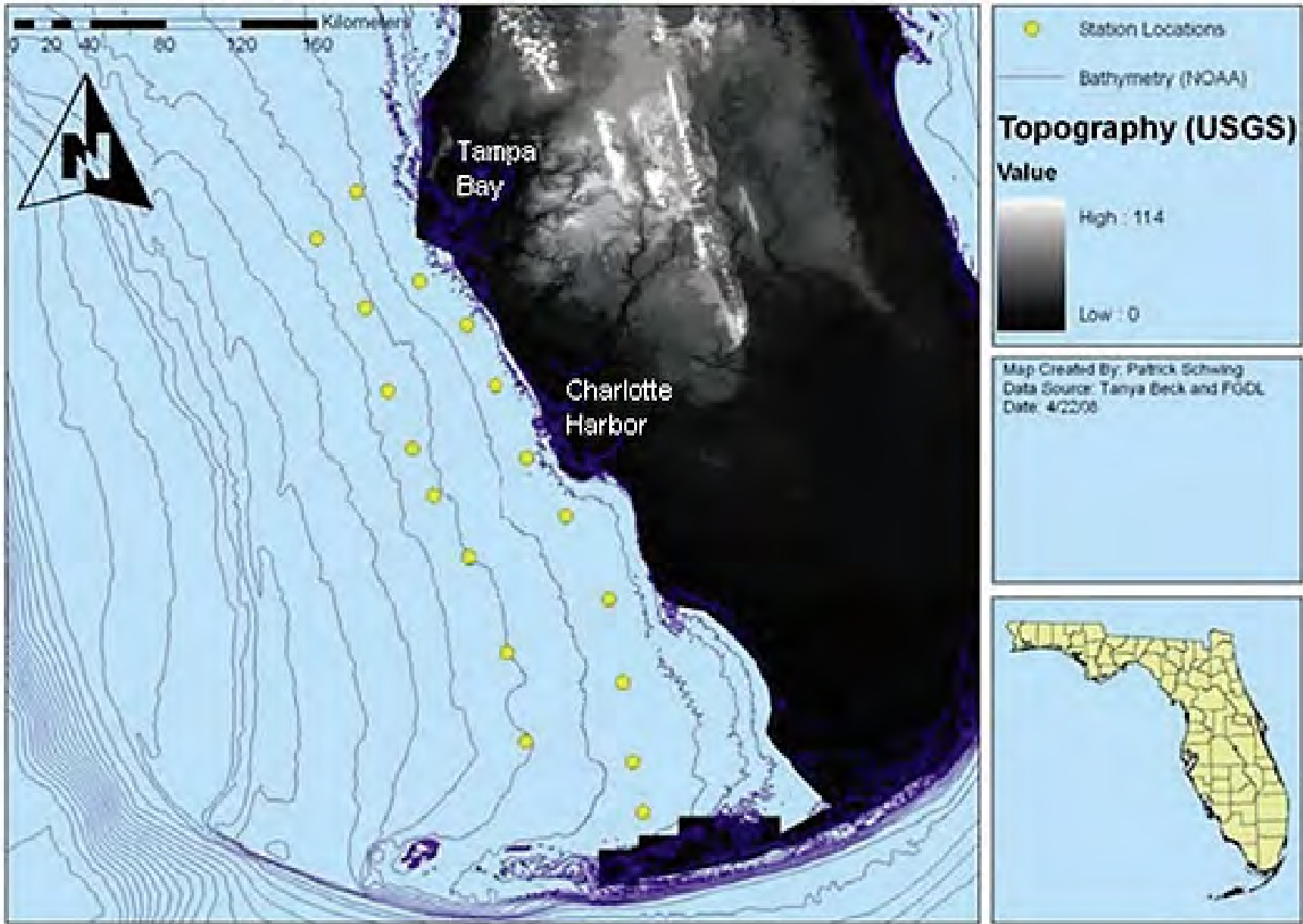

Hop Creatid Dy. Parick Echaing

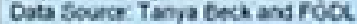
Date 4 Faso

Figure 3.6 Map of sample sites (yellow dots) and their locations relative to the southwest-striking topographic and bathymetric high between Tampa Bay and Charlotte Harbor Estuaries. Bathymetric base map from Robbins and others (2007).

in the 15-m-isobath samples was farther north than that of the trend observed along the 30-m-isobath (fig. 3.4).

\section{Discussion}

The low percentage of carbonate material observed in the samples could have been controlled by two factors: (1) less carbonate production on the west Florida shelf than previously observed, or (2) different analytical methods and lack of analysis of replicate samples leading to differing results. It is unlikely that there was far less carbonate production than previously found. Also, replicate samples need to be run through the LOI method to determine repeatability. This study used different methodology (LOI) than previous comparative studies (acid leaching), and it would be beneficial to analyze these samples by acid leaching. It is more likely that different methodologies led to the discrepancy. This can be resolved through further analysis.
The increase in the carbonate fraction from north to south was expected and was observed. However, a slightly higher increase was observed along the $15-\mathrm{m}$ isobath than along the $30-\mathrm{m}$ isobath. The higher increase was most likely due to influx of terrigenous sediment from the mouth of the Tampa Bay Estuary, diluting the carbonate fraction closer to shore.

The observed increase in TOC toward the south was not predicted and was expected to be most prevalent at the mouths of the Tampa Bay and Charlotte Harbor Estuaries. The observed southerly increase could be due to outwash of nutrients from the Everglades. The increase in nutrients could have caused more primary production and therefore more organic matter.

The rapid decrease to gradual increase trends observed in both constituents along both isobaths could be a result of several factors that ultimately will require more study. Sedimentary controls could produce such trends. Nutrient-profile changes along the sample transects would affect the TOC and carbonate productivity. A combination of a bathymetric high and currents that dominate the west Florida shelf might be an influence. Finally, the most convincing argument is that the 

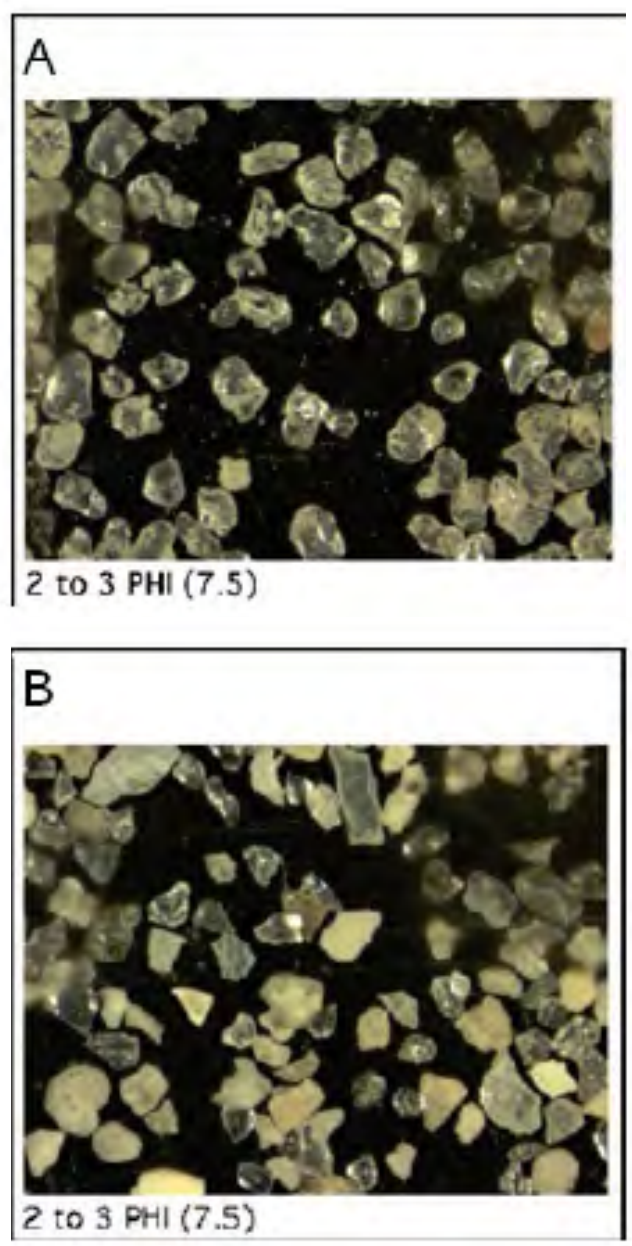

Figure 3.7 Microscope photographs showing dominant grain size at site $A, \mathrm{SCO} 0408-15$ and $B, \mathrm{SCO} 408-14$. The grains exhibit the dominant shift from carbonate to quartz (siliciclastic) material over the rapid-decrease trend. The 2 to $3 \Phi$ equals $7.5 \mathrm{~mm}$. (Photography by Rebekka Larson, University of South Florida College of Marine Sciences.)

trend in carbonate and TOC distribution is dominated by influx and deposition of siliciclastic material from either terrigenous sources or from longshore transport of barrier-island material.

The primary constituent of the two sites in which the decrease was observed was fine-grained quartz sand (see fig. 3.7). Dominance of quartz sand argues that the control on carbonate and TOC in sediments is simply the supply and distribution of siliciclastic material in the area. The distribution could be due to proximity of the terminus of the barrier-island system, and the longshore-transport system is simply washing the siliciclastic material from the barrier islands out to sea; on the other hand, this material maybe coming from a terrigenous source. The latter possibility is, however, unlikely in that previous studies have shown that terrigenous influence is very minimal on the west-central Florida shelf (Brooks and Doyle, 1998; Hine and others, 2008).

Nutrient profiles have been established for the west Florida shelf including profiles for phosphates, nitrates, and

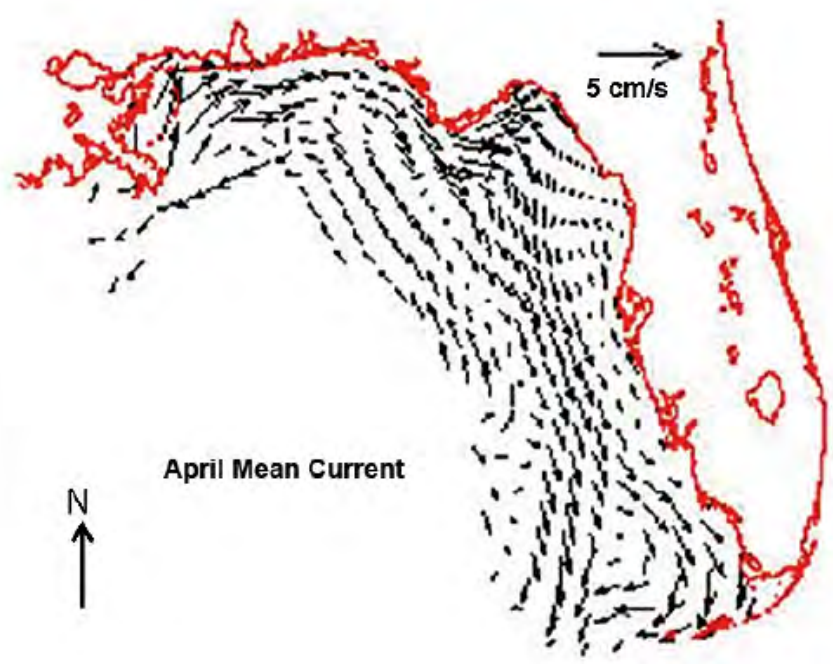

Figure 3.8 April mean current, magnitude, and direction shown by arrows in centimeters per second $(\mathrm{cm} / \mathrm{s})$ with $5 \mathrm{~cm} / \mathrm{s}$ arrow included for velocity reference (Weisberg, 2002).

others. The observed north-to-south trend in both TOC and carbonate can be explained at the $15-\mathrm{m}$ isobath by comparing the phosphate profile as presented in Walsh and others (2006) and the trends in both constituents (fig. 3.5). The highest percentages of TOC and carbonate are observed in the phosphate plume from Tampa Bay. The rapid decrease occurs just south of that plume, where very low phosphate levels are found. The gradual increase in both constituents also follows the gradual increase of phosphate from the Charlotte Harbor Estuary.

Bathymetry of the area and the currents that act upon that bathymetry may control sedimentation. A bathymetric low occurs over the expanse of the rapid decrease and gradual increase in both constituents, with the axis of the ridge striking near the area of rapid decrease (fig. 3.6). This scenario might cause an uneven distribution in the coarse-fraction carbonate material or the fine-fraction organic material.

The northerly offset in the $15-\mathrm{m}$ isobath trend of constituents' rapid decrease and gradual increase and the southerly offset in the 30-m-isobath trend also have possible controls: bathymetry, considering the southwestern strike of the bathymetric high, and, again, currents and siliciclastic dominance in the area.

The axis of the bathymetric high that occurs roughly at the same position as the observed decrease in carbonate and TOC extends from northeast to southwest (fig. 3.6). If bathymetry is the dominant control, then the trends would be expected to be situated farther north landward and farther south seaward.

Assuming siliciclastic dominance in the sediments at these sites due to nearby terminus of the longshore-transport system, the most probable process that would produce an offset in carbonate and TOC values would be the predominant currents in the area during April controlling deposition of siliciclastics (fig. 3.8). A northerly boundary current along the coast would force the siliciclastics northward initially, thus 
providing the rapid decrease and gradual increase in carbonate and TOC along the $15-\mathrm{m}$ isobath. However, as the siliciclastic sediment is swept seaward, a dominant southerly flow would produce the same trends in carbonate and TOC along the $30-\mathrm{m}$ isobath farther south.

\section{Conclusions}

1. The observed carbonate values in this study were very low as compared with results of previous studies, and this is most likely due to methodological differences. Future studies should run replicates of the samples through LOI analysis as well as employ the acid-leaching technique. However, overall trends in the carbonate data are reliable, since they are not affected by the methodological differences.

2. Nutrient profiles along the $15-\mathrm{m}$-isobath sites show a definite correlation with the rapid decrease and gradual increase of both TOC and carbonate. Phosphates may be a control on the TOC of sediments along the $15-\mathrm{m}$ isobath.

3. The rapid decrease - gradual increase trends in both constituents along the $15-\mathrm{m}$ and $30-\mathrm{m}$ isobaths from north to south are most likely due to a dominant siliciclastic influx from the end of the longshoretransport system that is being influenced by bathymetry and currents.

4. The offset of the rapid decrease - gradual increase trends in carbonate and TOC to the north along the $15-\mathrm{m}$ isobath and to the south along the $30-\mathrm{m}$ isobath are most likely due to an interaction of siliciclastic sediment transport with the northern boundary current and dominant southerly flow observed in April along the west Florida shelf.

\section{References Cited}

Brooks, G.R., and Doyle, L.J., 1998, Recent sedimentary development of Tampa Bay, Florida: A microtidal estuary incised into Tertiary platform carbonates: Estuaries, v. 21, p. 391-406.

Brooks, G.R., Doyle, L.J., Davis, R.A., DeWitt, N.T., and Suthard, B.C., 2003, Patterns and controls of surface sediment distribution: West-central Florida inner shelf: Marine Geology, v. 200, p. 307-324.
Dean, W.E., Jr., 1974, Determination of carbonate and organic matter in calcareous sediments and sedimentary rocks by loss on ignition: Comparison with other methods: Journal of Sedimentary Petrology, v. 44, no. 1, p. 242-248.

Force, L.M., 1969, Calcium carbonate size distribution on the west Florida shelf and experimental studies on the microarchitectural control of skeletal breakdown: Journal of Sedimentary Petrology, v. 39, no. 3, p. 902-934.

Heiri, O., Lotter, A.F., and Lemcke, G., 2001, Loss on ignition as a method for estimating organic and carbonate content in sediments: Reproducibility and comparability of results: Journal of Paleolimnology, v. 25, p. 101-110.

Hine, A.C., Halley, R.B., Locker, S.D., Jarrett, B.D., Jaap, W.C., Mallinson, D.J., Ciembronowicz, K.T., Ogden, N.B., Donahue, B.T., and Naar, D.F., 2008, Coral reefs, present and past, on the west Florida shelf and platform margin, in Reigl, B., and Dodge, R.E., eds., Coral reefs of the U.S.A.: Netherlands, Springer, p. 127-173.

Kleypas, J.A., and Langdon, Chris, 2006, Coral reefs and changing seawater carbonate chemistry, in Phinney, J.T., Hoegh-Guldberg, O., Kleypas, J., Skirving, W., and Strong, A., eds., Coral reefs and climate change: Science and Management: Coastal and Estuarine Studies: Washington, DC, American Geophysical Union, Monograph Series, v. 61, p. $73-110$.

Obrochta, S.P., Duncan, D.S., and Brooks, G.R., 2003, Hardbottom development and significance to the sedimentstarved west-central Florida inner continental shelf: Marine Geology, v. 200, p. 291-306.

Robbins, L.L., Hansen, Raabe, Ellen, Knorr, Paul, and Browne, J., 2007, Cartographic Production for the Florida Shelf Habitat (FLaSH) Map Study: Generation of Surface Grids, Contours, and KMZ files: U.S. Geological Survey Open-File Report 2007-1397, 11 p.

Seibel, B.A., and Fabry, V.J., 2003, Marine biotic response to elevated carbon dioxide: Advances in Applied Biodiversity: Science, v. 4, p. 59-67.

Walsh, J.J., Jolliff, J.K., Darrow, B.P., and others, 2006, Red tides in the Gulf of Mexico: Where, when, and why?: Journal of Geophysical Research, v. 111, no. C11003, doi:10.1029/2004JC002813.

Weisberg, R.H., 2002, West Florida shelf: Physical oceanography [presentation]: HyCODE P.I. Meeting, accessed on May 8, 2009, at http://www.opl.ucsb.edu/hycode/pubs/hycode02/ weisberg.ppt. 


\title{
Section 4. West Florida Shelf: A Foraminiferal Perspective
}

\author{
By Michael Martínez-Colón'
}

\section{Introduction}

The west Florida shelf is a mixed carbonate-siliciclastic environment ranging from warm temperate to subtropical environments. Despite the variable landscape, foraminiferal assemblages from 18 surface grab samples contain a relatively low diversity. Miliolids are the most abundant forms found in the samples commonly dominated by Quinqueloculina species. Spatial distribution shows that the assemblages are governed by media grain size, mud content, and possibly depth. Larger benthic foraminifers are more abundant off the Tampa Bay area and decrease in abundance toward the south, into the Florida Bay area, where smaller benthic foraminifers predominate.

Anthropogenic input of $\mathrm{CO}_{2}$ into the atmosphere and subsequent incorporation of $\mathrm{CO}_{2}$ into the oceans is a worldwide phenomenon. This excess greenhouse gas promotes lowering of the $\mathrm{pH}$ of the oceans, and as a consequence, organisms, such as corals, may not be able to maintain skeletal structure. Photozoans, photosymbiotic organisms that depend on seawater carbonate chemistry, are at risk of not being able to calcify properly (Hallock, 2005), a risk that would hinder their survival rate.

The west-central Florida shelf (fig. 1.2) has a unique environmental setting. It is a sediment-starved mixed carbonate-siliclastic low-energy system (Obrochta and others, 2003) with a varied carbonate sediment composition, ranging from mollusk-dominated nearshore sediments coupled with abundant quartz (Brooks and others, 2003) to foraminifera- and pteropod-dominated sediments offshore (>600-m water depth) (Hine and others, 2008). The west Florida shelf provides an ideal natural laboratory in which to test latitudinal (and depth) shifts in habitat ranges of calcifying organisms (benthic foraminifera) due to ocean acidification.

Foraminifers are found in virtually all marine ecosystems that support eukaryotic life. Environmental factors include temperature, $\mathrm{pH}$, water motion, salinity, dissolved oxygen, turbidity, light intensity, and food supply. Substratum type, including sediment texture, biotic interactions, and taphonomic processes, affects the distribution of foraminiferal shells in benthic environments. Because of shell preservation in sediments, taxonomic diversity, wide distributions, abundances, small sizes, and relatively short reproductive cycles (Yanko and others 1999), benthic foraminifers can be extremely useful in assessing and monitoring of change in coastal and shelf environments. This report examines sediment samples collected from the west Florida shelf with the goal of assessing foraminiferal assemblages in relation to latitudinal and depth variations in order to better understand their ecological distribution.

\section{Methods}

\section{Site Description}

The west Florida shelf ( $\sim 900 \mathrm{~km}$ long and $25-250 \mathrm{~km}$ wide) ranges from a warm temperate climate in the north to a tropical climate south toward the Florida Keys (fig. 4.1) (Hine and Locker, in press). Along this gradient, carbonate sedimentation changes from predominantly animal-produced shell hashes known as heterozoan carbonates that accumulate at rates of centimeters per 1,000 years to subtropical reef environments, where photozoan carbonate sediments are produced in association with photosynthesis, at rates that can exceed a meter per 1,000 years (hypercalcification).

The west Florida shelf has been segmented into two main regions. Hine and Locker (in press) defines these regions as follows: (1) siliciclastic-dominated province (northwest shelfFlorida Panhandle), and (2) carbonate-dominated province (southwest-Florida peninsula) (fig 4.1). The realm inbetween these provinces is characterized by a NW to SE sediment transition in which sediments of this shallow, water-starved carbonate platform rest upon a Neogene hardbottom karstic surface (Hine and others, 2008; Hine and Locker, in press).

\section{Sample Collection and Processing}

Two sets of seafloor samples were collected with a Shipek grab sampler at 3-hour intervals (fig. 4.1). The first set (SC0408-1 to SC0408-9) was collected on a south-southwest trend along the west Florida shelf at approximately the $15-\mathrm{m}$ depth contour. The second set (SC0408-10 to SC0408-18) was collected on a north trend, approximately along the $30-\mathrm{m}$ depth contour.

Sediment samples were wet sieved using the $63-\mu \mathrm{m}$ mesh screen. The fraction $>63 \mu \mathrm{m}$ was used to pick the foraminifers under a binocular microscope, using a fine point brush. 


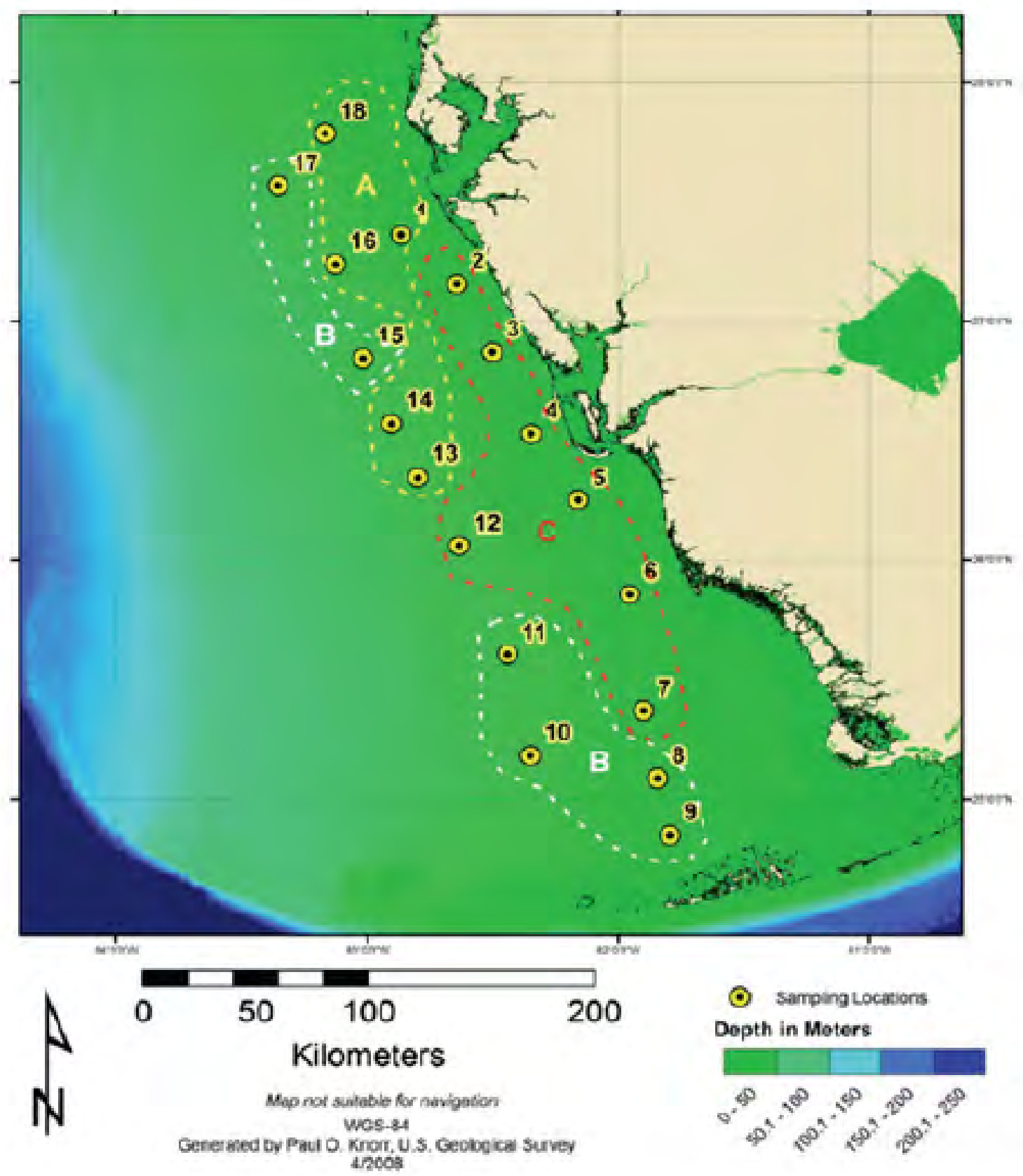

Figure 4.1 West Florida shelf study area. Dashed lines: theorized boundaries between assemblage distributions. $A, B$, and $C$ : sample distribution based on foraminiferal assemblages. (See text for assemblage information). Sample sites: yellow numbered dots. 


\section{Mathematical Approach}

Data were analyzed using the following statistical approaches that provided information on the ecological and environmental factors of the area under study:

1. Shannon-Weiner Index (H(S)) (Magurran, 1988):

$$
H(S)=-\sum p_{i}{ }^{*} \ln \left(p_{i}\right)
$$

The Shannon-Weiner index measures the heterogeneity of the samples and hence population over an area. It accounts for abundance and evenness in relation to the proportion of the $i^{\text {th }}$ species $\left(p_{i}\right)$, where $H$ is Shannon's Diversity Index, and $S$ is the total number of species in the community.

2. Equitability Index (E') (Magurran, 1988):

$$
E^{\prime}=e^{H(S)} / S
$$

The equability index measures the evenness based on $H(S)$ (as previously described) and the number of species $(S)$.

3. Fisher's Alpha Index (FAI) (Hammer and Harper, 2006):

$$
N / S=\left(e^{S / \alpha}-1\right) /(S / \alpha)
$$

Fisher's Alpha Index is a parameter of species richness which considers the ratio of sample size $(N)$ to number of species $(S)$ observed and generates a log-series distribution to predict the actual number of species present considering a proportionality constant $(\alpha)$.

\section{Statistical Approach}

Non-transformed Pearson's correlation matrix of percent carbonate, TOC, percent mud, percent sand, median grain size (D50), perecent foraminiferal morphogroups, latitude, and diversity indices was determined using the statistical software PRIMER (v. 6). This was done to determine the relation between biological and environmental data.

Two-way Q-mode cluster analyses (Ward's method) were performed using the PAST (v. 1.97) software package (Hammer and Harper, 2006). This approach, based on Euclidean distance, considers within-group variance. Analysis was done on foraminiferal species and sample stratification in order to determine assemblage correlation between samples.

\section{Results}

Total numbers of foraminiferal specimens per sample ranged from 8 to 232 (table 4.1) with highest values consistently occurring at the 30-m depth contour (app. 4.1).

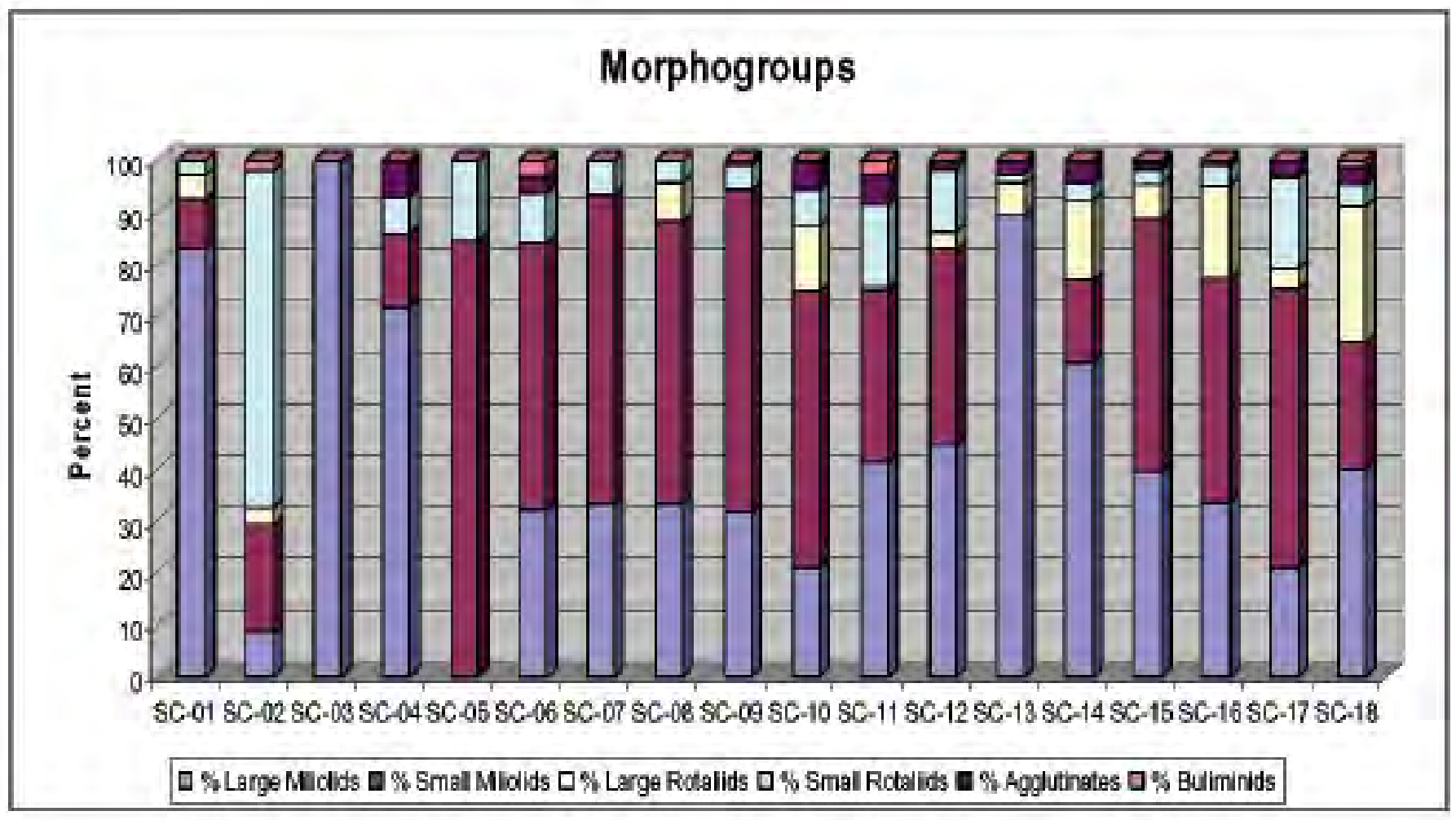

Figure 4.2 Foraminiferal morphogroup distributions, west Florida shelf. 
Table 4.1 West Florida shelf diversity indices. Yellow represents foraminiferal assemblage A; white represents assemblage $B$; red represents assemblage $C$.

\begin{tabular}{|c|c|c|c|c|c|}
\hline \multicolumn{6}{|c|}{ DIVERSITY INDICES } \\
\hline $\begin{array}{l}\text { Sample } \\
\text { number }\end{array}$ & $\begin{array}{l}\mathrm{N} \text { (Number of } \\
\text { individuals) }\end{array}$ & $\begin{array}{c}\text { S (Number of } \\
\text { species) }\end{array}$ & $\begin{array}{c}\text { Shannon-Weiner } \\
\text { Index } H(S)\end{array}$ & $\begin{array}{l}\text { Equitability } \\
\text { Index (E) }\end{array}$ & $\begin{array}{c}\text { Fisher's } \\
\text { Alpha } \\
\text { Index (FAI) }\end{array}$ \\
\hline SC0408-01 & 133 & 13 & 1.56 & 0.36 & 3.57 \\
\hline SC0408-02 & 95 & 15 & 2.21 & 0.61 & 4.99 \\
\hline $\mathrm{SC} 0408-03$ & 8 & 3 & 0.74 & 0.70 & 1.74 \\
\hline SC0408-04 & 14 & 4 & 0.90 & 0.61 & 1.87 \\
\hline SC0408-05 & 19 & 5 & 1.45 & 0.85 & 2.21 \\
\hline SC0408-06 & 31 & 12 & 2.06 & 0.65 & 7.18 \\
\hline SC0408-07 & 15 & 6 & 1.64 & 0.86 & 3.71 \\
\hline SC0408-08 & 93 & 12 & 1.88 & 0.54 & 3.67 \\
\hline SC0408-09 & 88 & 11 & 1.73 & 0.51 & 3.32 \\
\hline SC0408-10 & 232 & 26 & 2.82 & 0.65 & 7.51 \\
\hline SC0408-11 & 106 & 20 & 2.59 & 0.67 & 7.29 \\
\hline SC0408-12 & 58 & 13 & 2.12 & 0.64 & 5.21 \\
\hline SC0408-13 & 67 & 7 & 1.21 & 0.48 & 1.97 \\
\hline SC0408-14 & 138 & 18 & 2.12 & 0.46 & 5.53 \\
\hline SC0408-15 & 106 & 17 & 2.39 & 0.64 & 5.72 \\
\hline SC0408-16 & 163 & 18 & 2.41 & 0.62 & 5.17 \\
\hline SC0408-17 & 177 & 21 & 2.61 & 0.65 & 6.20 \\
\hline SC0408-18 & 144 & 20 & 2.33 & 0.51 & 6.31 \\
\hline
\end{tabular}

Table 4.2 Pearson correlation factors between foraminiferal morphogroups, physical parameters, and diversity indices.

[H(S), Shannon-Weiner Index; E', Equitability Index; FAI, Fisher's Alpha Index; D50, Gram size at which 50 percent of the sediment sample is finer than]

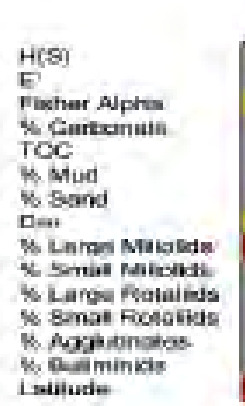

\begin{tabular}{|c|c|c|}
\hline$H(5)$ & $E^{\prime}$ & $\begin{array}{l}\text { Fisner } \\
\text { Aygrou }\end{array}$ \\
\hline 720 & & \\
\hline $\begin{array}{l}-0,22 \\
b 50\end{array}$ & $\begin{array}{r}100 \\
-0.02\end{array}$ & $\operatorname{LDO}$ \\
\hline n.23 & 0.49 & 0.20 \\
\hline 0.36 & 030 & 0.28 \\
\hline 0.49 & 001 & 0.39 \\
\hline 0.42 & -0.04 & -0.30 \\
\hline ara & 0.18 & ose \\
\hline & -0.46 & -0.45 \\
\hline $\mathrm{D}=3$ & $a ?$ & 0.24 \\
\hline 0.46 & -0.40 & 0.30 \\
\hline 0.24 & Q 17? & 0.17 \\
\hline 021 & $-0,4$ & 0.37 \\
\hline 033 & 0.07 & 0,56 \\
\hline & $\rightarrow$ a d $\mathrm{a}$ & $\rightarrow \mathrm{D}+6$ \\
\hline
\end{tabular}

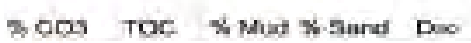

sc Large Alinubos

96 Bmak \% Large

simeil solaikets Rotaneses dencist Buter

Loimuste

\section{on} 1.04 $087 \quad 1.00$

Dor 100

$-0.36$

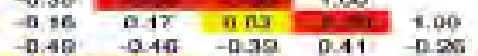

$\begin{array}{ccccc}-0.48 & -0.40 & -0.39 & 0.41 & -0.25 \\ 0.7 n & 0.07 & 0.34 & -0.40 & 0.04 \\ -0.21 & -0.21 & 0.02 & 0.04 & 0.35\end{array}$

$-0.27$

$-0.20$

0.08
0.04

$\begin{array}{llll}0.02 & 0.04 & 0.35\end{array}$

$\begin{array}{llll}1012 & 019 & 0.11 & 0.36\end{array}$

$\begin{array}{llll}006 & 0.24 & 0.21 & 0.2 d \\ 0.05 & 11.01 & 0.07 & 0.38\end{array}$

$\begin{array}{lllll}0.46 & 0.39 & 0.07 & 0.39 & -0.32\end{array}$

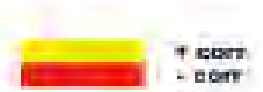

$-0.48$

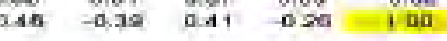


Foraminifers were divided into morphogroups (miliolids, rotaliids, agglutinates, and buliminids) and subsequently subdivided into percent larger-percent smaller fractions. The most abundant foraminifers belong to the miliolid morphogroups, of which $\sim 72$ percent of the samples were dominated by the percent-small fraction (fig. 4.2). Percent-small miliolids correlated positively with TOC- and percent $\mathrm{CO}_{3}$ and negatively with latitude, whereas larger forams had a perfect correlation with latitude (table 4.2).

The percent-small rotaliids were found to be persistent, in lower amounts, throughout the sampling sites and were dominated by the stress-tolerant taxa Elphidium and Rosalina. These correlated negatively with latitude (table 4.2). The percent-large rotaliids are dominated by symbiontbearing Asterigerina spp., with scarce Amphistegina spp., found to be relatively abundant at the $30-\mathrm{m}$ depth contour (app. 4.1). The percent agglutinates and buliminids were limited to Bigenerina-Textularida spp. and Polymorphina spp., respectively. Percent large/small rotaliids showed no correlation with physical parameters (table 4.2).

The FAI and $\mathrm{H}(\mathrm{S})$ indexes (table 4.1) show a positive correlation with D50, but the latter were negatively correlated with percent-larger miliolids and latitude (table 4.2). The Equitability Index (E'), degree of evenness or species distribution, showed positive correlation with percent-smaller miliolids.

Two-way cluster analysis showed three $\left(\mathrm{A}^{\prime}-\mathrm{C}^{\prime}\right)$ distinct assemblages (app. 4.2). Of these, assemblage $\mathrm{A}^{\prime}$ and $\mathrm{B}^{\prime}$ were composed of the most abundant species, whereas assemblage $\mathrm{C}^{\prime}$ consisted mainly of single-species occurrences. Assemblage A' consisted of Archaias angulatus -Laevipeneroplis carinatus -Quinqueloculina cf. candeiana -Asterigerina spp. -Q. spp. Assemblage B' was composed of Triloculina spp. -Q. agglutinans $-Q$. bicostata f. typica $-Q$. cf. bicarinata -Amphistegina gibbosa-Nodabaculariella spp. -T. cf. trigonula-Textularida spp. Foraminiferal assemblage A'-B' spatial distribution was commonly found at the 30-m depth contour, while assemblage $\mathrm{C}^{\prime}$ was on the 15-m contour (fig. 4.1).

A non-transformed Pearson cross-correlation matrix was performed on 15 variables (see Methods). Their correlation coefficients are shown on table 4.2. Interestingly, there was no correlation between percent large/small morphogroups and sediment characteristics except for TOC and percent $\mathrm{CO}_{3}$. On the other hand, by examining species level (such as Triloculina $c f$. trigonula), an overall negative correlation (0.50 to -0.84) with percent sand and a positive one $(+0.52$ to +0.86$)$ with percent mud seemed to favor the miliolids (including Quinqueloculina sp. and Triloculina sp.) (app. 4.3). Slight positive correlations $(>+0.50)$ occurred relatively evenly with certain rotaliids and miliolid species with D50.

\section{Discussions and Conclusions}

Sediment composition is primarily dominated by mollusk fragments followed by foraminifers. No direct relation is observed between latitude and foraminiferal distribution. It could be assumed that oceanographic conditions (for example, $\mathrm{pH}$ and salinity) are not controlling the distribution of foraminifers in the area.

Three main foraminiferal assemblages are present in the study area. Their distribution was speculated to be controlled mainly by freshwater influx from Tampa Bay and Charlotte Harbor, and normal marine conditions toward the Florida Keys. The actual distribution shows northwest-southeast bands apparently controlled by sediment composition and grain size.

Assemblage $A^{\prime}$ is found in proximity to the Tampa Bay mouth (fig. 4.1). Such proximity is puzzling since the most dominant taxa in this assemblage are symbiont-bearing larger miliolids (Archaias angulatus), smaller non-symbiont-bearing miliolids (Quinqueloculina spp.; Q. cf. candeiana), and larger symbiont rotaliids (Asterigerina spp.). These high-magnesium calcite forams are commonly found in mesohaline to hypersaline systems. A quartz-rich sediment zone off the mouth of Tampa Bay (Brooks and others, 2003) could serve as a buffer zone in maintaining this assemblage at the $30-\mathrm{m}$ contour depth. This assumption coincides with the fact that percent small miliolids correlate positively with the carbonate content even though such composition does not surpass 40 percent.

Assemblage B' is dominated by Triloculina and Quinqueloculina spp. The distribution is divided into two regions (northwest and southeast). The northwest and southeast regions are similarly dominated by non-symbiont miliolids (Q. cf. candeiana) and symbiont-bearing miliolids (A. angulatus, P. orbitoloides, and L. carinatus), respectively. As with the previous assemblage, this assemblage is controlled by sediment composition (carbonate) and grain size (D50). Brooks and others (2003) found that quartz content decreases and carbonate content increases on an offshore transect.

Assemblage $C^{\prime}$ is dominated by an increasing trend in smaller rotaliids (Elphidium and Rosalina spp.) coupled with a decreasing trend in larger miliolids and rotaliids. This could be due to the proximity of the assemblage to the coastline, which is highly influenced by sediment composition (quartz). Grain size displays no relation with this assemblage (table 4.2).

Considering how the assemblages are spatially distributed, there is no consistency in diversity indices (table 4.1) on a north-south trend. Diversity is relatively low, based on $\mathrm{H}(\mathrm{S})$ and FAI, although it increases toward the south due to the presence of single individuals. Interestingly, $\mathrm{H}(\mathrm{S})$ and FAI show a relatively better distribution along the 30-m contour depth, indicating water depth as a possible controlling factor. 
The equitability index shows a relative consistency throughout the samples, with a dominance of small miliolids (positive correlation), which are widespread throughout the studied area. Since several miliolid species have a direct relation with percent mud (app. 4.3), it is safe to assume that the decrease in grain size (D50) toward the south is one of the factors controlling the distribution. On the other hand, the latitudinal control of larger miliolids, as a morphogroup, contributes to the above statement.

In conclusion, this study shows the lack of spatial distribution of larger benthic foraminifers, especially the symbiont-bearing miliolids. Larger benthic foraminifers seemed to dominate close to the mouth of Tampa Bay but are partially displaced by the smaller benthic foraminifers (Quinqueloculina sp., Elphidium sp.) toward the south. In general, all foraminifers were sparse in nearshore areas but increased in abundance at the $30-\mathrm{m}$ contour depth. The actual counted specimens do not provide a good basis for statistical analysis in relation to physical parameters.

\section{References Cited}

Brooks, G.R., Doyle, L.J., Davis, R.A., DeWitt, N.T., and Suthard, B.C., 2003, Patterns and controls of surface sediment distribution: West-central Florida inner shelf: Marine Geology, v. 200, p. 307-324.

Hallock, P., 2005, Global change and modern coral reefs: New opportunities to understand shallow-water carbonate depositional processes: Sedimentary Geology, v. 175, p. 19-33.
Hammer, Ø., and Harper, D.A.T., 2006, Paleontological statistics: Oxford, UK, Blackwell Publishing, 351 p.

Hine, A.C., Halley, R.B., Locker, S.D., Jarrett, B.D., Jaap, W.C., Mallinson, D.J., Ciembronowicz, K.T., Ogden, N.B., Donahue, B.T., and Naar, D.F., 2008, Coral reefs, present and past, on the west Florida shelf and platform margin, in Reigl, B., and Dodge, R.E., eds., Coral reefs of the U.S.A.: Netherlands, Springer, p. 127-173.

Hine, A.C., and Locker, S.D., in press, Florida Gulf of Mexico Continental Shelf - Great contrasts and significant transitions, in Buster, N.A., and Holmes, C.W., eds., Gulf of Mexico, origin, waters, and biota: Volume 3, Geology: College Station, TX, Texas A\&M Press.

Magurran, A.E., 1988, Ecological diversity and its measurements: Princeton, NJ, Princeton University Press, $175 \mathrm{p}$.

Obrochta, S.P., Duncan, D.S., and Brooks, G.R., 2003, Hardbottom development and significance to the sedimentstarved west-central Florida inner continental shelf: Marine Geology, v. 200, p. 291-306.

Yanko, V., Arnold, A.J., and Parker, W.C., 1999, Effects of marine pollution on benthic foraminifera, in Sen Gupta, B.K., ed., Modern Foraminifera: Netherlands, Kluwer Academic Publishers, p. 217-235. 


\title{
Section 5. Irradiance Data from the West Florida Shelf
}

\author{
By Brad Gooch ${ }^{1}$
}

\section{Introduction}

Benthic algae are an important food source for many shallow marine organisms and are crucial to the efficiency of this ecosystem. A research cruise from the University of South Florida was conducted in April of 2008 to collect data on the amount of light and its specific wavelengths that extend through the water column of the west Florida shelf (fig. 1.2). This data set is crucial to understanding if light penetration is sufficient for benthic algal production. Moran and Miller (2007) have described what kinds of individual wavelengths can penetrate at certain depths in the coastal-ocean zones. The driving question behind this research is, at what latitudinal and depth zone combinations are benthic algal productions affected?

\section{Methods}

The cruise departed from the Tampa Bay area, running south along the west Florida shelf at approximately the $15-\mathrm{m}$ depth contour. Sediment grab samples, Spectrophotometric Elemental Analysis System (SEAS) and Multiparameter Inorganic Carbon Analyzer (MICA) (Wang and others, 2007) measurements, and conductivity, temperature, depth

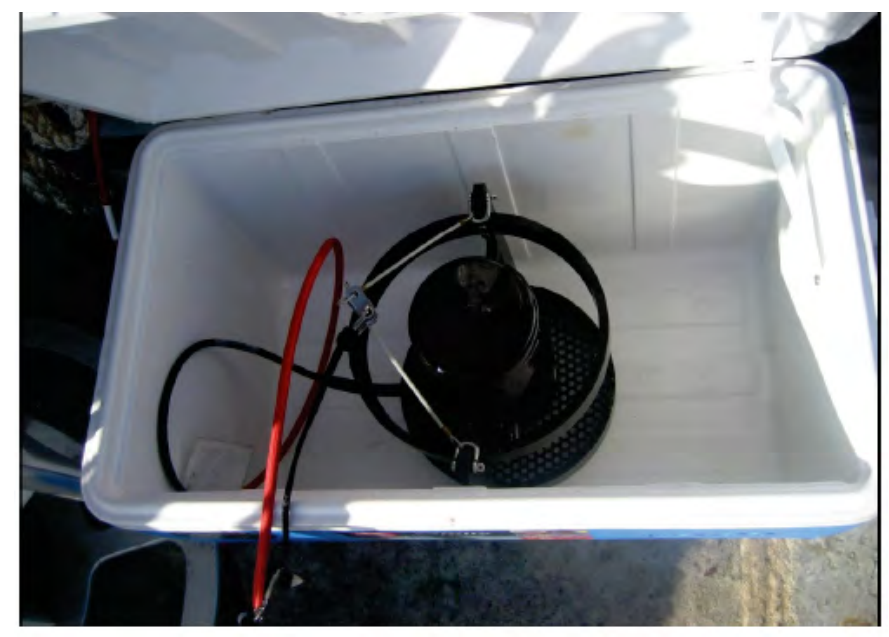

Figure 5.1 A Bus Interface Controller (BIC) series multichannel cosine irradiance spectroradiometer. When instrument was not deployed, the cap was placed over top, as seen here (Biospherical Instruments, Inc., 2003).
(CTD) profiles were taken every 3 hours. A Biospherical Instruments Bus Interface Controller (BIC) series multichannel cosine irradiance spectroradiometer, which collects sunlight from a flat-topped sensor that allows for 180 degrees of data collection (fig. 5.1), was also used. The BIC radiometer was deployed at all stops that were made between 10:00 a.m. and 2:00 p.m. (mid-day hours). Optical measurements of the water column were collected during daylight hours to estimate light penetration at depth. After 48 hours, the research vessel turned north, running at approximately the $30-\mathrm{m}$ depth contour, again sampling every 3 hours, until returning to the Tampa Bay area. The entire study area along with sites where light profiles were taken is displayed in figure 1.2. Data were also obtained using a Biospherical Instruments scalar irradiance spectroradiometer (fig. 5.2), which has a spherical sensor allowing for 360 degrees of data collection. Each device was lowered off the side of the research vessel and gradually dropped to a depth near the bottom (either 15 or $30 \mathrm{~m}$ ) and then recovered at the same gradual rate. Data were downloaded from the device into a computer and processed to adequately model the light profiles varying with depth.

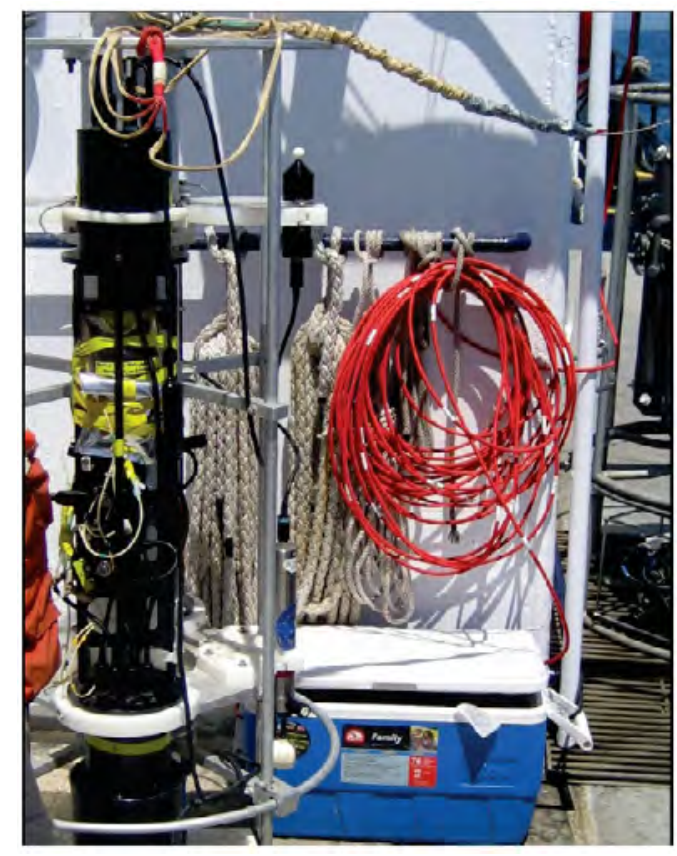

Figure 5.2 Scalar irradiance spectrometer attached to Spectrophotometric Elemental Analysis System (SEAS) instrument platform. 
Output from the detectors was converted from native units of the detector into the desired measurement. For optical sensors exposed to a flux, $\mathrm{E}_{1}(\lambda)$, a photodetector produces a sensor output voltage, $V$ :

$$
V=\int_{\lambda=0}^{\infty} E_{1}(\lambda) R(\lambda) d \lambda
$$

where $E 1(\lambda)$ is flux and $R(\lambda)$ is the spectral responsive function. The voltage was then converted into microEinsteins per square meter per second $\left(\mu \mathrm{Em}^{-2} \mathrm{~s}^{-1}\right)$. This value depends on the particular wavelength that is measured by the instrumentation. The SI unit for spectral irradiance is $\mathrm{Wm}^{-2} \mathrm{~nm}^{-1}$, and the SI unit for spectral radiance is $\mathrm{Wm}^{-2} \mathrm{~nm}^{-1} \mathrm{sr}^{-1}$ where $\mathrm{W}$ is watts, and $\mathrm{sr}$ is steradianWavelengths for the multichannel cosine irradiance spectroradiometer are in the 305, 330, 380 nanometer $(\mathrm{nm})$ range, and are Photosynthetically Available Radiation (PAR) wavelengths. The scalar irradiance spectroradiometer measures in PAR wavelengths. A PAR sensor is typically an irradiance sensor that is equally sensitive to light between 400 and $700 \mathrm{~nm}$ and insensitive to light outside this region (Biospherical Instruments Inc., 2003).

Once gathered, the data were processed and modeled. Known parameters from the data were in intensity readings that varied in time but did not have an attached depth profile. The data were modeled to obtain an intensity plot varying with depth. The fundamental equation needed to model the data is the logarithmic decay function:

$$
\mathrm{I}_{\mathrm{z}}=\mathrm{I}_{\mathrm{o}}^{\mathrm{e}(-\mathrm{kz}),}
$$

where $I_{z}$ is the intensity at some depth, usually maximum depth (known), $\mathrm{I}_{\mathrm{o}}$ is the intensity at surface (known), $\mathrm{k}$ is the extinction coefficient (unknown), and $\mathrm{z}$ is the depth (m) (partially known by the sinking rate of the CTD winch). This equation is also known as radiance.

The problem with this approach is that depth had to be calculated with the assumption of a constant rate of descent and ascent. Given this assumption, the extinction coefficient was calculated when known depth was at its maximum (table 5.1). From this, intensity values could be calculated for any depth. This procedure was used with each data set from each station. The fit of the modeled data to actual data was very good and can be seen in figure 5.3. Deck observations of direct sunlight during transit to stations were also taken.

\section{Results}

A total of five sites (stations $01,06,07,12$, and 13) have data that can be modeled and used in future studies (see fig. 1.2). Data from both instruments can be seen in figures 5.3-5.8 and appendix 5.1, but mainly the cosine irradiance spectroradiometer data were used for analysis. The data from each station were partitioned into four groups based on wavelength $(305,330,380 \mathrm{~nm}$, and PAR). All analyses of the water-column light profiles are from the modeled data at the 30-m depth using the cosine irradiance spectroradiometer.

The 305-nm wavelength (see fig. 5.4) at station 01 had the most loss of intensity at depth, with stations 06 and 07 being an order of magnitude higher than the other stations. Stations 12 and 13 had much more light at that wavelength penetrating at depth than the other stations by four to five orders of magnitude. The 330-nm wavelength (fig. 5.5) at stations 01 and 07 lost the most light at depth, with station 06 allowing slightly more light through the water column. Stations 12 and 13 allowed much more light through the water at depth by a few orders of magnitude. Station 07 lost the most intensity at this wavelength with stations 01 and 06 losing slightly less and being equal to each other. Stations 12 and 13 once again did not lose intensity at this wavelength, just like the other stations, being an order of magnitude higher. The wide-band PAR readings were lowest at stations 01,06 , and 07 , none of which had equal profiles. They were highest at the sites of stations 12 and 13 (fig. 5.7). The data from the scalar irradiance spectroradiometer were also plotted with depth (fig. 5.8). Although the units are measured at milliEinsteins per square meter per second $\left(\mathrm{Em}^{-2} \mathrm{~s}^{-1}\right)$ instead of at $\mu \mathrm{Em}^{-2} \mathrm{~s}^{-1}$, the comparison can still be made to the similarity of readings by each of the instruments. Most of the results of the PAR were inconclusive (see app. 5.1). The deck readings of UV and visible light showed that there was nothing erroneous in the data collection of the devices and allowed the instruments to be calibrated (app. 5.1).

Table 5.1 Cruise data used to derive extinction coefficient (k) and intensity (Iz).

\begin{tabular}{lcccccc}
\hline Wavelength & $\begin{array}{c}\text { Intensity at } \\
\left(\mathbf{I}_{\mathbf{z}}\right) \text { depth }\end{array}$ & $\begin{array}{c}\text { Intensity at } \\
(\mathbf{l}) \text { surface }\end{array}$ & Iz/lo & In Iz/lo & $\begin{array}{c}\text { Depth in } \\
\text { meters }(\mathbf{z})\end{array}$ & $\begin{array}{c}\text { Extinction } \\
\text { coefficient } \\
(\mathbf{k})\end{array}$ \\
\hline PAR & 338.0521 & 1705.539 & 0.198208 & -1.61844 & 12 & 0.13487 \\
305 & $1.46 \mathrm{E}-03$ & $2 / 166473$ & 0.000673 & -7.30375 & 12 & 0.608646 \\
330 & 0.336671 & 31.37844 & 0.010729 & -4.53477 & 12 & 0.377897 \\
380 & 7.232895 & 54.86613 & 0.131828 & -2.02626 & 12 & 0.168855 \\
\hline
\end{tabular}




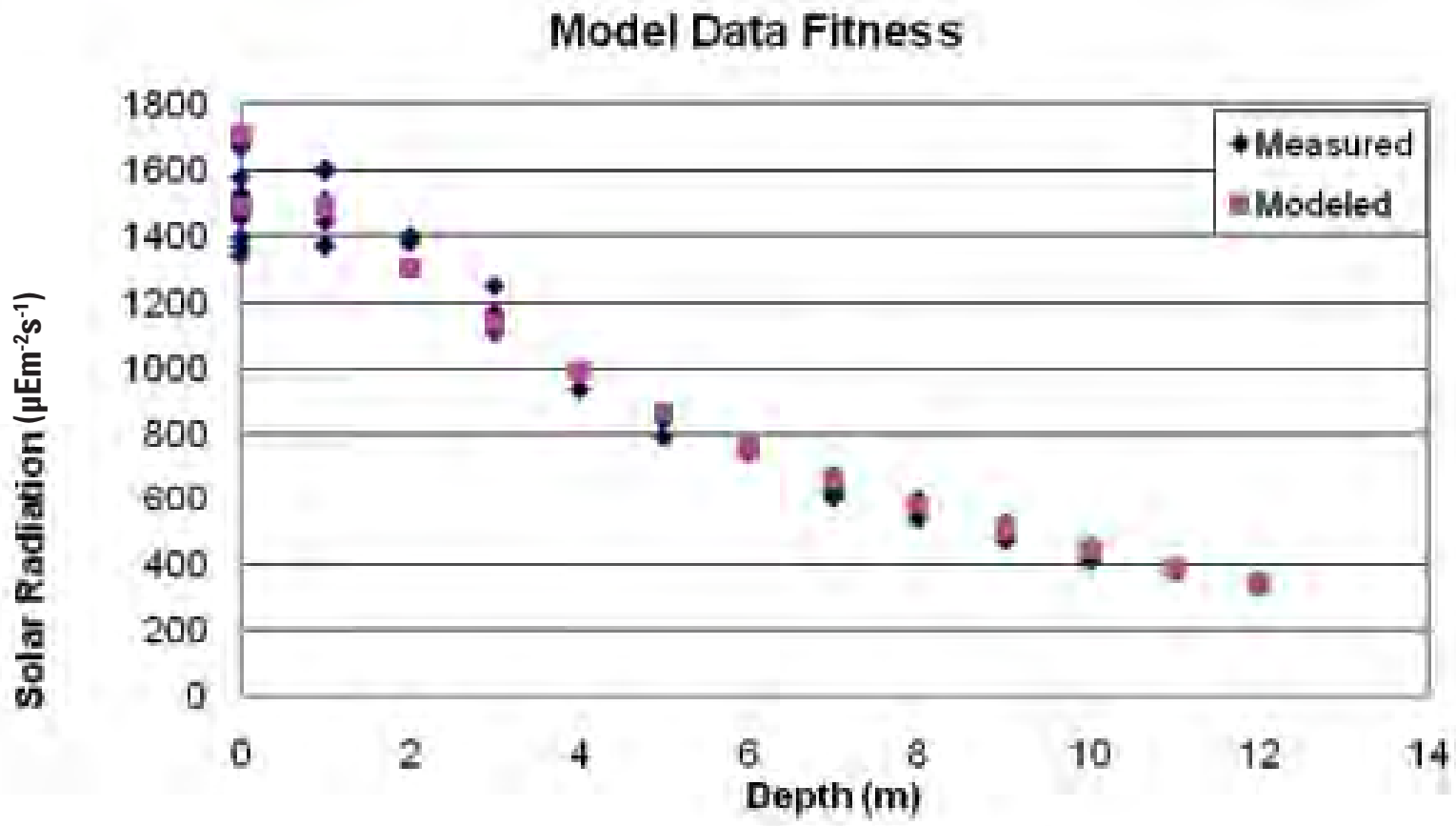

Figure 5.3 Measured versus modeled irradiance values, stations 1, 6, 7, 12, and 13. Units in $\mu \mathrm{Em}^{-2} \mathrm{~s}^{-1}$.

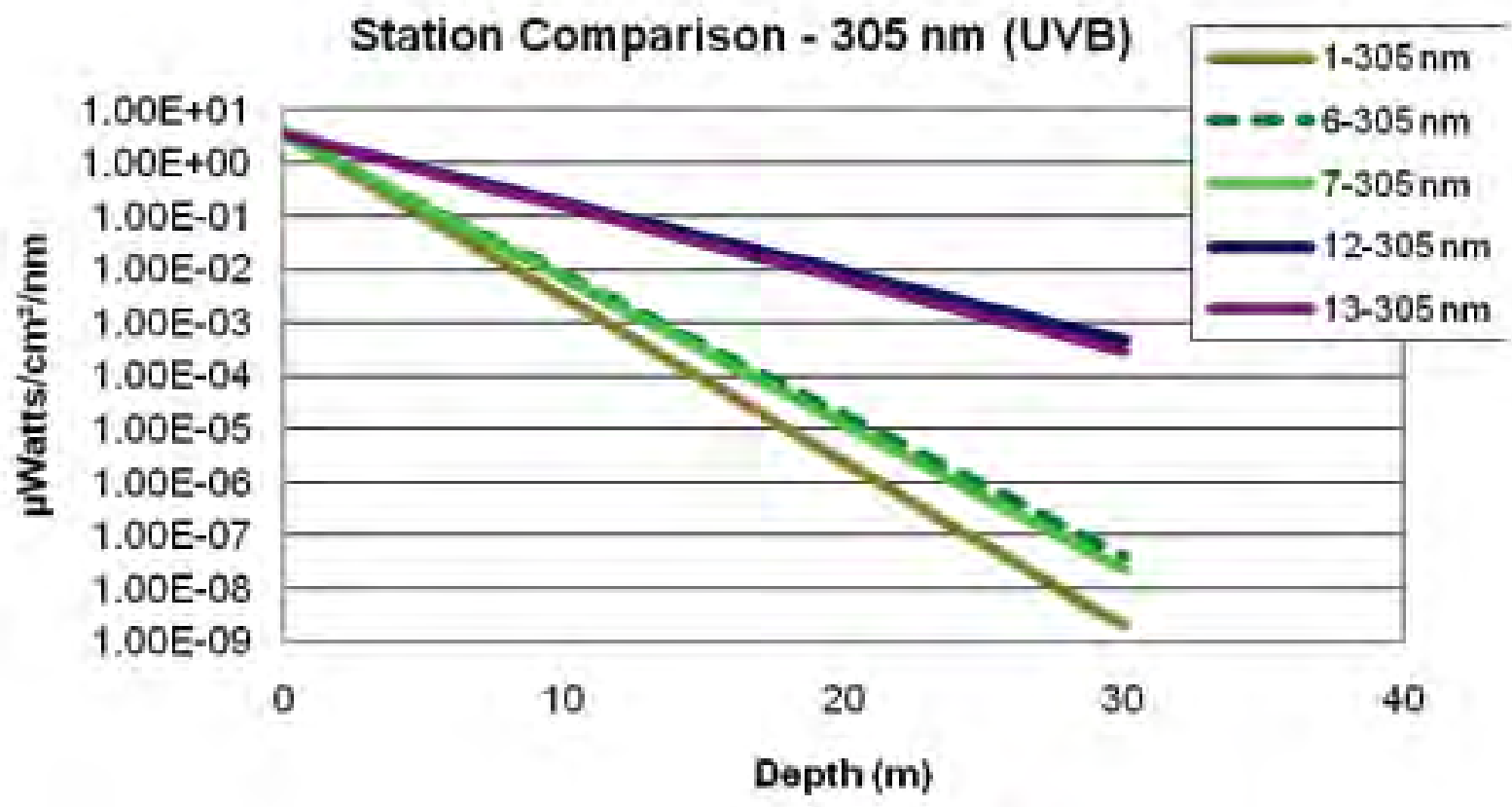

Figure 5.4 Modeled data at sites 1, 6, 7, 12, and 13 at the 305-nm wavelength. UVB $=$ Ultraviolet $B$. 


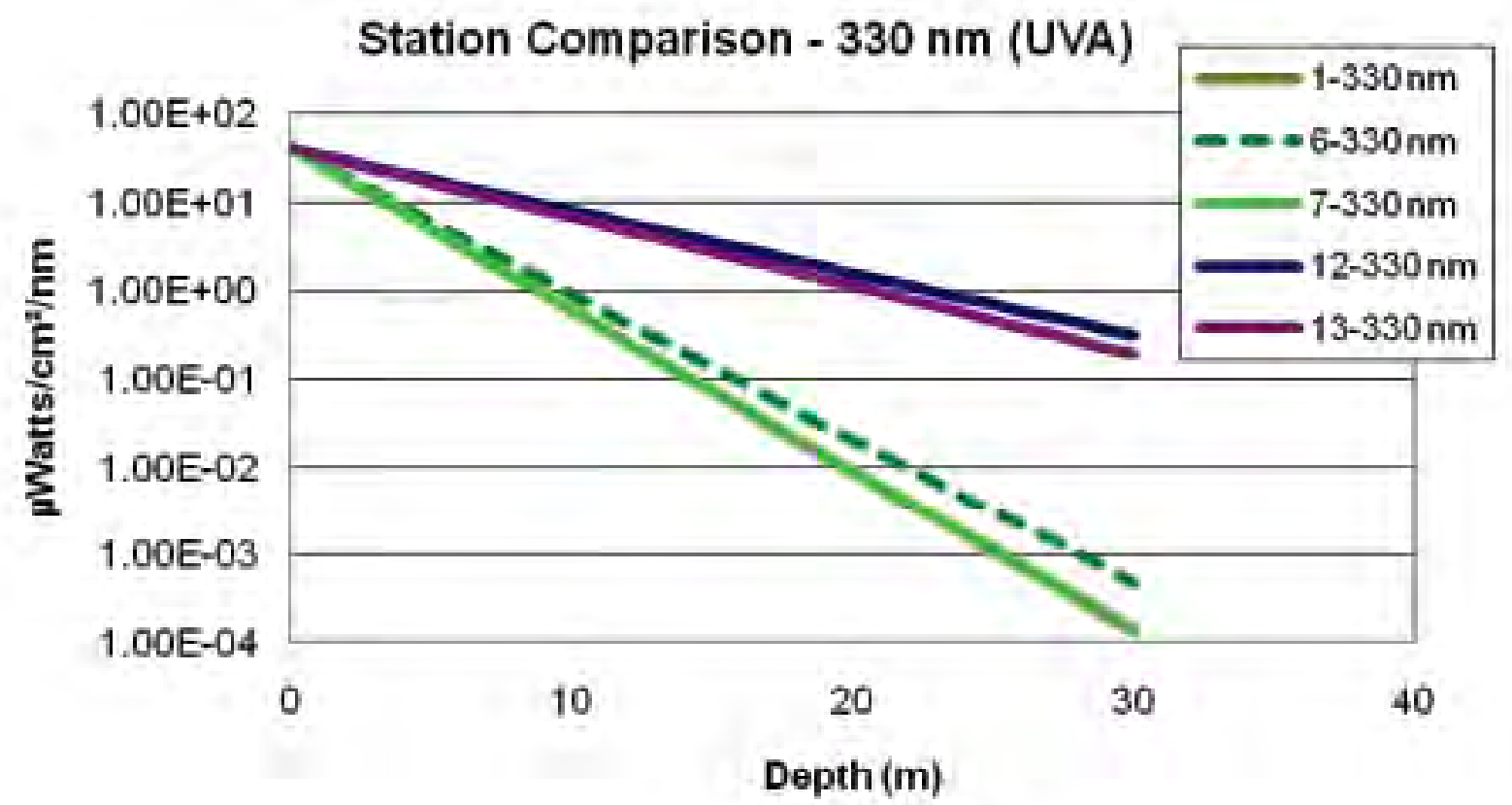

Figure 5.5 Modeled data at sites 1, 6, 7, 12, and 13 at the 330-nm wavelength. UVA = Ultraviolet A.

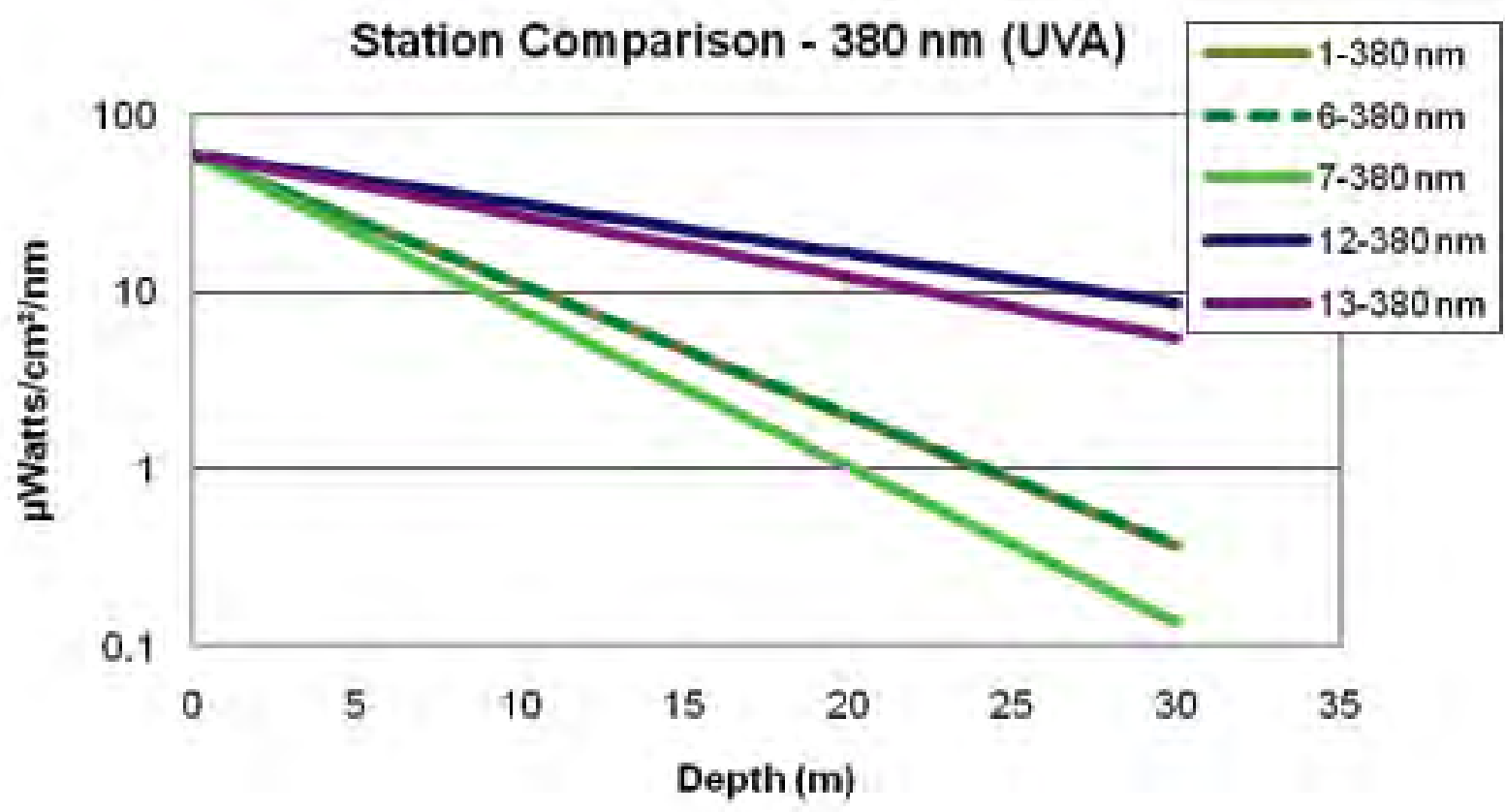

Figure 5.6 Modeled data at sites 1, 6, 7, 12, and 13 at the 380-nm wavelength. UVA = Ultraviolet 


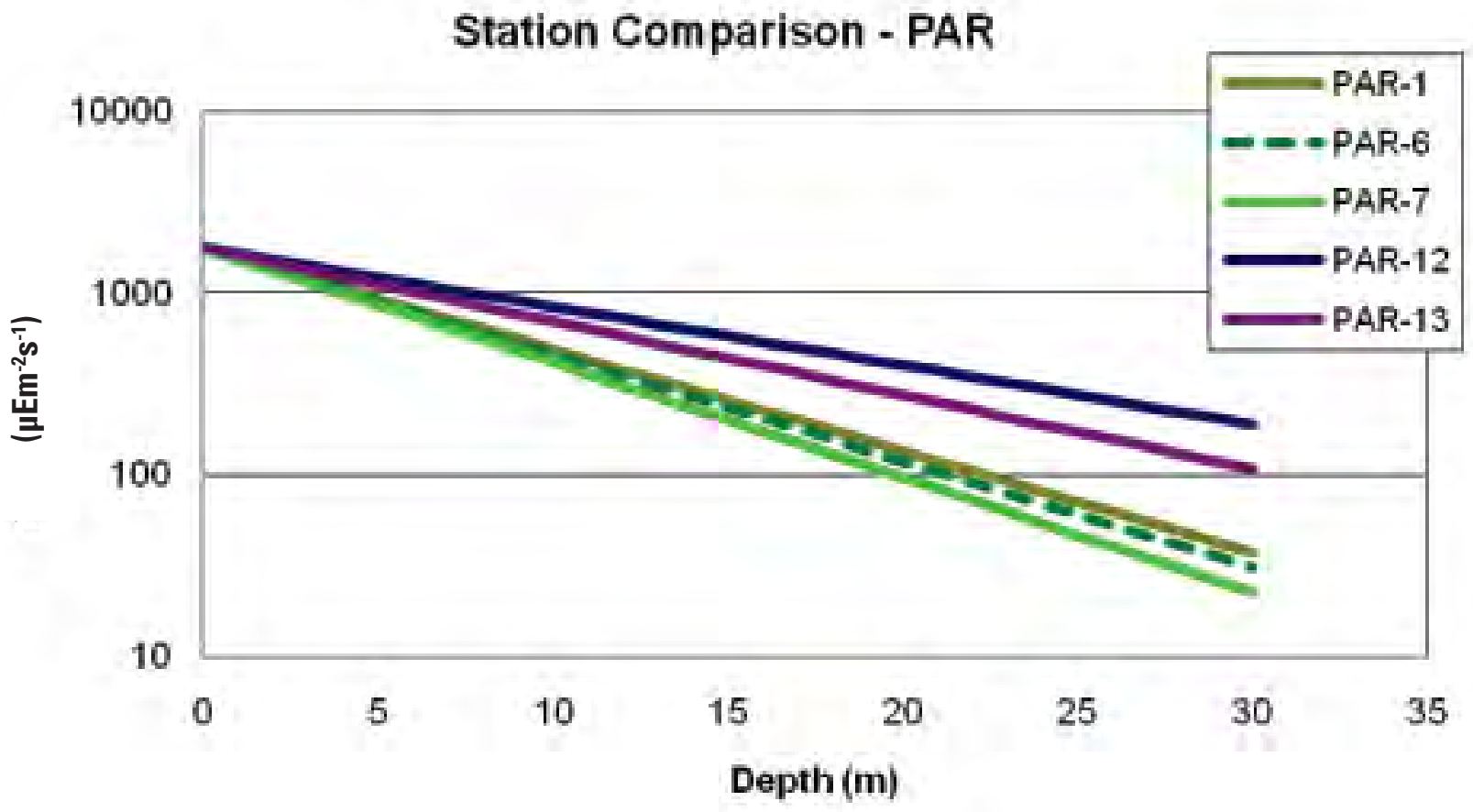

Figure 5.7 Modeled data at sites 1, 6, 7, 12, and 13 at the Photosynthetically Available Radiation (PAR) band.

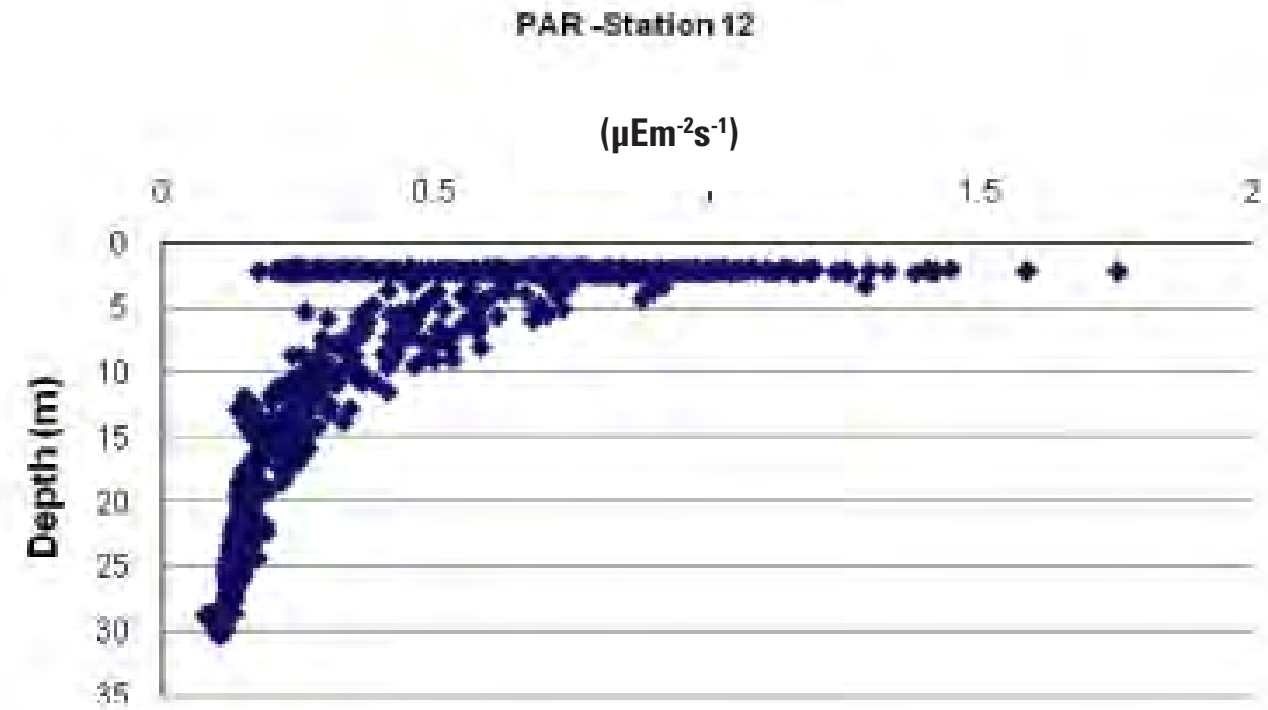

Figure 5.8 Photosynthetically Available Radiation (PAR) data modeled from the scalar irradiance spectroradiometer. 


\section{Discussion and Conclusions}

Data were not collected from all stations (see fig. 1.2). Five data points were able to be interpreted for this study. The results showed that the penetration of various wavelengths of light was mostly a function of the proximity to the shoreline. This result does not support any kind of a hypothesis on a transition between the latitudinal changes on the west Florida shelf at those depth contours. Wavelength penetration at stations 12 and 13 were fairly constant to each other and at each station lost less of each wavelength than was lost at the other stations. This was largely due to the fact that those stations were the only $30-\mathrm{m}$ depth sites in the study. The deeper water off the Florida coastline is known to be much less turbid and even seems to be less green and more blue. The color, in general, is a function of suspended particulates. The results of the nearshore stations were that each allowed less light to penetrate at each wavelength at depth than those in deeper water. Also, each of the sites had profiles that varied with respect to each other. This variation could be linked to absorptions of different wavelengths by various biologic entities, a factor that is beyond the scope of this research.

The error sources of the data could also be a factor in the subtle differences of the data but not of the large trends. The problems associated with the PAR data of the scalar irradiance spectroradiometer stem from the fact that the sensor was attached to a platform containing many other data collection instruments and was, at times in the ship's shadow. Also, the timing of the descent and ascent of that instrument was erratic and difficult to model. General discrepancies of the data could come from error in modeling calculations but are most likely from interference of the ship's shadow on the devices.

\section{References Cited}

Biospherical Instruments Inc., 2003, BIC Series User's Manual: San Diego, CA, Biospherical Instruments Inc., accessed April 12, 2010, at http://www.biospherical.com.

Moran, M.A., and Miller, W.L., 2007, Resourceful heterotrophs make the most of light in the coastal ocean: Nature Reviews Microbiology, v. 5, p. 792-800.

Wang, Z., Liu, X., Byrne, R.H., Wanninkhof, R., Bernstein, R.E., Kaltenbacher, E.A., and Patten, J., 2007, Simultaneous spectrophotometric flow-through measurements of $\mathrm{pH}$, carbon dioxide fugacity, and total inorganic carbon in seawater: Analytica Chimica Acta, v. 596, p. 23-36. 


\section{Section 6. References (All papers)}

American Society for Testing and Materials, 1989, "Standard Test Method for Particle Size Analysis of Soils, Designation D 422-63," Annual Book of ASTM Standards, Philadelphia.

Biospherical Instruments Inc., 2003, BIC Series User's Manual: San Diego, CA, Biospherical Instruments Inc., accessed at http://www.biospherical.com.

Boggs, S., Jr., 1987, Sedimentary textures, in, eds., Principles of Sedimentology and Stratigraphy: Englewood Cliffs, NJ, Prentice-Hall, p. 64-71.

Brooks, G.R., Doyle, L.J., Davis, R.A., DeWitt, N.T., and Suthard, B.C., 2003, Patterns and controls of surface sediment distribution: West-central Florida inner shelf: Marine Geology, v. 200, p. 307-324.

Brooks, G.R., and Holmes, C.W., in press, West Florida Continental Shelf, in Buster, N.A., and Holmes, C.W., eds., Gulf of Mexico, origin, waters, and biota: Volume 3, Geology: College Station, TX, Texas A\&M Press.

Carver, R.E., ed., 1971, Procedures in Sedimentary Petrology: New York, NY, Wiley, 653 p.

Davis, R.A., Jr., 1989, Morphodynamics of the west-central Florida barrier system: The delicate balance between waveand tide-domination, in, ed., Coastal Lowlands, Geology and Geotechnology: Dordrecht, Kluwer, p. 225-235.

Dean, W.E., Jr., 1974, Determination of carbonate and organic matter in calcareous sediments and sedimentary rocks by loss on ignition: Comparison with other methods: Journal of Sedimentary Petrology, v. 44, no. 1, p. 242-248.

Enos, P., 1977, Holocene sediment accumulations of the South Florida shelf margin, in Enos, P., and Perkins, R.D., eds., Quaternary Sedimentation in South Florida; Geological Society of America Memoir147: Boulder, CO, p. 1-130.

Folk, R.L., 1965, Some aspects of recrystallization in ancient limestones, in Pray, L.C., and Murray, R.C., eds., Dolomitization and Limestone Diagenesis; SEPM Special Publication 13: Tulsa, OK, Society of Economic Paleontologists and Mineralogists, p. 14-48.

Folk, R.L., 1974, Petrology of Sedimentary Rocks: Austin, TX, Hemphill, 182 p.
Force, L.M., 1969, Calcium carbonate size distribution on the west Florida shelf and experimental studies on the microarchitectural control of skeletal breakdown: Journal of Sedimentary Petrology, v. 39, no. 3, p. 902-934.

Hallock, P., 2005, Global change and modern coral reefs: New opportunities to understand shallow-water carbonate depositional processes: Sedimentary Geology, v. 175, p. 19-33.

Hallock-Muller, P., 2008, West Florida shelf: A natural laboratory for the study of ocean acidification: Florida Institute of Oceanography Shiptime Proposal, University of South Florida, 5 p.

Hammer, Ø., and Harper, D.A.T., 2006, Paleontological statistics: Oxford, UK, Blackwell Publishing, 351p.

Heiri, O., Lotter, A.F., and Lemcke, G., 2001, Loss on ignition as a method for estimating organic and carbonate content in sediments: Reproducibility and comparability of results: Journal of Paleolimnology, v. 25, p. 101-110.

Hine, A.C., Brooks, G.R., Davis, R.A., Duncan, D.S., Locker, S.D., Twichell, D.C., and Gelfenbaum, G., 2003, The westcentral Florida inner shelf and coastal system: A geologic conceptual overview and introduction to the special issue: Marine Geology, v. 200, no. 1-4, p. 1-17.

Hine, A.C., Halley, R.B., Locker, S.D., Jarrett, B.D., Jaap, W.C., Mallinson, D.J., Ciembronowicz, K.T., Ogden, N.B., Donahue, B.T., and Naar, D.F., 2008, Coral reefs, present and past, on the west Florida shelf and platform margin, in Reigl, B., and Dodge, R.E., eds., Coral reefs of the U.S.A.: Netherlands, Springer, p. 127-173.

Hine, A.C., and Locker, S.D., in press, Florida Gulf of Mexico Continental Shelf - Great contrasts and significant transitions, in Buster, N.A., and Holmes, C.W., eds., Gulf of Mexico, origin, waters, and biota: Volume 3, Geology: College Station, TX, Texas A\&M Press.

Intergovernmental Panel on Climate Change, 2007, Climate change 2007: The physical science basis: Contribution of Working Group I to the Fourth Assessment Report of the Intergovernmental Panel on Climate Change: Cambridge, Cambridge University Press, 996 p. 
Kleypas, J.A, Feely, R.A., Fabry, V.J., Langdon, C., Sabine, C.L., and Robbins, L.L., 2006, Impacts of ocean acidification on coral reefs and other marine calcifiers: A guide for future research: Report of a workshop sponsored by National Science Foundation, National Oceanic and Atmospheric Administration and the U.S. Geological Survey, $88 \mathrm{p}$.

Kolbert, E., 2006, The darkening sea: New Yorker, November 2006, p. 66-75.

Lees, A., and Buller, A.T., 1972, Modern temperate-water and warm-water shelf carbonate sediments contrasted: Marine Geology, v. 13, p. 67-73.

Magurran, A.E., 1988, Ecological diversity and its measurements: Princeton, NJ, Princeton University Press, 175 p.

Moran, M.A., and Miller, W.L., 2007, Resourceful heterotrophs make the most of light in the coastal ocean: Nature Reviews Microbiology, v. 5, p. 792-800.

Obrochta, S.P., Duncan, D.S., and Brooks, G.R., 2003, Hardbottom development and significance to the sedimentstarved west-central Florida inner continental shelf: Marine Geology, v. 200, p. 291-306.

Read, J.F., 1985, Carbonate platform facies models: American Association of Petroleum Geologists Bulletin, v. 66, no. 1, p. $860-878$.

Robbins, L.L., Hansen, Raabe, E., Knorr, P., and Browne, J., 2007, Cartographic Production for the Florida Shelf Habitat (FLaSH) Map Study: Generation of Surface Grids, Contours, and KMZ files: U.S. Geological Survey OpenFile Report 2007-1397, 11p.

Ruttiman, J., 2006, Oceanography: Sick seas: Nature, v. 442, p. $978-980$.
Seibel, B.A., and Fabry, V.J., 2003, Marine biotic response to elevated carbon dioxide: Advances in Applied Biodiversity Science, v. 4, p. 59-67.

Tanner, W.F., 1960, Florida coastal classification: EOS Transactions, Gulf Coast Association of Geological Societies, v. 19, p. 259-266.

Walsh, J.J., Jolliff, J.K., Darrow, B.P., Lenes, J.M., Milroy, S.P., Remsen, A., Dieterle, D.A., Carder, K.L., Chen, F.R., Vargo, G.A., Weisberg, R.H., Fanning, K.A., Muller-Karger, F.E., Shinn, E.A., Steidinger, K.A., Heil, C.A., Tomas, C.R., Prospero, J.S., Lee, T.N., Kirkpatrick, G.J., Whitledge, T.E., Stockwell, D.A., Villareal, T.A., Jochens, A.E., and Bontempi, P.S., 2006, Red tides in the Gulf of Mexico: Where, when, and why?: Journal of Geophysical Research, v. 111, no. C11003, doi:10.1029/2004JC002813.

Wang, Z., Liu, X., Byrne, R.H., Wanninkhof, R., Bernstein, R.E., Kaltenbacher, E.A., and Patten, J., 2007, Simultaneous spectrophotometric flow-through measurements of $\mathrm{pH}$, carbon dioxide fugacity, and total inorganic carbon in seawater: Analytica Chimica Acta, v. 596, p. 23-36.

Weisberg, R.H., 2002, West Florida shelf: Physical oceanography [presentation]: HyCODE P.I. Meeting, accessed May 8, 2009, at http://www.opl.ucsb.edu/hycode/ pubs/hycode02/weisberg.ppt.

Weisberg, R.H., 2004, A west Florida case study: Coastal ocean circulation influences on remotely sensed optical properties: Oceanography, v. 17, no. 2, p. 69-75.

Wright, L.D., 1995, Morphodynamics of inner continental shelves: Boca Raton, FL, CRC Press, 241 p.

Yanko, V., Arnold, A.J., and Parker, W.C., 1999, Effects of marine pollution on benthic foraminifera, in Sen Gupta, B.K., ed., Modern Foraminifera: Netherlands, Kluwer Academic Publishers, p. 217-235. 


\section{Appendixes}


Appendix 1.1. Cruise SC-04-08 grab sample site locations and water depths (in meters). $[\mathrm{m}, \mathrm{meters}]$

\begin{tabular}{|c|c|c|c|}
\hline Site ID & $\begin{array}{l}\text { North } \\
\text { Latitude }\end{array}$ & $\begin{array}{c}\text { West } \\
\text { Longitude }\end{array}$ & $\begin{array}{c}\text { Water Depth } \\
\text { (m) }\end{array}$ \\
\hline 01 & 2721.562 & 8251.980 & 14 \\
\hline 02 & 2709.259 & 8238.530 & 15 \\
\hline 03 & 2652.087 & 8230.184 & 17 \\
\hline 04 & 2631.561 & 82.20 .947 & 15 \\
\hline 05 & 2614.975 & 8209.639 & 15 \\
\hline 06 & 2551.327 & $81,57,310$ & 15 \\
\hline 07 & 25.27 .810 & 8153.530 & 15 \\
\hline 08 & 2505.143 & 8150.567 & 18 \\
\hline 09 & 2450.875 & 8167.697 & 17 \\
\hline 10 & 2510.893 & 8221.163 & 31 \\
\hline 11 & 2536.163 & 8226.497 & 30 \\
\hline 12 & 2603.419 & 8237.951 & 31 \\
\hline 13 & 2620.816 & 8247.915 & 31 \\
\hline 14 & 2634.104 & 8254.147 & 35 \\
\hline 15 & 2650.442 & 8301.064 & 36 \\
\hline 16 & 2714.192 & 8307,592 & 33 \\
\hline 17 & 2733.929 & 8321.387 & 34 \\
\hline 18 & 2747.090 & 8310.060 & 22 \\
\hline
\end{tabular}




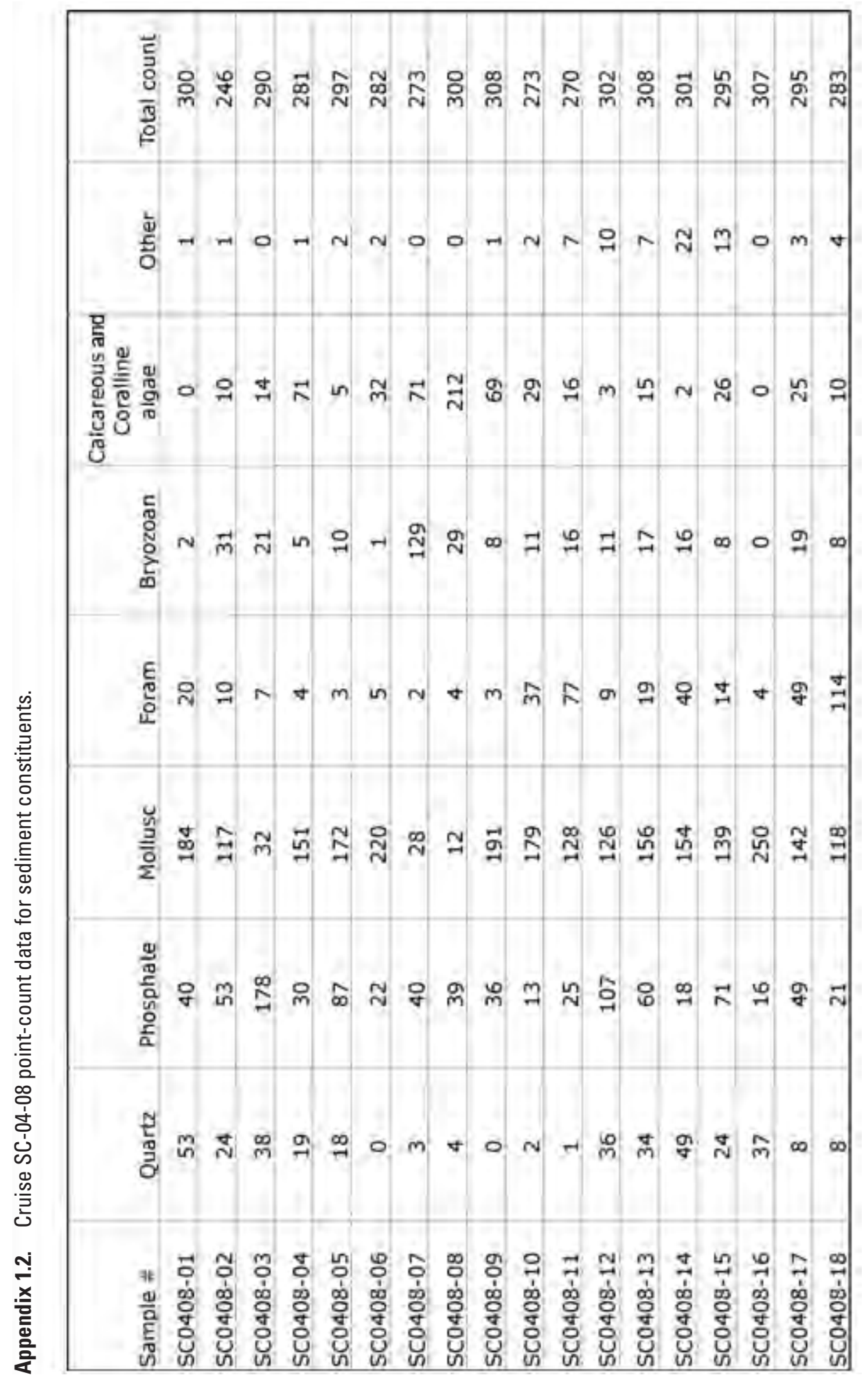


Appendix 1.3. Microscope photographs for all samples at whole phi intervals with associated point-count data and grain-size weight percent (see Beck, this volume).

[Note, 2- to 3- and 3- to 4- $\phi$ photographs taken under increased magnification. On photographs that are labeled, $\mathrm{M}=$ mollusc; $\mathrm{F}=\mathrm{foram} ; \mathrm{Q}=\mathrm{quartz} ; \mathrm{B}=$ bryozoan; $\mathrm{P}=$ phosphate grain; $\mathrm{C}=$ calcareous/coral algae; $\mathrm{T}=$ other $]$
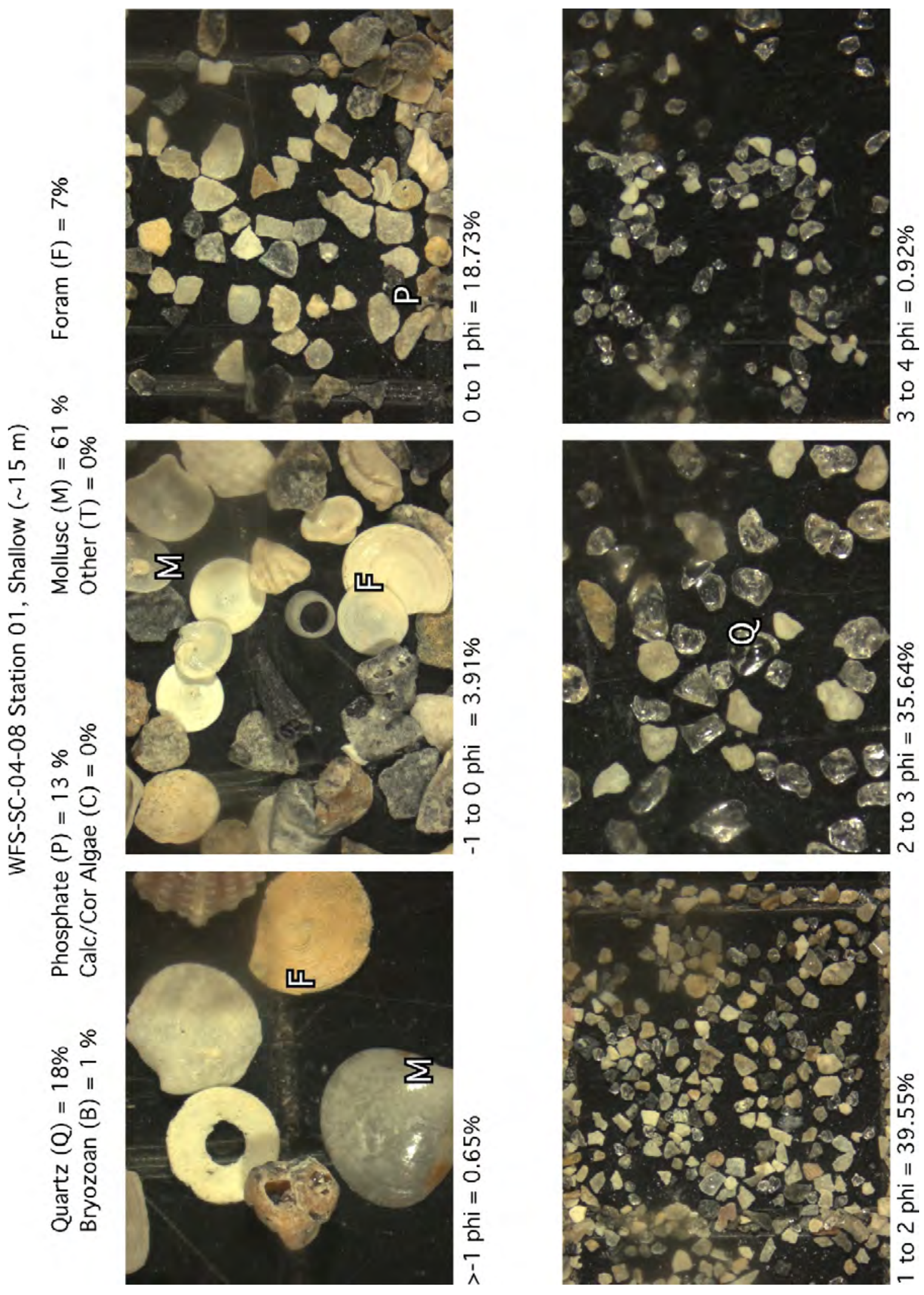


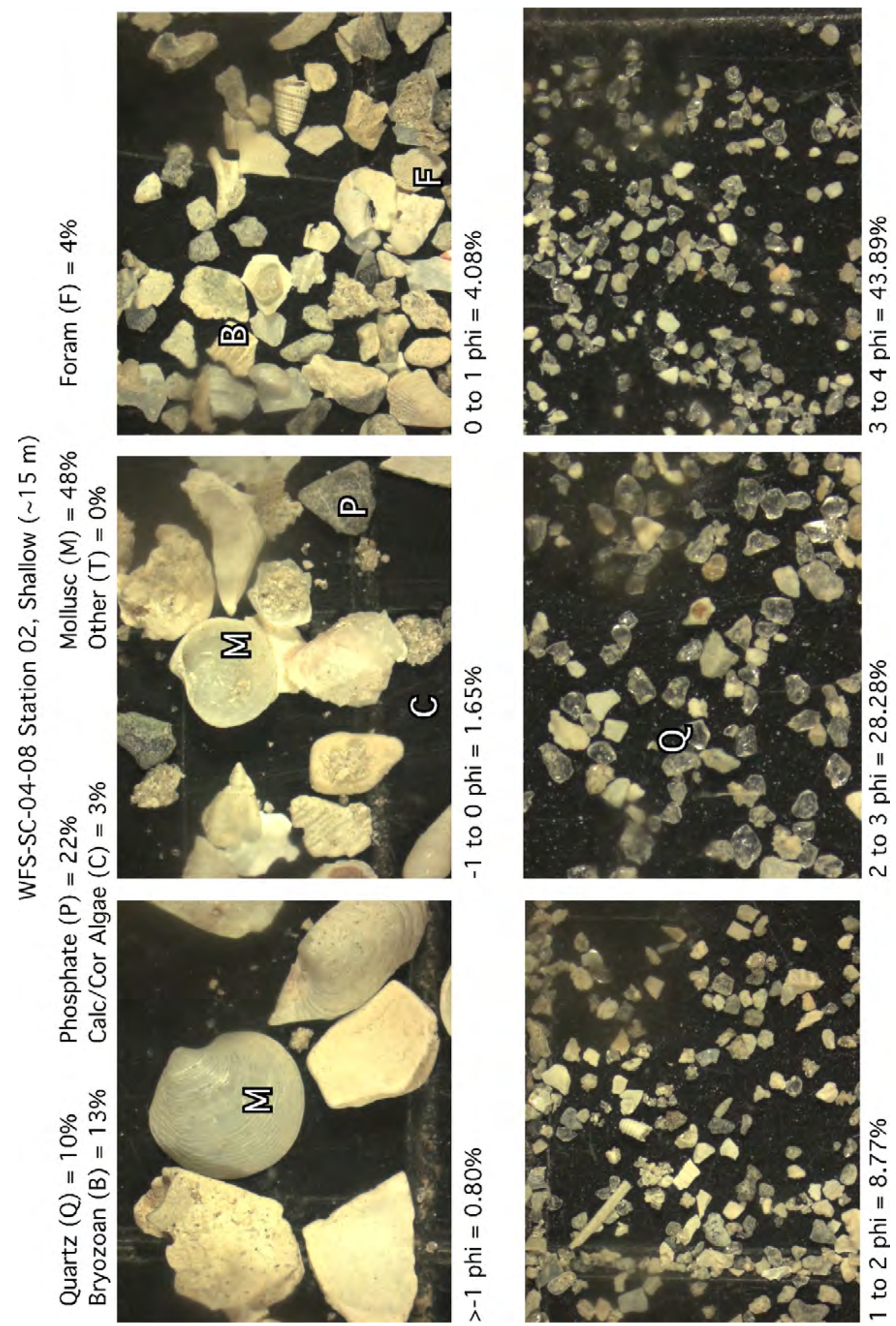



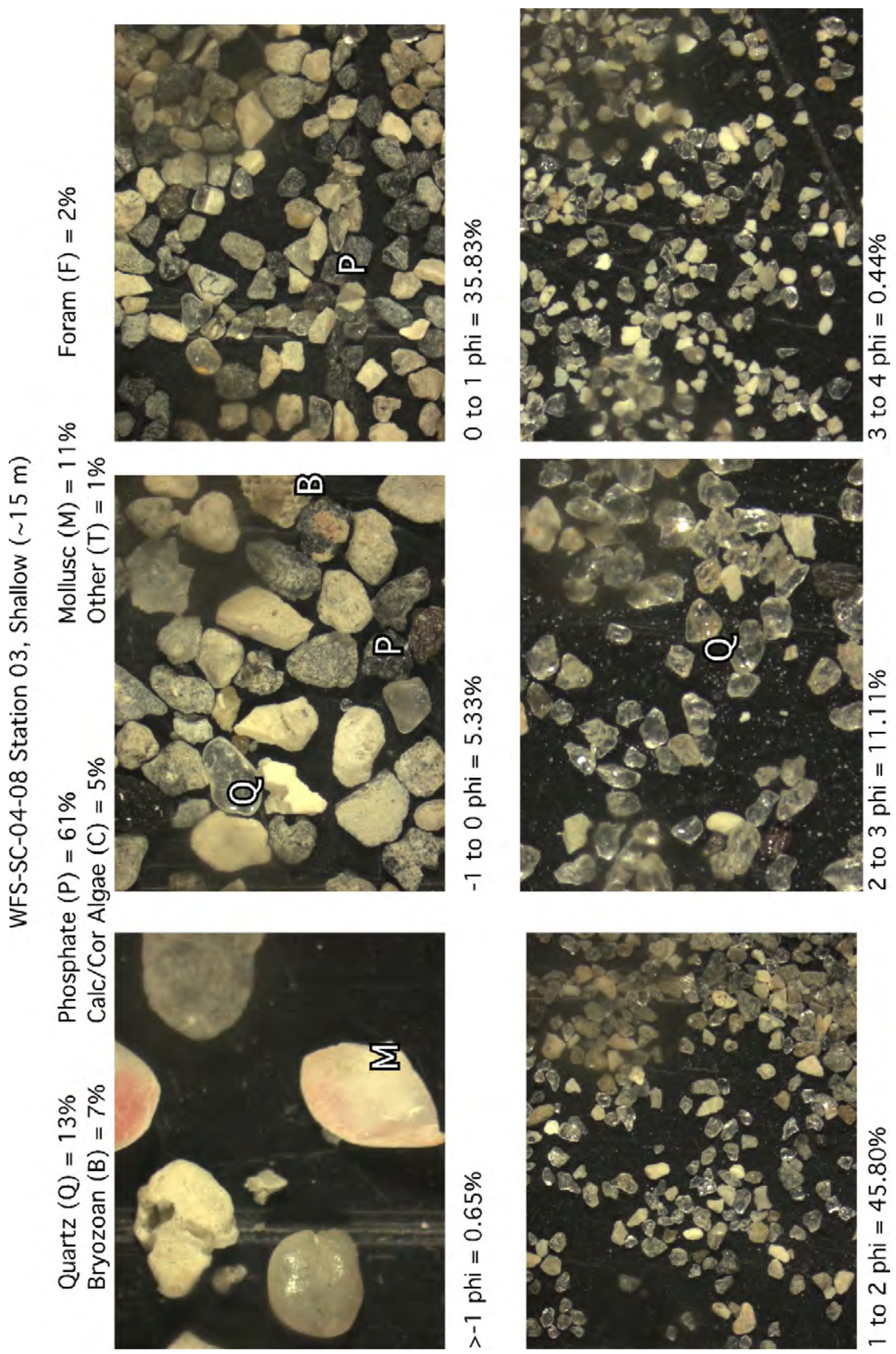

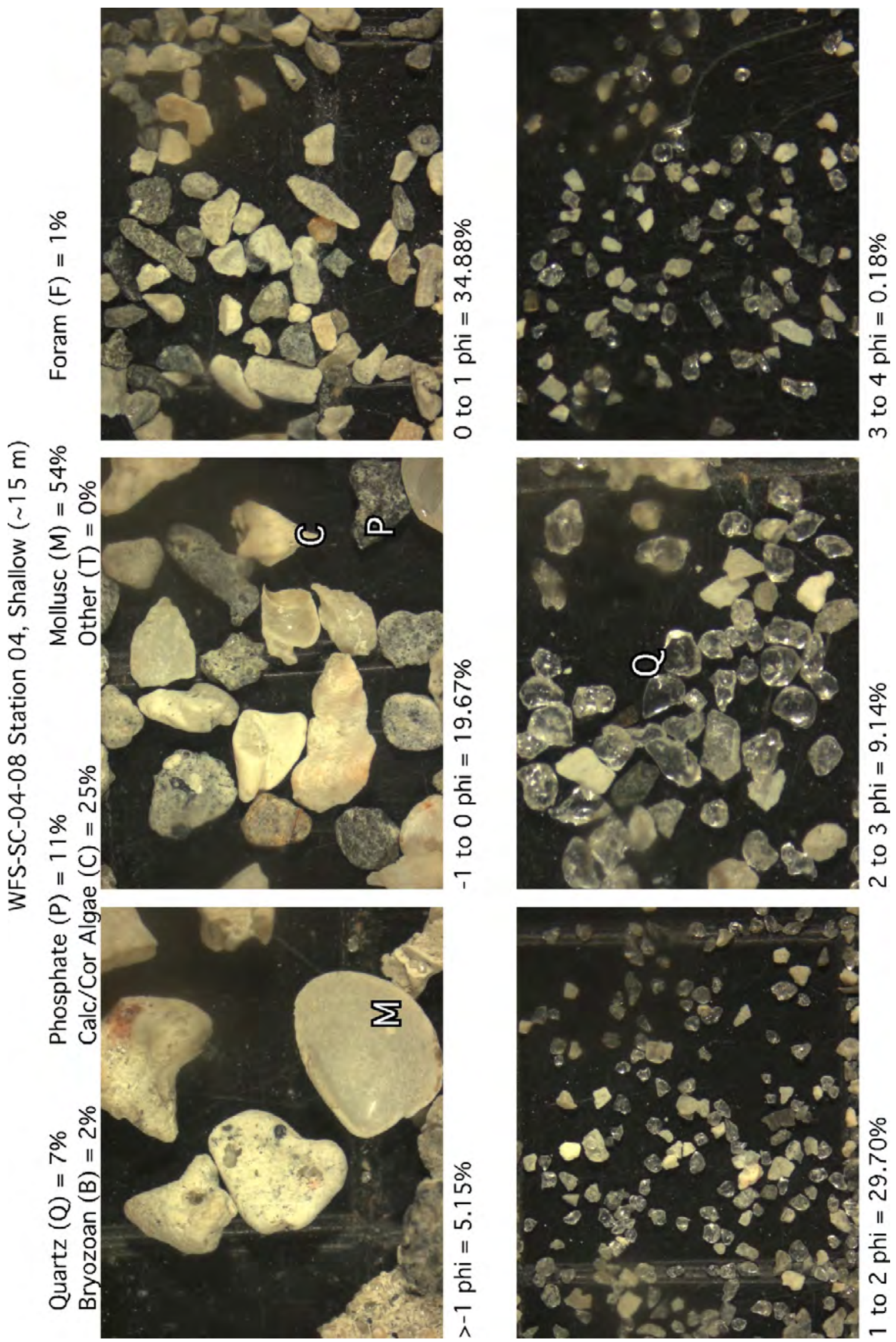


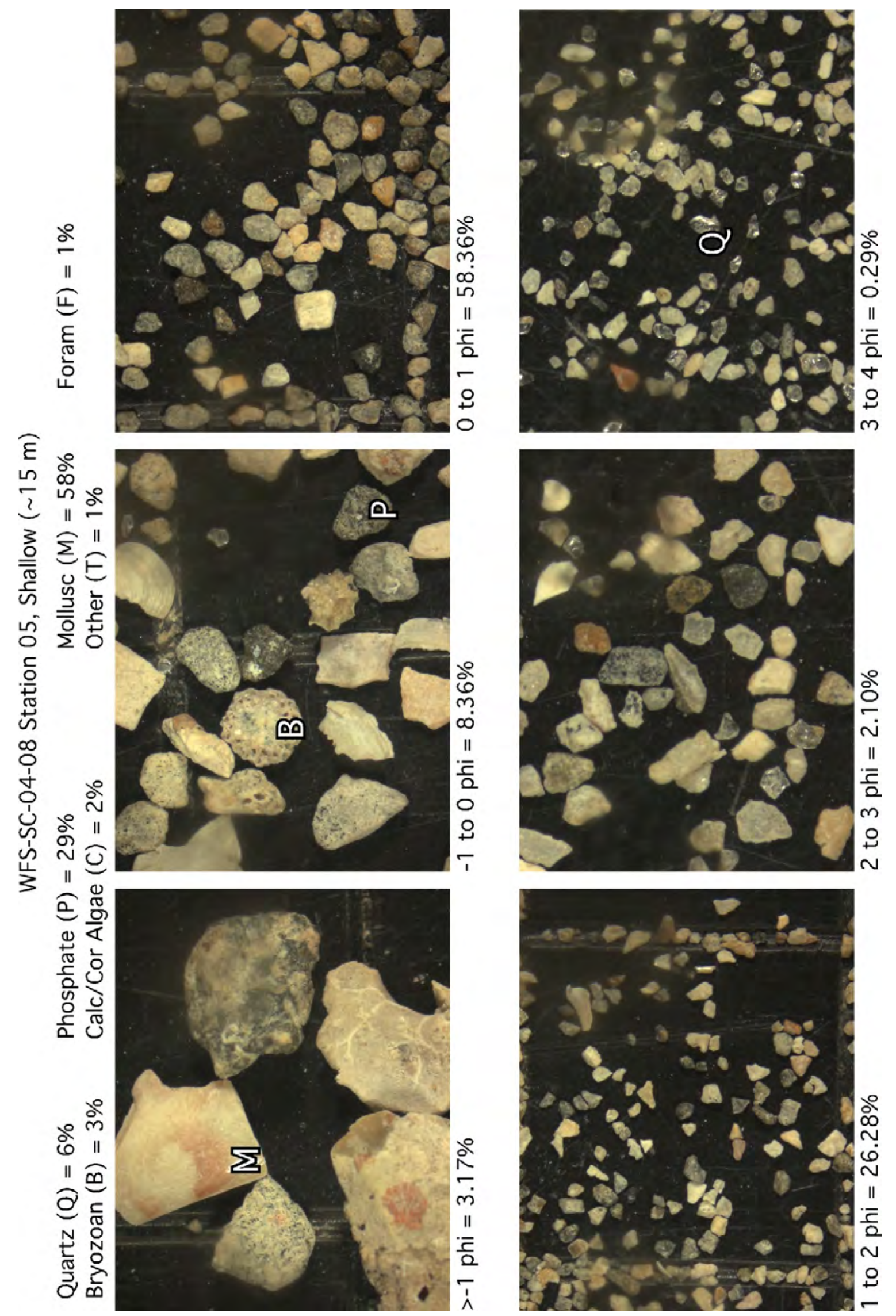



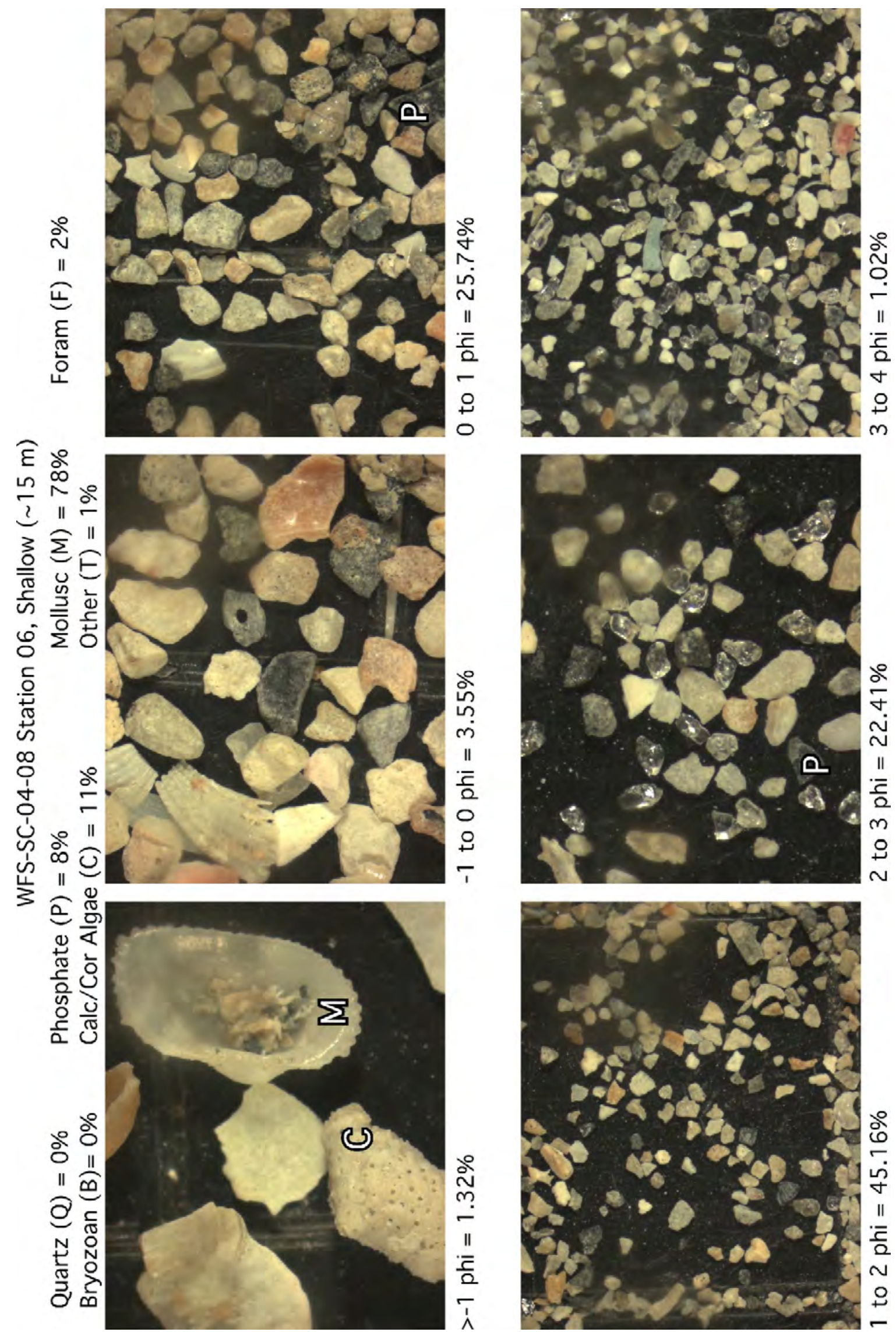

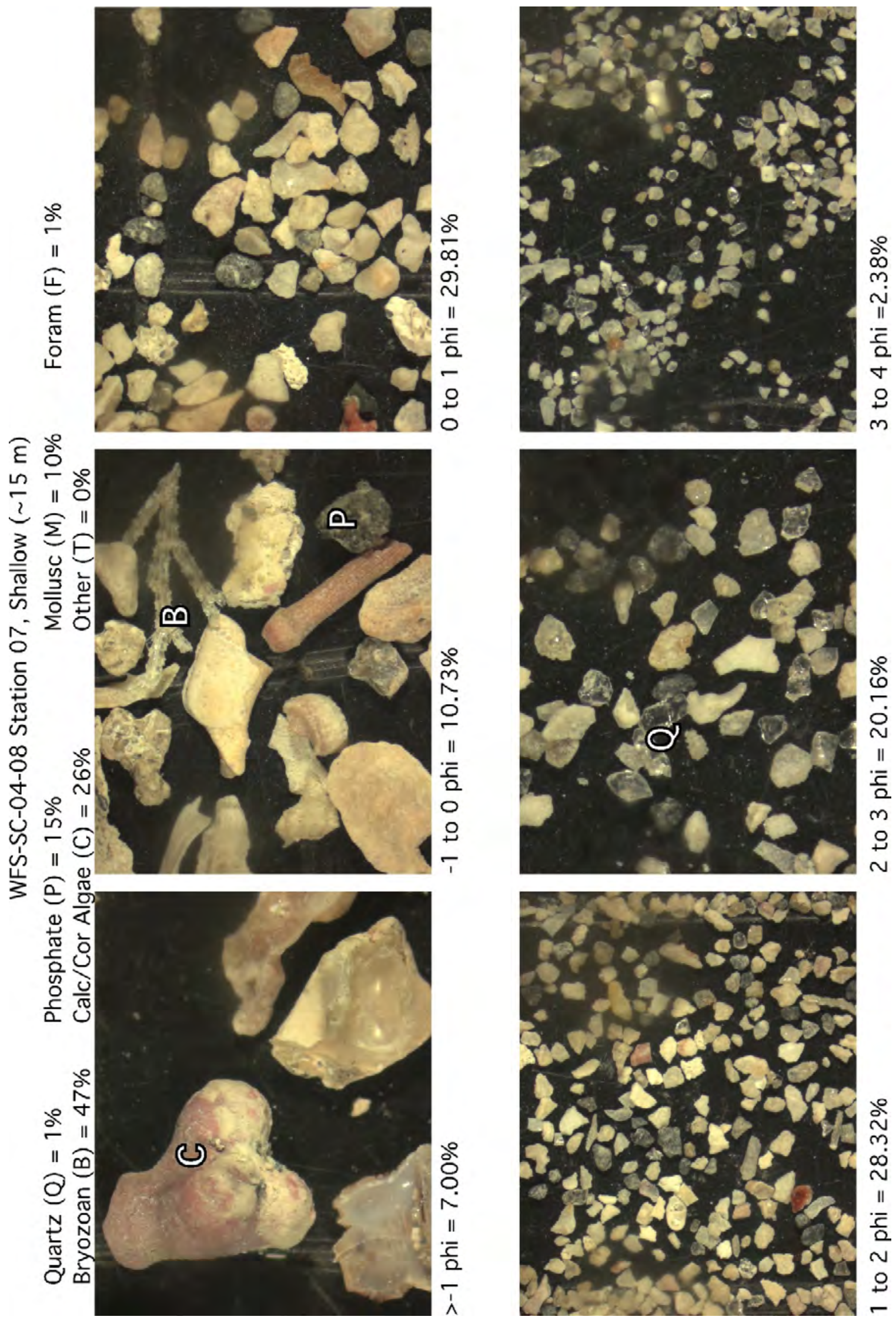

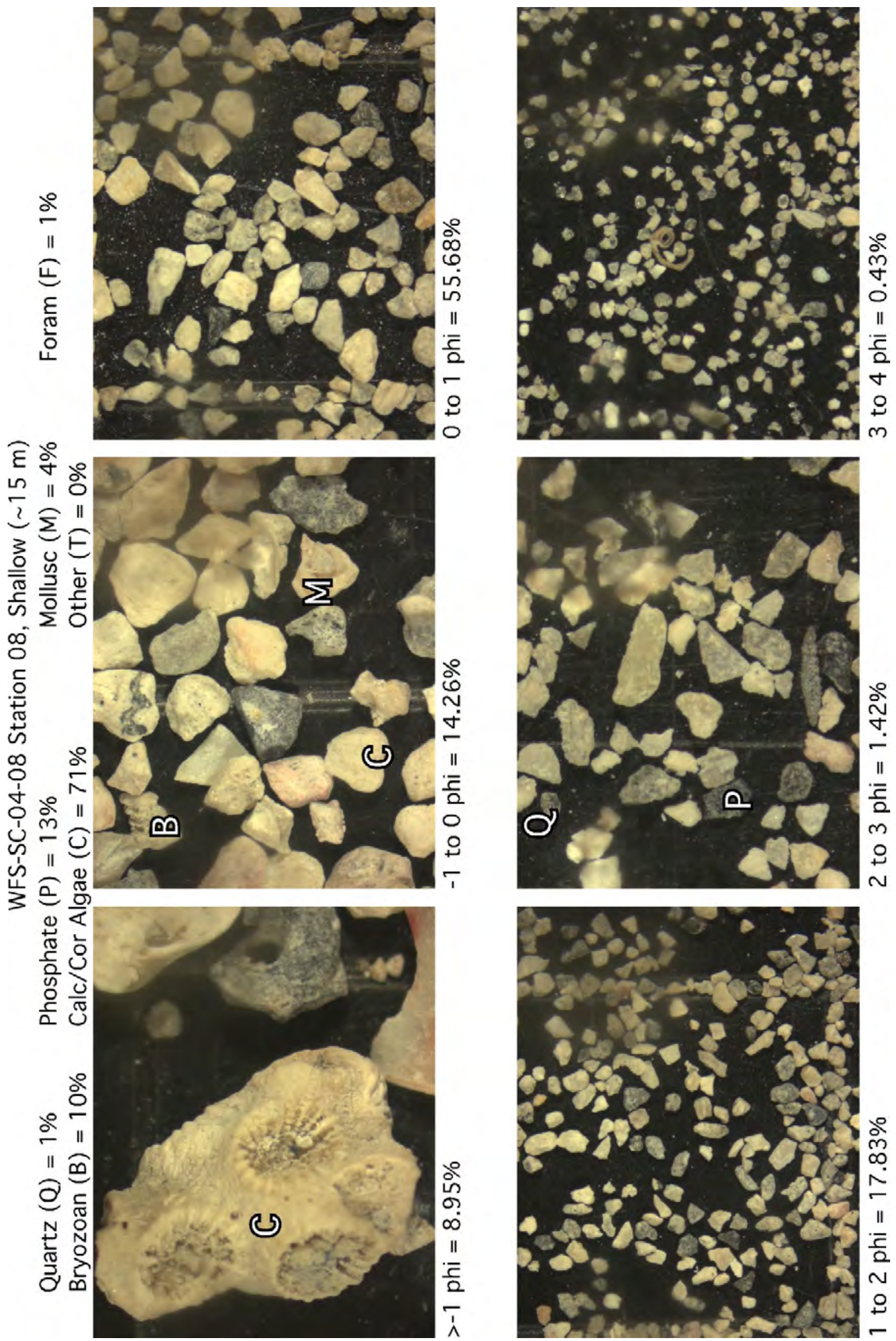

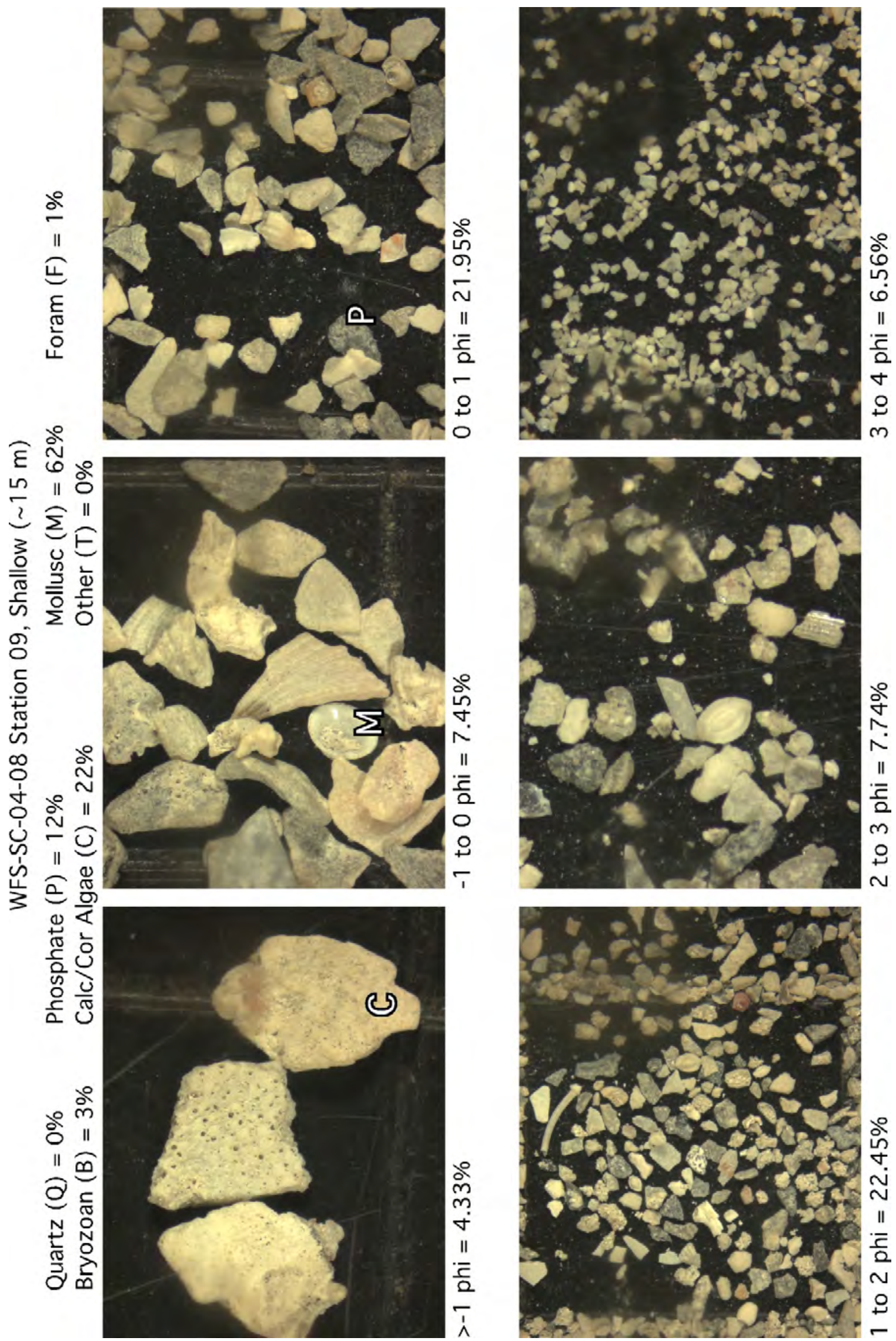

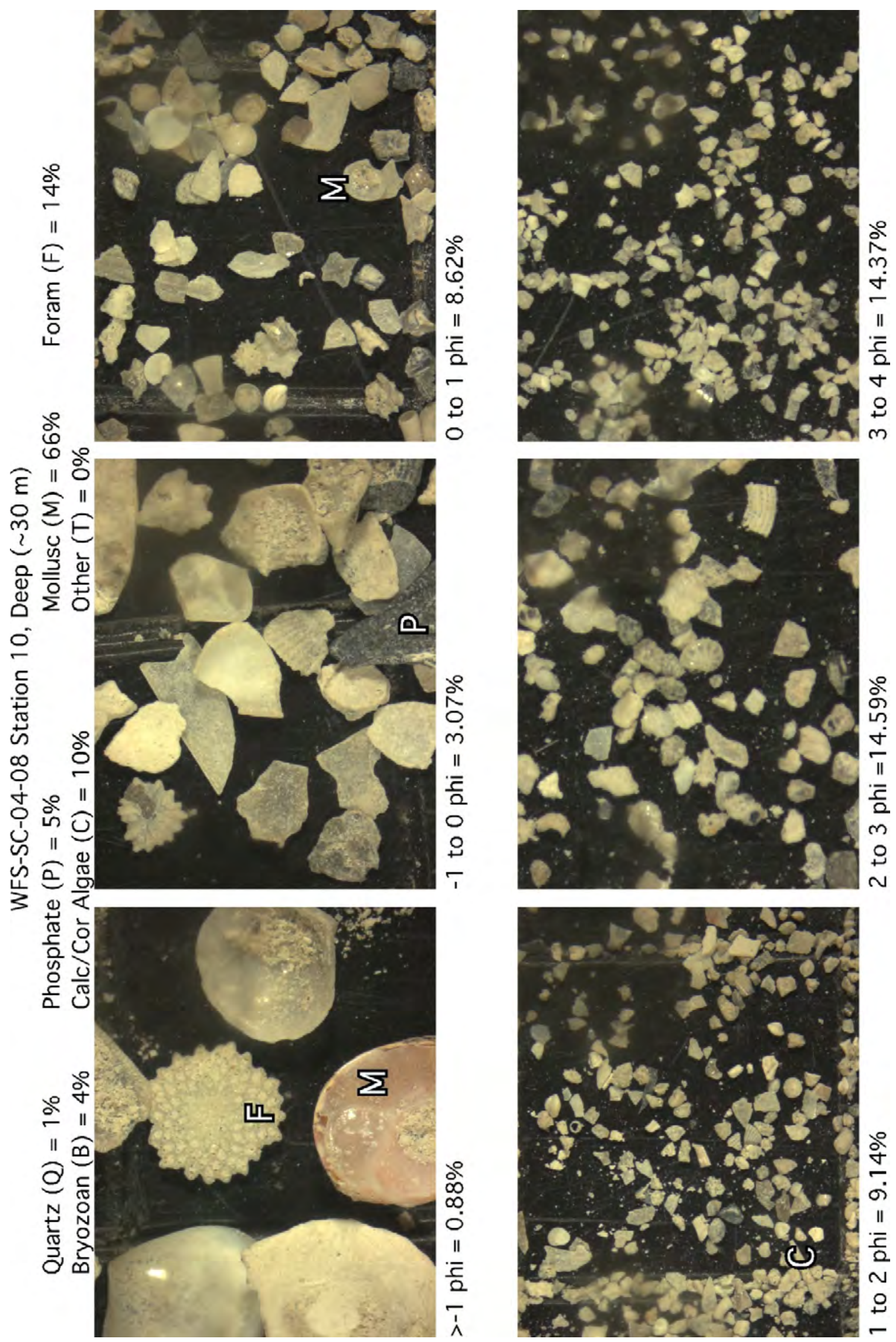

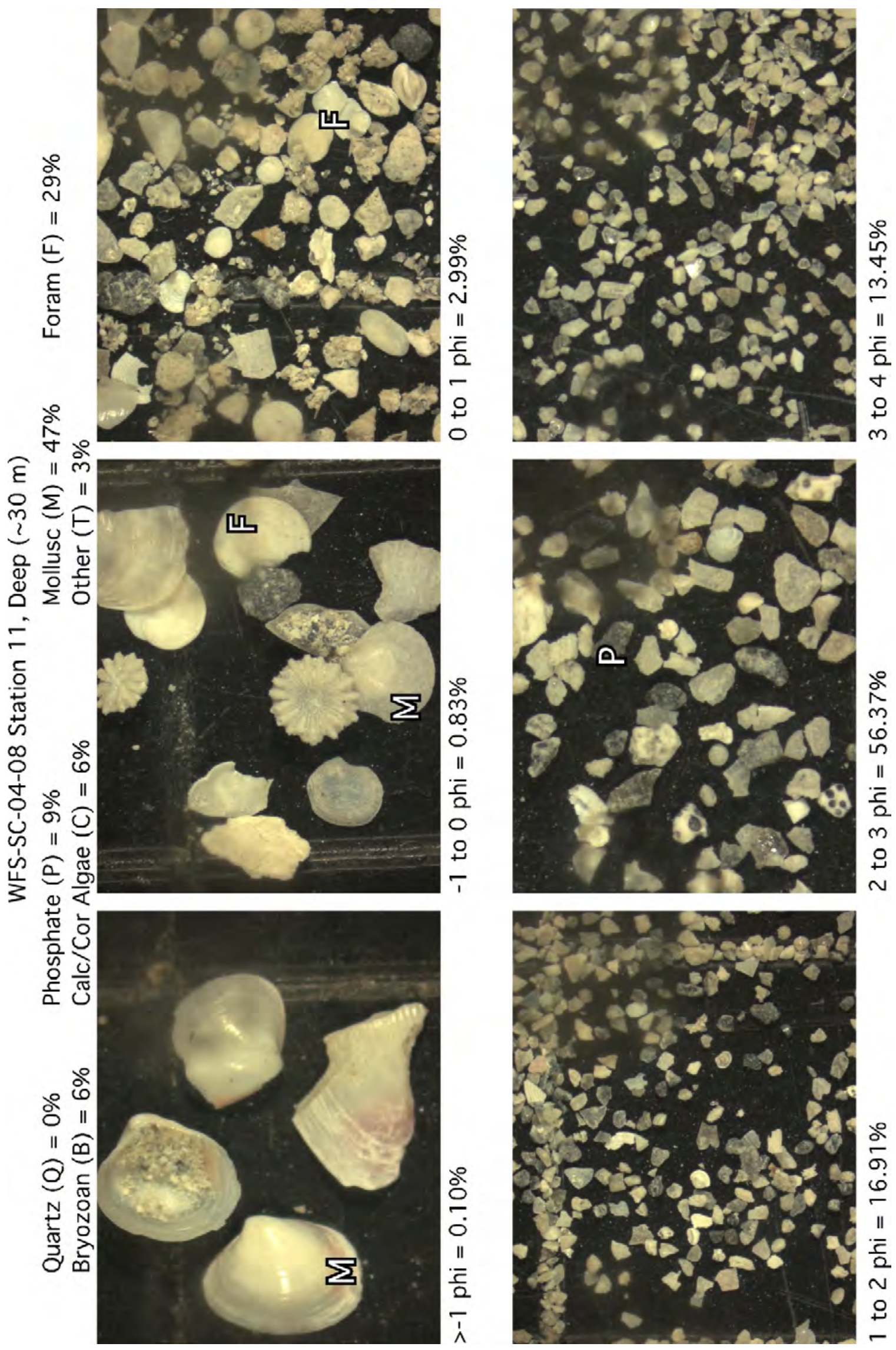

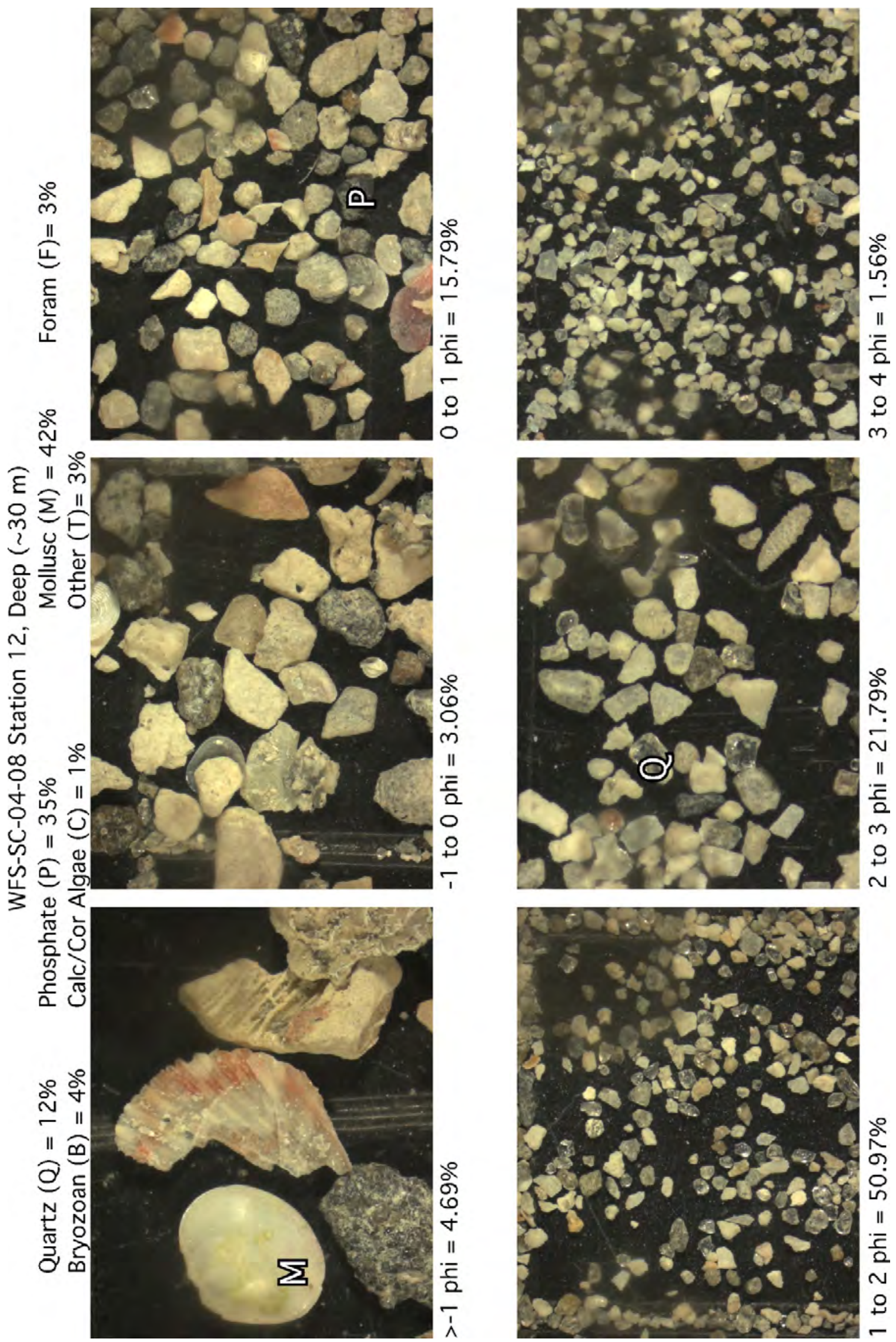

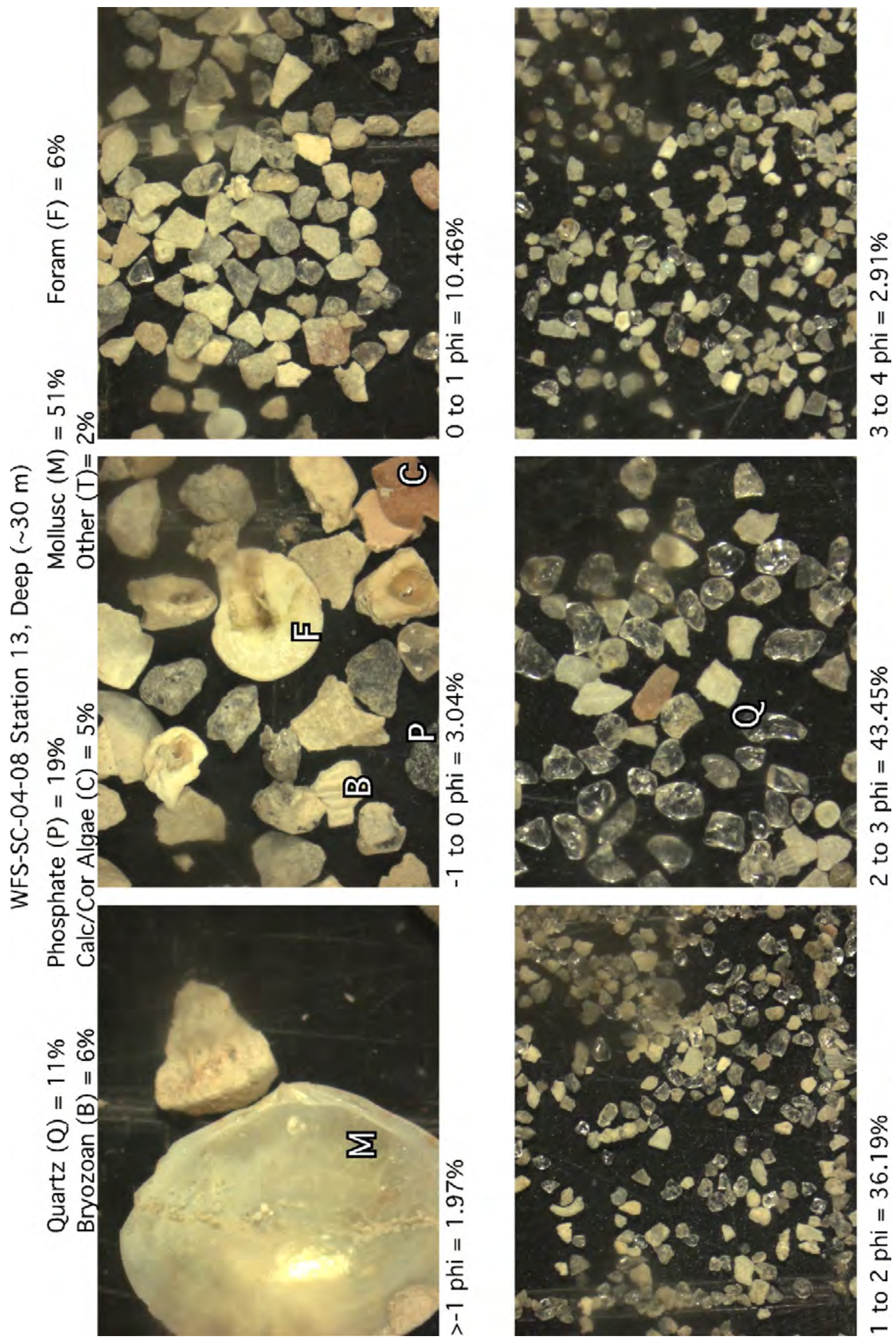

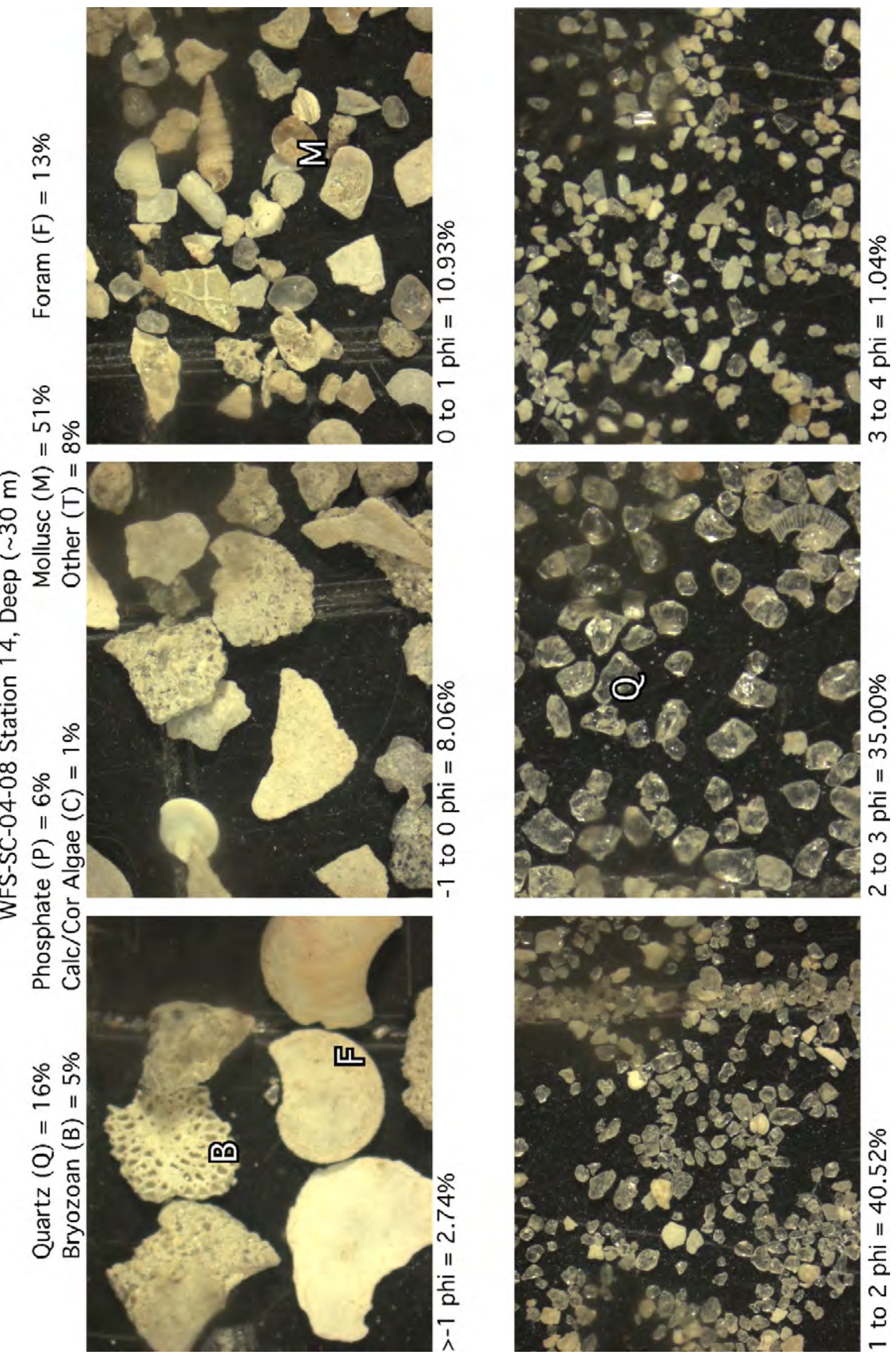

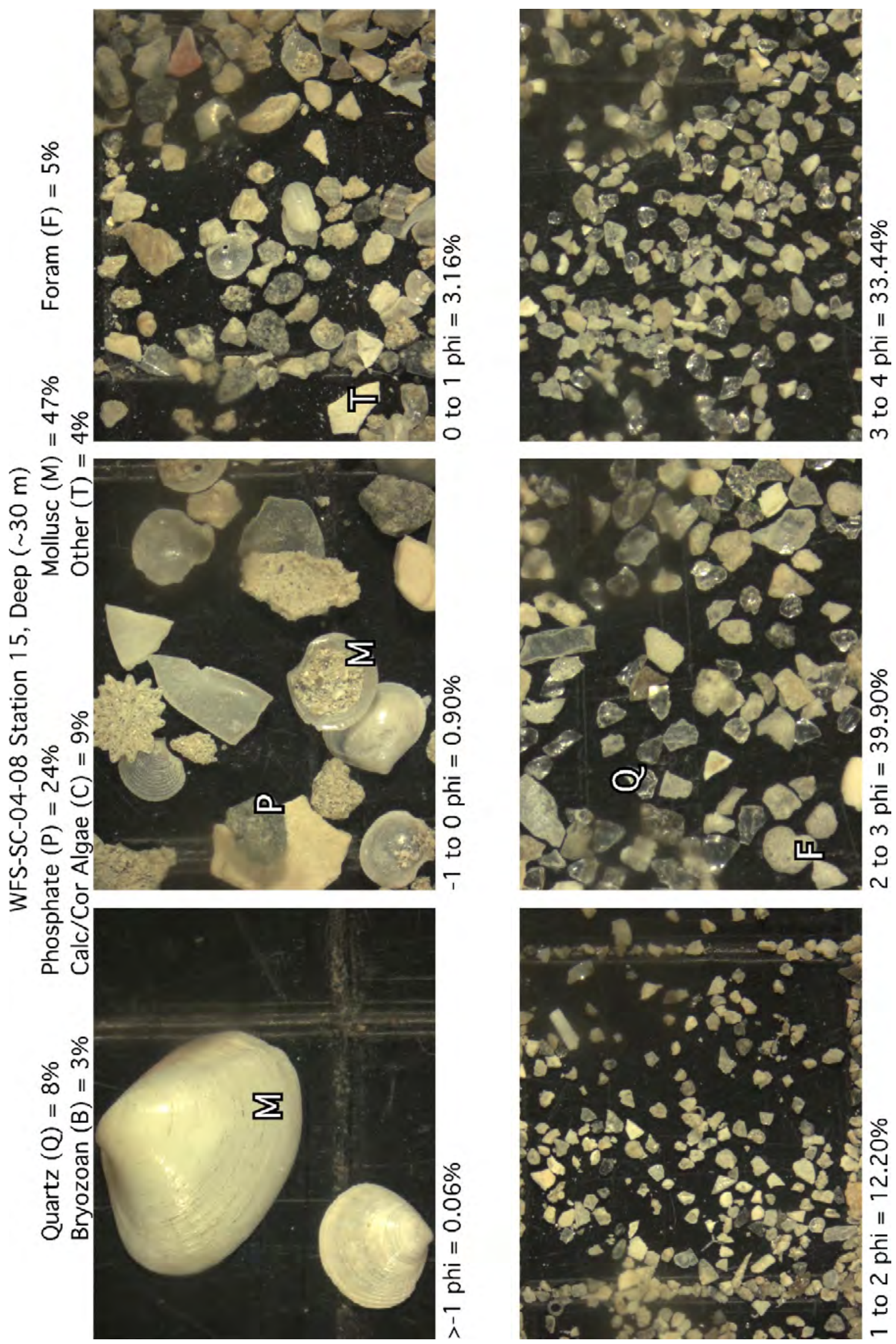

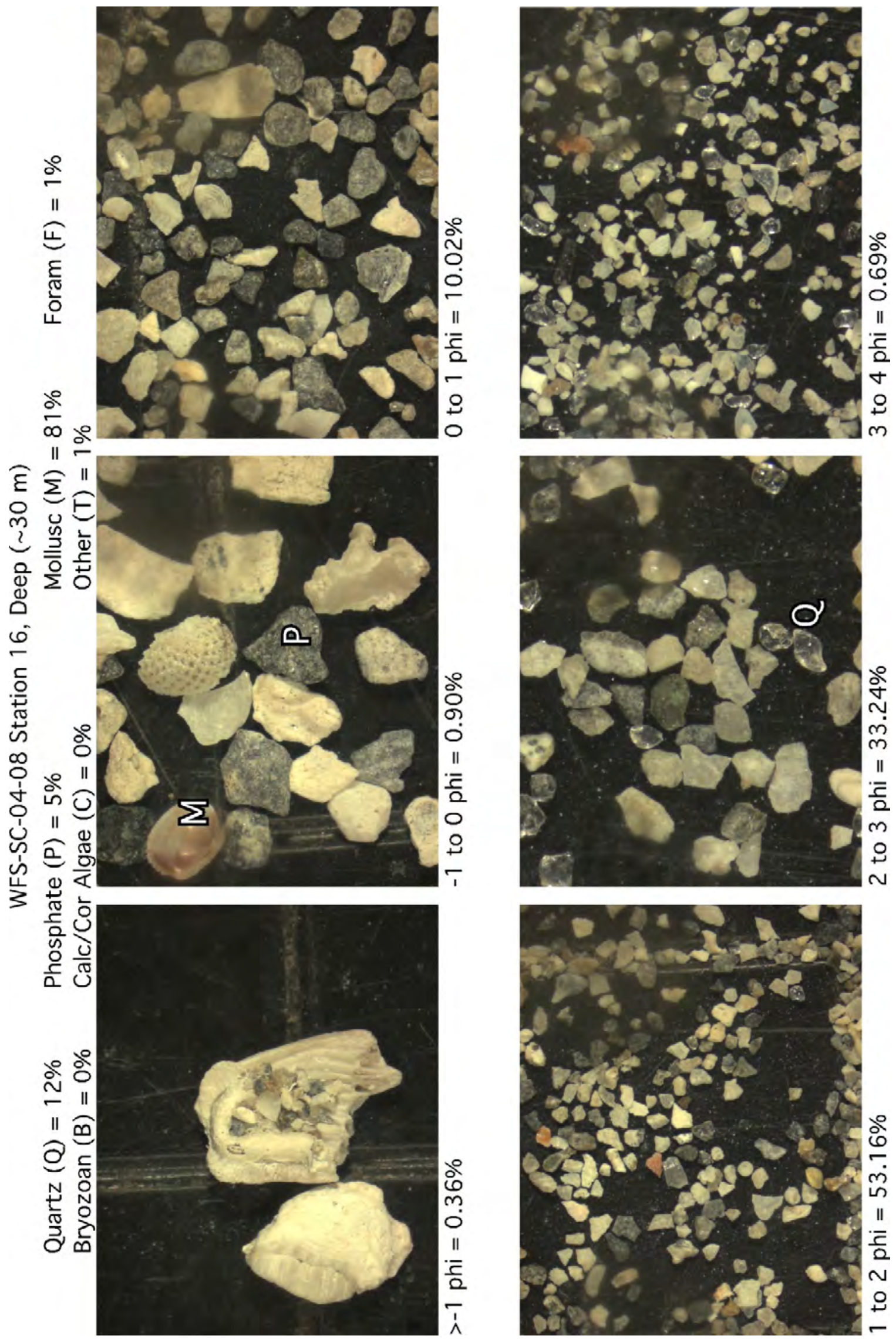

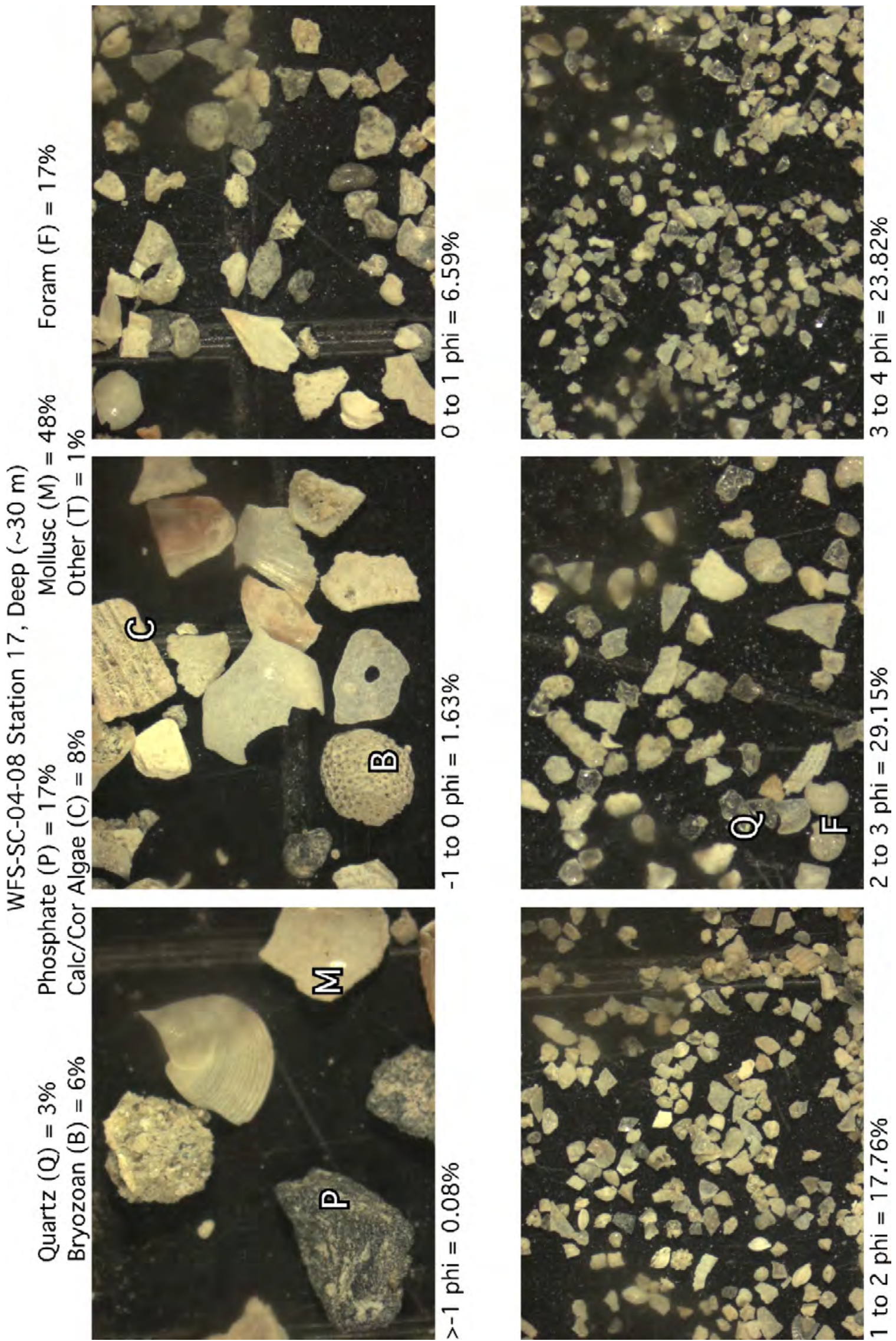

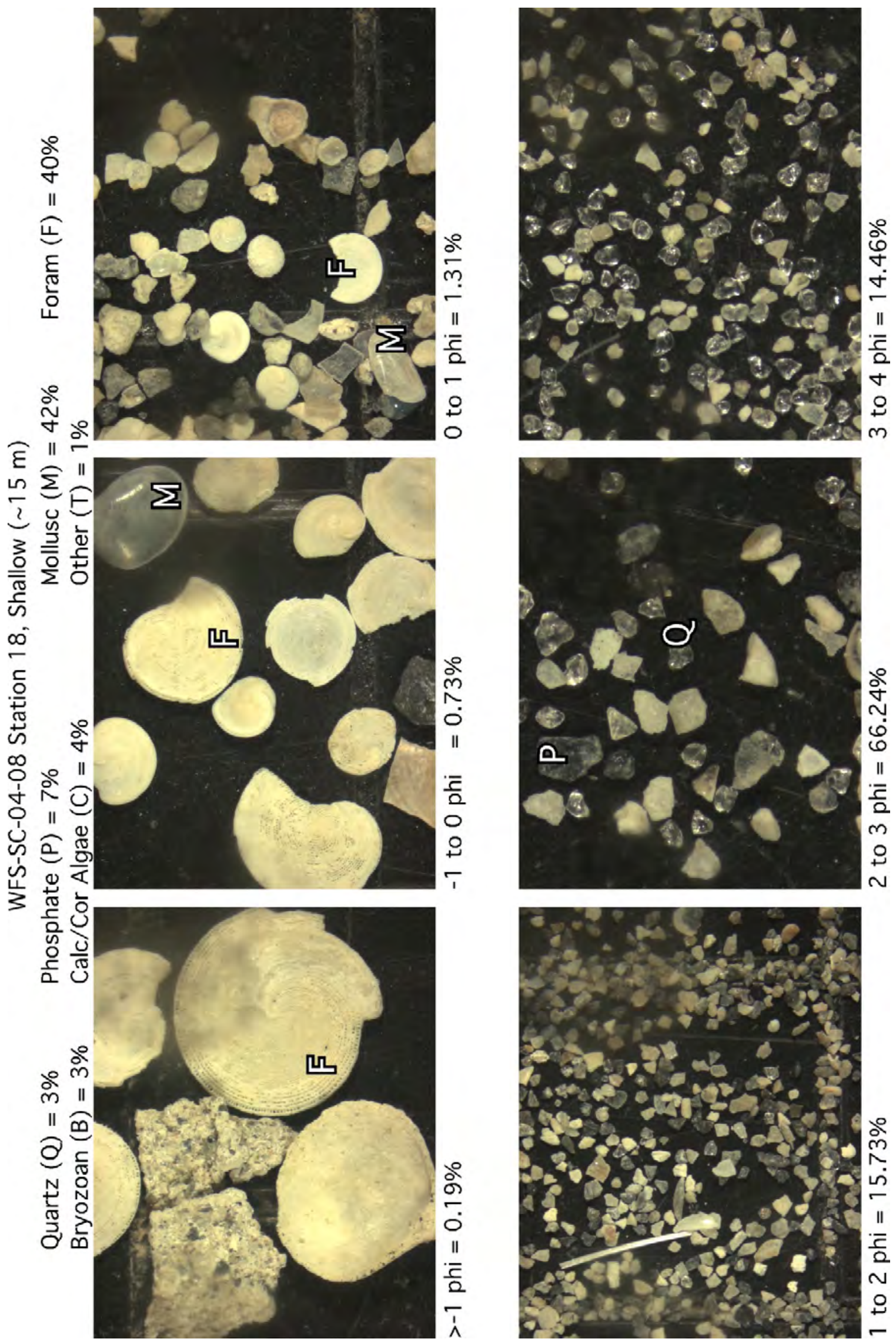
Appendix 1.4. Individual phi intervals for 15-m and 30-m depth contours from north to south. [Note, 2- to 3- and 3- to 4- $\phi$ photographs taken under increased magnification]

30 m Water Depth

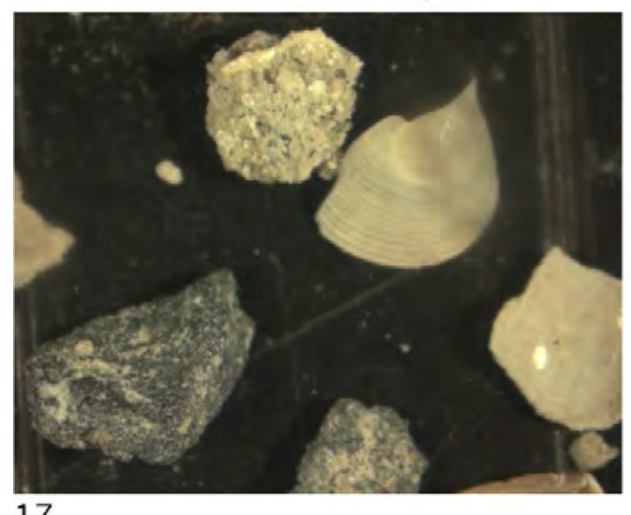

17

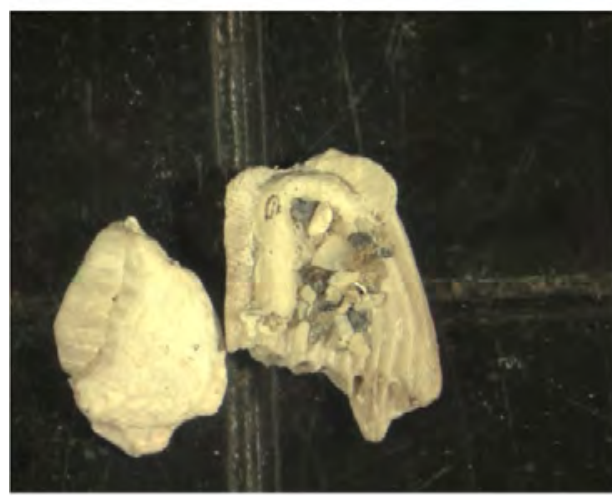

16

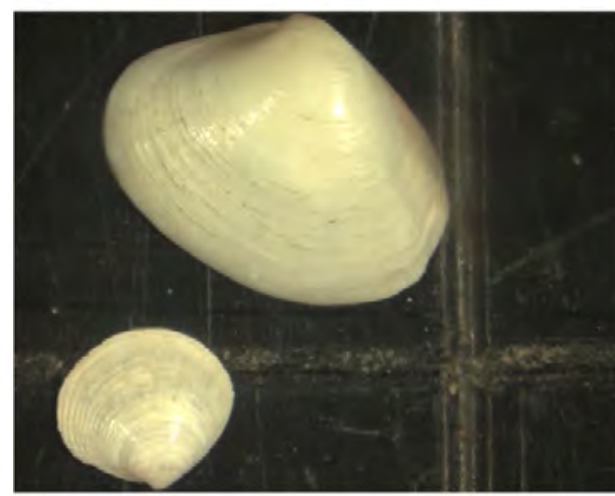

15

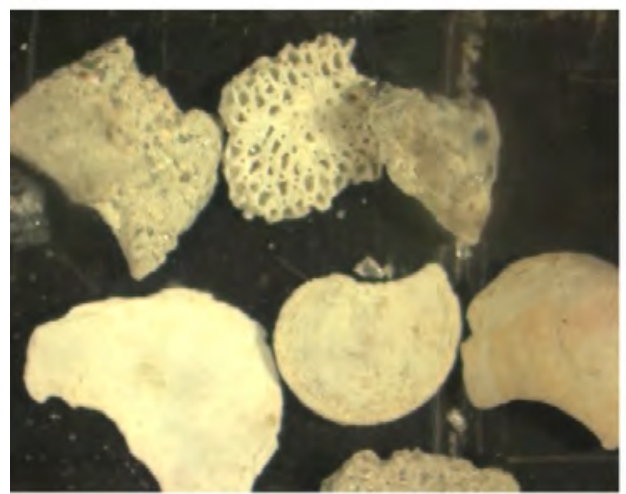

14
$15 \mathrm{~m}$ Water Depth

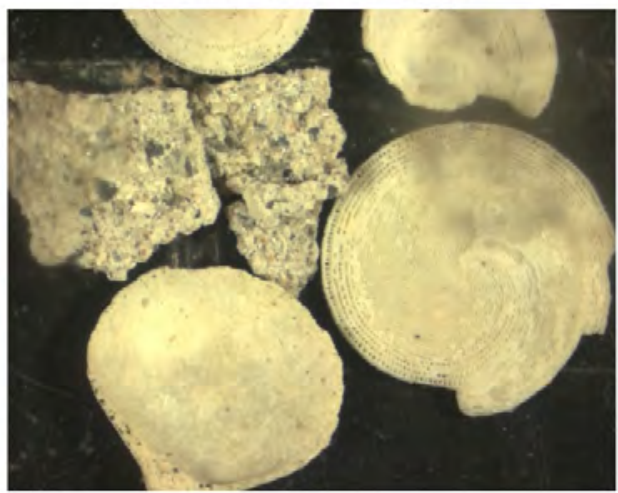

18

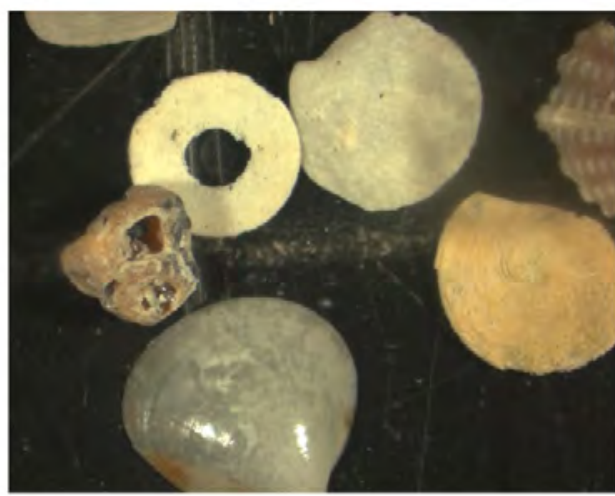

01

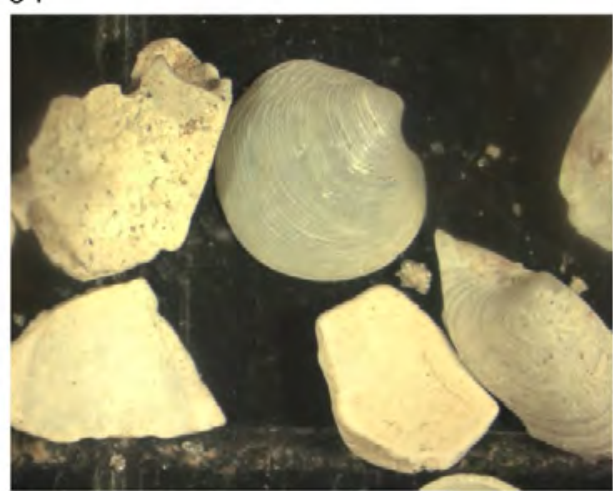

02

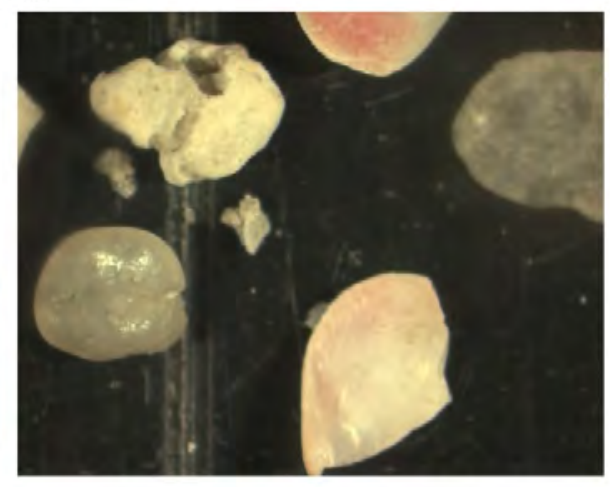

03
$>-1$ phi North 

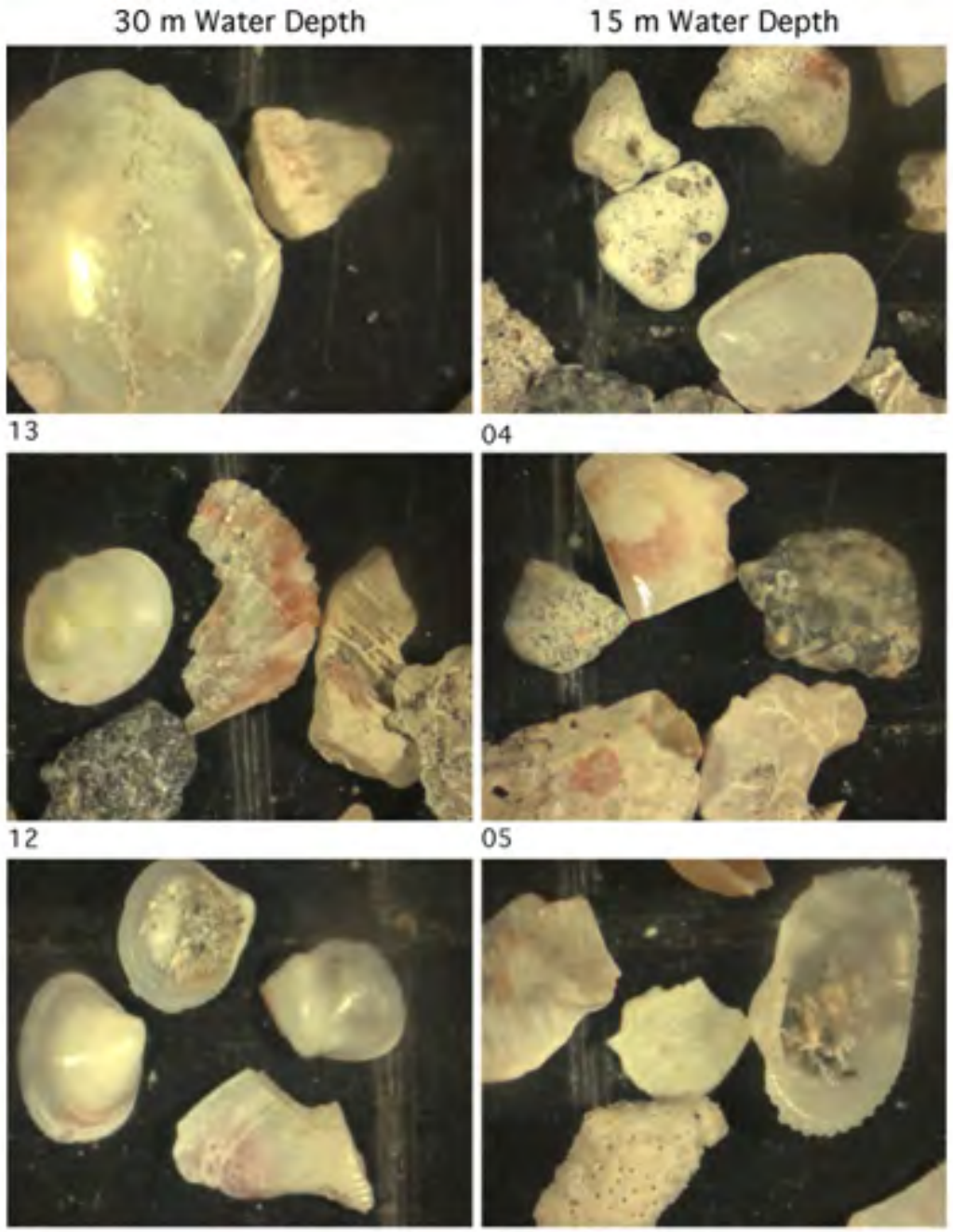

$>-1$ phi

South

11

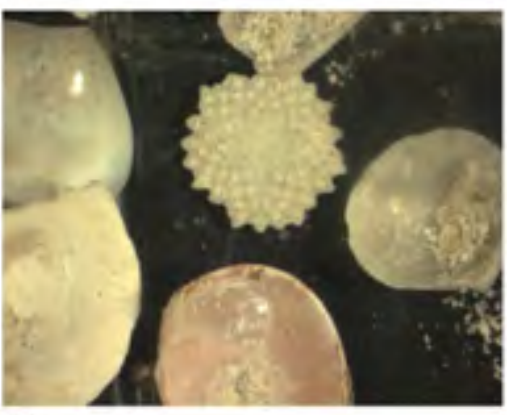

10

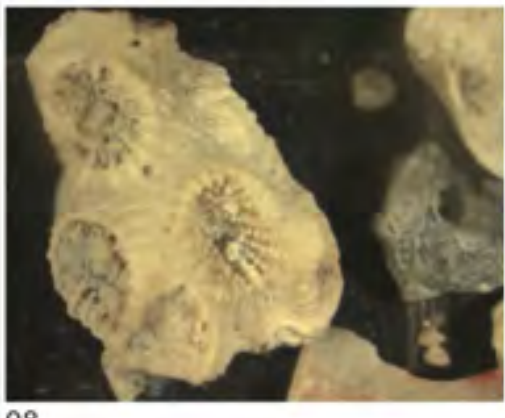

08
04

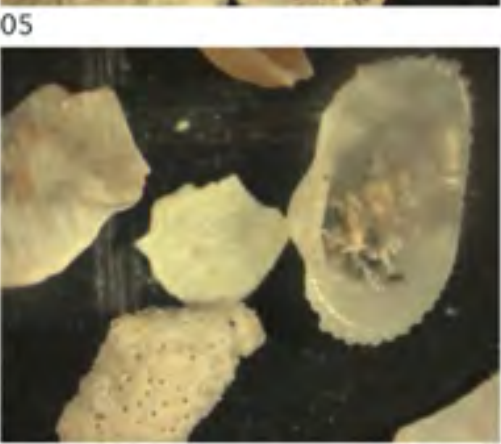

06

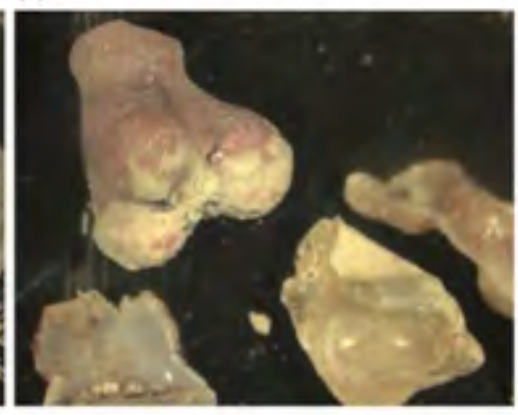

07

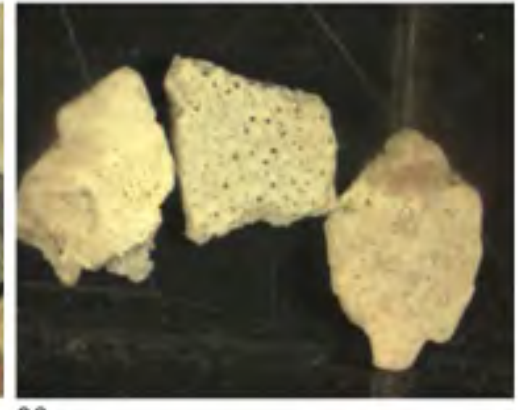

09 

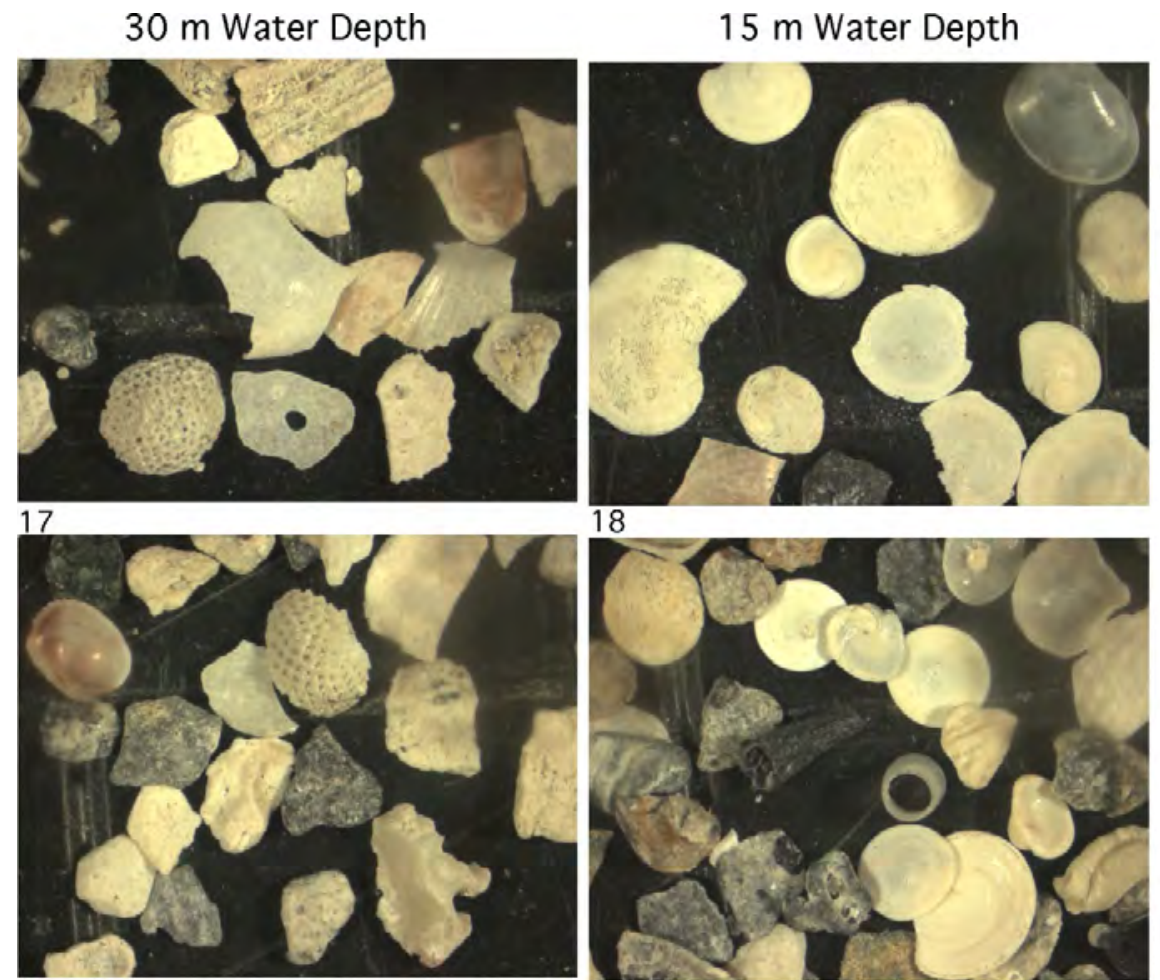

\section{-1 to 0 phi North}

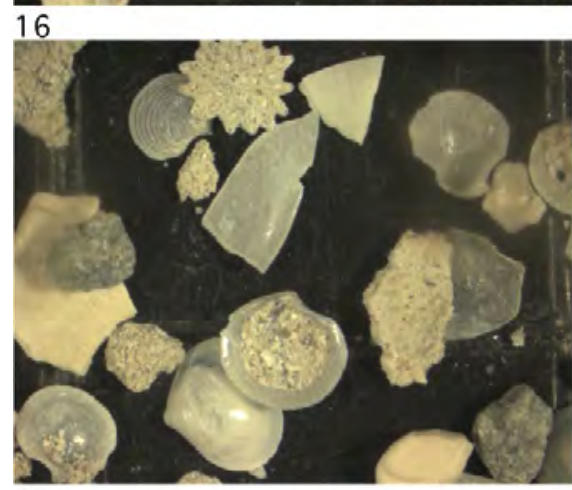

15
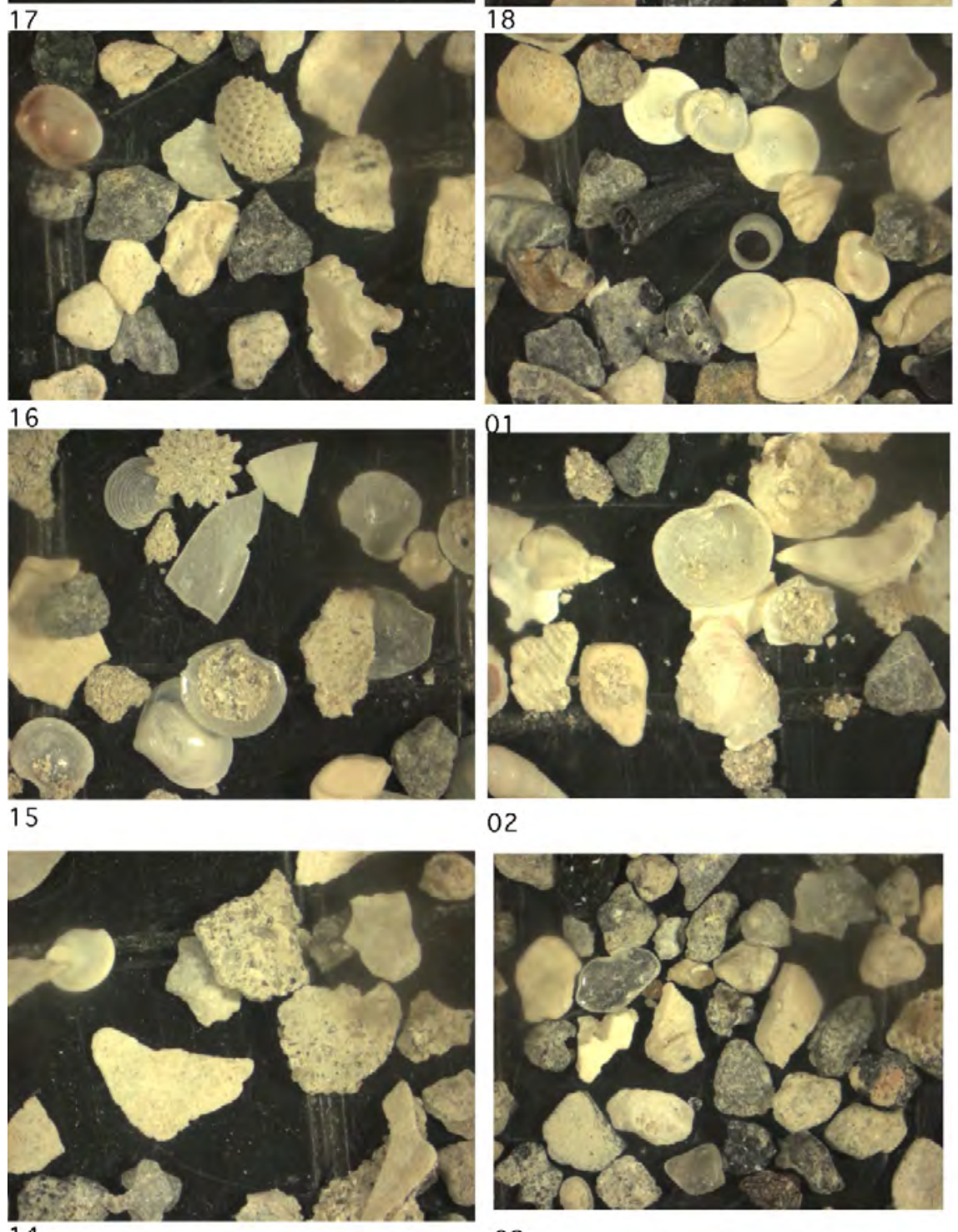

02

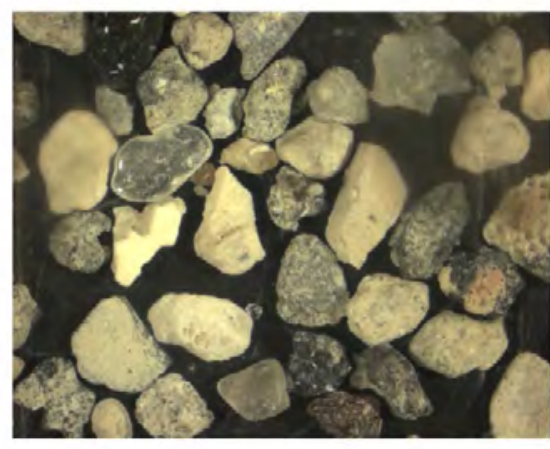



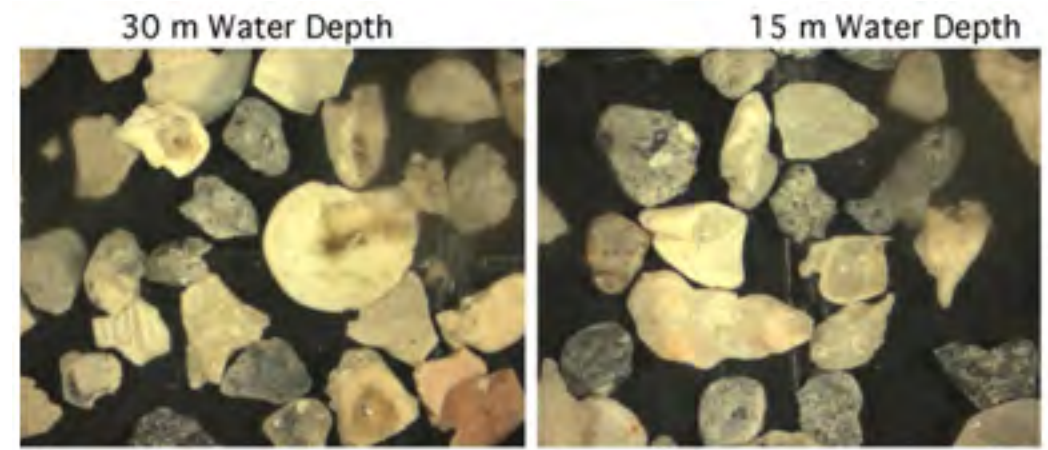

-1 to 0 phi South
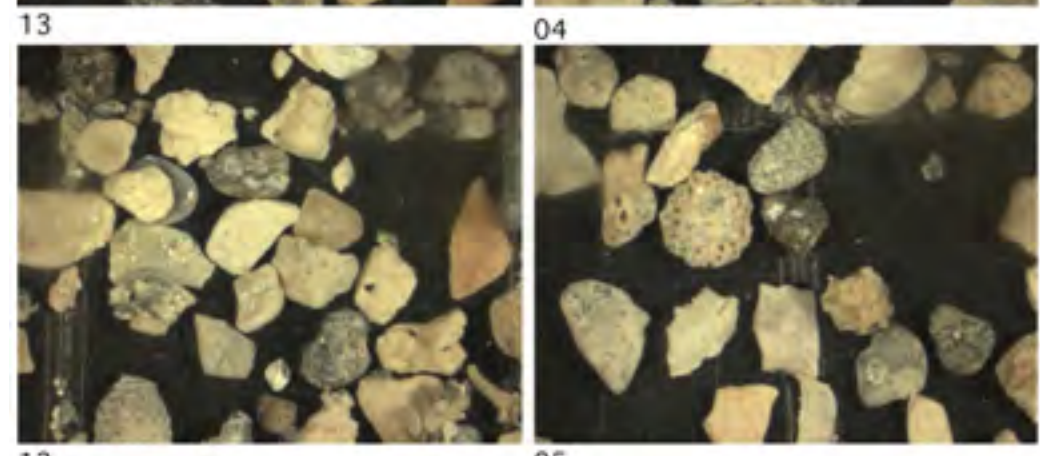

12

05
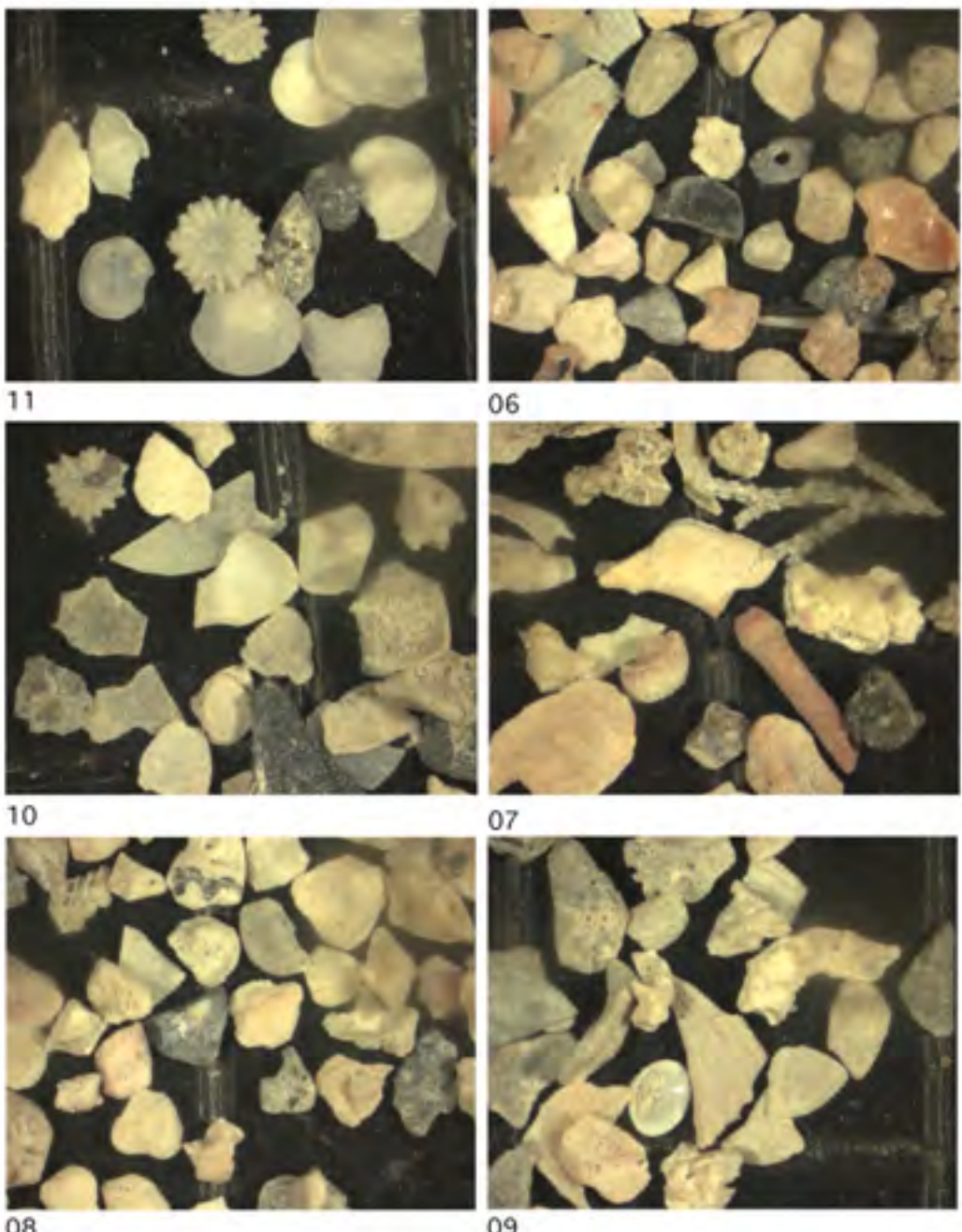

09 
$30 \mathrm{~m}$ Water Depth
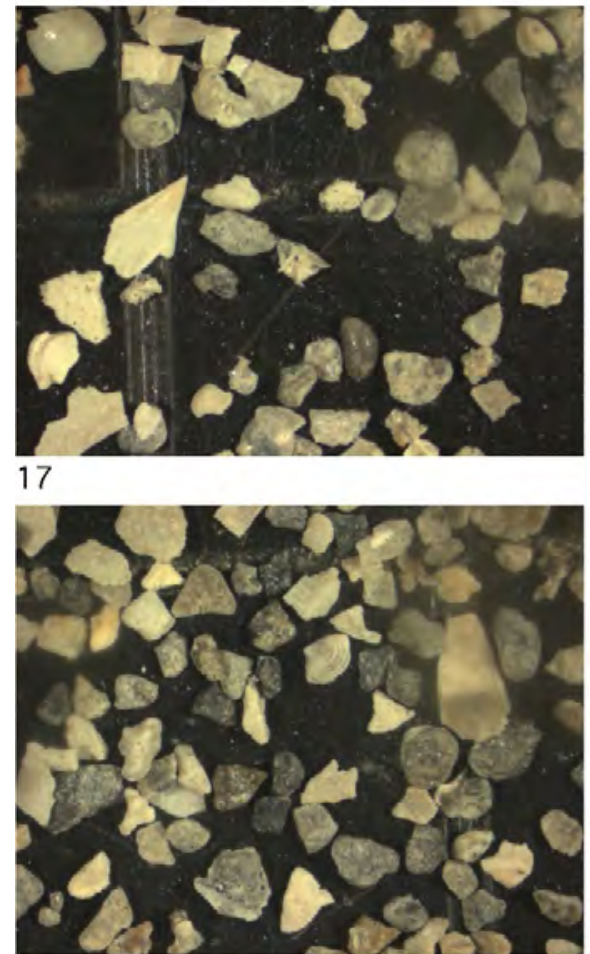

16

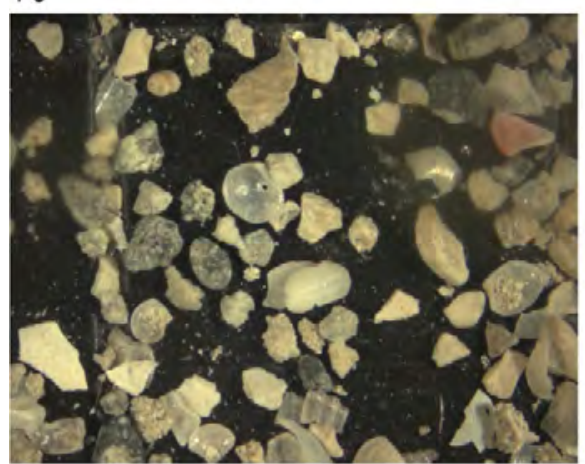

15

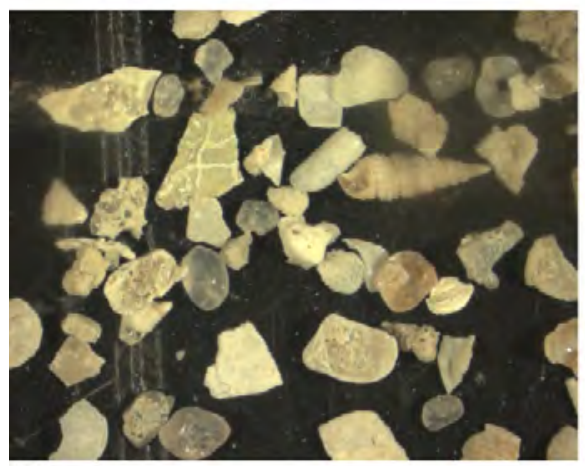

14
15 m Water Depth

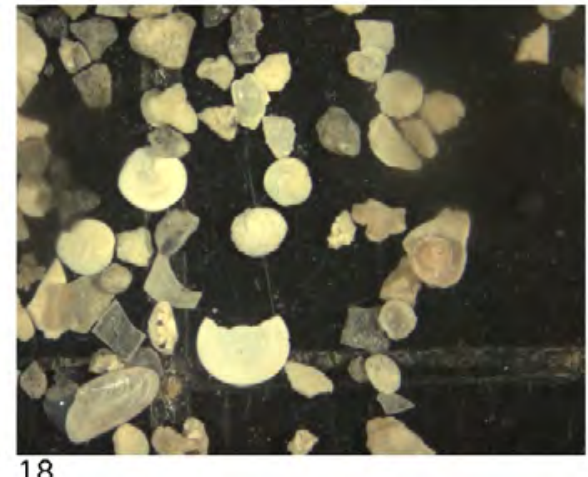

0 to 1 phi North
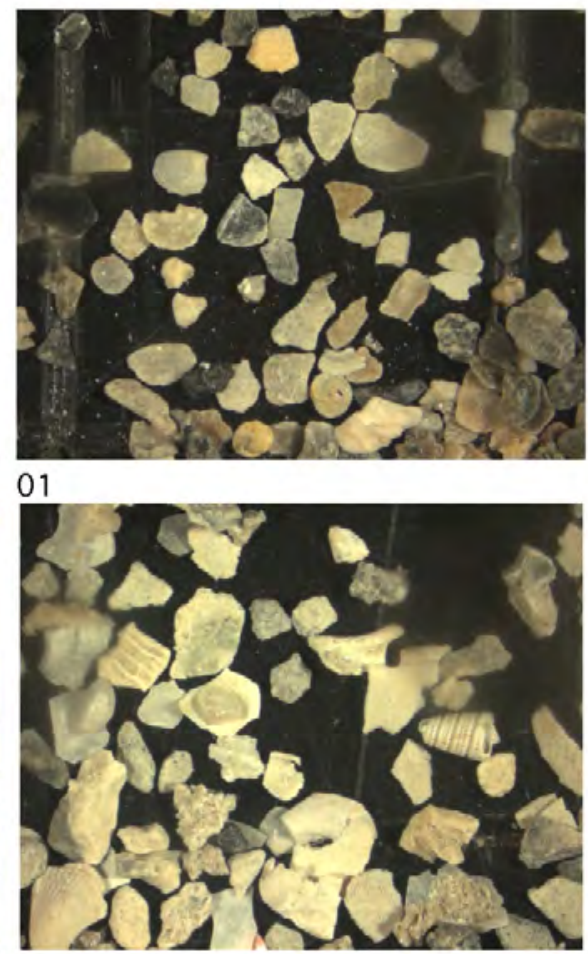

02

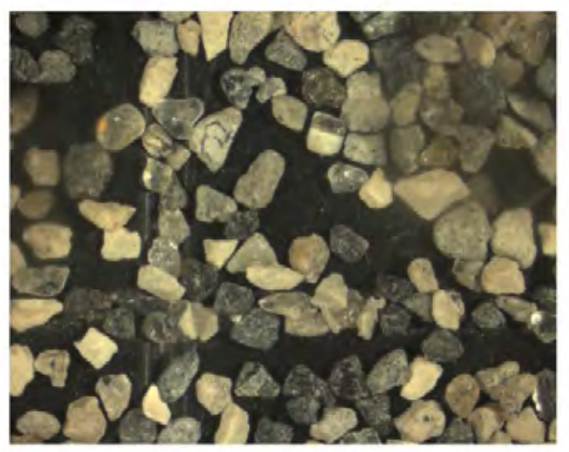

03 

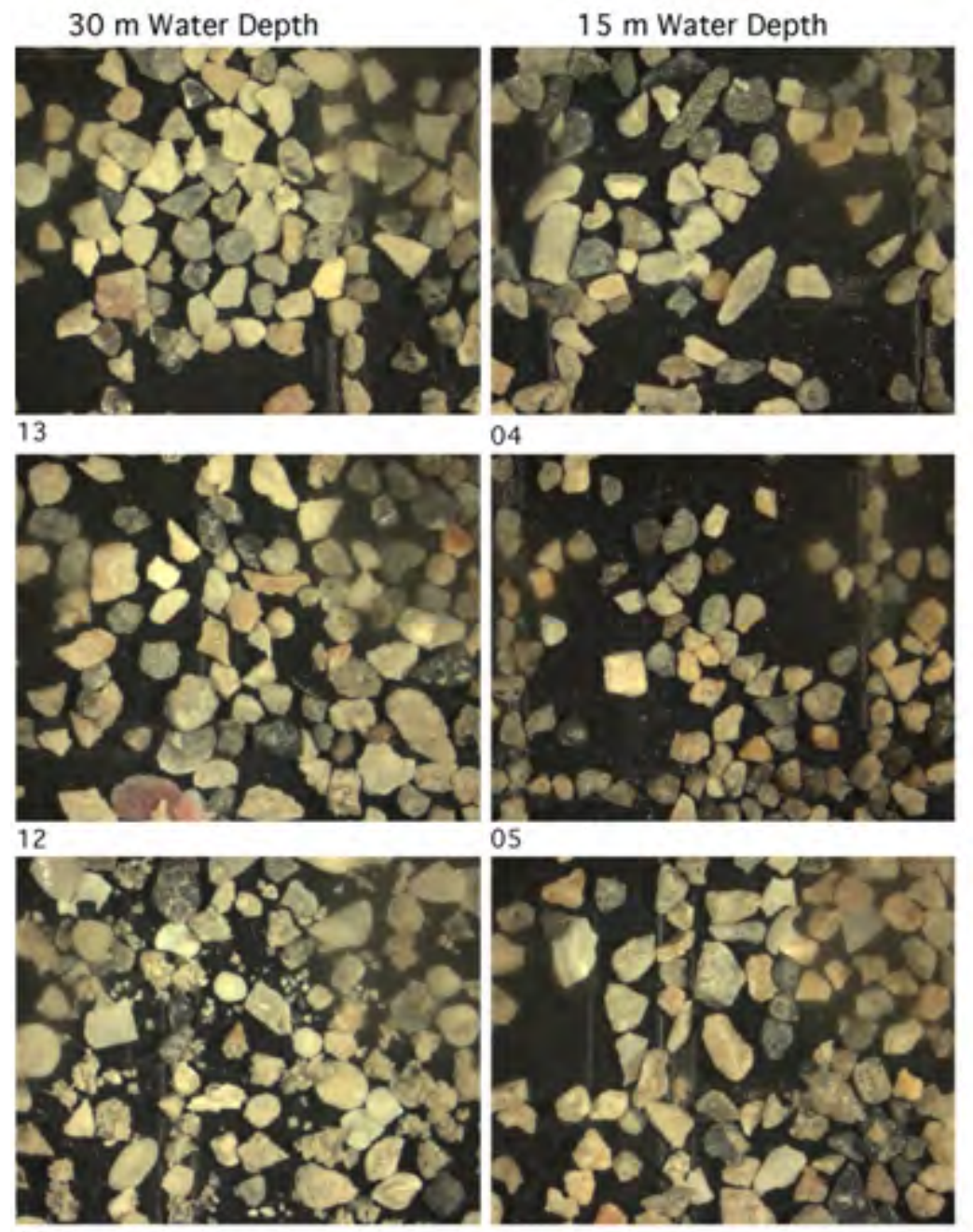

0 to 1 phi South

11

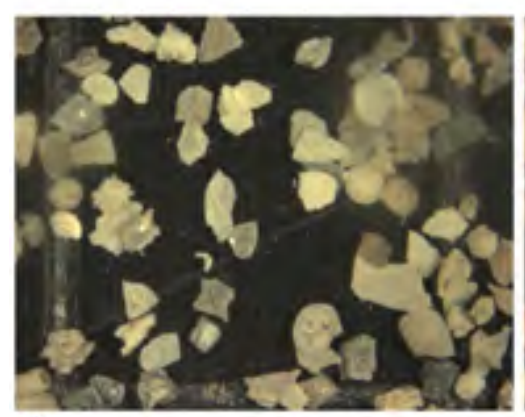

10

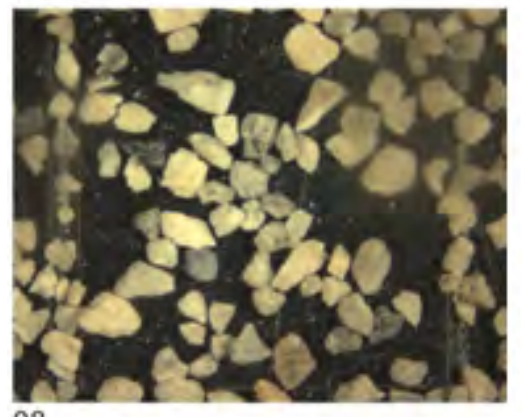

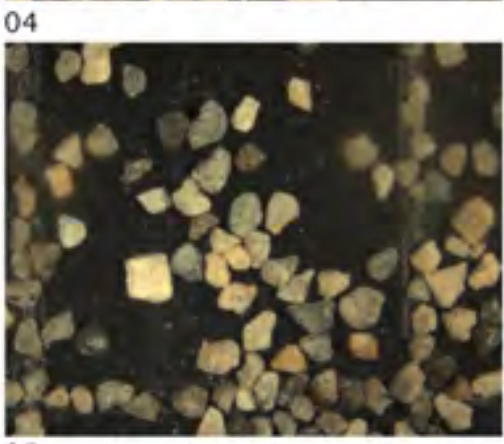

05

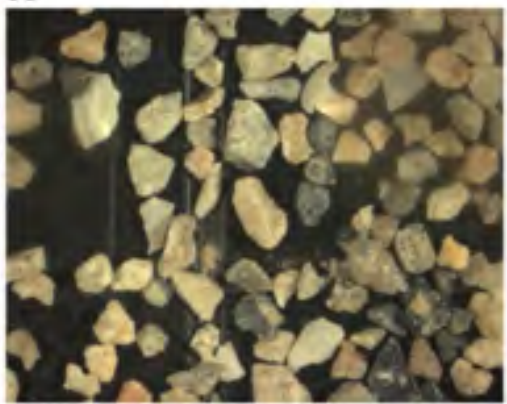

06

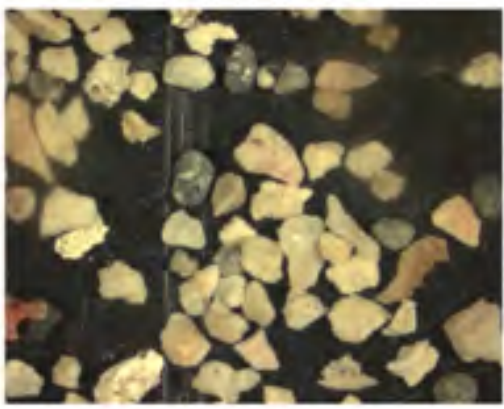

n7

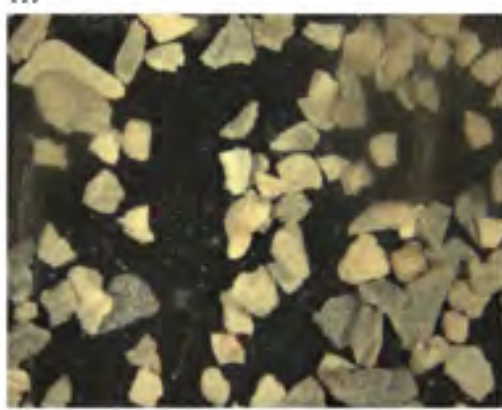

09 

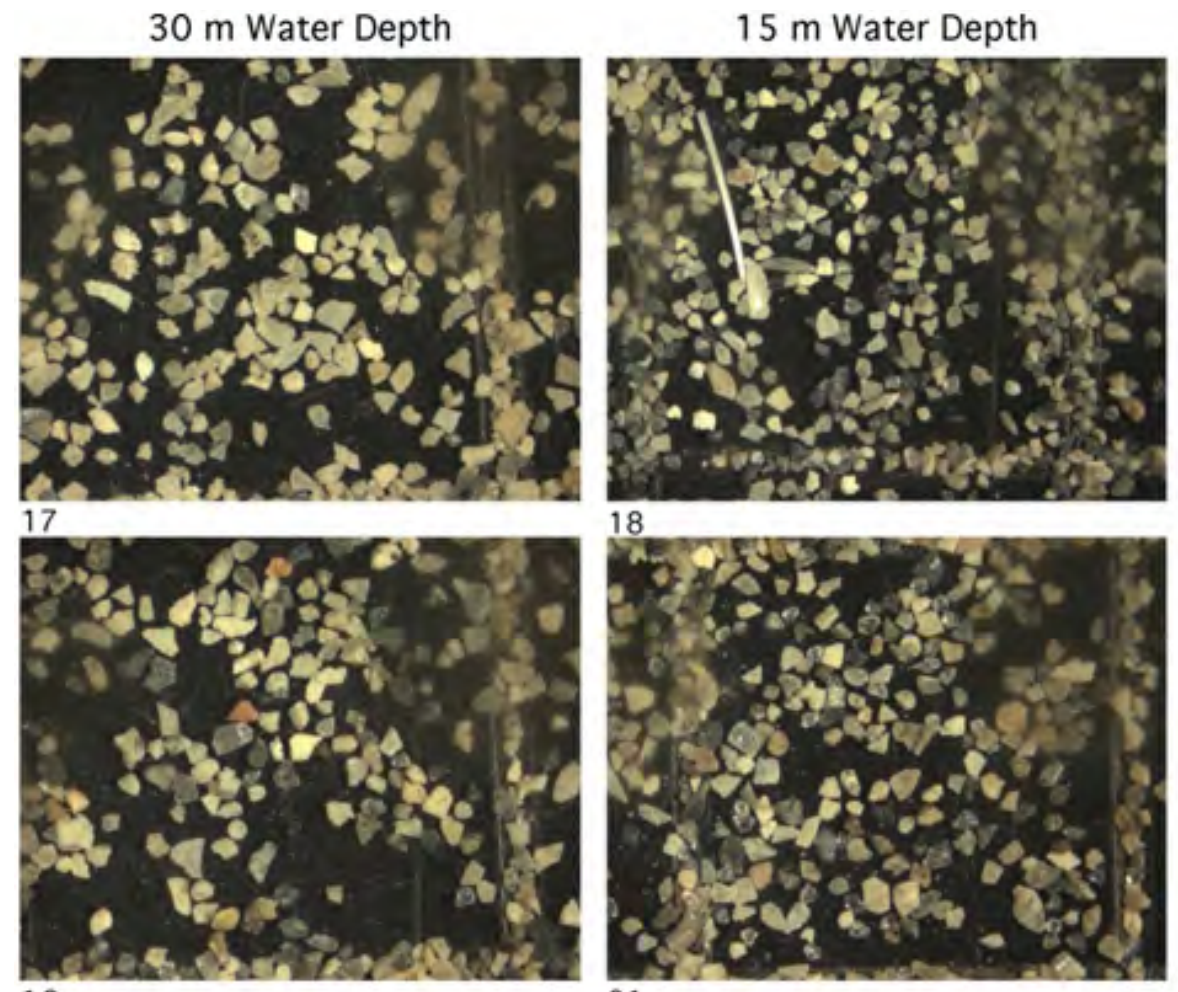

\section{1 to 2 phi North}

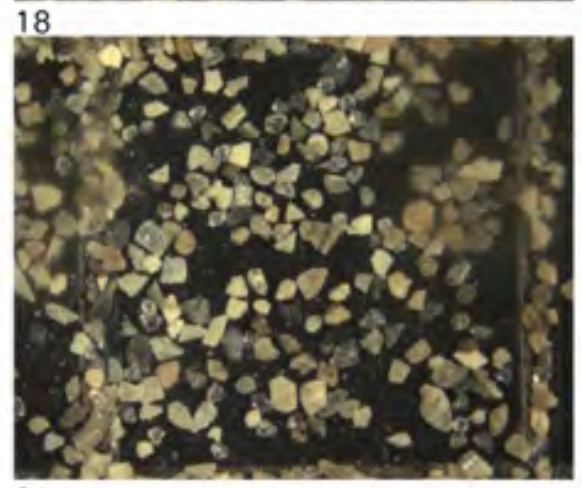

16

01

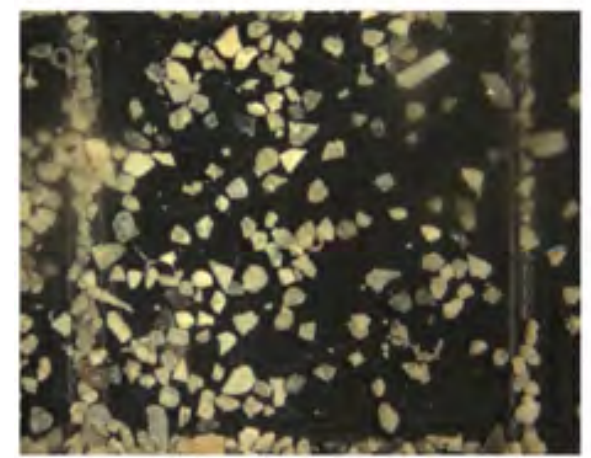

15

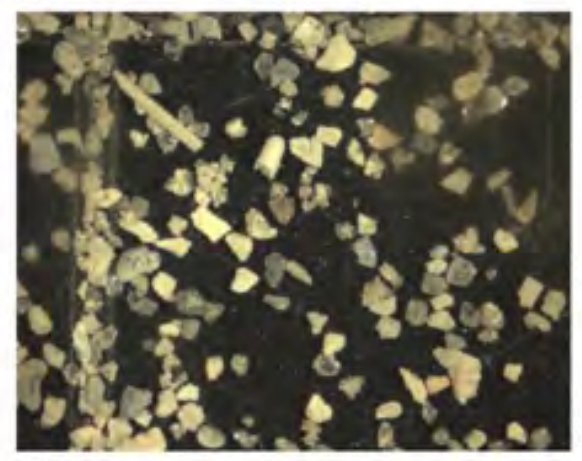

02
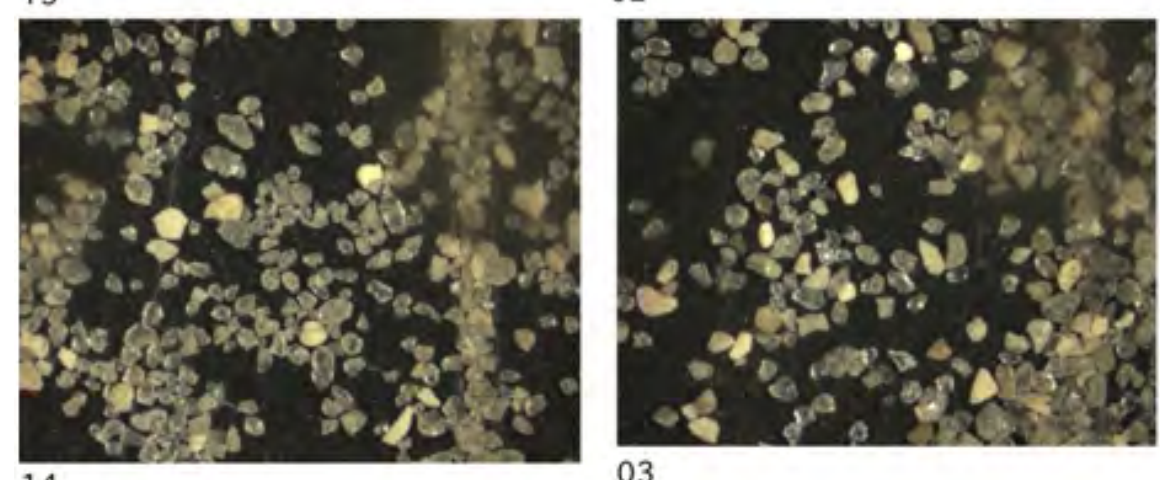

03 

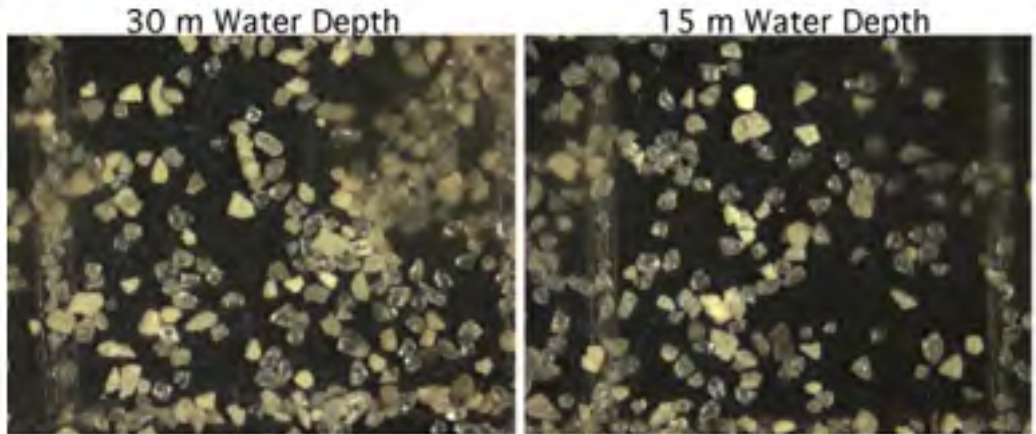

\section{1 to 2 phi South}
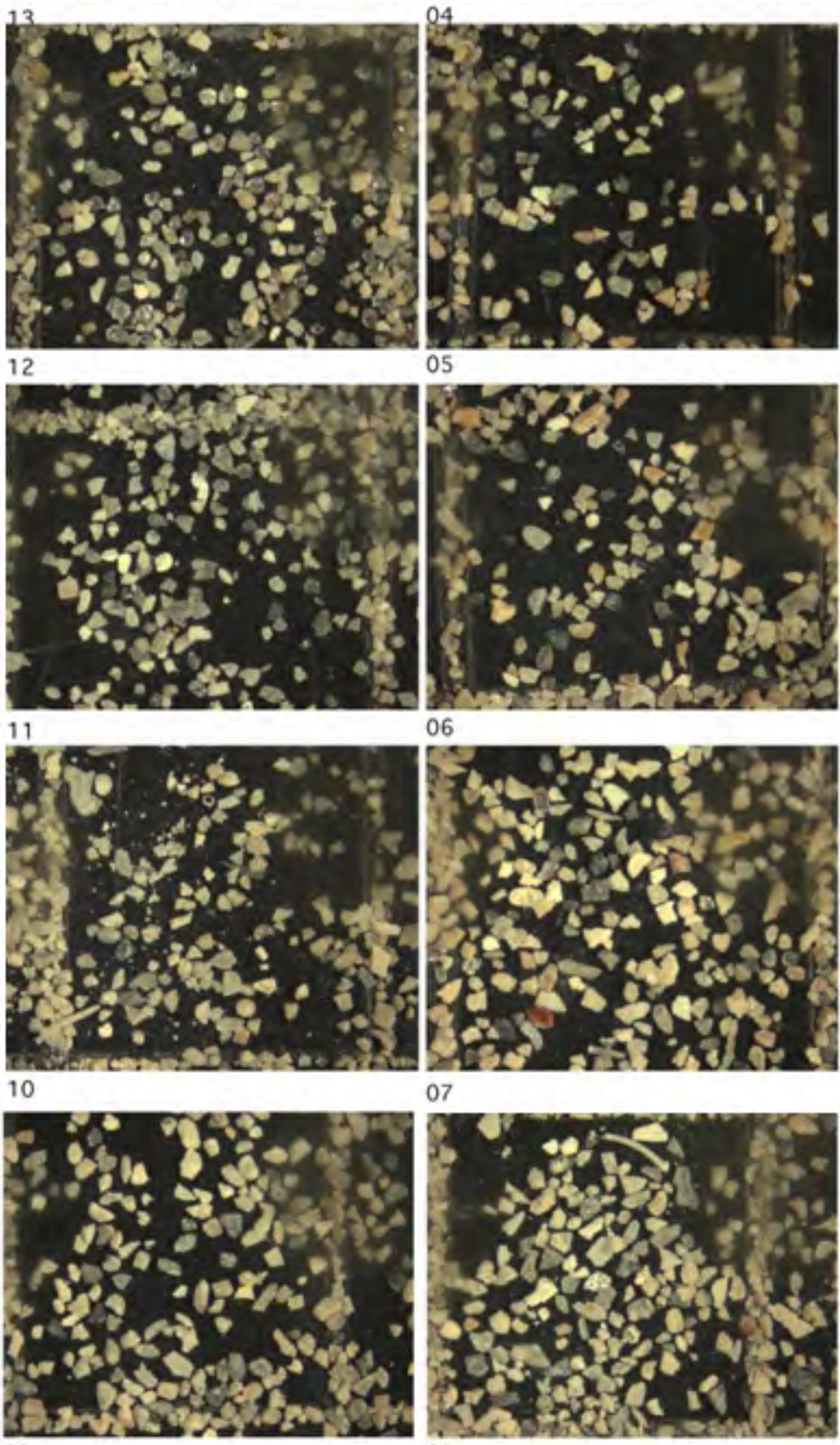

08

09 

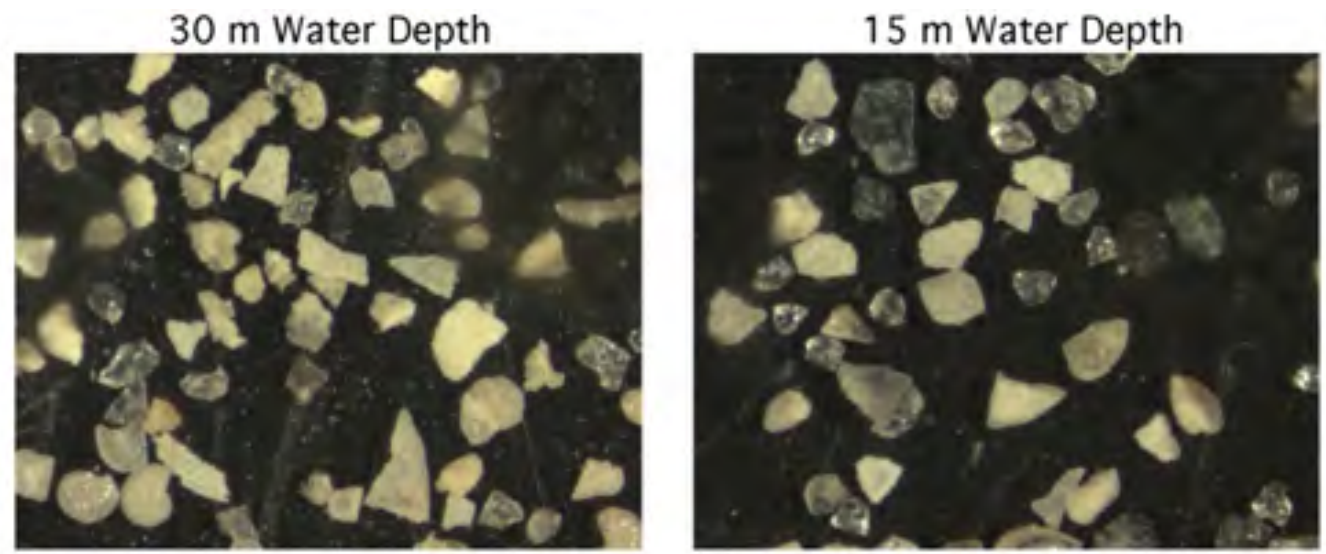

\section{2 to 3 phi} North
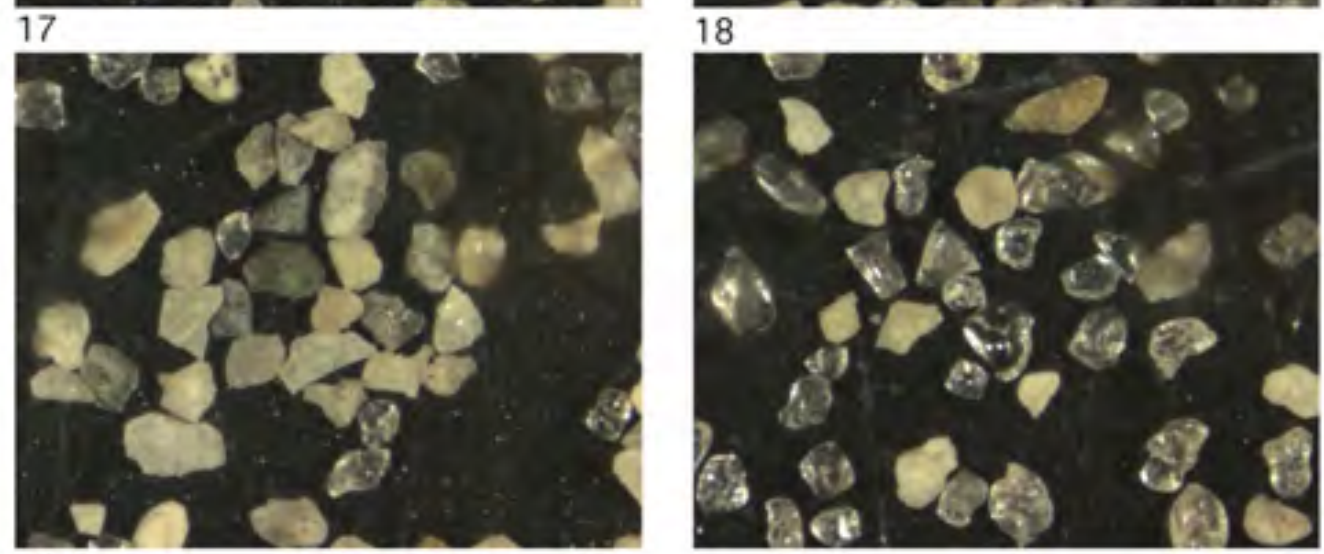

16

01

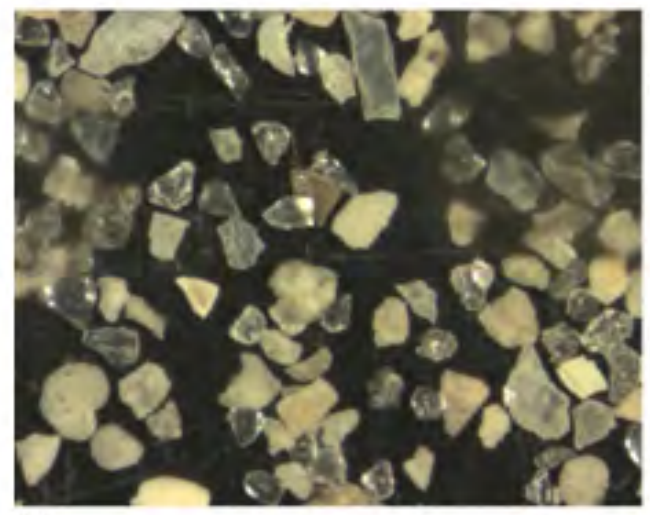

15
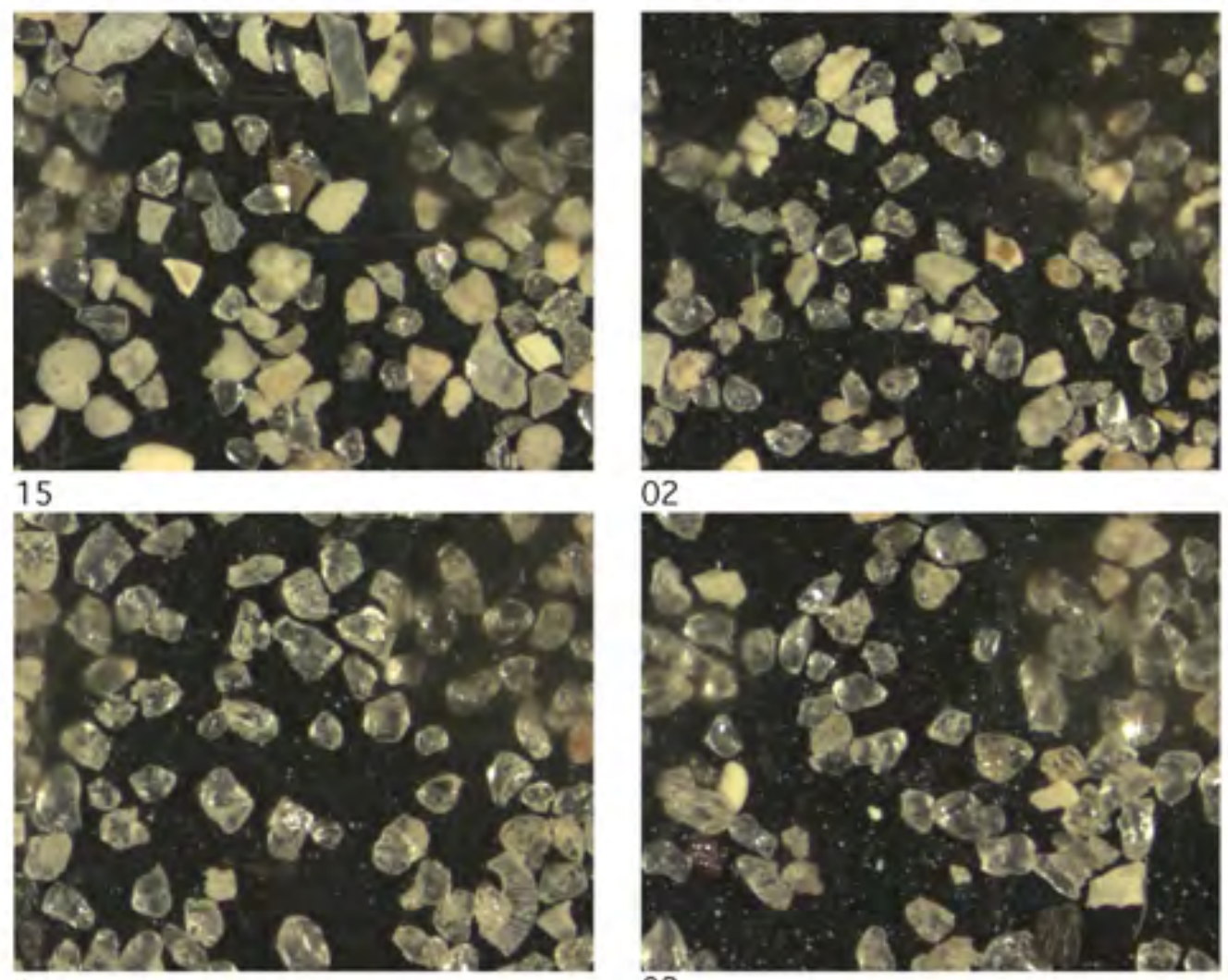

02

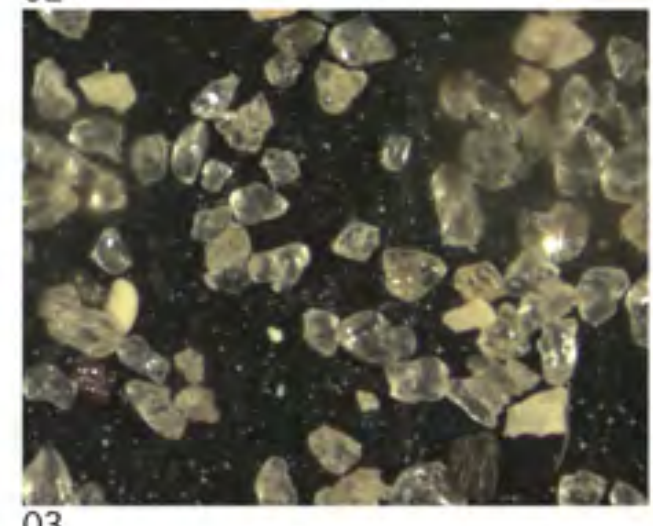



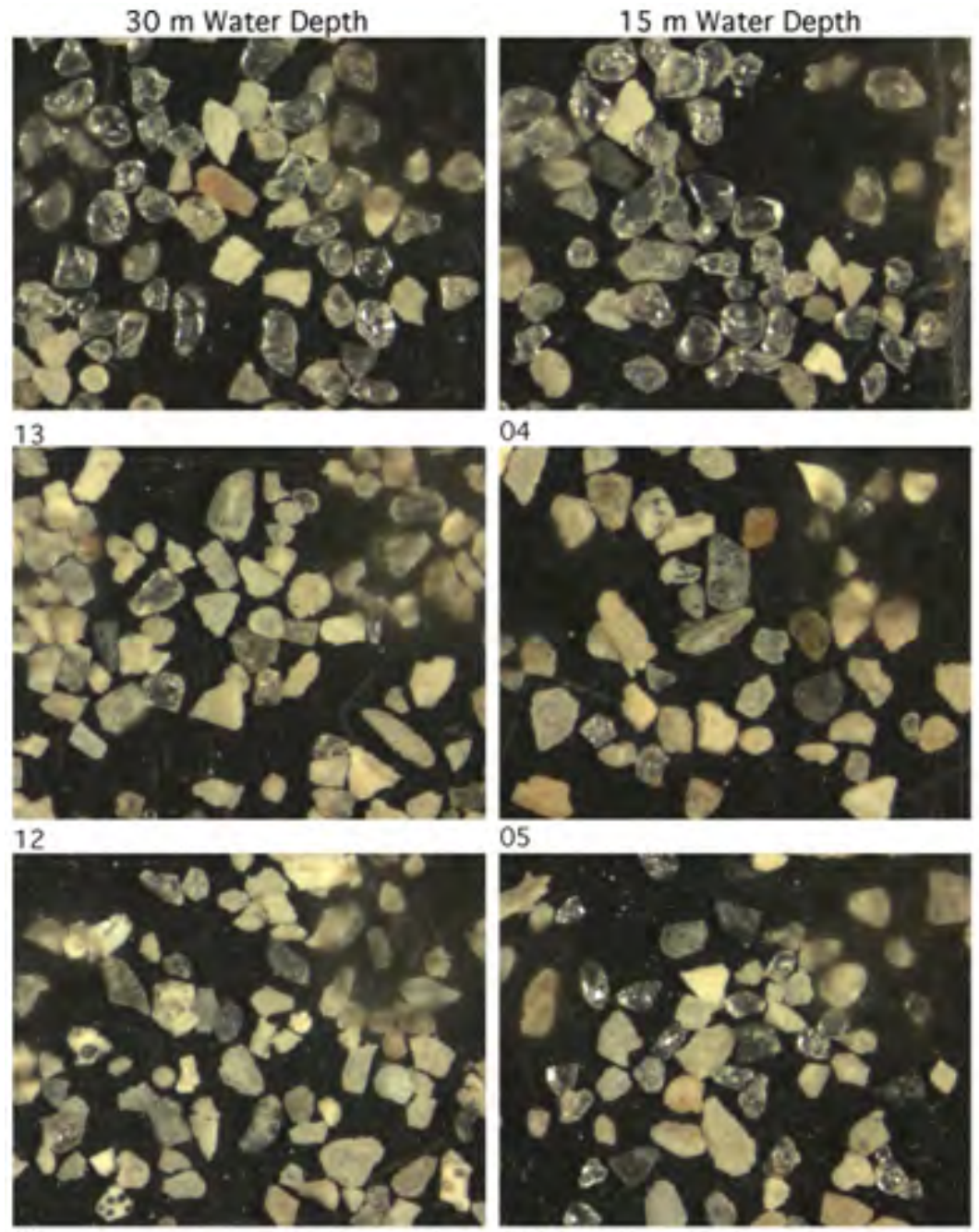

2 to 3 phi

South
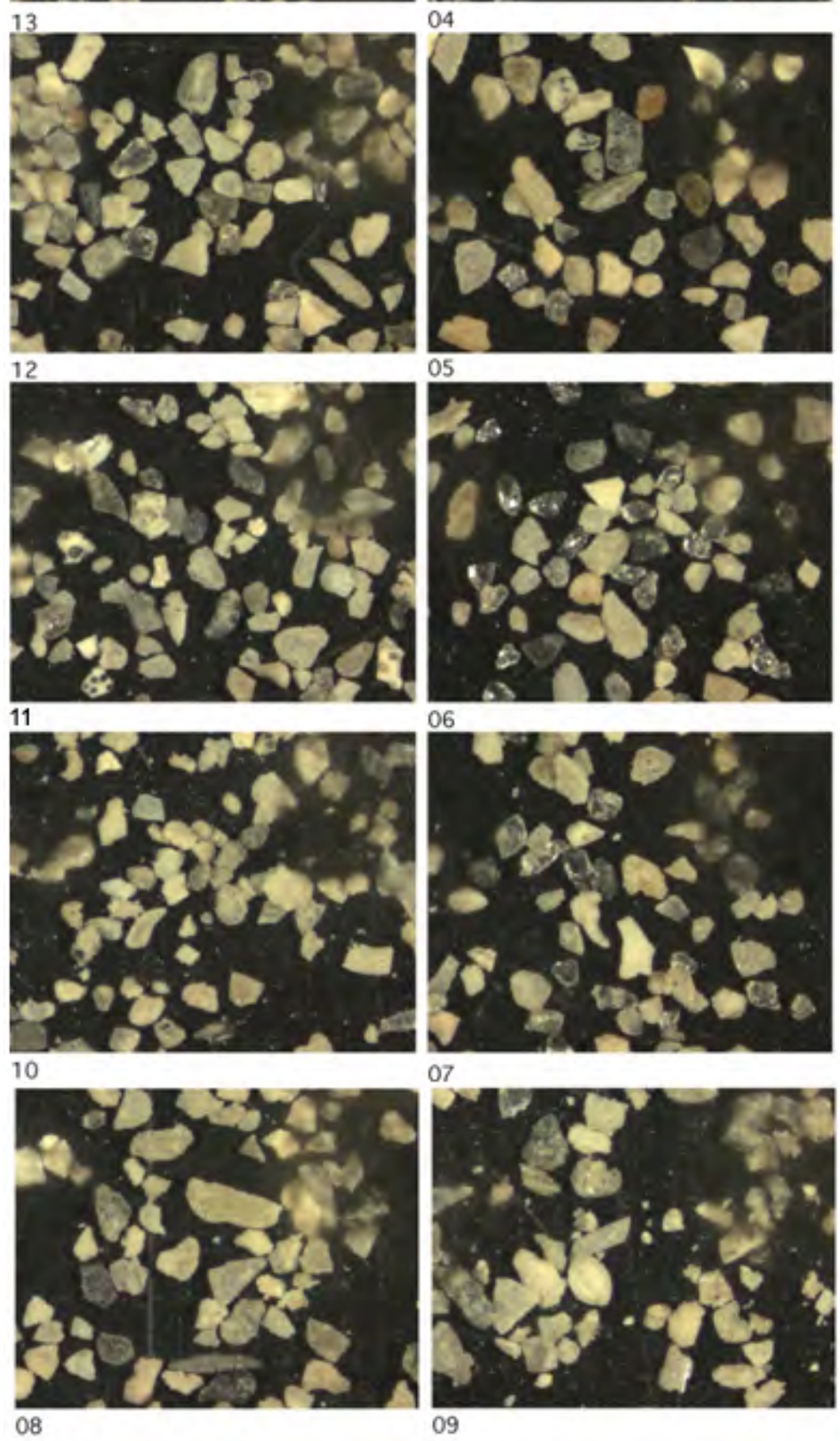

09 

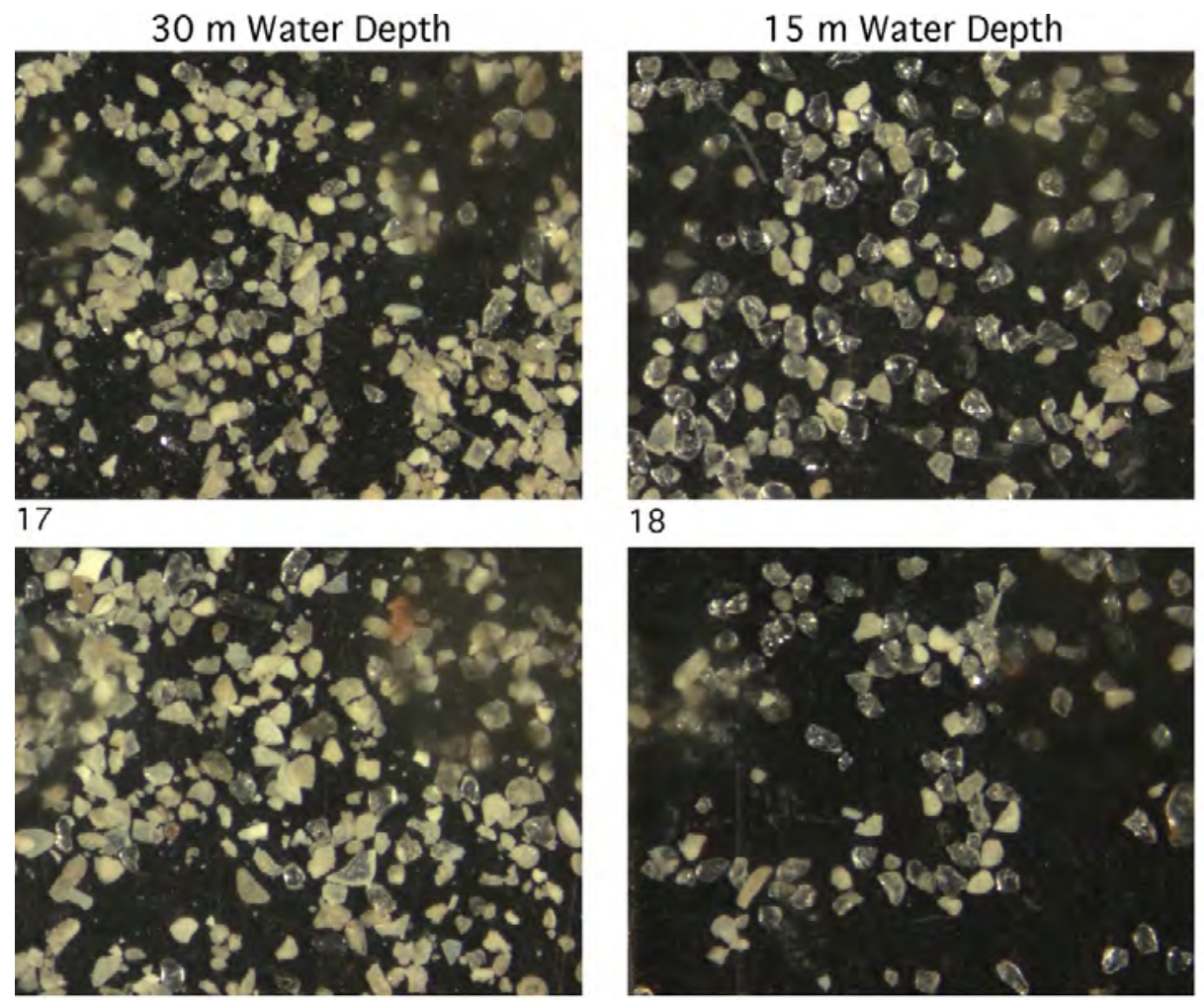

3-4 phi North

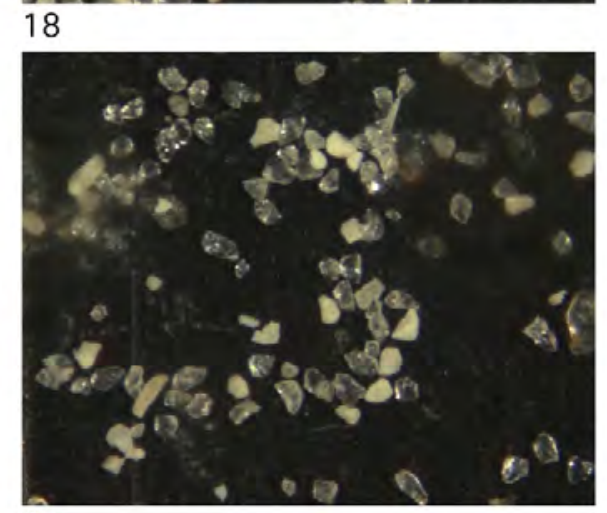

16

01

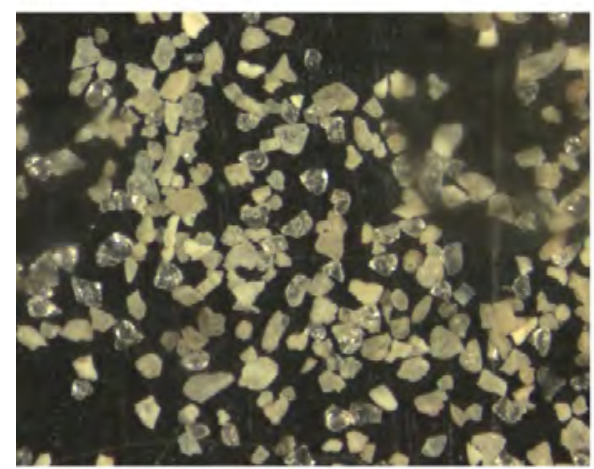

15

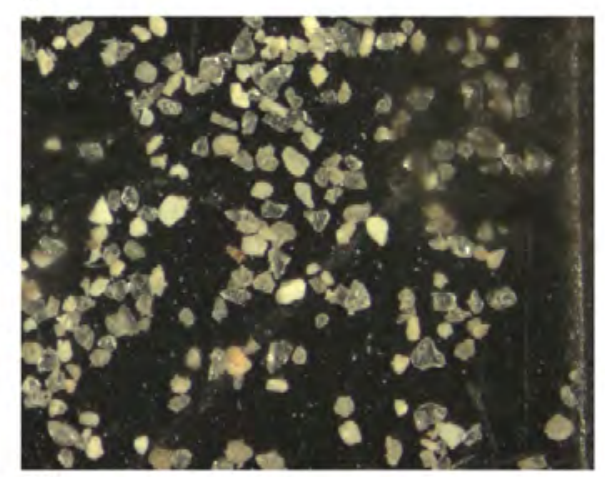

02
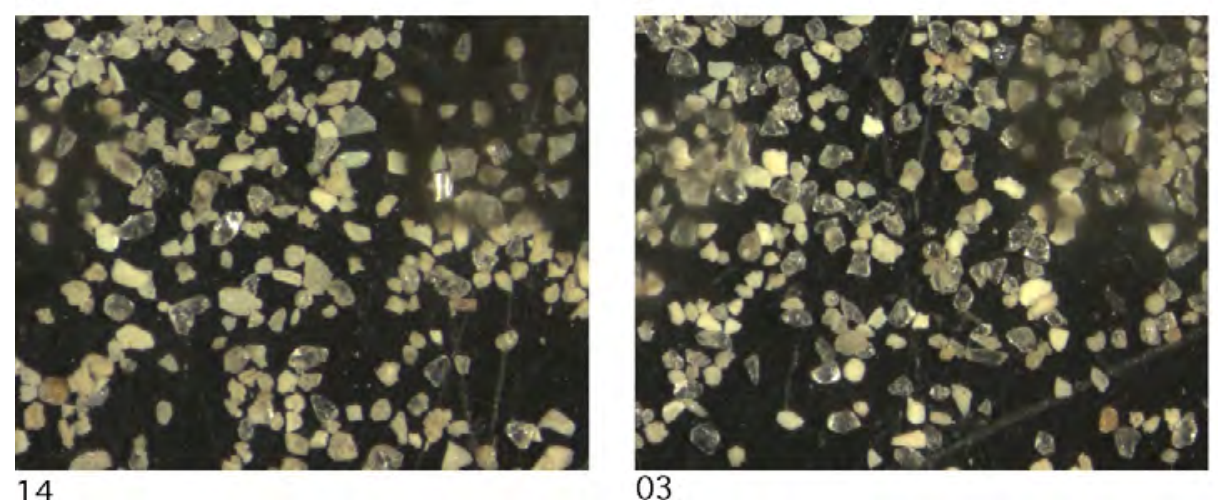

03 

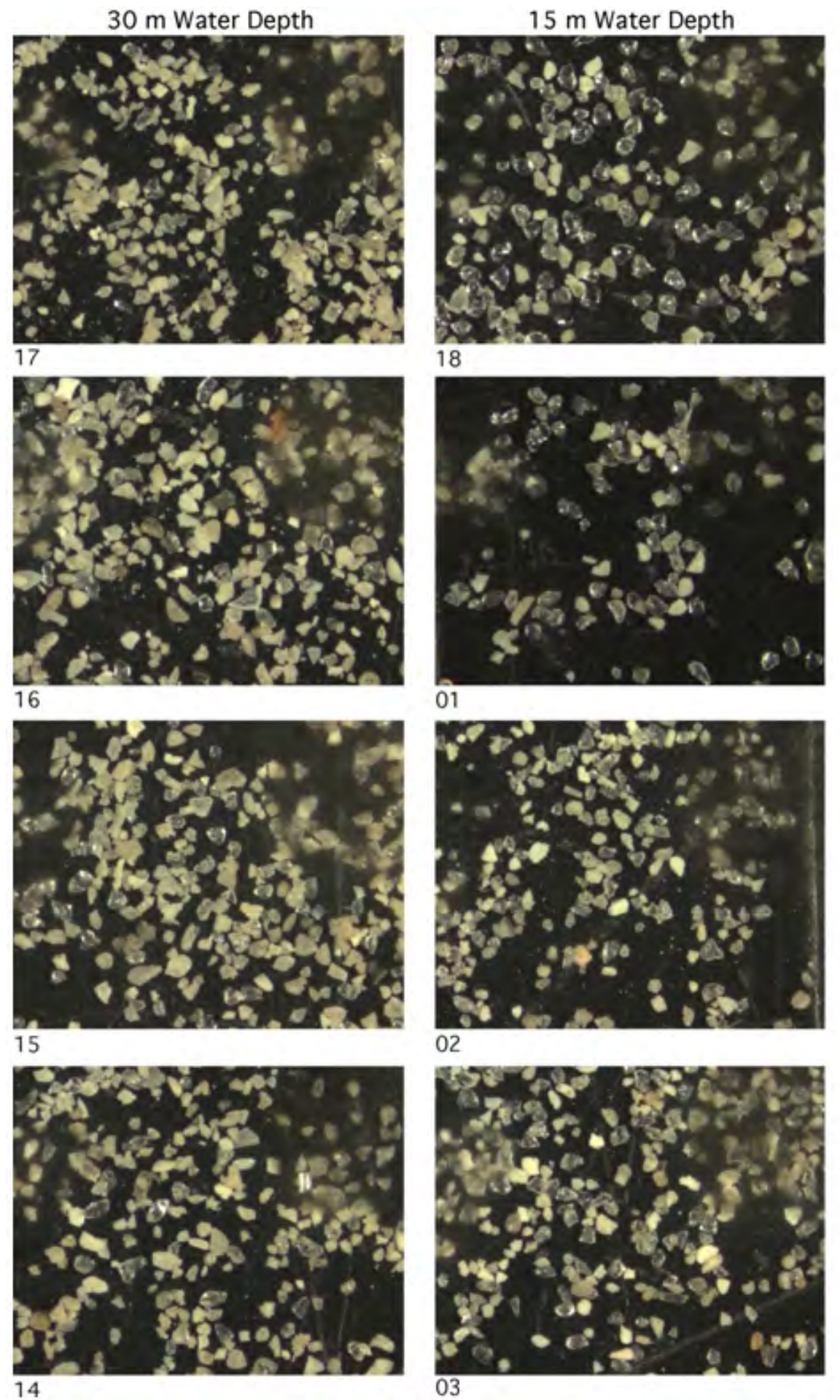

3 to 4 phi North
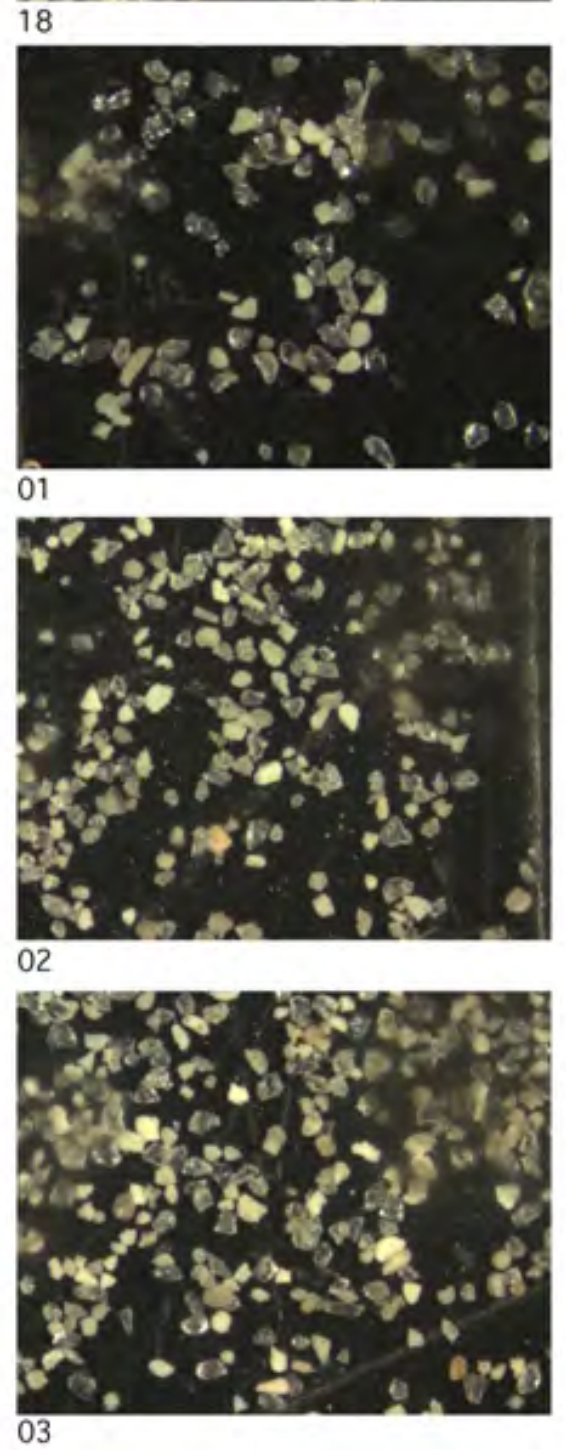

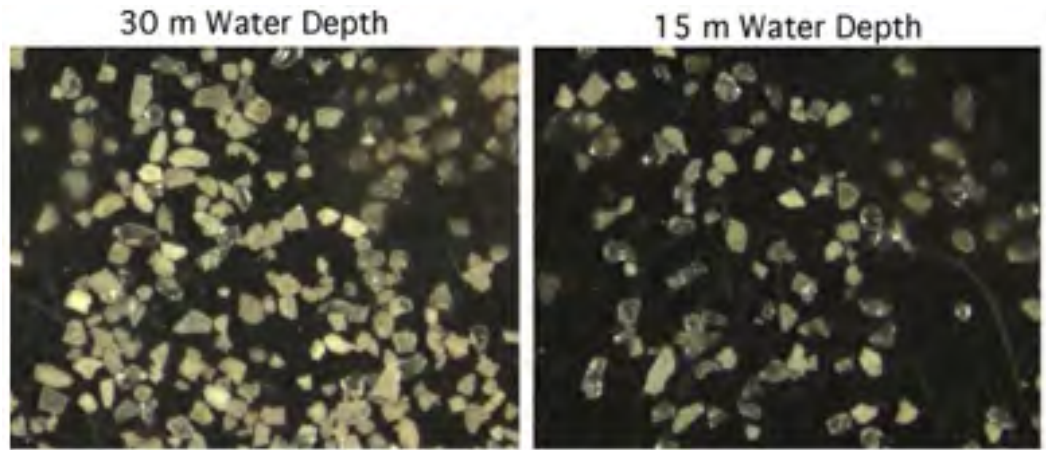

\section{3 to 4 phi South}
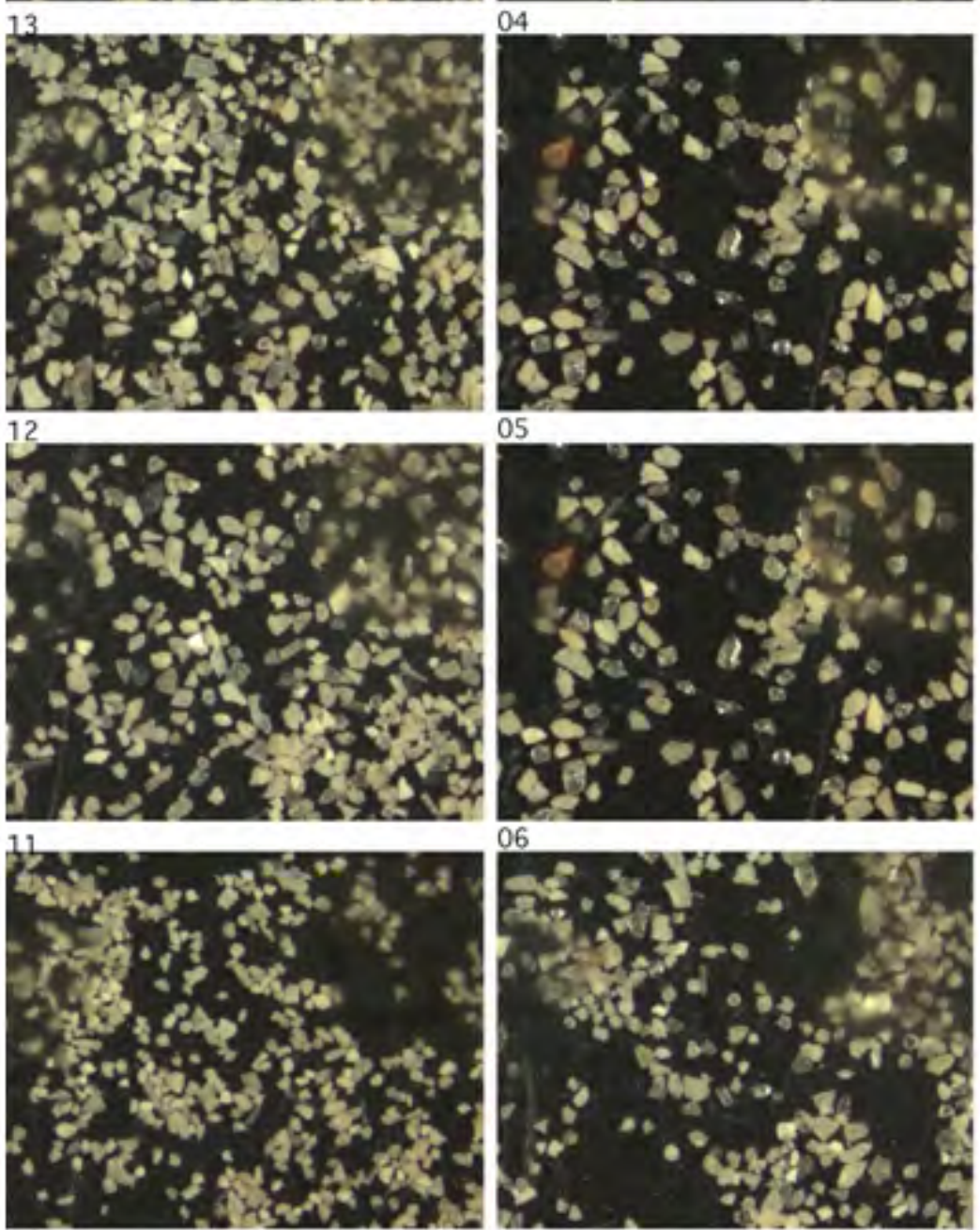

10

07
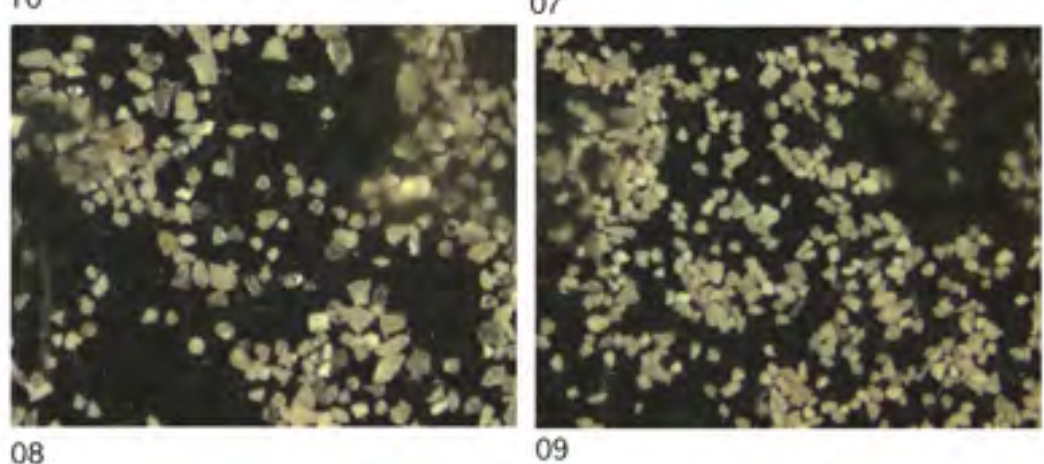

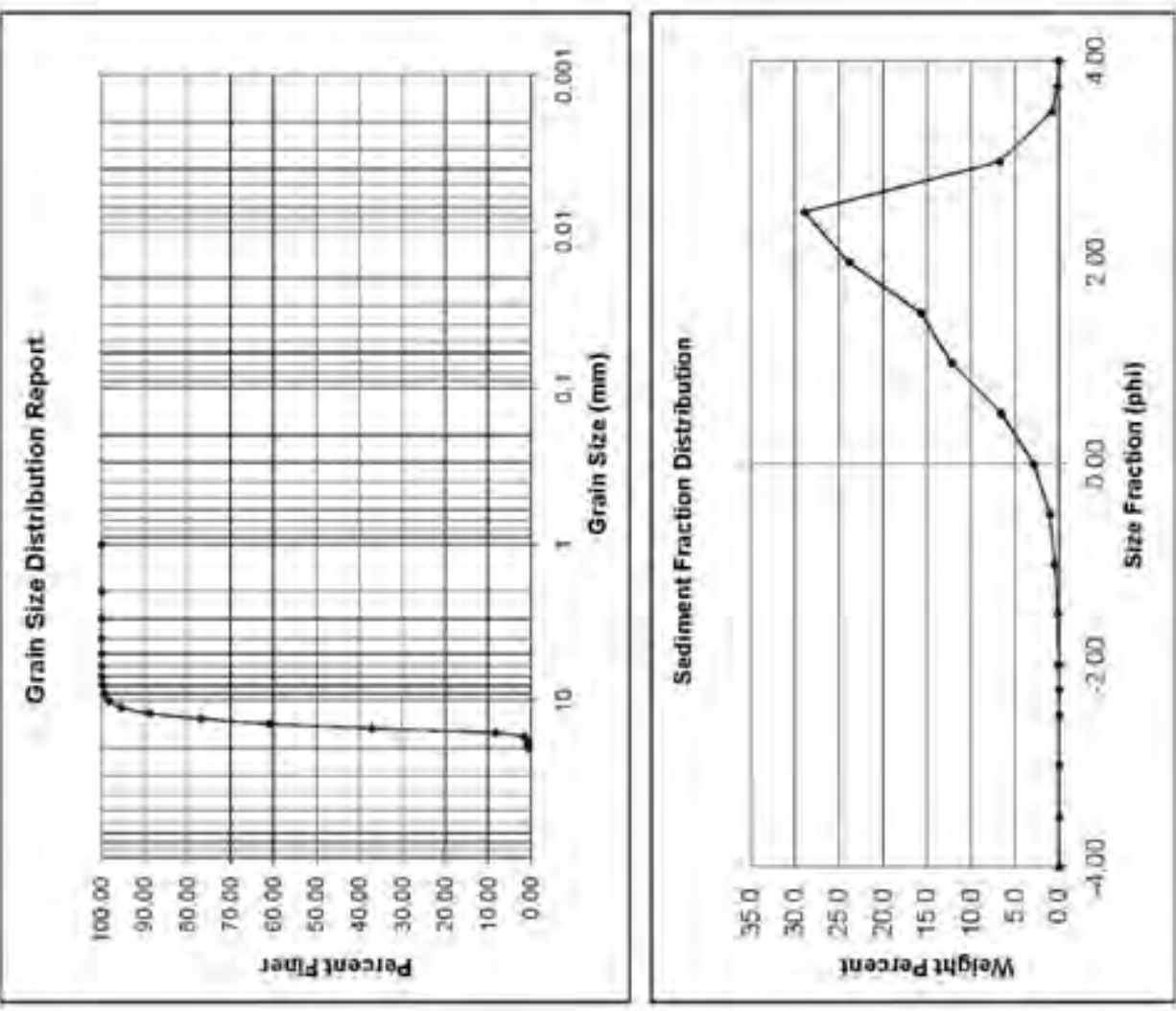

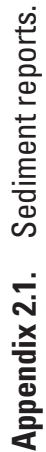
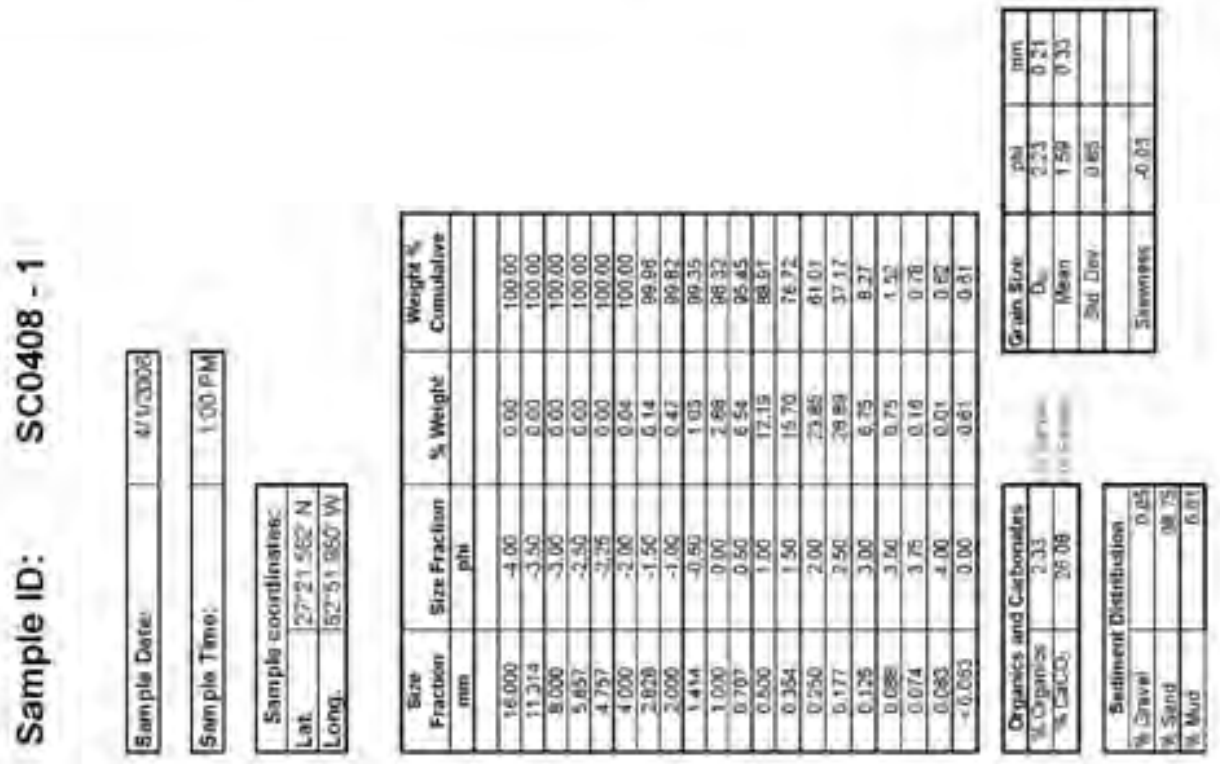

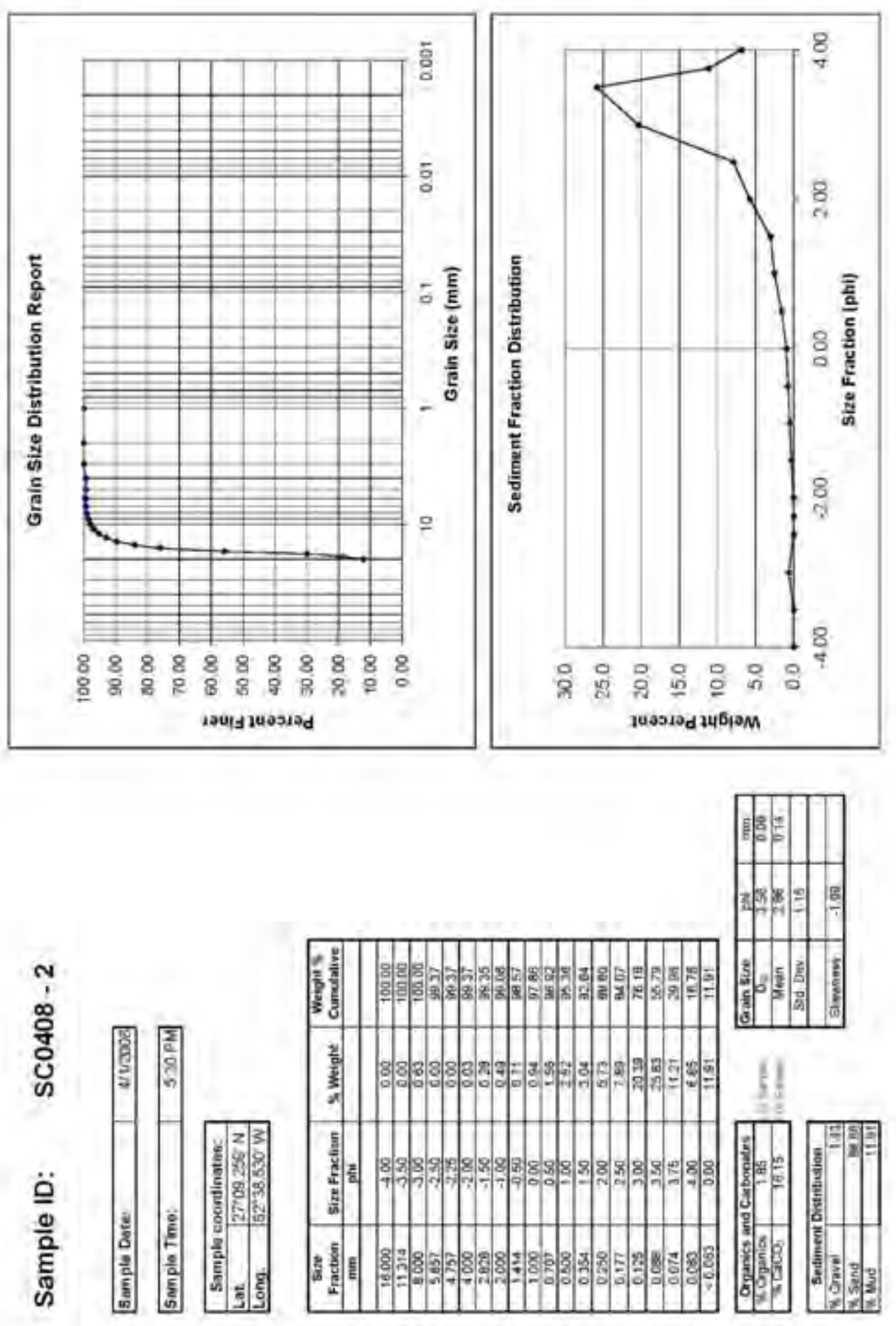

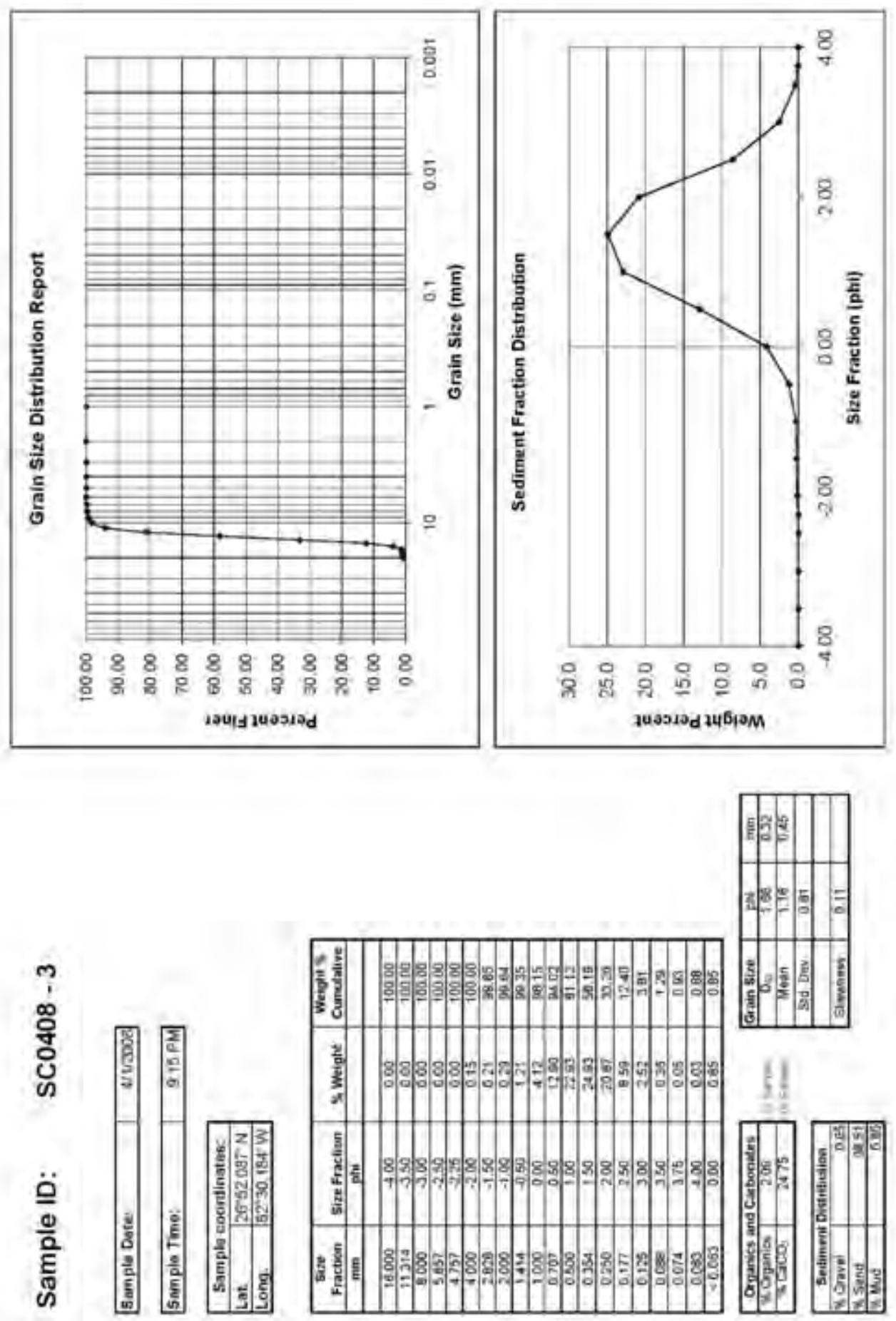

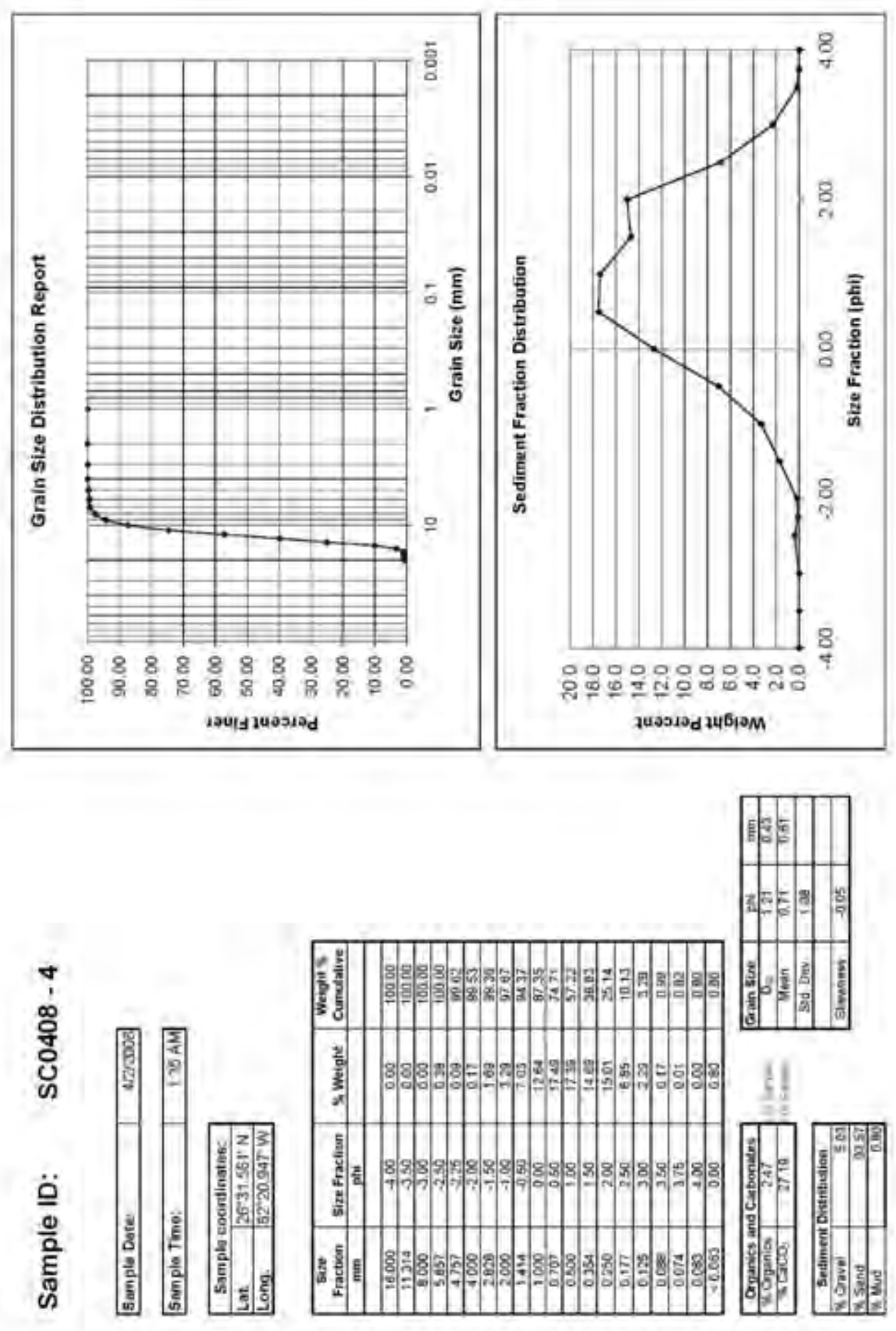

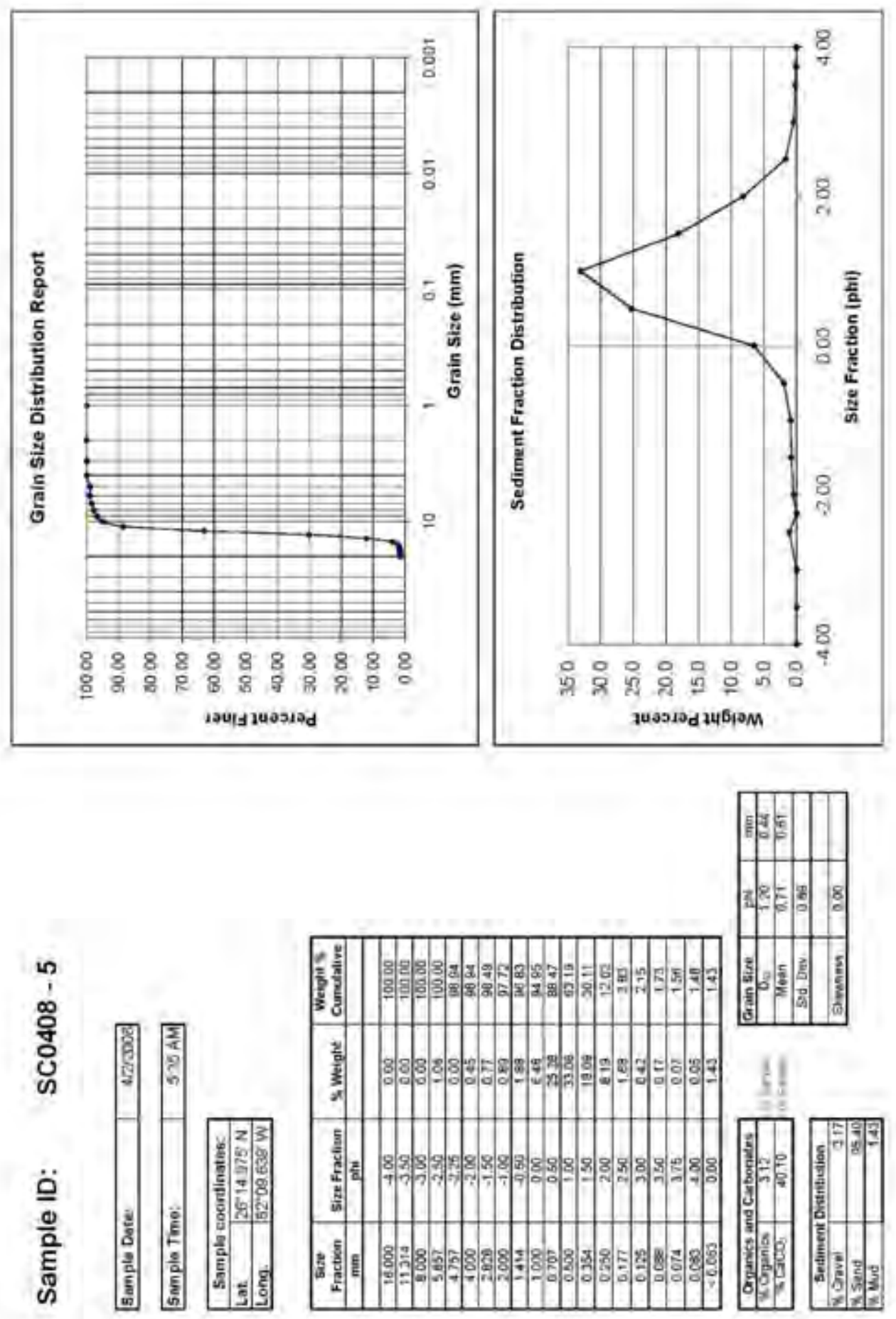

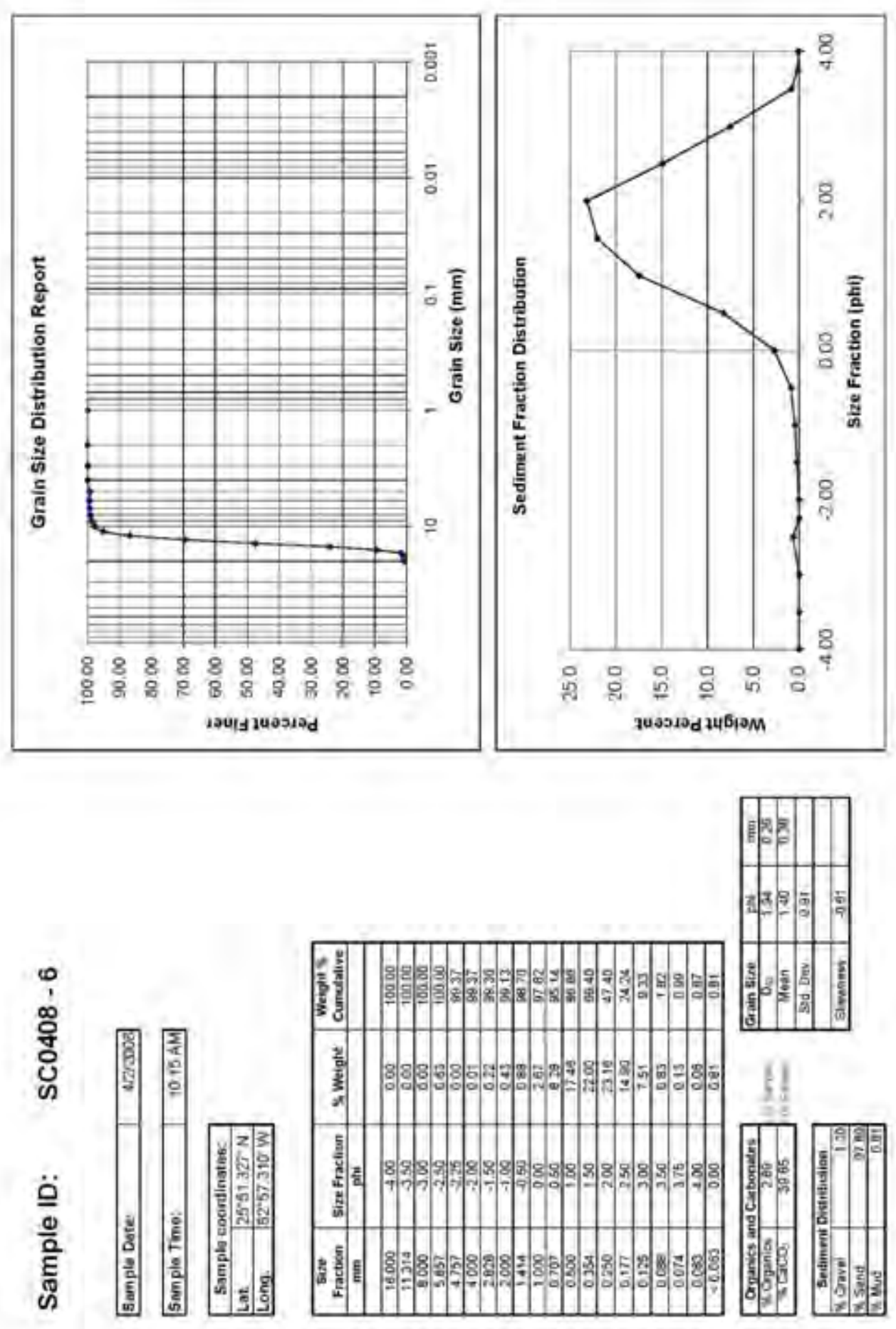

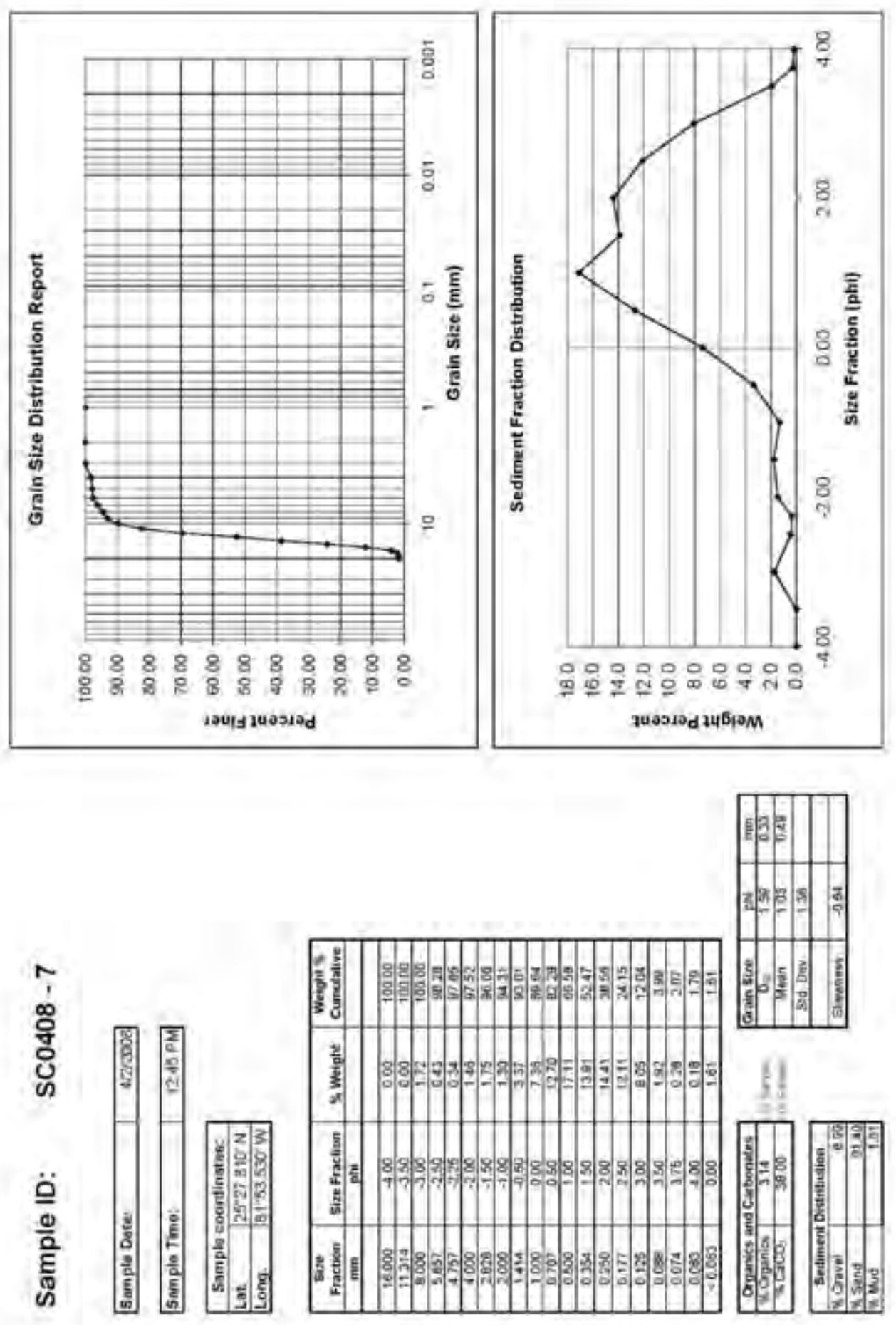

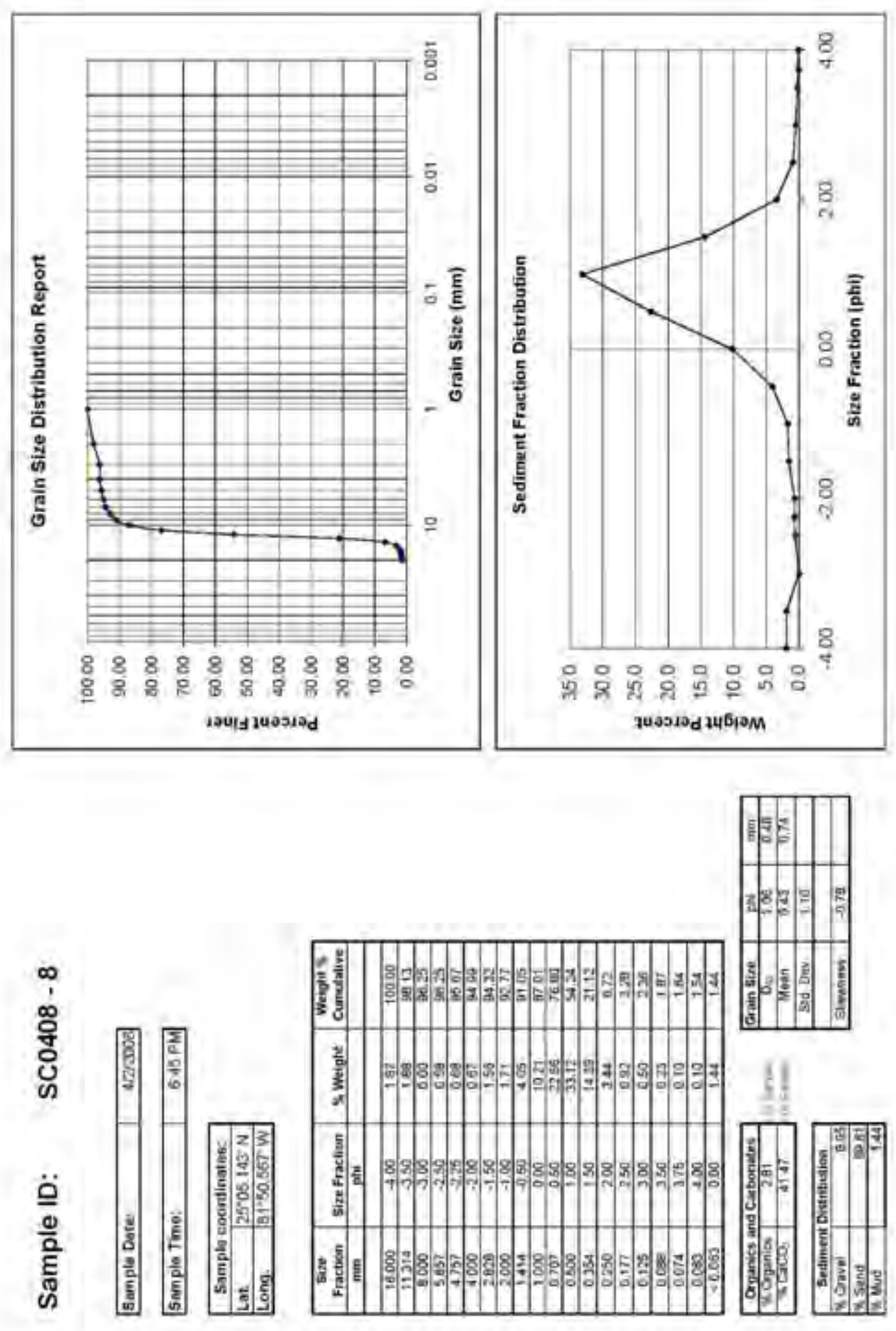

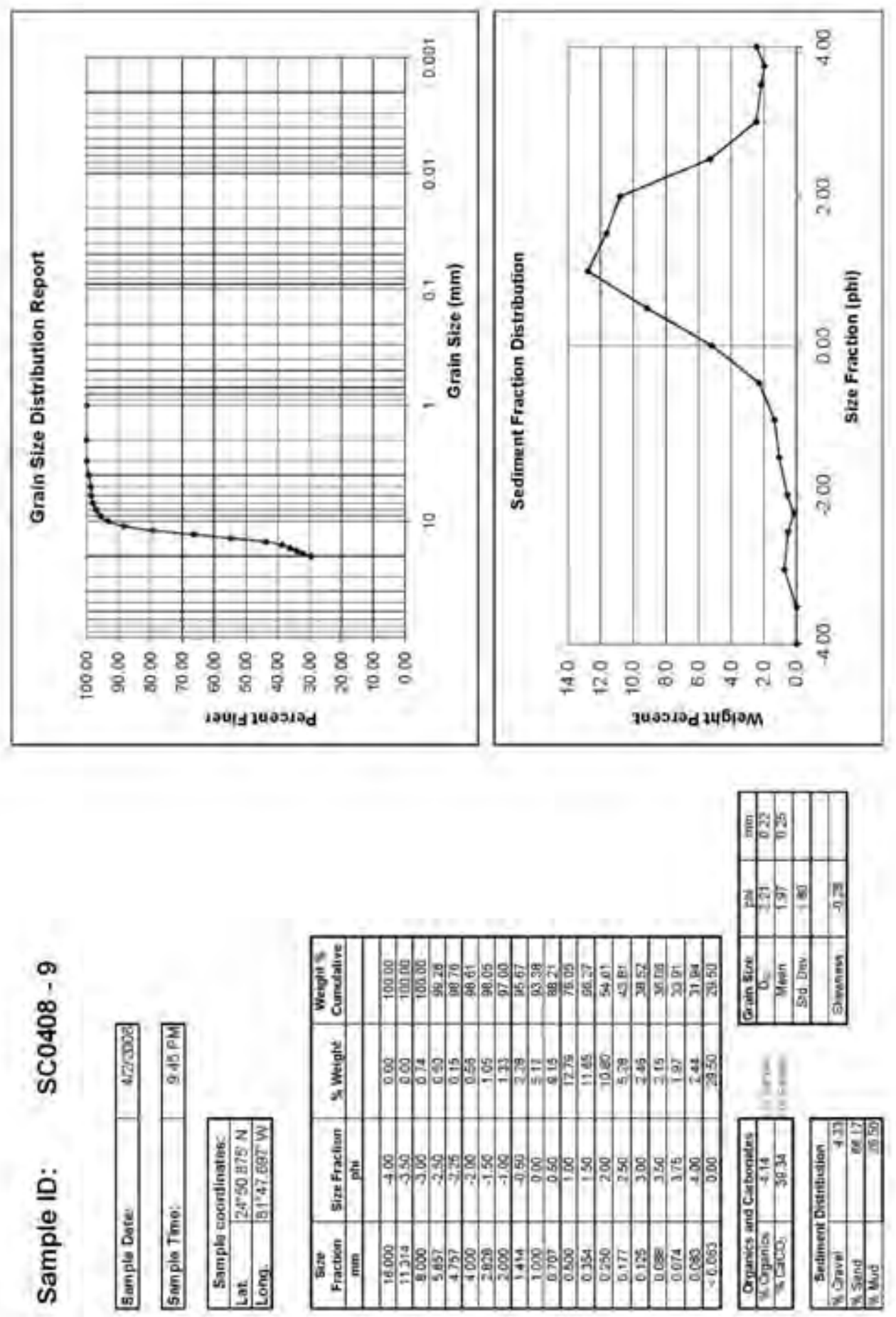

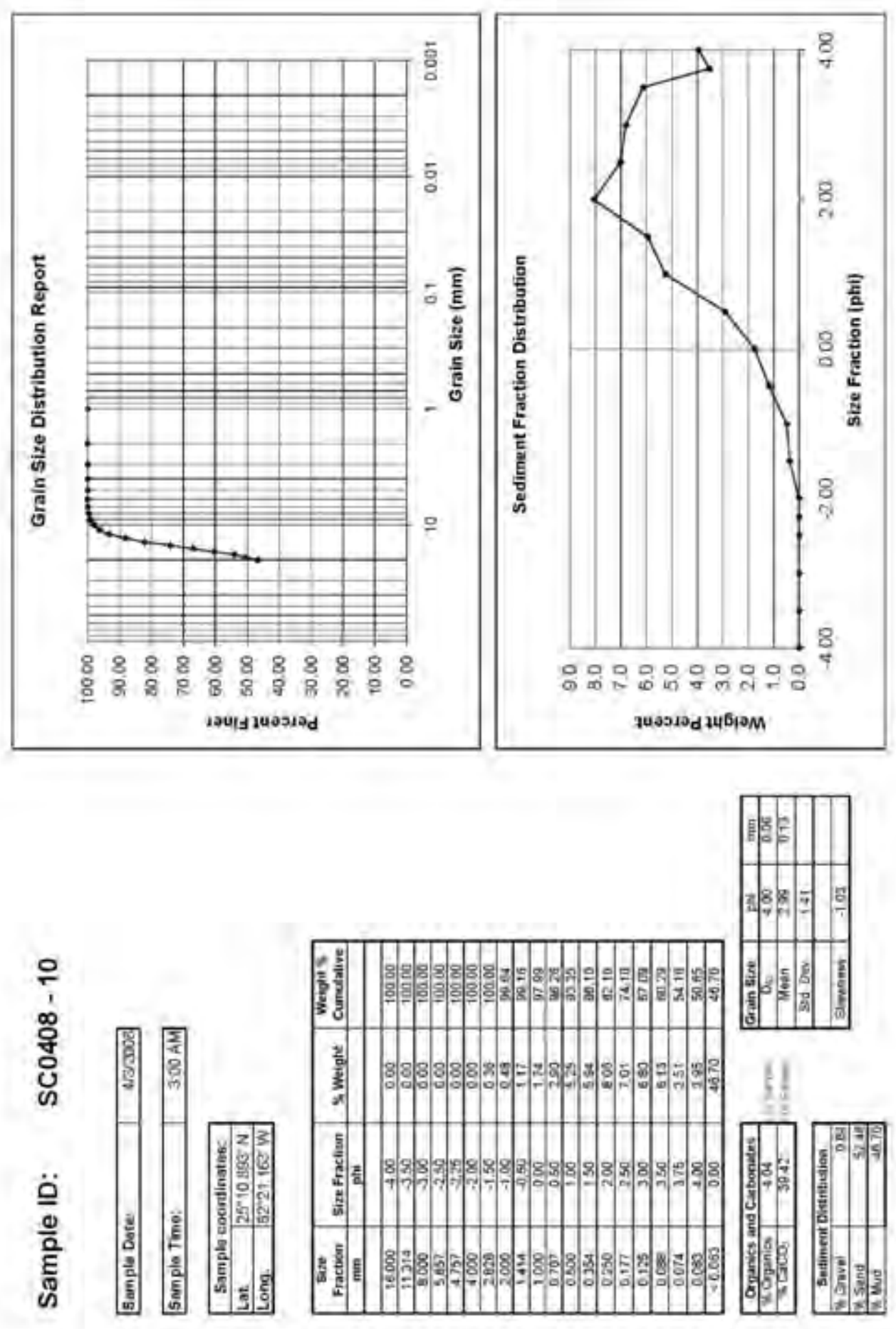

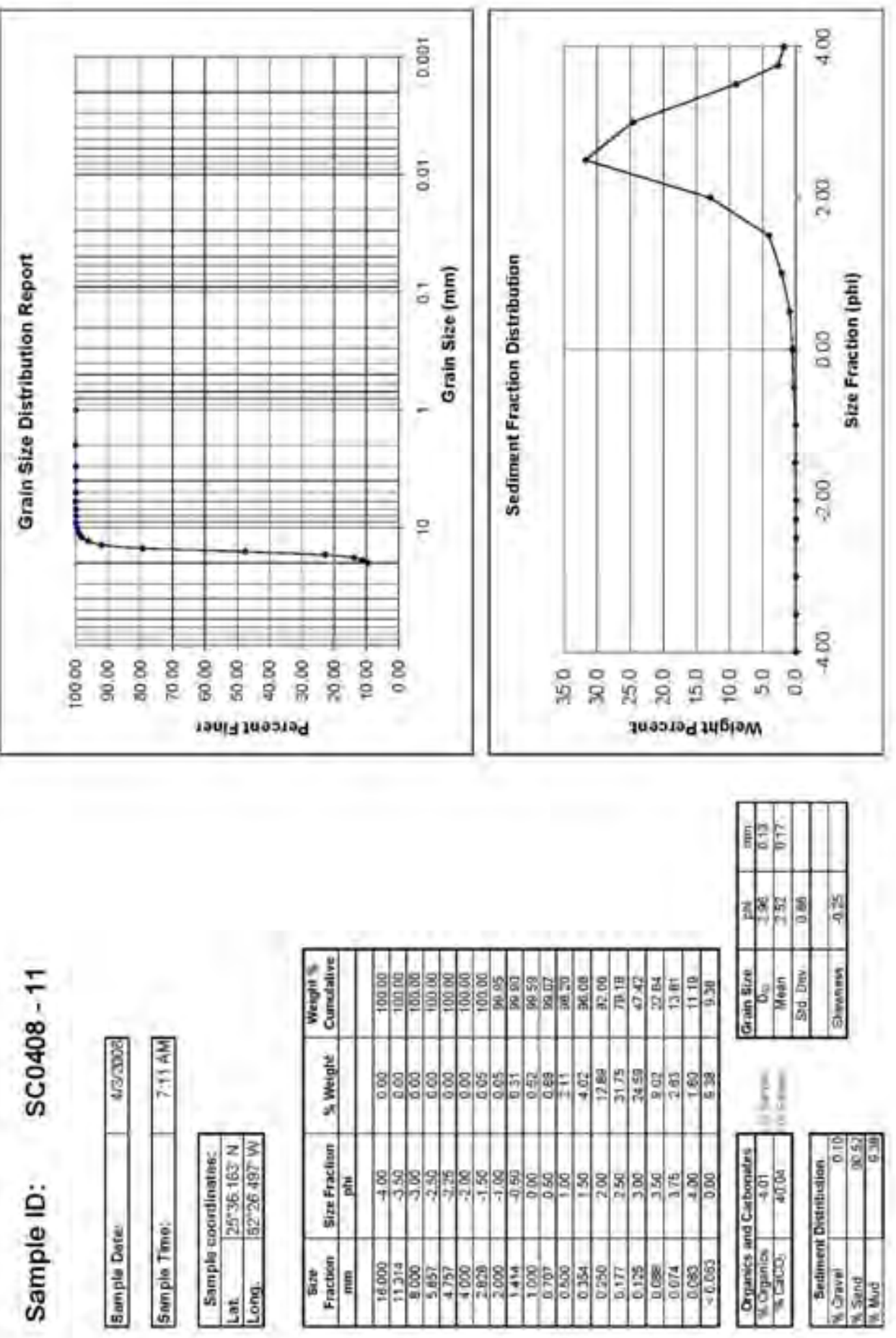

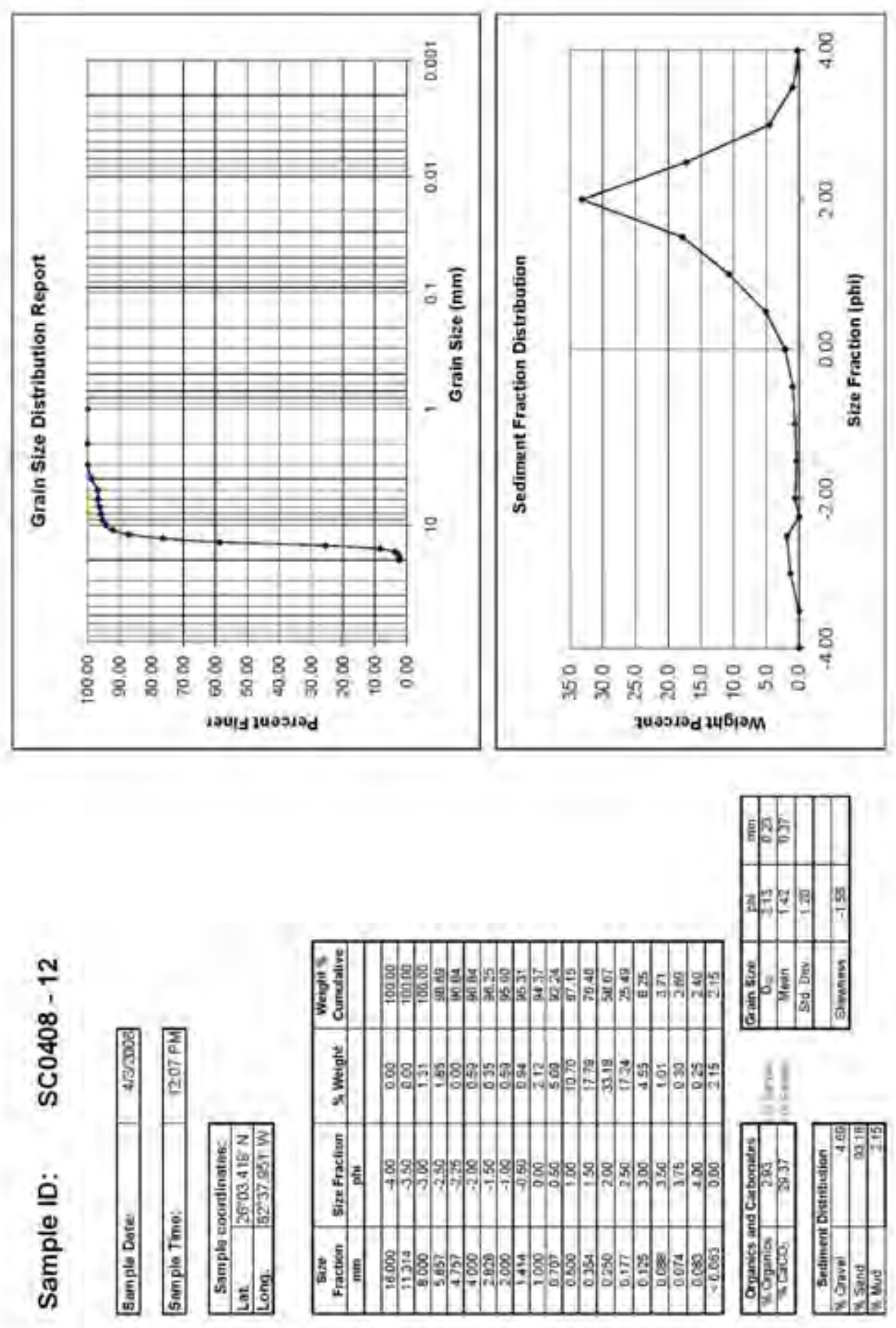

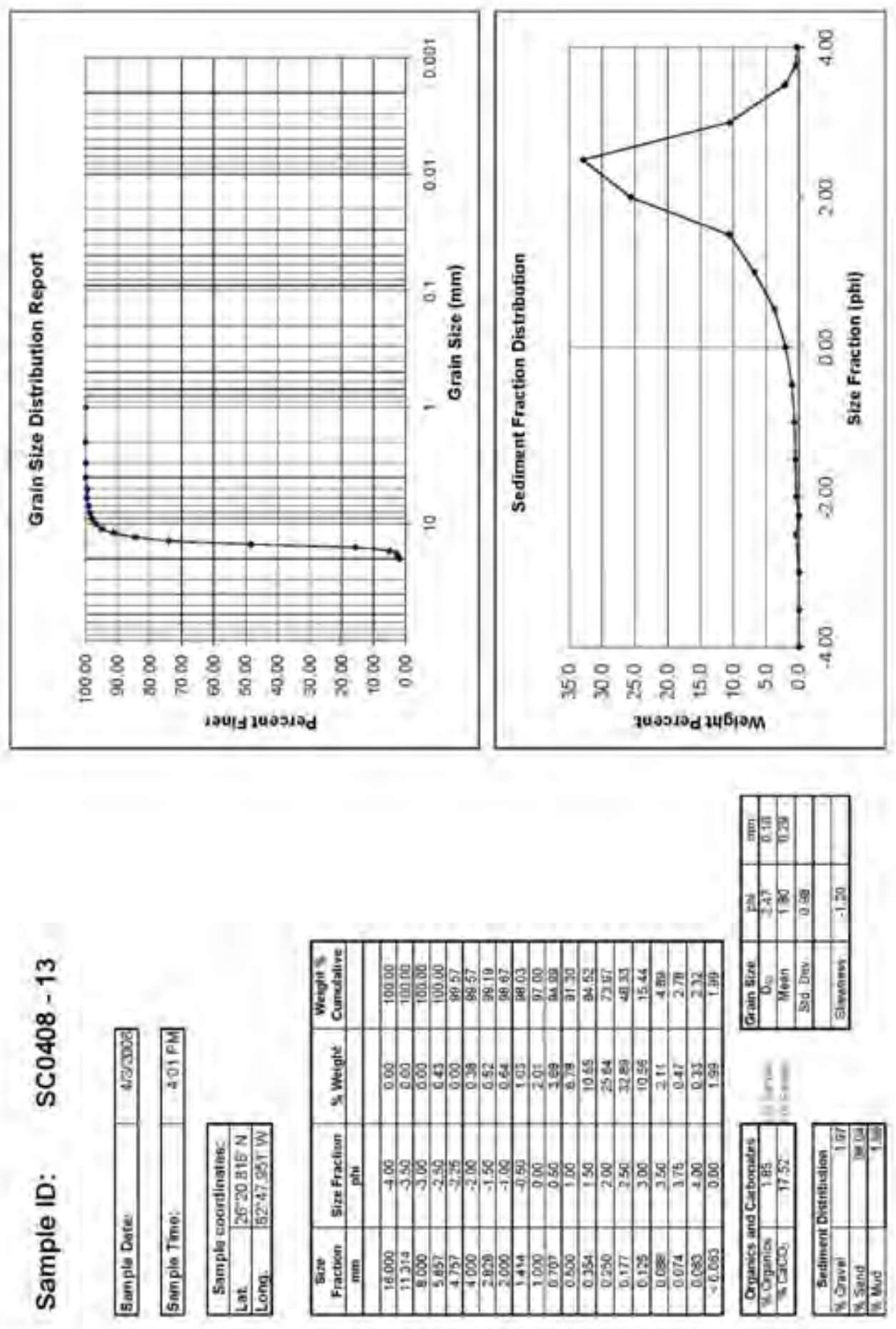

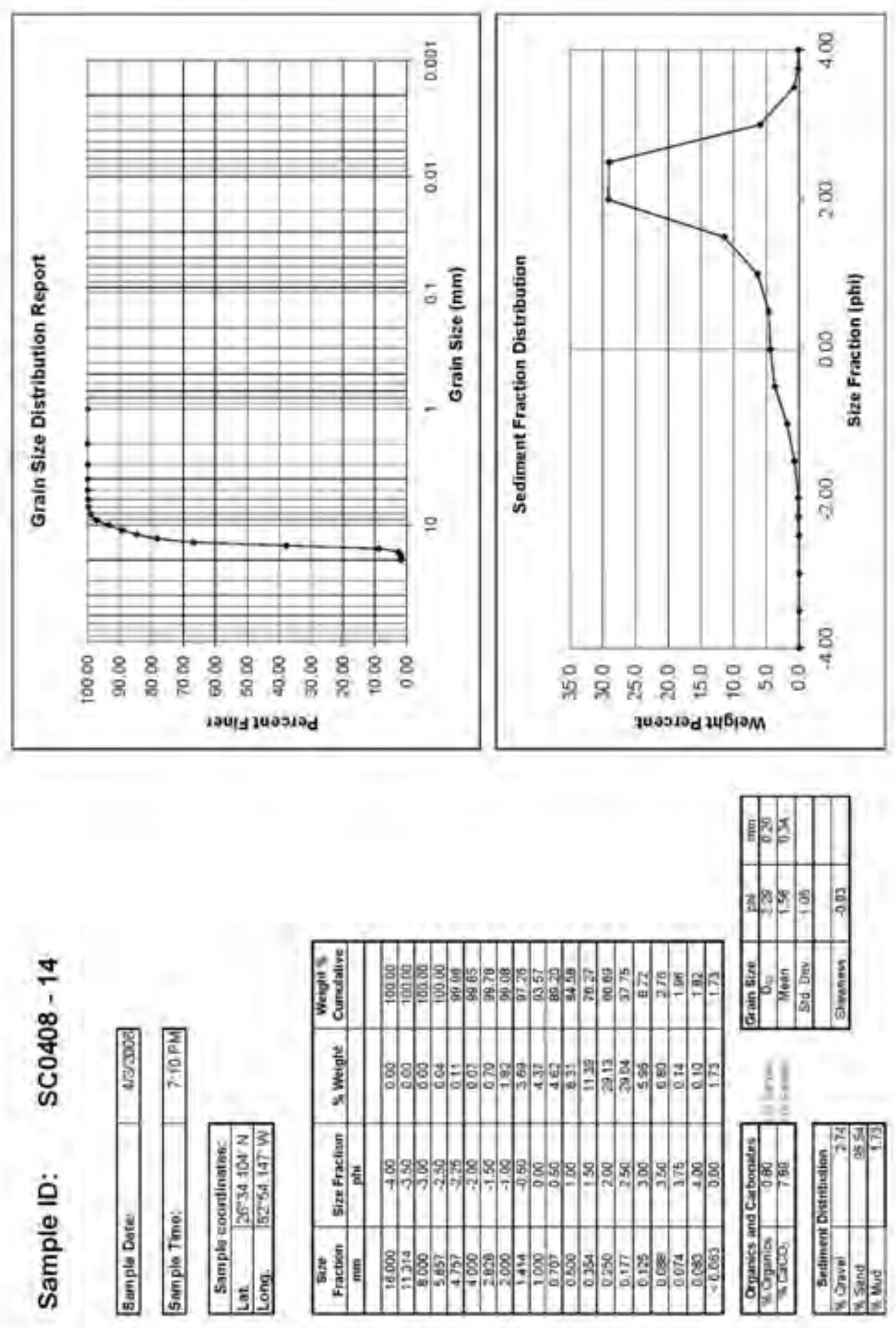

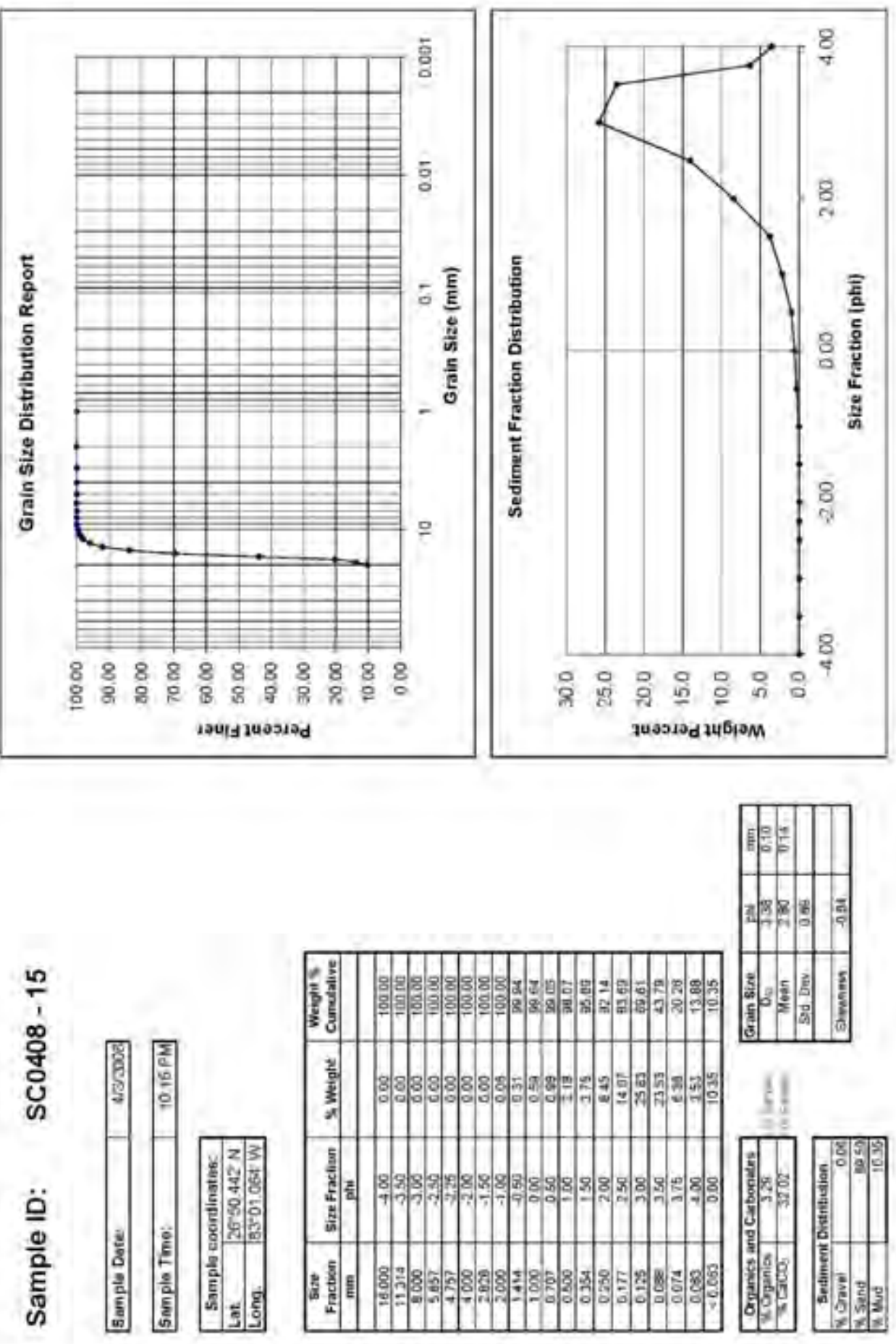

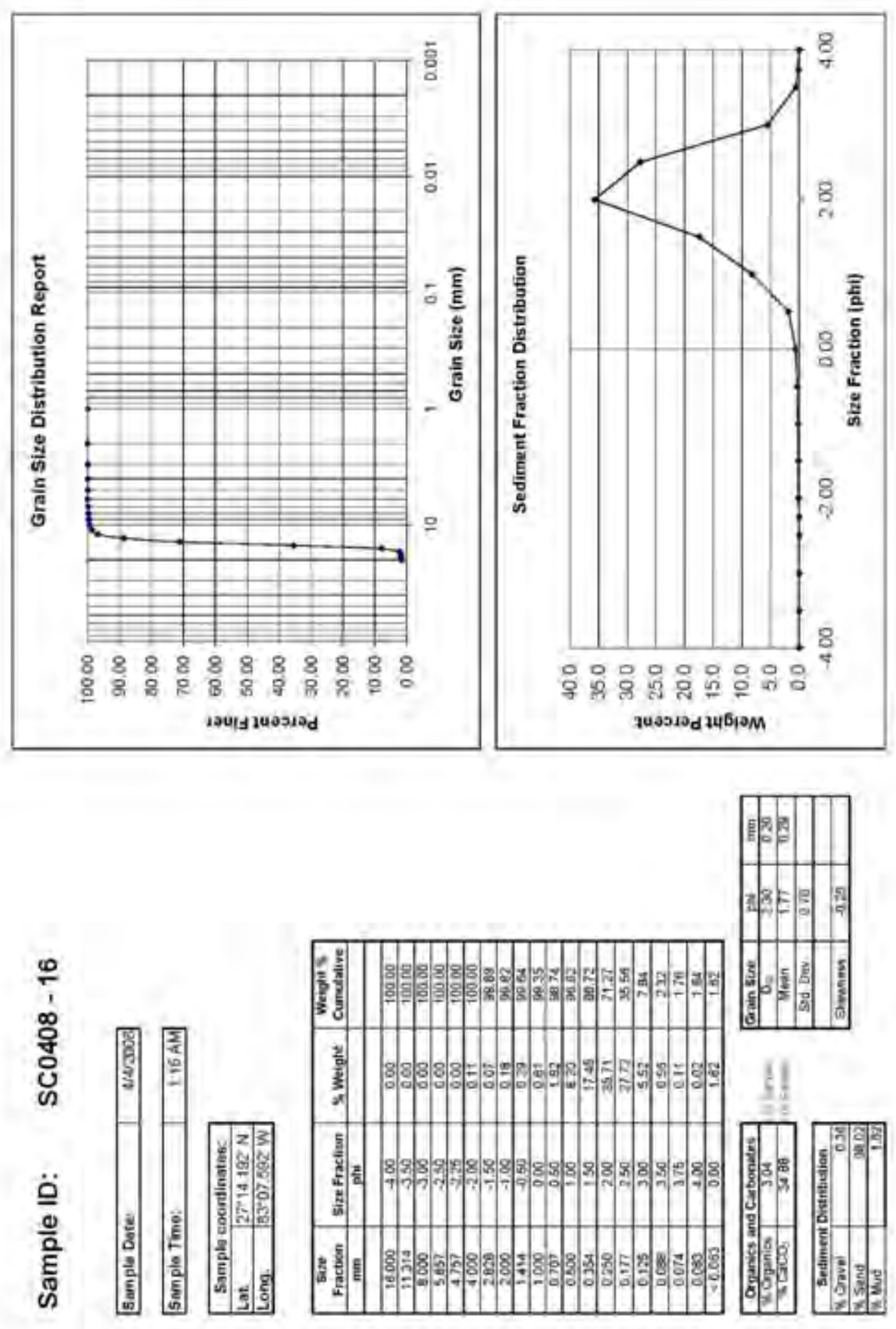

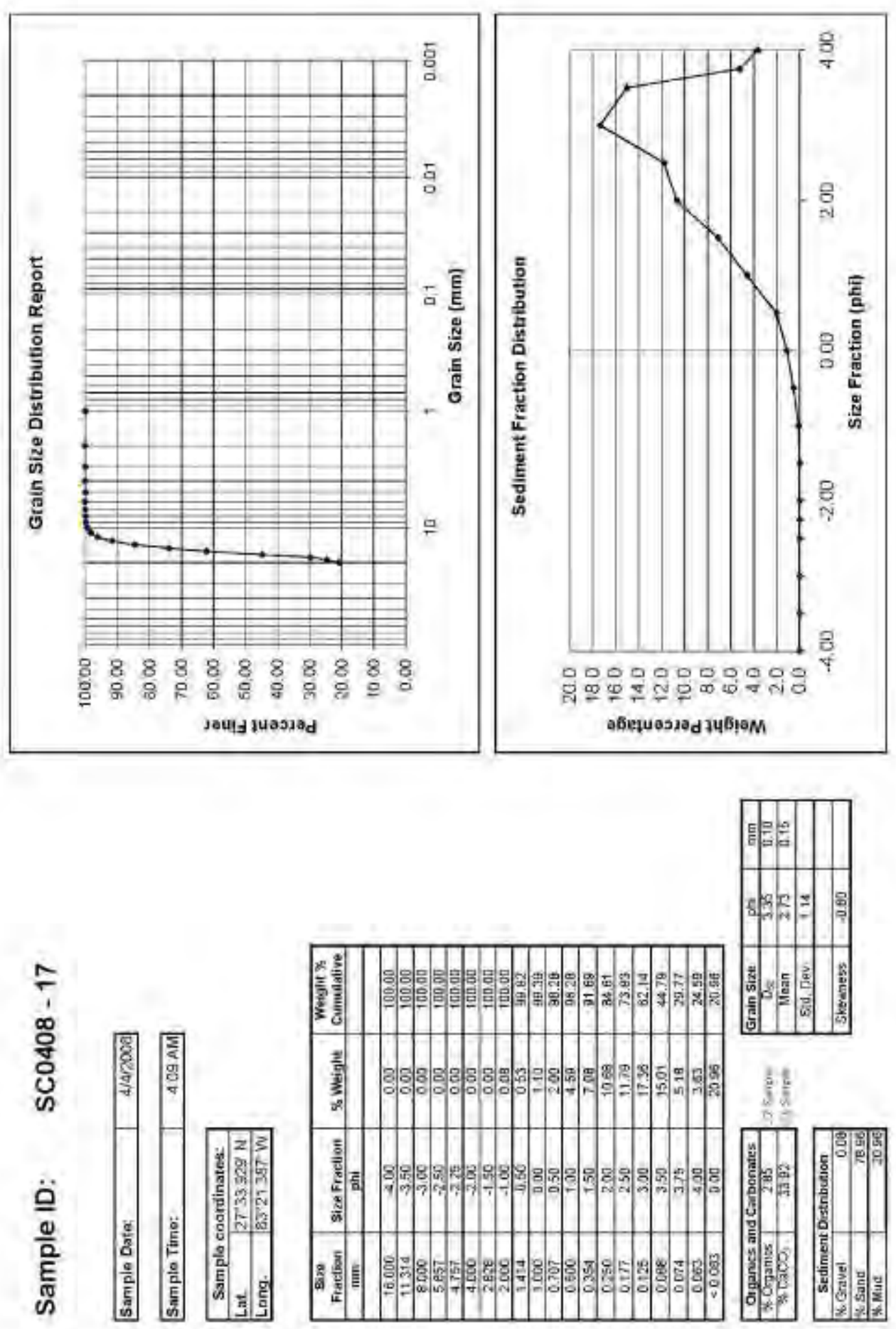

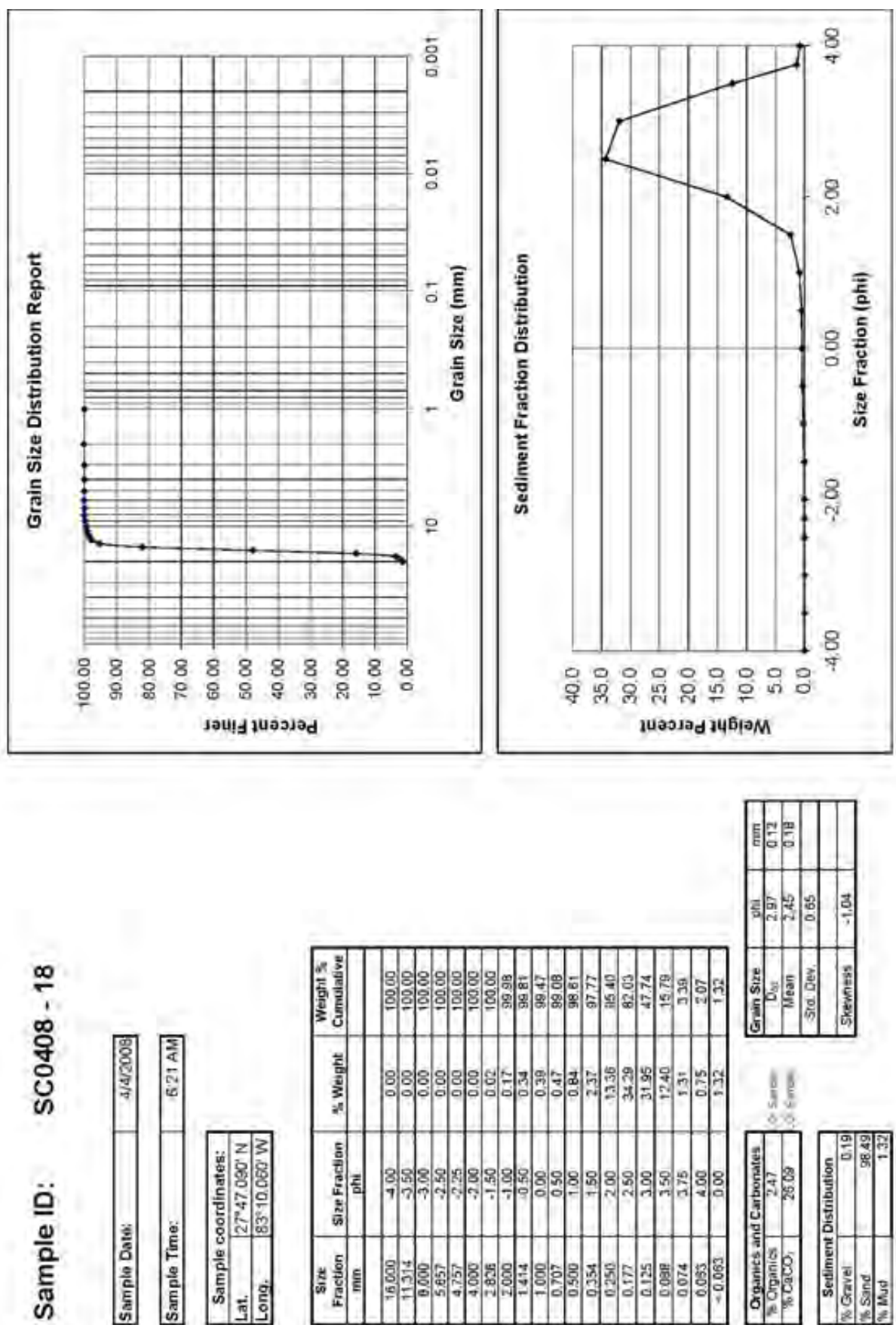
Appendix 4.1. Total foraminiferal count for the west Florida shelf.

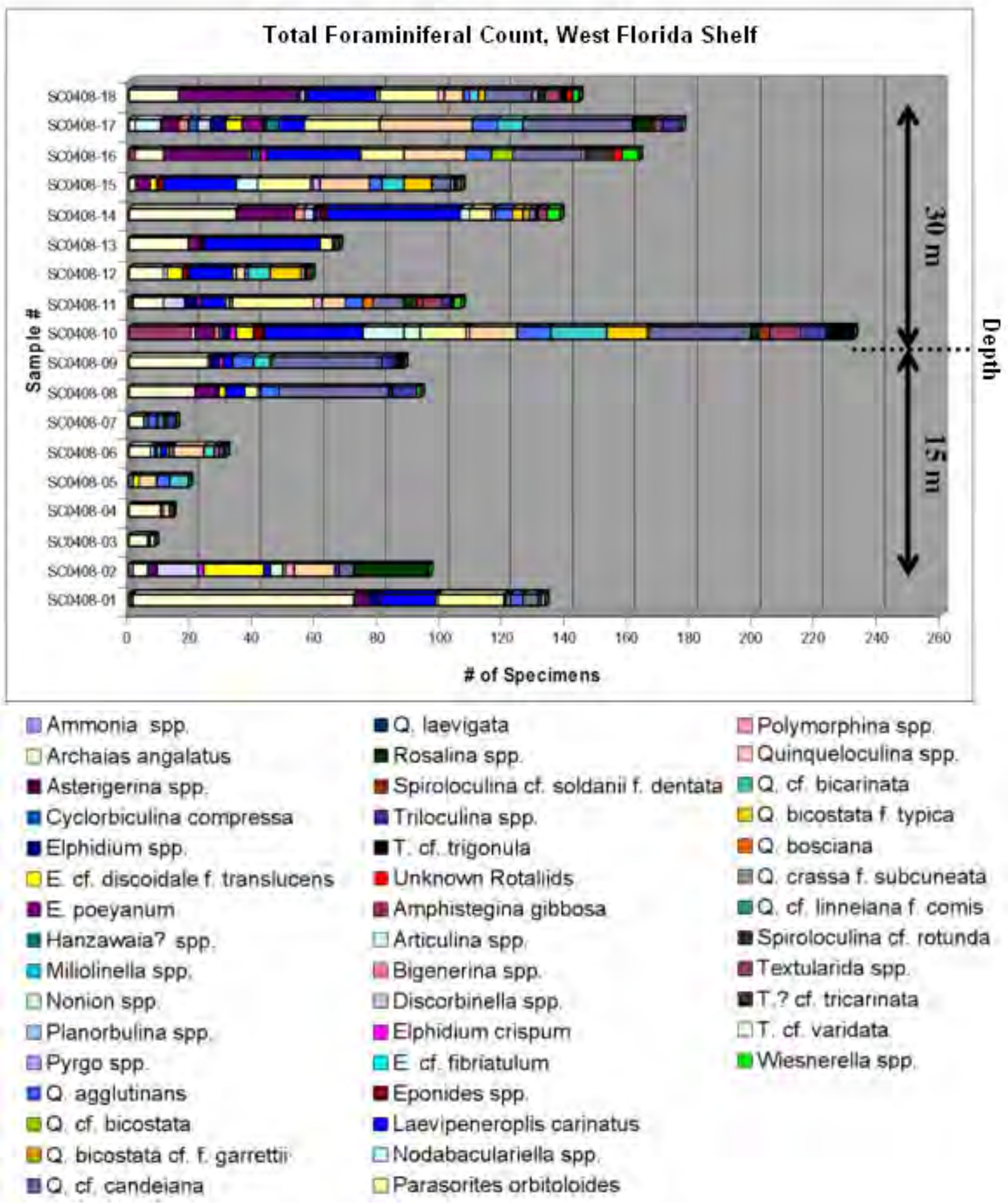




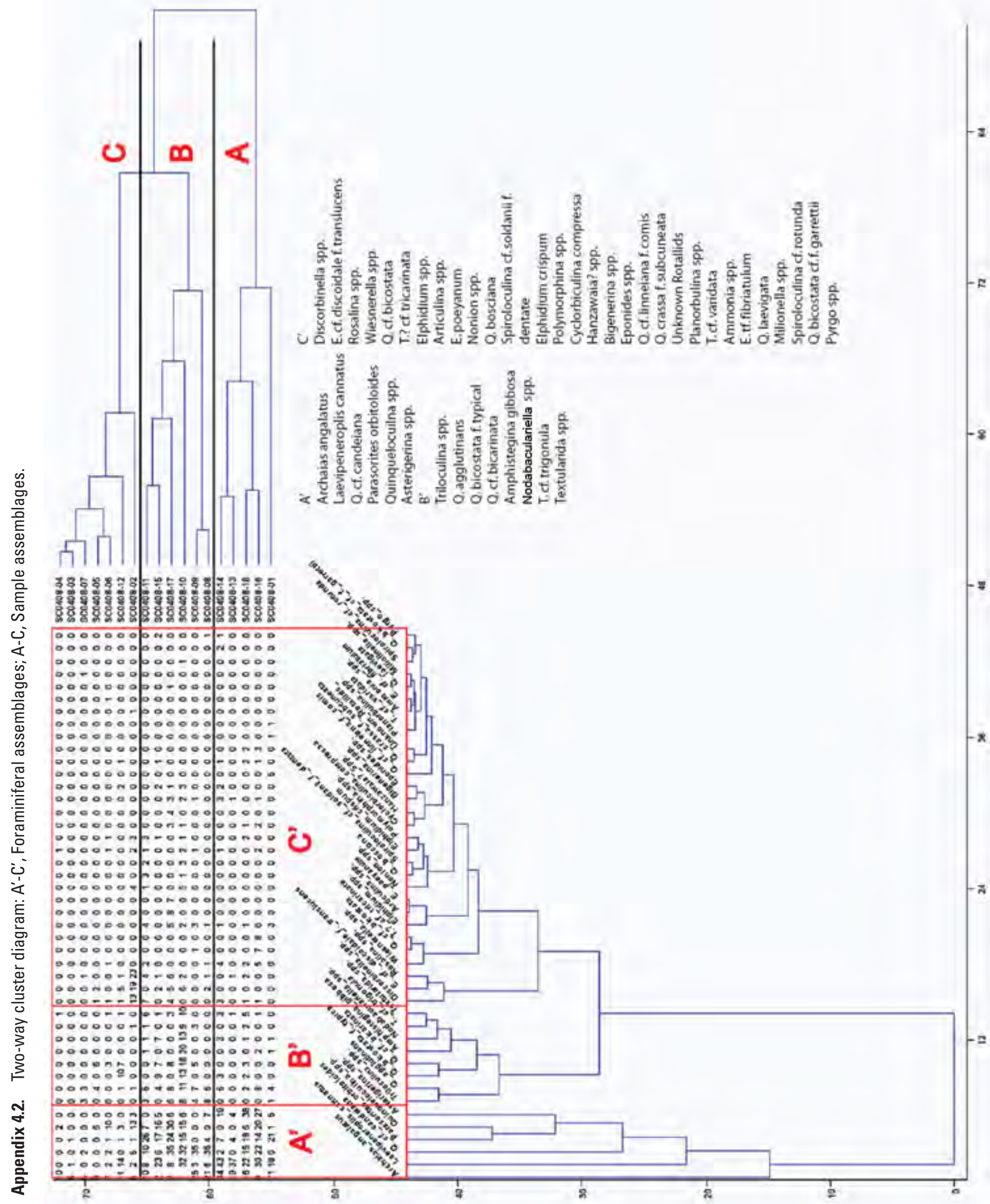


Appendix 4.3. Pearson correlation factors between foraminifers and physical parameters.

[Yellow represents a positive correlation; red represents a negative correlation. The sediment size, D50, is defined as the grain diameter at which 50 percent of the sediment sample is finer than]

$\% \cos$ TOC \% Mud \% Sand Dso

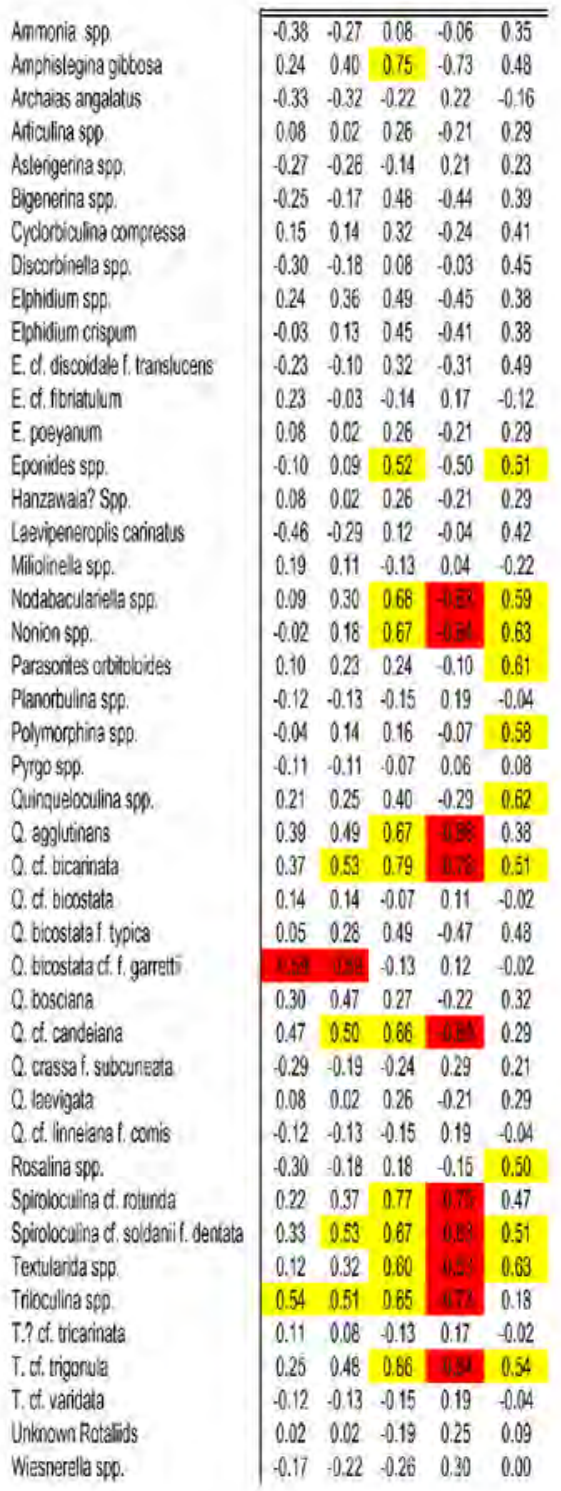


Appendix 5.1. PAR data modeled from the scalar irradiance spectroradiometer.

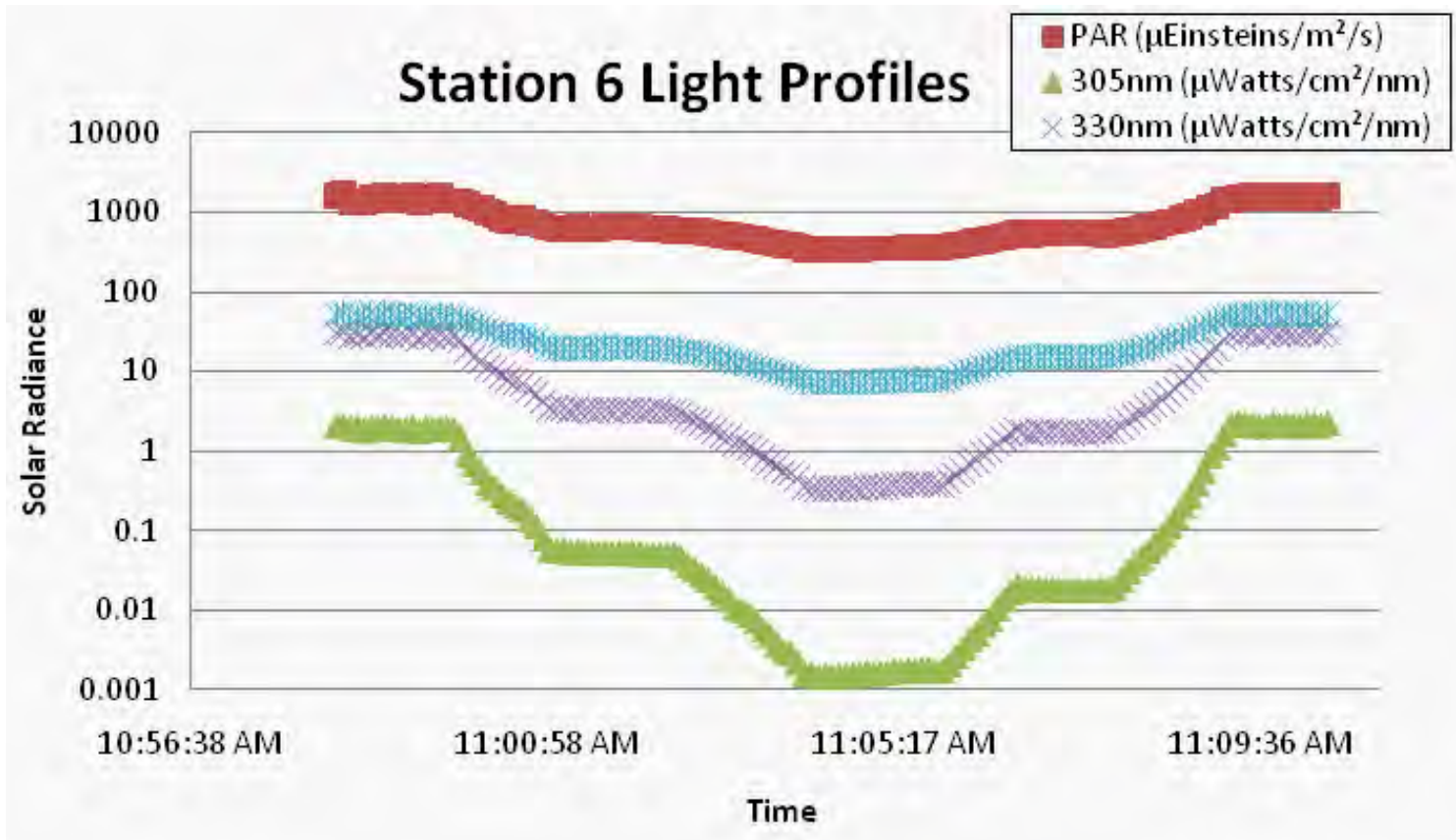

Figure 5.1.1: Solar Radiance versus Time at Station 6 for PAR, 350nm, and 330nm.

\section{Station SC040208-06: UV to PAR}

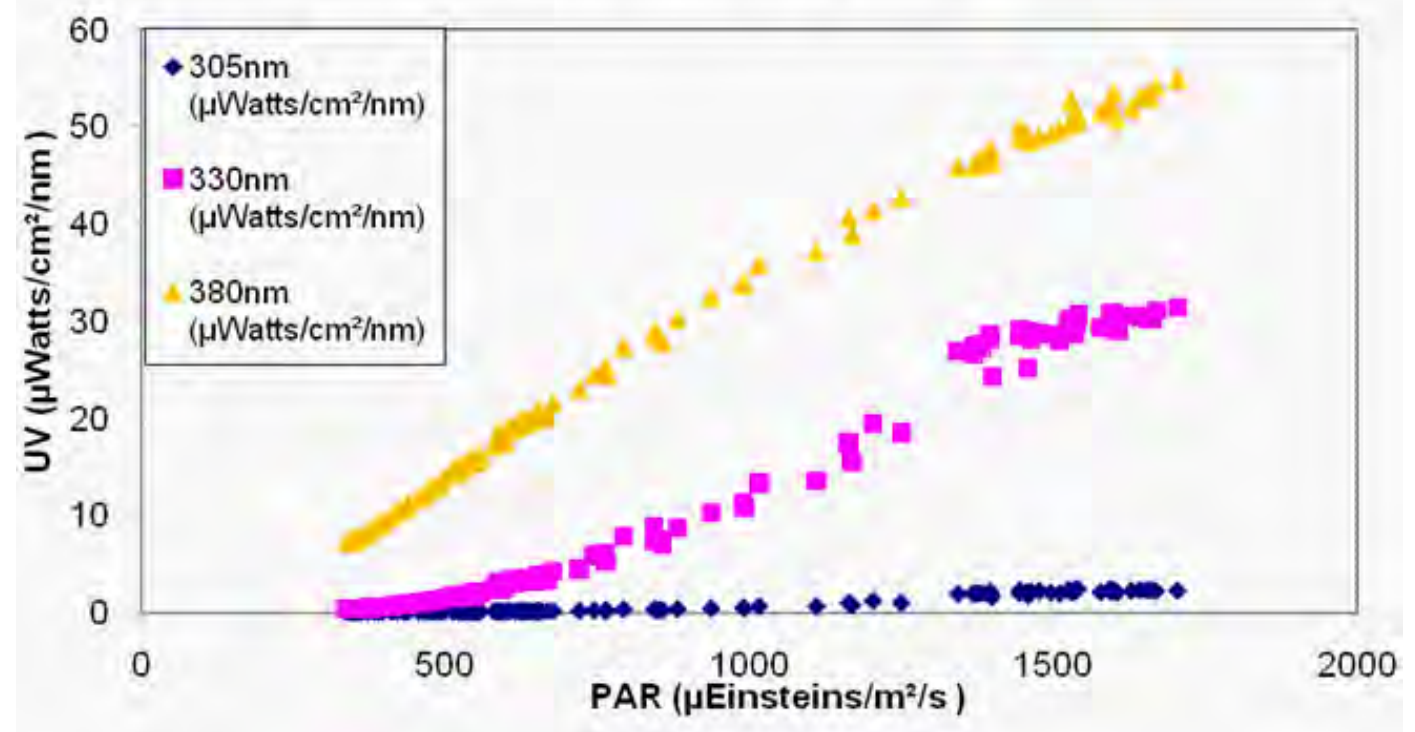

Figure 5.1.2: $\quad$ Ultraviolet (UV) Radiation versus Photosynthetically Available Radiation (PAR) from Station 6. 


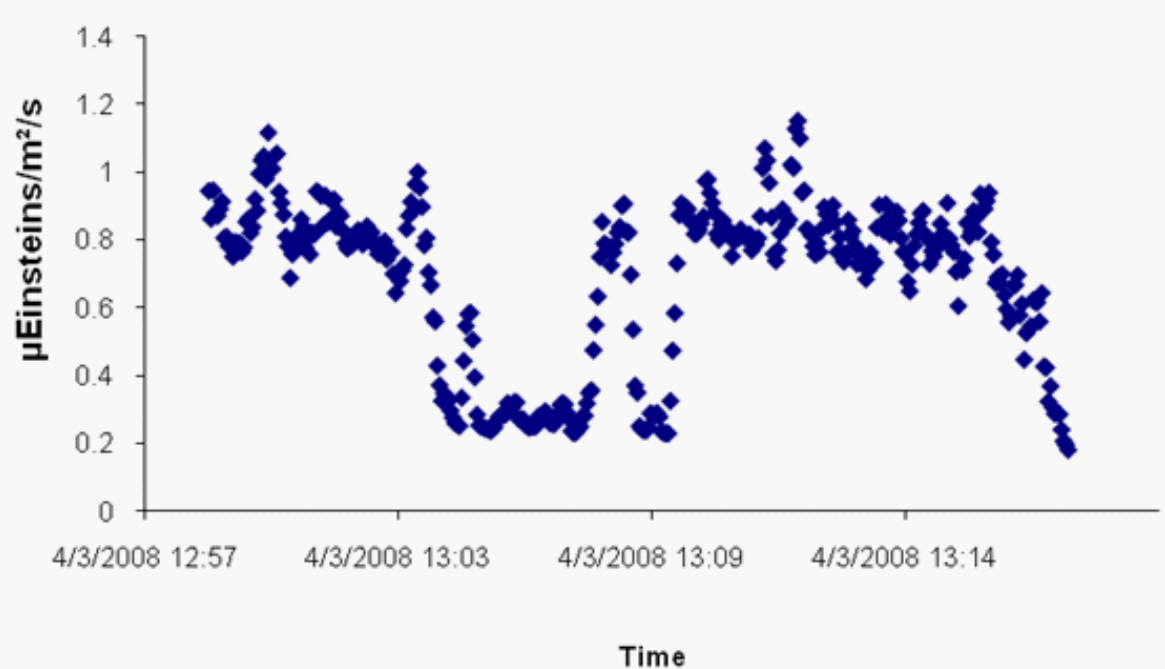

Figure 5.1.3: Variation of PAR at Station 12 over 20 minutes.

\section{PAR Station 1}

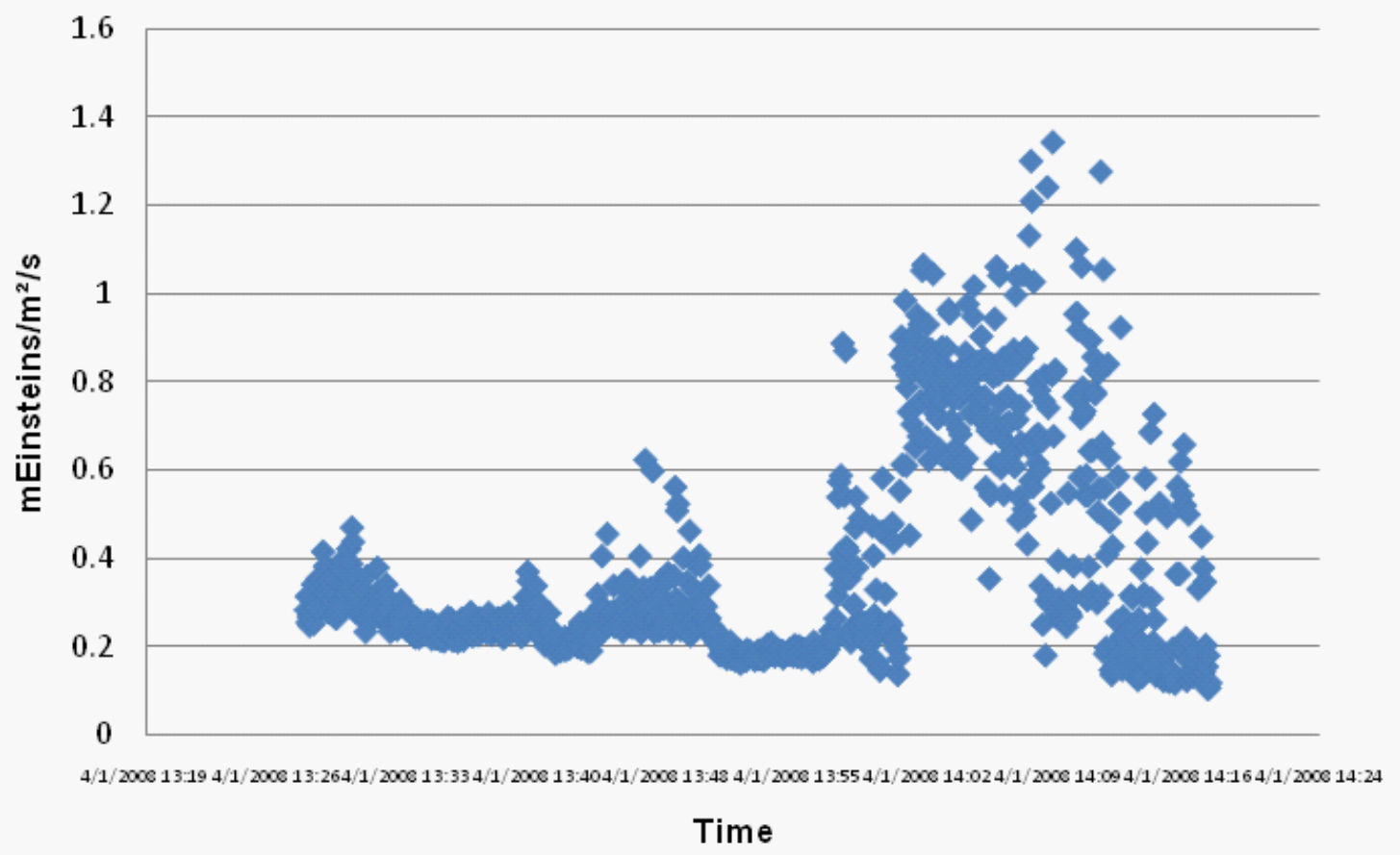

Figure 5.1.4: Variation of Photosynthetically Active Radiation (PAR) at Station 1 over one hour. 


\section{PAR Station 6}

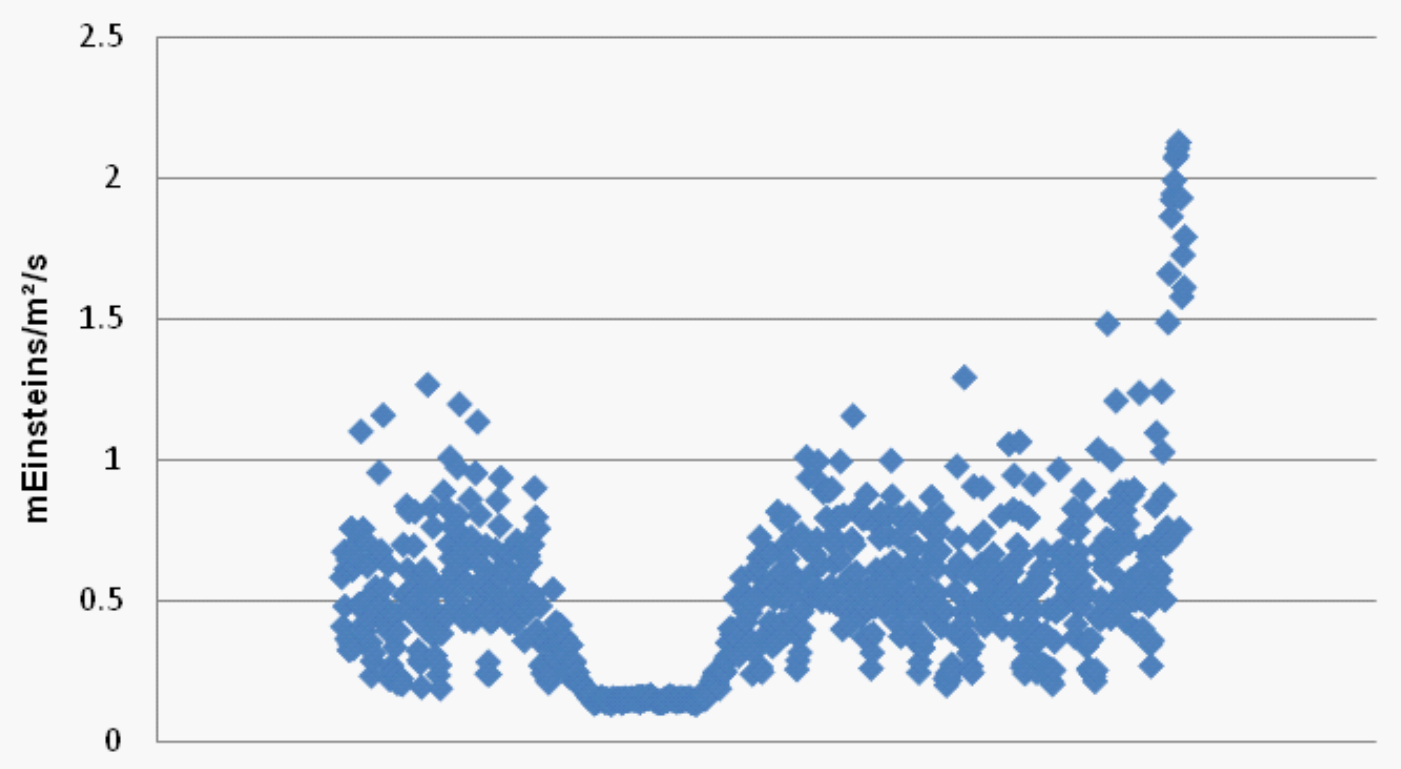

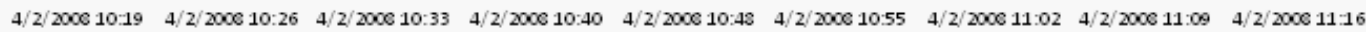

Time

Figure 5.1.5: Variation of Photosynthetically Active Radiation (PAR) at Station 6 over one hour.

\section{PAR Station 7}

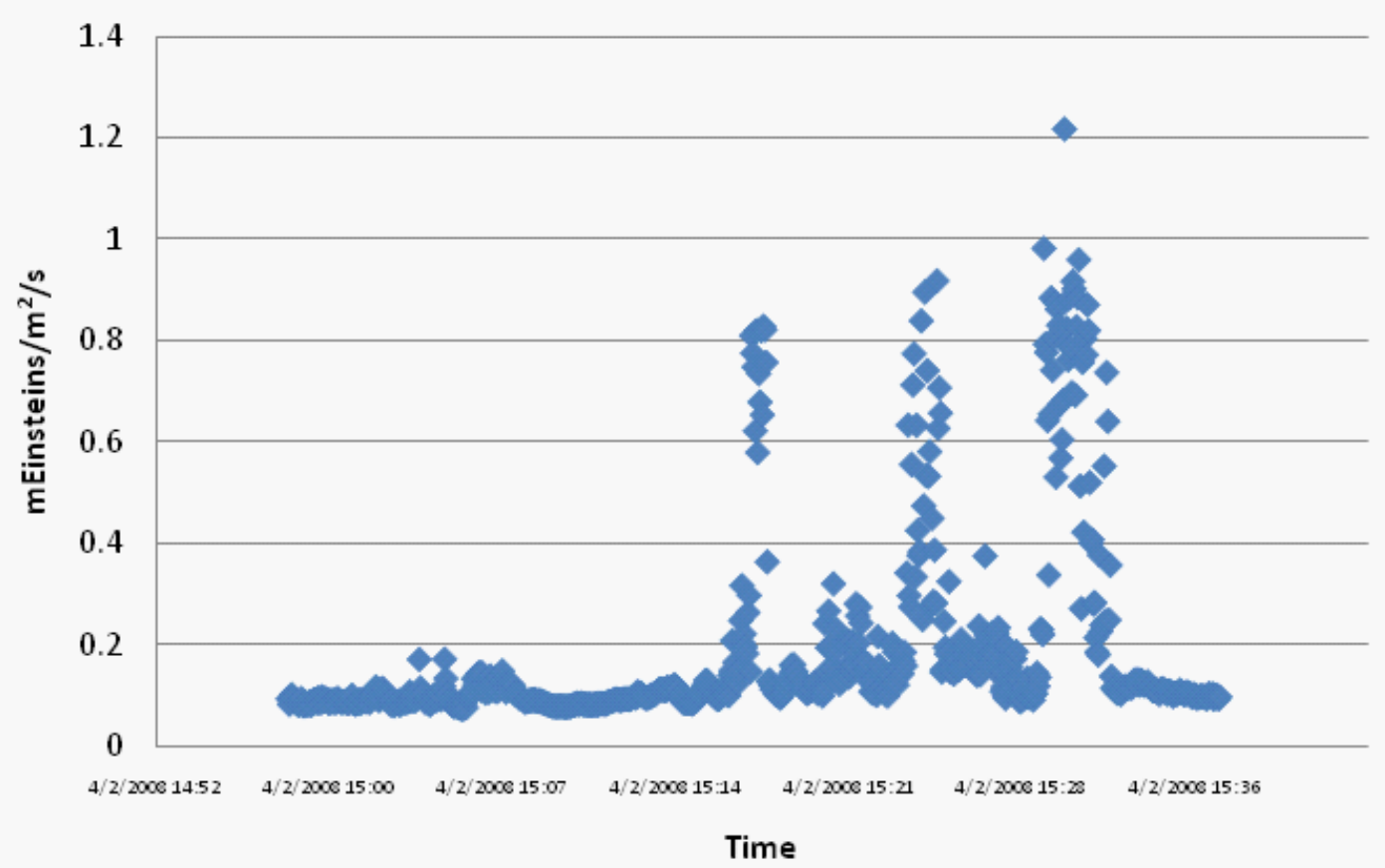

Figure 5.1.6: Variation of Photosynthetically Active Radiation (PAR) at Station 1 over one hour. 


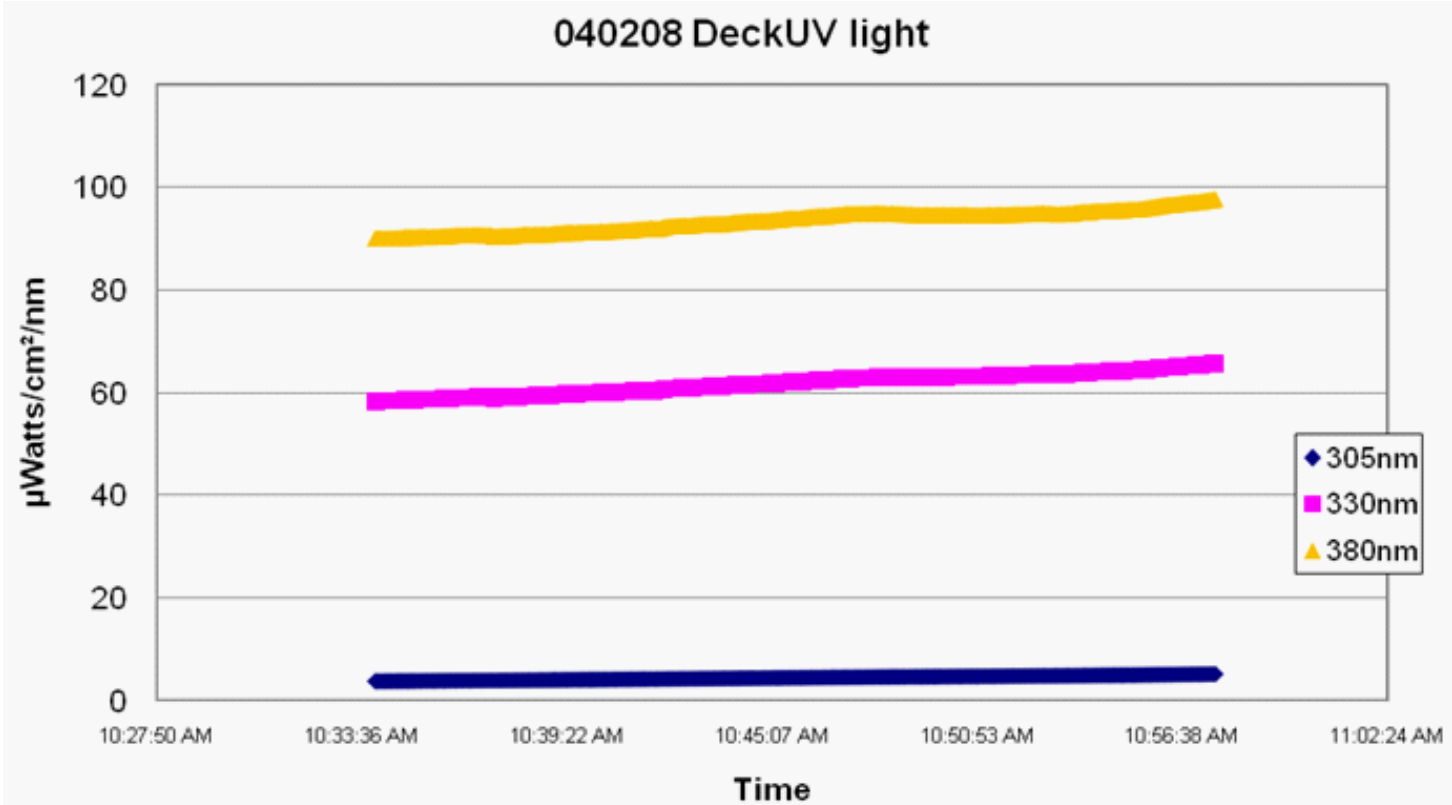

Figure 5.1.7: UV at 305,330 , and $380 \mathrm{~nm}$ on deck of vessel over approximately 30 minutes.

\section{Deck PAR 040108}

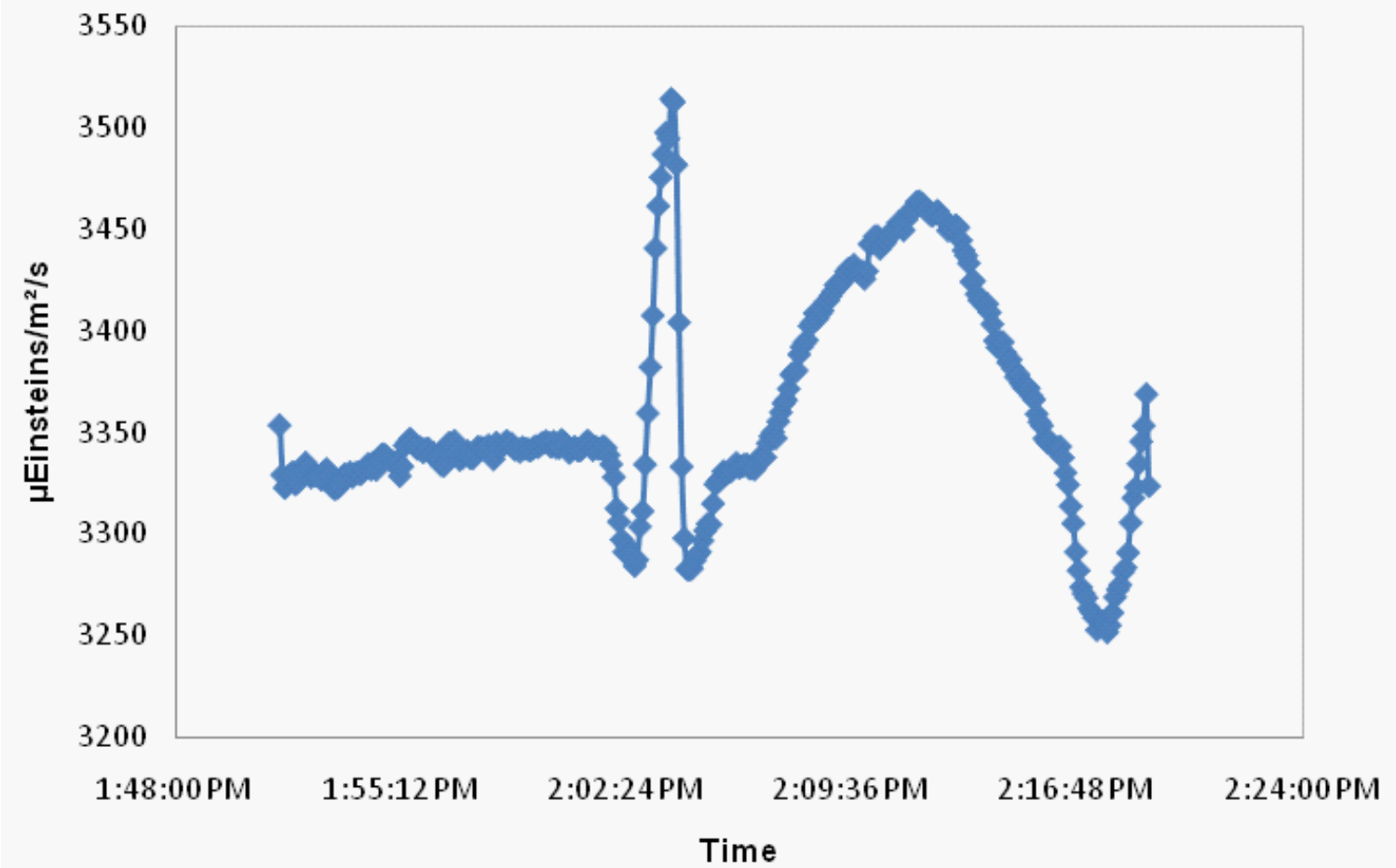

Figure 5.1.8: Photosynthetically Active Radiation (PAR) on deck of vessel over approximately 30 minutes. 
Publishing support provided by the Enterprise Publishing Network,

Ft. Lauderdale Publishing Service Center

For additional information, contact: Lisa L. Robbins, Senior Scientist U.S. Geological Survey

Coastal and Marine Research Center 600 4th Street South

St. Petersburg, FL 33701

(727) 803-8747, ext. 3005 Phone

(727) 803-2032 Fax 
